\title{
EDUCATIONAL POLICY CHANGE, NEWSPAPERS AND PUBLIC OPINION IN NEW ZEALAND, 1988-1999
}

\author{
Dorothy Ella Roulston
}

A thesis

submitted to Victoria University of Wellington

in fulfilment of the requirements for the degree of

Doctor of Philosophy

in Education

Victoria University of Wellington

2005 


\begin{abstract}
This thesis analyses educational trends as reported in five major New Zealand daily newspapers from 1988-1999 when the New Zealand education system underwent radical policy reforms.

Newspaper reporting of the educational reforms was set alongside and compared with a range of academic and professional critiques. The role of newspaper reporting differed from the academic literature in two inter-related ways. First, newspapers had to appeal to a 'reader audience' so as to achieve their second function, commercial viability. Commercial viability was achieved by a process of 'gatekeeping' whereby articles were selected for their publishing suitability. Gatekeeping took into account the reader audience, time constraints and the employer's political orientation. The key argument of this thesis was, that because of those restraints, reporting on complex educational issues, which required time to investigate, analyse, reflect and theorise, were too difficult and therefore, were largely ignored.
\end{abstract}

A mixed research methodology was used to identify the similarities and differences between academic and professional concerns with those educational articles found in newspapers. Five newspapers were surveyed over 12 years (1988-1999) on the basis of every 11 days, but omitting Sunday. This resulted in 1680 newspapers being identified. Educational articles were coded according to their story content and substory content and scored according to their prominence using the 'Budd Score' method.

The key findings were that articles about education, in the new global media market with its focus on the commodification of information, were superficial, narrow, unquestioning and given low priority. Such 'dumbing down’ was seen to have effectively muzzled the 'watchdog' role that the media claimed to have upheld. As a result a 'cultural bricolage' had led to an unequal power distribution that, based on the evidence of the literature review and the Budd score analysis in this thesis, was arguably anti-social, anti-Maori, anti-feminist, anti-competitive and therefore, anti-democratic. 


\section{ACKNOWLEDGEMENTS}

In the preparation of this thesis I have been frequently reminded of John Donne's well-known phrase "No man [or woman] is an island”. Many people have contributed to this thesis and without their invaluable help this thesis would not have been possible.

I owe considerable thanks to my supervisors, Associate Professor Kay Morris Matthews and Professor Cedric Hall, especially for their unstinting support, their sound critiquing, the generosity of their time, their humour and their unique inimitable selves. To you both, my warm and deepest thanks.

I would also like to express my gratitude and thanks to Victoria University's Faculty of Humanities and Social Sciences’ Research Committee for providing research grants that contributed towards meeting the cost of stationery associated with the thousands of survey sheets the research required. Also, for the grant that enabled me to attend the NZARE/AARE conference in Auckland to present a 'work in progress' paper. Such an experience was invaluable.

I have also been very fortunate and very privileged to be awarded one of the first 'PhD Completion Scholarships' by the Council of Victoria University. Such an award has been financially very beneficial in enabling me to complete my thesis. To the Council my very grateful and appreciative thanks.

I am also very appreciative for the help from the staff at Victoria University Library, and to Margaret Anderson, Victoria University’s School of Education’s librarian, who provided me with excellent support, assistance and camaraderie. I am also very grateful to the staff at the Turnbull Library and in particular to the staff in the Newspaper Room whose help and assistance was unstinting. Equally I am appreciative of the cost-effective pricing for the photocopying arrangement the Turnbull Library arranged for me. 
I thank Nick Bray, Jim Baltax, Andrew Robertson and Katie Nimmo in providing the technical assistance to use the SPSS10 computer programme when analysing the findings from the survey. Also I am indebted to the FHSS Research Committee for the loan of a laptop computer which enabled me to enter my data. I also thank Hilary Souter from the New Zealand Press Association who compiled the newspaper circulation figures from the Audit Bureau. Her skill in compiling the necessary information is much appreciated. My thanks also goes to educators and educationalists, James Irving, Jack Shallcrass, John Barrington, Ian Meredith and Richard Patterson (and his ghost writer) who were interested in the thesis topic and were happy to suggest helpful and useful advice.

Finally, I would like to express my thanks to my family, Neil, Paul, Alison and David, and my friends, Jean, Suzanne, Elizabeth and Bev, for their love, understanding and support during the lengthy journey. My deepest thanks to you all.

Dorothy Roulston 


\section{ABBREVIATIONS}

$\begin{array}{ll}\text { Appoints } & \text { Appointments } \\ \text { Bd Gov } & \text { Board of Governors } \\ \text { BOTS } & \text { Boards of Trustees } \\ \text { Coed/single } & \text { Coed/single institutions } \\ \text { CEO } & \text { Chief Executive Officer } \\ \text { CoE } & \text { Colleges of Education } \\ \text { Com asset } & \text { Community asset } \\ \text { Corp } & \text { Corporation or corporate body } \\ \text { Correspond } & \text { Correspondence School } \\ \text { Distance Ed } & \text { Distance Education } \\ \text { Ed Bd } & \text { Board of Education } \\ \text { Ed. Dept } & \text { Department of Education } \\ \text { Ed Forum } & \text { Education Forum } \\ \text { ECE } & \text { Early Childhood Education } \\ \text { ERO } & \text { Education Review Office } \\ \text { Govt gen } & \text { Government in general } \\ \text { Grad.tax } & \text { Graduate tax } \\ \text { Higher Ed } & \text { Higher education } \\ \text { INL } & \text { Independent Newspapers Limited } \\ \text { Learning/diffs } & \text { Learning/difficulties } \\ \text { Local Bods } & \text { Local Bodies } \\ \text { Non achiev } & \text { Non achievement } \\ \text { MPN } & \text { Main Page News } \\ \text { MoE } & \text { Ministry of Education/Minister of Education } \\ \text { MPs } & \text { National Qualifications Framework } \\ \text { NAGS } & \text { National Curriculum Framework } \\ \text { NCE } & \text { Nertiament } \\ \text { NEsment Guidelines }\end{array}$




$\begin{array}{ll}\text { Abbreviations Continued } \\ \text { NZBR } & \text { New Zealand Business Roundtable } \\ \text { NZEI } & \text { New Zealand Educational Institute } \\ \text { NZPA } & \text { New Zealand Press Association } \\ \text { NZQA } & \text { New Zealand Qualifications Authority } \\ \text { NZUSA } & \text { New Zealand University Students' Association } \\ \text { Obits } & \text { Obituaries } \\ \text { PCET } & \text { Post Compulsory Education and Training } \\ \text { PM } & \text { Prime Minister } \\ \text { PPP } & \text { Private-Public Partnership } \\ \text { PPTA } & \text { Post Primary Teachers' Association } \\ \text { Priv/Den } & \text { Private/Denominational } \\ \text { Salaries/conds. } & \text { Salaries/conditions } \\ \text { Sc. Cert } & \text { School Certificate } \\ \text { Self Dev } & \text { Self Development } \\ \text { SES } & \text { Socio-Economic Status } \\ \text { SOE } & \text { State Owned Enterprise } \\ \text { Spec. Schools } & \text { Special Schools } \\ \text { STA } & \text { Schools' Trustees Association } \\ \text { Stds } & \text { Standards } \\ \text { Teach. Method } & \text { Teaching Method } \\ \text { TINA } & \text { There is No Alternative } \\ \text { TRB } & \text { Teachers' Registration Board } \\ \text { Tr.Waitangi } & \text { Treaty of Waitangi } \\ \text { Under achieve } & \text { Under achievement } \\ \text { Un/equal opps } & \text { Unequalequal opportunities }\end{array}$




\section{CONTENTS}

ABSTRACT

ACKNOWLEDGMENTS ii

ABBREVIATIONS iv

LIST OF TABLES

\section{CHAPTER 1 - Introduction}

1.1 Introduction 1

1.2 Essential Arguments 1

1.3 Political and Economic Background 3

1.4 Policy Changes $\quad 5$

$\begin{array}{lll}1.5 & \text { Newspapers } & 9\end{array}$

$\begin{array}{lll}1.6 & \text { Reasons for this Study } & 10\end{array}$

$\begin{array}{lll}1.7 & \text { Chapter Outlines } & 13\end{array}$

CHAPTER 2 - Political and Economic Context: The Fiscal Crisis of the Welfare State

2.1 Introduction 16

2.2 Economic, Demographic and Unemployment Issues 16

2.3 The New Right 20

2.4 The Role of Treasury 22

2.5 The Fourth Labour Government 23

2.6 Summary and Conclusions 25

\section{CHAPTER 3 - The Education Reforms}

$\begin{array}{lll}3.1 & \text { Introduction } & 26\end{array}$

3.2 Criticisms of the Education Reforms 28

$\begin{array}{lll}3.3 & \text { Funding } 28\end{array}$

3.3.1 Primary, Intermediate and Secondary Schools 28

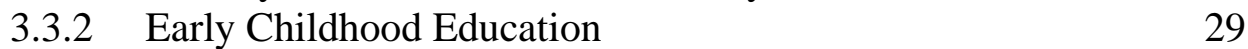

$\begin{array}{lll}\text { 3.3.3 Tertiary Education } & 30\end{array}$

3.3.4 Vouchers 33

3.3.5 Voluntary Fees 34

$\begin{array}{ll}3.4 & \text { Choice } \\ & 37\end{array}$

3.4.1 Zoning and Enrolment Schemes 37

3.4.2 Marketing an Image to remain Competitive 40

3.4.3 Illusionary Choice 42

3.5 Changing Teacher Roles, Relationships and Morale 42

3.5.1 Conflict between Teachers' and The New Right Ideologies 43

3.6 Curriculum, Assessment and Qualifications 45

3.6.1 Curriculum and Assessment 45

3.6.2 Unit Standards 46

3.6.3 The New Vocationalism and Criticism of Unit Standards 47 
3.6.4 The Role of the Education Review Office 48

3.6.5 Technocratic-Reductionist Market Model of Evaluating 51 Education

3.6.6 The Paradox of Curriculum, Assessment and 52 Qualification Reforms

3.7 Decentralisation, Devolution and Participation 53

3.7.1 The transfer of Power and Responsibility to Local 53 Administration

3.7.2 The Role of the Central Agency 54

3.7.3 Unresolved Conflict between Central-Local Agencies 57

3.8 Summary and Conclusions 58

CHAPTER 4 - Changing Patterns of Newspaper Reporting in New Zealand since the 1980s

4.1 Introduction 60

4.2 Ownership - changing patterns of the 80s 63

4.2.1 Ownership in New Zealand 63

4.2.2 Implications of Foreign Ownership 66

4.2.3 Implications of Cross-Media Ownership 66

4.3 The Role of the Media 68

4.3.1 Voice of the People $\quad 72$

$\begin{array}{lll}4.4 & \text { News Production } & 74\end{array}$

$\begin{array}{lll}\text { 4.4.1 Journalists } & 75\end{array}$

$\begin{array}{lll}4.4 .2 & \text { News Sources } & 78\end{array}$

4.5 Gatekeeping 80

4.5.1 Editorials and Letters $\quad 82$

4.6 Education Content in New Zealand Newspapers 84

$\begin{array}{lll}4.7 & \text { Summary and Conclusions } & 87\end{array}$

\section{CHAPTER 5 - Methodology}

5.1 Introduction 89

5.2. Two Major Research Paradigms $\quad 89$

5.2.1 Positivistic Approach 90

5.2.1.1 Criticisms of Positivism 90

$\begin{array}{lll}\text { 5.2.2 Anti-Positivism } & 91\end{array}$

5.2.2.1 Criticisms of Anti-Positivism 92

5.3 Mixed Method Approach 93

5.3.1 The Critical Theorists - Advocacy/ Participatory Knowledge 93 claims

5.3.2 The Pragmatist Knowledge claims 94

5.4 The use of Mixed Method Research Approach for this thesis 95

5.5 Phases of the Research 96

5.5.1 Selection of Newspapers 96

$\begin{array}{ll}\text { 5.5.2 Sampling of Dates } & 97\end{array}$

$\begin{array}{lll}\text { 5.5.3 The Budd Score } & 98\end{array}$

5.5.4 The Survey Sheet 99

$\begin{array}{lll}5.6 & \text { Validity } & 101\end{array}$ 
$\begin{array}{llr}5.7 & \text { Reliability } & 103\end{array}$

5.7.1 Pilot Study 103

5.7.2 Coding Recheck 104

5.8 Ethical Considerations 105

$\begin{array}{lll}5.9 \text { Summary } & 105\end{array}$

CHAPTER 6 - Results and Analyses from the Major Daily Newspapers Surveyed

$\begin{array}{lll}6.1 & \text { Introduction } & 107\end{array}$

6.2 Newspaper by Locality 107

6.2.1 Overview of newspaper by Locality 107

6.2.2 Newspaper by Newstype 109

6.2.3 Newspaper by Budd Score 113

6.3 Story Content Analysis 115

6.3.1 Newspaper and Story Content 115

$\begin{array}{lll}\text { 6.3.2 } & \text { Budd Score by Newstype } & 119\end{array}$

6.3.3 Story Content by Budd Score 121

6.4 Summary of Story Contents by Budd Score 125

CHAPTER 7 - Results and Analyses from Budd Score Four and Five Newspaper Articles

$\begin{array}{lll}7.1 & \text { Introduction } & 126\end{array}$

7.2 Overview of Budd Score Four Results 126

$\begin{array}{lll}\text { 7.2.1 Story Content } & 126\end{array}$

7.2.2 Newstype and Locality 127

$\begin{array}{lll}7.3 & \text { Story Content by Subcontent } & 127\end{array}$

$\begin{array}{lll}\text { 7.3.1 Story Content: Students } & 127\end{array}$

7.3.2 Story Content: Administration 131

7.3.3 Story Content: Institution 135

$\begin{array}{lll}\text { 7.3.4 Story Content: Staff } & 138\end{array}$

$\begin{array}{ll}\text { 7.3.5 Story Content: Finance } & 141\end{array}$

$\begin{array}{lll}\text { 7.3.6 Story Content: Curriculum } & 143\end{array}$

$\begin{array}{lll}\text { 7.3.7 } & \text { Story Content: Miscellaneous } & 144\end{array}$

7.3.8 Summary of the Analyses and Results from Budd Score Four 146

7.4 Introduction of Budd Score Five Results 147

$\begin{array}{lll}\text { 7.4.1 Overview of Budd Score Five Results } & 147\end{array}$

$\begin{array}{lll}\text { 7.4.2 Newstype and Locality } & 147\end{array}$

$\begin{array}{lll}\text { 7.5.1 Story Content: Student } & 148\end{array}$

7.5.2 Story Content: Administration 149

7.5.3 Story Content: Institution 151

7.5.4 Commercial Enterprise 151

$\begin{array}{lll}7.5 .5 & \text { Curriculum } & 152\end{array}$

7.5.6 General 152

7.6 Summary of the Analyses and Results from Budd Score Five 152 


\section{CHAPTER 8 - DISCUSSION: Part One}

8.1 Introduction 153

8.2 The Picot Reforms/Tomorrow’s Schools 1988-1999 153

8.3 Funding 160

$\begin{array}{lll}\text { 8.3.1 Tertiary Funding } & 160\end{array}$

8.3.2 The Role and Ownership of the Universities 169

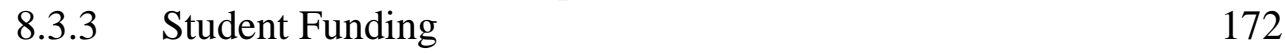

8.3.4 Primary and Secondary Schools’ Funding 178

8.3.5 Early Childhood Education 183

8.3.6 Commercial Enterprise 184

185

186

$\begin{array}{lll}8.4 & \text { Summary } & 188\end{array}$

\section{CHAPTER 9 - DISCUSSION: Part Two}

$\begin{array}{lll}9.1 & \text { Introduction } & 191\end{array}$

$\begin{array}{lll}\text { 9.1.2 Overview of Part Two } & 191\end{array}$

9.2 Teachers' Salaries and Employment Conditions 191

9.2.1 Bulk Funding 192

9.2.2 Teachers' Salaries and Employment Conditions 194

9.2.3 Recruitment, Resignations and Redundancies 196

9.3 Curriculum, Assessment and Qualifications 198

$\begin{array}{lll}\text { 9.3.1 Curriculum } & 198\end{array}$

9.3.1.1 Social Studies and Cultural Safety 199

9.3.1.2 English Curriculum 201

9.3.1.3 The New Vocationalism 203

9.3.2 Assessment and Qualifications 204

9.3.2.1 Attack on the Universities 205

9.3.2.2 General Criticism on Assessment and Qualifications 208

9.3.2.3 Educational Review Office 210

9.4 Access to Schools 212

9.5 The invisibility of Minority Groups 216

$\begin{array}{lll}9.6 & \text { Summary } & 218\end{array}$

\section{CHAPTER 10 - Summary and Conclusions}

10.1 Introduction 221

10.2 A brief overview of New Zealand Newspapers since the 1980s 221

10.3 Similar but not the same 222

10.3.1 Mirror Image $\quad 222$

10.3.2 Content Focus and Tone 223

10.3.3 Concepts 223

$\begin{array}{ll}\text { 10.3.4 Under-reported Themes } & 224\end{array}$

$\begin{array}{ll}\text { 10.3.5 Omissions } & 224\end{array}$

10.3.6 Differences within Newspapers $\quad 225$

10.3.7 The Wider Context 226

10.4 Communication, Complicated and Complex Theories 227

10.4.1 The Watchdog Role $\quad 229$

10.5 Summary, Conclusions and Recommendations 231 


\section{APPENDICES}

A Newspaper Survey Sheets (A.5.1-A.5.6) 247

B Table. A.7.1: Summary by Newspapers of Story Contents and 253 Subcontents with a Budd Score 4, giving their newstype and locality: 1988

C Table.A.7.2: Summary by Newspapers of Story Contents and 254 Subcontents with a Budd Score 4, giving their newstype and locality: 1989

D Table.A.7.3: Summary of Newspapers of Story Contents and Subcontents with a Budd Score 4, giving their newstype and locality: 1990

E Table.A.7.4: Summary by Newspapers of Story Contents and Subcontents with a Budd Score 4, giving their newstype and locality: 1991

F Table. A.7.5: Summary by Newspapers of Story Contents and Subcontents with a Budd Score 4, giving their newstype and locality: 1992

G Table.A.7.6: Summary by Newspapers of Story Contents and Subcontents with a Budd Score 4, giving their newstype and locality: 1993

H Table. A.7.7: Summary by Newspapers of Story Contents and Subcontents with a Budd Score 4, giving their newstype and locality: 1994

I Table.A.7.8: Summary by Newspapers of Story Contents and Subcontents with a Budd Score 4, giving their newstype and locality: 1995

J Table.A.7.9: Summary by Newspapers of Story Contents and Subcontents with a Budd Score 4, giving their newstype and locality: 1996

K Table. A.7.10: Summary by Newspapers of Story Contents and Subcontents with a Budd Score 4, giving their newstype and locality: 1997

L Table.A.7.11: Summary by Newspapers of Story Contents and Subcontents with a Budd Score 4, giving their newstype and locality: 1998

M Table. A.7.12: Summary by Newspapers of Story Contents and Subcontents with a Budd Score 4, giving their newstype and locality: 1999

N Table.A.7.13: Summary by Newspapers of Story Contents and Subcontents with a Budd Score 5, giving their newstype and locality: 1982-1992

O Table. A.7.14: Summary by Newspapers of Story Contents and Subcontents with a Budd Score 5, giving their newstype and locality: 1993-1999 


\section{LIST OF TABLES AND FIGURES}

\section{CHAPTER 3 - The Education Reforms}

3.1 Education Reforms and Policies 1988-1993

CHAPTER 6 - Results and Analyses from the Major daily Newspapers Surveyed

6.2.1 Summary of all Newspapers giving their Locality distribution: 108 1988-1999

6.2.2 Summary of all Newspapers giving their Newstype: 1988-1999 110

6.2.3 Summary of all Newspapers by Budd Score: 1988-1999 113

6.3.1 Summary of Newspapers by Story Content: 1988-1999 116

6.3.2 Summary of Budd Score by Newstype: 1988-1999 122

6.3.3 Summary of Story Content by Budd Score: 1988-1999 123

CHAPTER 10 - Summary, Conclusions and Recommendations

10.4 Summary of the Similarities and Differences between Academic 229 and Professional Literature and Newspaper Articles 


\section{CHAPTER ONE - INTRODUCTION}

\subsection{Introduction}

This thesis is about the educational trends as reported in five major New Zealand daily newspapers from 1988-1999 when the New Zealand education system underwent radical policy reform. Specifically, this thesis poses two questions. First, did the newspapers reflect the same issues as the critiques of education policy changes written by academic and professional groups? Second, did the public receive from newspapers the kind of coverage and analysis that would help them realise the significance of the education policy changes taking place?

This chapter will give an introduction to some of the ideas this thesis covers under the following headings:

- Essential arguments

- Political and economic background

- Policy changes

- Newspapers

- Reasons for this study

- Chapter outlines

Note: Cross-referencing to sections of the thesis are made in the following format: "see 4.6”. In this example, the cross-reference refers to chapter four, section 6 .

\subsection{Essential Arguments}

This thesis has two essential arguments. First, while both academic and professional writers and newspapers see their roles as being a 'critic and conscience' of society, the role of newspaper reporting differs in two interrelated ways. The first is that newspapers achieve commercial viability through a system of 'gatekeeping'. Lewin (VUW Political Science paper, 1984:162) describes the gatekeeper's role as being where: 
Gate sections are governed either by impartial rules or by "gatekeepers"; and in the latter case an individual or group is "in power" for making the decisions between "in" and "out".

Selecting what is newsworthy is made through a complex series of decisions. Central to what is selected 'in' or 'out' are the political orientations of the employers and owners of the newspapers. Four of the five major New Zealand daily newspapers surveyed for this thesis were owned and controlled by two international conglomerates, Murdoch and O’Reilly. Both are well known for their neo-liberal political orientations (Kelsey, 1999; see 4.2.1). Such 'duopolies', according to media commentators Norris (2002), McGregor (2002) and Perigo (2002), have a detrimental effect on the influence of newspaper production in New Zealand and will be explained further in chapter four, particularly in sections $4.2 .1 ; 4.2 .2 ; 4.2 .3 ; 4.3$ and 4.3.1.

The second argument is that in the period 1988-1999 major education policy changes was largely under-reported in New Zealand newspapers. This thesis argues that, in order to fulfil their dual functions of attracting a reader audience so as to remain commercially viable, newspapers relied on local, sensational, highly descriptive, human-interest, eye-grabbing stories. These usually occupied highly prominent positions on and within newspaper pages. Such prominence indicated that these articles were highly newsworthy. In comparison, the 6,166 articles this thesis surveyed on education were overwhelmingly unsensational and were not prominently positioned on or within newspaper pages. Indeed, this thesis argues that educational articles reported in New Zealand newspapers were seldom contentious because, if they were, they would run the risk of offending the reader audience and, in turn, compromise their commercial viability.

A third argument is that issues about education are more 'complex' than is able to be communicated through the newspaper and will be discussed in chapter ten. 
Consequently, while newspapers claimed to uphold the role of 'watchdog', this cannot be claimed for the coverage of significant educational policies in New Zealand. Therefore, this thesis argues that the reading audiences of the five major newspapers during this period were exposed to a narrow and superficial coverage of some of the issues arising from the radical education policy changes.

\subsection{Political and Economic Background}

The background to New Zealand politics, prior to the radical policy changes of the late 1980s, is crucial to understanding why the fourth Labour Government sought to introduce such changes to the education system in 1988. In sharp contrast to the groundbreaking interventionist social welfare policies of the first Labour Government to address issues of social inequality, which provided assistance to those unable to provide for themselves, the fourth Labour Government's radical change in philosophy sought to revive the central tenets of classical economic liberalism with 'laissez-faire' (hands-off) policies (see 2.3).

From the 1970s, New Zealand had experienced a series of economic crises, which were seen by many as serious weaknesses in the welfare state model. By the early 1980s the concern increased further with the continued decline in the Gross National Product and, despite subsidised creative work schemes, there remained high numbers of unemployed (Shuker, 1987; see 2.2).

Associated with the failing economic system and the intractable unemployment rate were criticisms of the welfare state itself. During the later National Government years, 1982-1984, when the Prime Minister, Sir Robert Muldoon, held the portfolio of Finance, Treasury, according to Douglas (cited in Butterworth and Butterworth, 1998:35), "had plenty of time to think." Treasury's thinking led them to believe that there was a need to restructure the entire economy. They proposed new policies and criticised the old policies, including the existing social welfare policies. Treasury believed that 'capture' by consumers, providers (such as teachers) and state administration agents had advanced their own causes at the expense of those truly in need. As a result, the 
fiscal crisis had been exacerbated by an over-burdened welfare state and so change was advocated (see 2.4).

To resolve the fiscal crisis Treasury, in 1987, produced its second volume of “Government Management”. The report was subtitled “Education Issues” and reflected the importance of the role of education to overcoming the economic crisis (see 2.4). Not all were accepting of Treasury's proposals, for example Snook (1989:12) thought that, “Treasury confidently saw itself as the expert not only in the economy but on everything else as well." However, such comments were largely ignored.

Outside government, prominent businessmen, such as Roger Kerr, the National Executive Director of The Business Roundtable, supported the view that the welfare state 'wasted time’ and 'destroyed families' (Boston, 1999:4). While such comments could be expected from such a well-known 'right wing' political advocate, other more 'left-wing' groups, including some trade unions, and the media began to adopt a similar stance. So unusual was it for political groups and the media to see eye-to-eye that Grace (cited in Codd, 1990a: 17) referred to this collective as 'The unholy allies'.

The unholy allies, however, had additional support from many disaffected new middle class voters keen to see economic change. It had been this group who had helped to elect the fourth Labour Government into power. What they wanted was increased government accountability, efficiency and management procedures (Boston and Holland, 1987; see 2.2).

Such radical philosophical and political views were consistent with of the central tenets of Adam Smith's 'classical liberalism' in which the government played a 'laissez-faire' role. However, 'neo-liberalism', in its many forms, was significantly different from classical liberalism in its concept of power (other differences will be explained more fully in chapter two). Classical liberalism was characterised by representing 'negative' power where the individual was 'free from' the intervention of the State (Jesson, 1987; Apple, 2001; Marshal et al, 2000; see 2.3). In contrast, neo-liberalism was characterised by representing 
'positive' power where the government set the conditions in which the individual was 'free to' operate, so long as it was within those conditions (Olssen and Morris Matthews, 1997; see 2.3). By adopting the philosophical tenets of neo-liberalism, the Labour Government had moved from its traditional stance of socialism to a moderate form of liberalism. In turn, this enabled the redistribution of wealth, under the guise of freedom of choice, fairness and equity, to flow to the rich thus providing the security that the welfare state had failed to provide (see 2.3).

\subsection{Policy Changes}

With the support from Treasury, the unholy allies and many middle class voters the Labour Government was able to use their consensus to legitimate the restructuring of the central agency services using what were now referred to as 'new right' policies. From 1984 the Labour Government introduced sweeping policy changes across all state sectors. These wide spreading policy changes included, for example, health policy, public policy, economic policy, monetary and exchange rate policies. Collectively, these new policy changes were known as the 'new public management' policies (NPM).

To meet these changes meant an overhaul in the public administrative sector, which included the education system. The education system too fell under the new public management policies to meet the demands of efficiency, accountability, quality and choice characteristic of the neo-liberal market philosophy (see 2.3). Despite education being seen as a 'public good' (see 3.3.3) for a 'decent life' (see 3.1), Treasury's view of education was that it was costing the Government too much and that streamlining across all sectors was required. In order to streamline the education sectors a series of reports were commissioned.

From 1988 a raft of educational reports and policies were produced by and for the Labour Government. In particular, The Report of the Early Childhood Care and Education Working Group (known as 'The Meade Report'), Administering For Excellence (known as 'The Picot Report', 1988), Tomorrow's Schools (1988) and, Education and Training (known as 'The Hawke Report', 1988) 
made recommendations for administrative reform of early childhood, primary, secondary schools and tertiary levels in education.

While the four reports differed in detail, and in the extent of the changes they recommended, they had much in common. These included ways that control of education could be transferred from state and regional control to the control of locally elected community boards, that employment of staff could be transferred to the local boards, and the management of property and assets could be placed in the hands of institutions.

A second feature was the increase in consumer choice (see 3.4 and 3.4.1) where parents and students (now consumers) could choose their preferred educational institution. In response to this increased consumer driven economy, schools (providers) were expected to become competitive (see 3.4.1 and 3.4.2) and entrepreneurial (see 3.4.2) in selling their services (products) to consumers who bought education on a 'user-pays' basis (see all sections in 3.3).

A third feature related to performance. The providers of educational services were to be measured, that is accountable, through a variety of assessments (see 3.5; 3.6; 3.6.2 and 3.6.4). Primary schools, for example, were to be measured by the school charters that each school had written for its own use. Furthermore,"new management incentives were initiated to adopt efficient business practices" (Lauder, cited in Peters and Marshall, 1996:68), in the interests of accountability and fiscal responsibility (see 3.5 and all sections in 3.6).

The educational ideology based on the social welfare model (see 3.1) had changed to a private, competitive, commodity in line with the 'new right' philosophy of the market economy. These principles of the 'new right' were enacted, via legislation, under the Education Act 1990. The social welfare model that the first Labour Government instigated 50 years before had been replaced with its antithesis by the fourth Labour Government. The implementation of the administrative changes in education became known as 
'the education reforms' or, 'the reforms' if referred to in an educational context. It is in this context that this thesis uses such terminology.

The education reforms very quickly raised criticisms from academic and professional writers. Grace (cited in Holland and Boston, 1992; see 3.1) believed that the neo-liberal ideological changes had seriously compromised the egalitarian principles that the state education system had upheld for 50 years. Olssen and Morris Matthews (1997:19) believed that with the loss of such principles education was becoming a "private commodity subject to market forces.” In other words, education had become something for sale, that could be bought in a competitive market, by any individual who had the money to pay for it; and new terminologies such as user-pays, the commodification of education, privatisation of education and market forces, emerged to reflect those changes.

However, while it was clear that market forces were to influence the education system, less clear was the division between local and central management. Terms such as 'devolution' (where there is transfer of power to the local region) or 'decentralisation' (where transfer of responsibility is given to local management) were used interchangeably thus creating confusion (see 3.7 and 3.7.1). David Lange, the Labour Government's Prime Minister and Minister of Education, who oversaw the reforms, provided a graphic illustration when he says:

Tomorrow's schools accepted that local management was desirable. But the local school could flourish only if it based its programmes on national standards. I used, when promoting the reforms, to tell people that they could be as democratic as they liked, once they acknowledged the Government's authority to determine the curriculum and the standards of the teaching profession, and its right to examine the performance of the school in the interests of the children (Lange, 1994:88). 
With the lack of clarity the tension and conflict between the central and local authorities emerged and remained to pervade, either directly or indirectly, all sectors of the education system. As early as 1991, Codd and Gordon (see 3.7.2) saw a paradox where the state had actually increased its regulatory power while at the same time the state had distanced itself from civil society. In other words, the government was seen to have decentralised its responsibility while at the same time retaining and increasing its control over educational institutions.

Later, Barrington (1998; see 3.7.2) highlighted the subtle ways in which power and control was recentralised. For example, by disestablishing the Parents' Advocacy Board the parents were deprived of direct access to the Minister of Education and, as a result, the parents lost their 'voice'.

Other government policy changes that impacted on the autonomy of the schools were the introduction of the New Zealand Curriculum Framework, the revised National Educational Guidelines, the establishing of the Education Review Office, and the New Zealand Qualifications Authority. Such changes were seen to be returning the power and control to the central agencies (see 3.7.2).

Further tensions arose over funding, for example, between education that was state funded and education that was privately or voluntarily funded (see 3.3.4 and 3.3.5). Other tensions arose between the state and minority groups. Maori, for example, thought the State failed to enable Maori to develop and maintain their own culture as a democratic right (see 3.7.2).

Other critiques of the administrative changes in education will be discussed in chapter three under specific topics. Underpinning the academic and professional literature was the belief that the education reforms, based on neoliberal philosophy, were iniquitous because it denied many groups, particularly minority groups, access to a decent education to fulfil their potential and to take their place in society. Consequently, the education reforms were 
considered by some academic and professional writers to be anti-social, antifeminist, anti-Maori and, therefore, anti-democratic.

\subsection{Newspapers}

Coinciding with the introduction of the new public management policies was a change in ownership of New Zealand newspapers. In the early 1980s, when the Labour Government commenced its 'laissez-faire' policies and deregulation laws on foreign ownership, New Zealand newspapers changed hands from New Zealand family owned businesses to becoming owned and dominated by two foreign conglomerates.

Of the duopolies Independent Newspapers Limited (INL), owned by Robert Murdoch, controlled most of the major daily newspapers including, The Evening Post (Wellington), The Press (Christchurch) and The Southland Times (Invercargill). The second owner, Wilson and Horton, published The New Zealand Herald and by 1998 was 100 per cent owned by interests associated with the Irish media mogul Tony O’Reilly, owner of Independent News and Media. Collectively, Kelsey (1999:195) estimated Murdoch and O’Reilly owned 92 per cent of the metropolitan newspaper market and 81 per cent of the provincial newspaper market.

In addition to the print media, Murdoch and O'Reilly had international ownership and control of other media services in radio and television. Such 'globalisation' of media services in private hands was seen to have several negative implications for New Zealand's media services. Critics, such as Norris (2002; see 4.2.1; 4.2.2; 4.2.3 and 4.3), believed that New Zealand's national identity and culture was lost because news was based on economies of scale and, through instant communication, could be transmitted globally from an overseas source in preference to a New Zealand source.

Norris (2002; see 4.2.3) argued that the profit made in New Zealand was going overseas and therefore, the money was not being reinvested into New Zealand. He believed those newspapers, as well as other media sources, were only for 
commercial profit and capital growth for overseas interests, which ultimately impoverished New Zealand.

As a consequence of global foreign ownership, the newspaper role of watchdog was seen by critics to have become muzzled. Such muzzling came about through a series of complex implicit and explicit gatekeeping controls (see 4.5). The critical analysis theorist, Jurgen Habermas, provides a useful analysis. According to Habermas (1984; 1987; 1989; 1992; 1996; see 4.1), the outcome of such gatekeeping controls means that the reader audience is not well informed of relevant issues. The lack of information denies the public an opportunity to debate issues that could lead to rational and just outcomes. The relevance is that globalisation of newspapers by foreign ownership is seen to fail by being anti-democratic and is anti-competitive, which paradoxically, is contrary to neo-liberal philosophy.

\subsection{Reasons for this Study}

Although newspapers view their role as 'watchdog' of social issues, others, such as Curran (2000; see 4.3.1) and Curran and Seaton (1988; see 4.3), have argued that this role has been muzzled because of the complex gatekeeping controls that determine what is 'selected in' or 'selected out' of what is published. Despite such criticisms however, Norris (2002:47-48) notes:

Little, if any, analysis has been done on the changes in content within New Zealand newspapers since the 1980s consolidation began in earnest.

This is also true of newspaper reporting on the New Zealand education reforms and the ten years thereafter. During this time many refinements were made by successive governments to the four 1988 founding reports (see Figure 3.1). This thesis raises two questions in relation to the reporting of the education reforms and the issues arising from them. In particular, the questions posed were to identify to what extent educational issues were raised in the five major daily New Zealand newspapers. What, if any, were the similarities and differences between newspaper story contents, especially in terms of analysis 
and coverage, compared with those covered in academic and professional literature? Did New Zealand newspapers reflect the same issues as the critiques of education policy changes written by academic and professional writers? Did the public receive from newspapers the kind of coverage and analysis that would help them realise the significance of the education policy changes taking place?

An extensive overseas literature search found only two studies concerning the content analysis of newspapers covering education reforms during this period and both were from the United States of America.

Kim (1989; see 4.6) found that the extent of newspaper coverage in five major daily newspapers in Connecticut differed substantially in terms of quality and quantity with much of the news about the education reforms focusing on financing public schools, and was event orientated rather than issue orientated. Consequently, the wider implications of the education reforms eluded the public because of the narrow range of story content that was generally reported by entry level journalists who had neither the expertise nor experience to investigate the serious issues.

Bowers (1988; see 4.6) examined the education reforms in Texas and concluded that the media quoted more frequently and favourably those who supported the reforms. Conversely, those who were critical of the reforms received harsher treatment in the media.

In New Zealand, two studies on content analysis of New Zealand newspapers relating to education were found. Cleveland's (1971:13; see 4.5 and 5.6) study found that items about education represented only 1.8 per cent of all news articles and were predominantly local, unsensational, consensual and had low priority.

Similarly, Roulston (1986; see 4.5 and 5.6) found that educational articles had historically low prominence, low status and were more likely to be consensual rather than sensational. However, Roulston found that in the earlier period 
surveyed, 1901-1905, when New Zealand's education system underwent radical change, the 'hot-topics' that received the most prominence were the 'administration' and 'syllabus' story contents. In sharp contrast, the latter period, 1978-1982, revealed a move toward 'pupil' story contents, especially where the focus was on health and learning difficulties.

Some academic writers have referred to the content of some New Zealand newspapers' reporting when discussing the education reforms. For example, Barrington (1990; see 4.6) saw the media as paving the way for the acceptance of the reforms based on fear that the current education system was failing school leavers, particularly Maori, which would lead to "increasing disaffection by many Maori” (Barrington, 1990:199). Barrington believed that such a suggestion implied that the fear of civil and racial unrest could follow.

On a different note, Codd (1990b: 201) viewed the media's reporting of the Picot reforms as a highly managed campaign where, "teachers and the public were 'persuaded' by a skilfully orchestrated media presentation that the major Picot proposals were both necessary and beneficial." Similarly, Grace (cited in Codd, 1990a: 17) thought the unholy allies were challenging the first Labour Government's principles of state education, which had served the country well for 50 years. Thus these three academic writers saw the media supporting neoliberal policies, which influenced the government's response to the pressure that the media put it under.

Ramsay (1993; see 4.6), who had been a member of the Picot Committee, had a different perspective. Ramsay maintained that the public had been fed a 'diet of negativity' throughout the eighteen months when the Picot Report was initiated. But, despite the negative media reports, Ramsay (1993: 270) believed, "the fears covering the education reforms would be unfulfilled."

Later criticism about newspaper reporting on educational issues came from two main sources and both focused on the media's negative portrayal of the teaching profession (see 4.6). For example, Sullivan (1999:144) believed that, "teachers had taken a battering from both the press and by the slow inexorable 
build-up of anti-teacher legislation and regulations which inherently deny their status as professionals.”

Thrupp and Smith (1999; see 4.6) shared a similar view. They wrote about the delegitimisation of the teachers' professional role that was taking place in the way in which the media published the Education Review Office reports on schools. Thrupp and Smith believed that such publications indirectly undermined the teachers' professional role. Furthermore, such newspaper publications served a simultaneous dual role. First, by warning other schools to 'shape up' and second, by shaping consumer, that is, public opinion.

Therefore, although academic and professional writers have expressed some mixed views about the media's reporting on the education reforms, there has been no specific study of the content analysis on such issues per se.

Academic and professional literature has identified serious issues arising from the education reforms. This raises the question whether or not the newspapers, in their role of watchdog, have brought these issues to the attention of the reader audience (that is, the public), so that the public can debate and, ultimately, make rational and just decisions, which is an expectation within a democratic society. It is for these reasons that this thesis sets out to answer the questions posed at the beginning of this chapter.

\subsection{Chapter Outlines}

The remaining chapters of this thesis are structured as follows:

Chapter Two - Political and Economic Context: The fiscal crisis of the Welfare State: gives a brief outline the fiscal crisis of the welfare state in New Zealand, which led to the political, economic and philosophical changes toward neo-liberalism, and ultimately to the changes in eduction administration policy.

Chapter Three - The Education Reforms: discusses the criticisms arising from the education reforms that were identified by academic and professional writers. In particular, the criticisms highlight the paradoxical, contradictory and 
unethical tensions between educational ideology on the one side and neoliberal ideology on the other.

\section{Chapter Four - Changing Patterns of Newspaper Reporting in New} Zealand since the 1980s and their Implications: considers the implications arising from the changing role of ownership during the 1980s when, under the new deregulation laws, New Zealand family owned newspaper industries were sold to overseas foreign global media moguls. Such ownership was seen to increase the globalisation, privatisation and commercialisation of all news services. Critics saw the content of newspapers, by a complex method of gatekeeping influences, being muzzled and 'dumbed down'. As a consequence, critics argued that the media had failed in the watchdog role it purported to have and therefore, undermined the fundamental tenets of a democratic society.

Chapter Five - Methodology: covers the rationale for using a mixed research methodology, which provides a flexible paradigm in the choice of methods, techniques and procedures that are best suited to the purposes of this study. In particular this chapter describes the use of a prominence index, known as a Budd score, which quantitatively measures what editors believe to be 'newsworthy' for their newspapers.

\section{Chapter Six - Results and Analyses from the Five Major Daily} Newspapers: is a descriptive chapter that presents the statistical results and analyses findings from the five newspapers surveyed. Specifically, this chapter covers two comparative analyses. The first compares the emphasis newspapers give to locality of story (local, national and international), the newstype (editorial, main page) and the Budd score (prominence index of each article). The second comparative analysis covers the story content in which the articles are analysed in respect of newspaper and story content, newstype and Budd score, and story content and Budd score.

\section{Chapter Seven - Results and Analyses from Budd Score Four and Five} Newspaper Articles: presents the findings from the five major daily newspapers that had a high Budd score (four or five). Specifically, this chapter 
focuses on the story contents, the substory contents and, where relevant, the newstype and locality.

Chapter Eight - Discussion: Part One: discusses the most dominant story content topic, finance, including its associated substory contents, and compares newspaper treatment with the critiques of academic and professional writers.

Chapter Nine - Discussion: Part Two: covers the remaining dominant Budd score story contents, and also compares the newspapers' treatment with those of academic and professional writers.

Chapter Ten - Summary and Conclusions: addresses the two questions raised in this thesis using two theories. The first is based on Habermas's critical analysis theory, while the second uses 'Complexity' theory (Davies et al, 2000; Humphreys and Hyland, 2002). Finally, this chapter draws conclusions in respect of the two questions posed in this thesis. 


\section{CHAPTER TWO - THE POLITICAL AND ECONOMIC CONTEXT: THE FISCAL CRISIS OF THE WELFARE STATE}

\subsection{Introduction}

This chapter discusses the fiscal crises of the welfare state in New Zealand, which in turn led to the political, economic and educational reforms during the late 1980s and the early 1990s. Specifically, this chapter will cover:

- Economic, demographic and unemployment issues - their contribution to the fiscal crisis

- The New Right

- The role of Treasury

- The fourth Labour Government - who introduced and oversaw the 'new right' policies, and

- Summary and conclusions concerning the changes that contributed to the administrative reforms in education

\subsection{Economic, Demographic and Unemployment Issues}

In keeping with many other Western countries, New Zealand's economic difficulties began to emerge in the early 1970s when export prices slumped and New Zealand's economy became part of the international recession. Since the 1970s there had been increasing interdependence of global economic, political and social relationships. A change in one part of the world had had an effect on New Zealand's infrastructure. The oil shocks of the early 1970s, for example, led to car-less days, and a search for alternative new energy sources. The 'Think Big' programmes that resulted from the oil crisis led to major structural changes including the implementation of comprehensive, mandatory control on prices, wages and interest rates.

Boston and Holland (1987: 3) describe the economic situation of that time as follows: 
Coupled with the advocacy of an activist state was a quest for economic stability, security and certainty. [To meet these demands at the macroeconomic level Keynesian type management had been used.] Such policies supported guaranteed prices for agricultural commodities, various kinds of subsidies and incentives to the export sector, the maintenance of a substantial level of border protection for domestic manufacturing, the tight control on capital markets, strict limits on foreign ownership, and a highly regulated labour market.

At the microeconomic level there was an accompanying state regulation "that was highly detailed and often ad hoc to support them” (Boston and Holland, 1987: 3). During the 1970s these policies began to fail. To illustrate the depth of recession Freeman-Moir (cited in Shuker, 1987: 65-66) used the following two indices:

1. Real GDP (a measure of the relative level of the volume of production in each year) declined dramatically between 1974 and 1981, to be well below the levels achieved in the 1960s and early 1970s.

2. Employment, as measured by the number of job vacancies, showed a marked decline after the mid 1970s. Consequently, the number of unemployed or on temporary work schemes increased, particularly in the period 1977-1982. Furthermore, there was an increase in those who left the country on either permanent or long term basis.

Although the newly elected Labour Government in 1984 had "Managed to reduce the numbers of people either registered as unemployed or on subsidised schemes, unemployment ran at 3.8 per cent. There were 16,842 people on partly subsidised job creation schemes and 20,720 on fully subsidised schemes” (Shuker, 1987: 66).

Associated with the failing economic system, and its intractable unemployment rate, came criticism of the welfare state, in particular from the Business 
Roundtable and from New Zealand Treasury. Boston (1999: 4) itemises the main criticisms made of the welfare state, which had:

- Failed to reduce poverty or overcome disadvantage

- Provided disproportionate assistance to those who need it least

- Encouraged dependency on welfare benefits

- Promoted 'provider capture' (explained later) and generated large, insensitive and inflexible bureaucracies

- Undermined the traditional family unit

- Displaced private and voluntary welfare

- Undermined personal responsibility and

- Created perverse incentives, thereby discouraging employment and undermining growth.

With the changing economic conditions was a corresponding political philosophical change, particularly within the Labour Party. From the 1970s the Labour Party had changed its principles of social justice from being based on entitlements to one based on 'the principle of fairness in the John Rawls' sense” (Palmer cited in Boston and Holland, 1987: 20). Palmer also advocated Rawls' notion of the 'Difference Principle' where:

Liberty, wealth, income and opportunity ought to be distributed equally unless it can be clearly demonstrated that unequal distribution will benefit the least advantaged (Boston and Holland, 1987: 21).

Coupled with this notion was 'participatory democracy' where there would be "greater access to information rather than the power to initiate, except at local level” (Boston and Holland, 1987: 21). Furthermore, "Palmer believed in the concept of 'freedom' but in the negative sense of freedom from, rather than freedom to do" (Boston and Holland, 1987: 21). According to Palmer "the essence of freedom is the protection of the individual against both public and private power" (Boston and Holland, 1987: 21). In short, there had been a conceptual move from socialism to a moderate version of liberalism. 
Accompanying this conceptual change was the concept of 'economic efficiency’. Efficiency meant increased prosperity. Increased prosperity would mean that, "the redistribution of wealth could take place in accordance with the principles of equity and fairness without requiring a major transfer of resources from the rich to the poor” (Boston and Holland, 1987: 21). Boston and Holland (1987: 23) attribute many of these changes to the demographic transformation in which there was:

A relative decline in the "old middle class" of higher professionals, businessmen and farmers (from 21\% in 1911, to 9\% 1976); and the relative increase of the "new middle class" of lower professionals, sales, managerial and clerical workers (from 19\% to 41\%).

It was this group who supported Labour's new philosophy. In addition, trade unionists were also aware of New Zealand's economic predicament and some became supportive of the new changes. Well-known trade unionist Rob Campbell wrote a foreword in Roger Douglas's book “Toward Prosperity”. Campbell (1987: 8) concluded:

A lot of negative things have been done and now options do begin to open up to the kinds of things New Zealanders can do as individuals, as communities and as a Government. The real danger now is not what lies ahead of us but what lies behind, and those who hanker to return there.

A combination of political and economic elites, supported by a new middle class, led to a new hegemonic order intent on modernising the economy that was to provide security, which the welfare state had failed to do. With restricted resources, in terms of money and power, the new middle class, whose advancement, relied on accountability, efficiency and management procedures, now became the dominant group with its own cultural capital. Barbara Ehrenreich observes (cited in Trotter, 2002:14):

If this is an elite, then it is an insecure and deeply anxious one. It is afraid, like any class below the most securely wealthy, of 
misfortunes that might lead to a downward slide. But in the middle class there is another fear; a fear of inner weakness, of growing soft, of failing to strive, of losing discipline and will. Even the affluence that is often the goal of all this striving becomes a threat, for it holds out the possibility of hedonism and self indulgence. Whether the middle class looks down towards the realm of less, or up towards the realm of more, there is the fear, always, of falling.

With those fears and the need for security the 'common good', once based on freedom and equality, changed from no longer being democratic as of right but based on commercial values. The rules of the game had changed to being "antagonistic rather than complementary" (Apple, cited in Lingard et al, 1993:56) in sharing the limited resources and leaving out the hard fought rights of minority groups, for example women and ethnic cultures.

\subsection{The New Right}

The ideological framework that the fourth Labour Government, the Treasury and the State Services Commission used to legitimate the restructuring have been called the 'new right'.

James (1992:111) believes that much of what the 1984-1990 Labour Government did was "not plotted in advance. Instead it flowed from policy moves intended to be limited in scope or were intended to operate in a different policy area. But the Labour Government did tend to be radical.”

The radical changes have been seen as the revival of the central tenets of classical economic liberalism (Jesson, 1987; Apple, 2001; Marshall et al, 2000). Classical economic liberalism is characterised by representing a negative conception of state power where the individual was freed from the interventions of the state. Having been freed from state intervention it is assumed that the now autonomous individual will then exercise his or her freedom based on the belief that the individual will know what is in his/her best interests; and those best interests, based on 'the invisible hand' theory will 
also be in the best interests of society. Government's role is to adopt a 'laissezfaire' one and to let the individuals find their own level.

In contrast to classical liberalism, neo-liberalism views the role of the state as a positive one (Olssen and Morris Matthews, 1997). The state role is to create the conditions, laws and institutions for market growth and development. The role of the individual is expected to be one of an enterprising and competitive entrepreneur. Thus the role of the individual has altered from being 'free from' to one of being 'free to be' so long as it meets the demands of the market driven economy. The individual has now become 'manipulatable man' who is expected to be 'perpetually responsive' and 'flexible' to the on going changing conditions. Furthermore, to ensure the individual is not slacking, the individual is kept up to the mark by frequent evaluation using performance appraisals based on "the new middle class ideas of quality, choice and accountability" (Olssen and Morris Matthews, 1997: 22-23). This could be described as the ‘invisible hand' of governing.

A further distinction also needs to be noted. The 'new right' ideology also has a neo-conservative element. While this element shares many characteristics with neo-liberalism it has one significant difference. Specifically, neoconservatism bases its moral conservatism on "fundamentalist and individualist values which are anti-socialist, anti-feminist and antiMaori”(Peters et al, 1994:264). Unlike neo-liberalism, this view believes that poverty is:

the outcome of an inadequacy to provide for one's own needs or, in the case of a male, the family's needs, and often this is underpinned by a belief in biological determinism, which implies that there is little that can be done to assist or improve the human condition (Peters et al, 1994:264).

While it is beyond the parameters of this thesis the neo-conservative element in relation to New Zealand newspapers during the reform years is worthy of study 
in its own right because of the tensions that it raised within the 'new right' ideology, educational policies and the state.

The dominant element of ' new right' ideology, that is, neo-liberal ideology, is collectively made up of many 'right theories'. Olssen and Morris Matthews (1997:23) identify some of those theories being, “...Human Capital Theory’, 'Public Choice Theory', 'Monetarism', 'Agency Theory', 'Cost Transaction Analysis' and the revival of various forms of 'Managerialism'.” While they differ in some variants they do share many commonalities which Olssen and Morris Matthews (1997: 22-23) have summarised as follows:

\begin{abstract}
That the individual is economically self interested whom autonomously and rationally judges what is in his or her best interests and needs. At the same time the individual remains flexible to meet the demands of a deregulated market in preparation to respond to the changing market economy. The market is seen as being separate from society. Yet this uncoordinated aspect is seen to allow the individual to correlate with the interests and harmony of the whole. This is achieved by providing the same opportunities for all individuals to develop their skills and therefore optimise their identified life goals.
\end{abstract}

These 'new right' ideologies underpinned the legitimation of the restructuring of New Zealand's welfare state and it is this context that this thesis uses the more dominant neo-liberal element.

\title{
2.4 The Role of Treasury
}

In 1984 the incoming government received the Treasury's briefing paper published as "Economic Management". It differed from previous briefing papers in that Treasury criticised old policy and proposed new ones, which had more fiscal restraint. It led Douglas (cited in Butterworth and Butterworth, 1998: 35) to observe:

[The papers] had become an in depth economic briefing. Between 1982 and 1984, under Sir Robert's stewardship, Treasury had 
plenty of time to think. Strands of policy development which had been emerging over many years were being drawn together to support a total structural reform of the economy.

It also led Snook (1989:12) to comment that "Treasury confidently saw itself as the expert not only in the economy but on everythingelse as well.”

In 1987 the New Zealand Treasury produced its second volume of “Government Management” for the re-elected incoming Labour Government. The report was subtitled "Educational Issues", and reflected the new importance education was to have in implementing the new political and economic reforms based on Buchanan’s “Public Choice School” (Barrington, 1991: 296).

Bertram (cited in Olssen and Morris Matthews, 1997:14) summarises Treasury's use of three forms of capture which Treasury claimed supported their criticisms of the overburdened welfare state. These are:

- Consumer capture: which occurs when a group of users of state services secures preferential treatment against the interest of other users

- Provider capture: which refers to the situation where those who supply state services, for example, Teachers, pursue their own interests at the expense of the interest of consumers

- Administrative capture: which refers to a situation where government departments not directly involved in the production of state-provided services act to advance their own interests at the expense of the quality of those services.

\subsection{The Fourth Labour Government}

Treasury's view coincided with the major architects of the economic changes in the fourth Labour Government. David Lange, the Prime Minister considered the education portfolio so important that he held the position himself while the education reforms were initiated and implemented. Benton (Holland and Boston, 1992: 208) suggested another reason that Lange took such personal 
interest in education was because it was based on a fear of 'Maori capture' borne from the frustration of dealing with the Board of Governors at Nga Tapawai College, a secondary school in his Mangere electorate.

With the Prime Minister closely aligned to Education and Treasury closely aligned to Roger Douglas, Minister of Finance, the scene was set for rapid changes to New Zealand's economy. Douglas was an avid supporter of 'new right' theories, his style, known as 'Rogernomics', actively pursued market policies. By the time he resigned from office in 1987 the economic reforms were well under-way.

Faced with economic and unemployment crises the newly elected Labour Government adopted many of the neo-liberal tenets and undertook radical reform of the economy, including public policy, monetary policy, exchange rate policy, industrial relations, assistance to industry and trade, and foreign policy (James, 1986; Boston and Holland, 1987; Boston et al, 1991). To meet the new public management policies the public administration sector was also changed. The result was a substantial commercialisation of services on the user-pays basis. Commercial and non-commercial activities of government departments were separated. Some were changed into new State Owned Enterprises (SOE's) which were expected to operate strictly on a commercial line. Boards of directors were to be appointed from the private sector. New managerialist and decentralised forms of decision making were shifted downwards to be given autonomy and responsibility at lower levels. Public service employees had major changes to their employment terms and conditions' including contracts and wages fixing. There were stringent cost reviews and budget cuts for all government departments, and there was largescale sale of publicly owned resources to private purchasers. For some the term SOE equated with "Sold Off Everything” (Boston and Holland, 1987; Shannon, 1991). The effect was rapid and considerable with the aim to reduce Government expenditure especially in key areas such as health, education and social welfare (Boston and Holland, 1987; James, 1986; Easton, 1997). 
At the same time alternative options were put forward to the Government including, The Curriculum Review Report in 1987. This report suggested viable ways for liberalising the curriculum that would address the issues of inequality experienced by minority groups such as Maori and women. This was ignored. According to Olssen and Morris Matthews (1997:11) “A major reason being for lack of Government action on the Curriculum Review had to do with the increasing influence of the Treasury on government policy." In a bid to stem what was seen by Treasury as 'provider capture' by the teachers and teacher unions on school policy, the curriculum was abandoned. Boston (cited in Olssen and Morris Matthews, 1997:16) argued the "Fourth Labour Government shared with the Thatcher Government in Britain the TINA Principle (There Is No Alternative).”

\subsection{Summary and Conclusions}

The fourth Labour Government, with the support and consensus of New Zealand's Treasury, the influential Business Roundtable, some trade unions, the media and many middle class New Zealanders, legitimated the introduction of radical 'new right' policy changes. In sharp contrast to the social welfare model, based on the principles of egalitarianism, State intervention and protection, the Government's 'new right' economic reforms of the 1980s adopted a laissez-faire, non-interventionist, non-protectionist approach and actively encouraged, through legislation, a competitive, 'possessive' (selfegoism) individualism, which was construed as 'consumer sovereignty'. The free market claimed to have superiority on two aspects. First, the 'new right' theories advocated that this was the most efficient way of distributing a scarce resource and therefore, was a morally superior form of economy. Second, the anti-state, anti-bureaucracy stance on 'big brother' governments leading to corporatisation and privatisation to limit state intervention was believed to justify it as a morally superior form of political economy. Finally, to support such a structure, there was a corresponding shift to a moral conservatism, which was based on fundamental and individualist values. These values not only supported the individualism as described above, but also were seen to be anti-social, anti-feminist and anti-Maori. 


\section{CHAPTER THREE - THE EDUCATION REFORMS}

\subsection{Introduction}

In keeping with the neo-liberal reforms the education reforms were to be realigned so as to protect and to perpetuate the interests of the economy. Offe (1984:144) describes the role of education in relation to the state and the tensions arising between them as follows:

\footnotetext{
State agencies project an image of themselves that suggests that the use of values like education, knowledge, health, welfare and other ingredients of a 'decent life' are the final purposes of its measures and policies. The experience [is] that this is misleading, and that the State produces all these services not in order to satisfy the corresponding needs but only to the extent that it is required to keep in motion the universe of commodities with its implicit exploitative relationships of production - this experience must cause specific conflicts and attitudes of frustration over false promises.
}

As discussed in chapter one, a number of educational reports and policies were produced by and for the Labour Government (refer Figure 3:1). The Meade Report 1988, the Picot Report 1988 and the Hawke Report 1988 presented ideas that would influence the administrative reforms of early childhood, primary, secondary to the tertiary sectors of education. A common feature of all these reports were that "new management incentives were initiated in all sectors and education institutions were encouraged to adopt efficient business practices” (Lauder, cited in Peters and Marshall, 1996:68).

These reports brought an ideological shift from the principles of Peter Fraser's 1939 statement that, "Every person, whatever his level of academic ability, whether he be rich or poor, whether he lives in town or country, had a right as a citizen to a free education of the kind for which he is best fitted and to the fullest extent of his powers” (Beeby, 1992:xvi). 
Figure 3.1 Education Reforms and Policies 1988-1993*

In relation to early childhood education

Report of the Early Childhood Care and Education Working Group (Meade Report)

(Department of Education, 1988c)

Before Five: Early Childhood Care and Education in New Zealand (Department of Education, 1988b)

In relation to primary and secondary education:

Administering for Excellence (Picot Report) (Department of Education, 1988a)

Tomorrow's Schools (Department of Education, 1988e)

Today’s Schools (Lough Report) (Ministry of Education, 1990a)

The National Curriculum of New Zealand (Ministry of Education, 1991a)

The New Zealand Curriculum Framework (Ministry of Education, 1993a)

In relation to tertiary education:

Universities Review Committee (1987) (Watts Report)

Report of the Working Groups on Post-Compulsory and Education and Training.

(Hawke Report) (Department of Education, 1988d)

Reforming Tertiary Education in New Zealand (Business Round Table, 1988)

Learning for Life (Department of Education, 1989)

Report of the Ministerial Consultative Group (Todd Report) (Ministry of Education, 1994a)

Of general significance in terms of the relationship between education and the economy:

Bulk Funding of Teachers' Salaries. (Ministry of Education, 1990b; 1991c)

Designing the Framework (NZQA, 1991)

Upgrading New Zealand's Competitive Advantage (Porter Project) (Crocombe et al., 1991)

Learning to Learn (NZQA, 1992)

Education for the Twenty-First Century (Ministry of Education, 1993b; 1994b)

OECD Economic Surveys 1992-1993 (OECD, 1993)

Towards an Enterprise Culture (New Zealand Business Roundtable, 1993)

*(Adapted from Olssen and Morris Matthews, 1997: 16-17)

As Grace astutely noted (cited in Holland and Boston, 1992: 168-169), there was another principle implicit in Fraser's statement. Whereas Fraser, the 
architect of the educational welfare state held the state to account for educational provision, there was now a "reorientation of the education system" (Olssen and Morris Matthews, 1997:19) and from where the state would increasingly withdraw.

\subsection{Criticisms of the Education Reforms}

While there were cumbersome educational systems that were far from the ideal prior to 1988 not all issues were dealt with by the policy reforms and a decade later many issues remain unresolved. Academic and professional writers have covered extensively the educational problems created by the reforms. This chapter will examine a selection of issues, consistently highlighted, in academic articles as follows:

- Funding

- Choice

- Changing teachers’ roles, relationships and morale

- Curriculum, assessment and qualifications

- Decentralisation, devolution and participation

- Summary and conclusions

\subsection{Funding}

This topic was by far the most contentious of the persisting criticisms of the education reforms. The criticisms covered all levels of the education sector and will therefore be covered under five subsections.

\subsubsection{Primary, Intermediate and Secondary Schools}

The education reforms recommended that all educational institutions from early childhood education to the tertiary level be directly resourced (now called 'fully funded'). The Picot Report recommended two funds for schools, one for the day-to-day running of the school, the other for the bulk funding of teachers' salaries. While the former was implemented in 1990 the latter continued to be a matter of ongoing controversy by the teachers and boards of trustees because it was seen as a way of government cutting back on funding. According to Wylie (1999:9) 24 per cent of primary schools and 57 per cent of 
intermediate schools had taken up the offer because it gave greater 'flexibility' in allocating funds. However, Wylie (1999: 9) noted that "The Ministry of Education's own briefing papers to the incoming Government in 1996 estimated a loss of 10 per cent in school's purchasing power from 1989 to 1996.” Between 1990 and 1998, there had been a decline in spending per school in real terms in the primary and secondary sectors. While funding per student had caught up and improved on the 1990 figures, Wylie (1999: 9) thought that the increase "may have been insufficient to make up for any cutbacks and underspending on school materials which [had been] occurring in schools between 1990 and 1997.”

\subsubsection{Early Childhood Education}

Early childhood education was also 'fully funded' (as defined above) and parents made up the shortfall. According to May (1999: 23) "this [situation] had negative effects particularly as increases to the rate have been minimal. Kindergartens were increasingly portrayed by government as privileged by comparison to other services because their bulk funding was still at a higher level.” May (1999: 24) considers:

The 'Before Fives' Report was intended to enable the other services to enjoy the benefits kindergartens could provide their teachers and parents, and then to increase resourcing and support for all services. Downsizing the flagship was never envisaged... The 'Before Fives' policy was based on the assumption that early childhood services were of benefit not only for all children, but also for women, families and communities and that the state had an investment in supporting the interests of both. In 1991 the tide turned with the reappearance of old ideological battles regarding the responsibility of who supports and cares for children in society.

Although fears associated with restructuring, the use of smart cards, and voucher entitlements, did not eventuate, underfunding and the threat of targeting remained ten years later. Wylie (1993: 30) concluded that bulk funding had had an impact on the quality and organisation of kindergarten 
education with "notably more paper work for the adults involved, more use of untrained parents to fill in for sick staff and to take the place of the relievers who would have been there formerly, and more stress showing on the faces of teachers and volunteers.” Wilson et al (1996) found that the socio-economic status of the parents, along with their skill at fundraising, had led to inequalities between individual kindergartens. Although 80 per cent of the total funding had come from government, and had remained relatively constant in dollar terms over time, the proportion was reducing over time as local funds increased. Furthermore, the same study revealed that there had been a decline in voluntary help suggesting that parents were not able to be as supportive as before the reforms.

\subsubsection{Tertiary Education}

This sector had also undergone significant funding adjustments during the 1988-1999 period, which resulted in a continued shortfall as a proportion of total funding, and in terms of funding per student (Gould, 1999; Easton, 1997; Peters, 1997). Government bulk funding also applied to private training establishments at the tertiary level. These organisations were relatively new phenomena, beginning in 1996 with an initial capital injection from the National Government of a million dollars for equivalent full time places. It led Snook et al (1999:10) to observe that it was:

A clear sign of the privatising agenda of the current government... that from the year 2000 private training establishments [were] to be funded identically with state universities, polytechnics and colleges of education.

The role of education at the post compulsory education and training level (PCET) raised the question "What was the nature and purpose of such an education?” Treasury accepted Brennan's conjecture (Boston, 1990) that the externalities produced by tertiary education were small, and therefore were not a merit good or a positive right. Thus tertiary education benefited the individual only. Yet Treasury also held the view that in order to maintain equality of opportunity as a social function state funding was justified. Boston 
(1990:168) described this as 'the entrepot' function of universities (that is, their role as repositories of knowledge and culture).

There were major difficulties in reconciling such diverse viewpoints but they were resolved by introducing a policy regime characterised "by higher (but subsidised) fees, means-tested student allowances, and a government-funded, income-contingent loans scheme based on the principles of user-pays and targeted social assistance” (Peters, 1997: 233).

Early writings by Boston and Dalziel (1992), Holland and Boston (1992), and Peters et al (1992) predicted the outcomes that these changes would make. In particular they believed the new regime would discriminate against mature students, Maori and women; and would have a negative effect on low and middle income class families. The scheme was seen as creating family dependency for single students, penalising postgraduates and having negative implications for university research. The scheme was also criticised for increasing administrative costs and generating incentives for abuse. Finally, the scheme was seen to compromise New Zealand's long-standing open entry policy. Boston and Dalziel (1992:ix) noted, "that under the banner of 'Creating a Decent Society' the National Government [had] abandoned any commitment to an egalitarian society, let alone the further extension of citizenship rights.” Easton (1997) went so far as to suggest that all PCET should be free because virtually all students continued to the tertiary level. Therefore, it would be in keeping with the 'free' concept of primary and secondary levels of 'free' education.

According to Parr (cited in Olssen and Morris Matthews, 1997), seventh formers saw user charges as a deterrent to continued participation in tertiary education and that the cost of tertiary education had impacted unevenly on students, thus compromising the principles of open access. The ability to pay was also likely to be unequal and was seen to penalise Maori, Pacific Islanders and mature women students. Peters (1997: 235) cites The Student Casebook (NZUSA, 1996) that asserts: 
Based on qualitative evidence, the [finding] suggests that debt has negative impacts on family and relationships, savings, future disposable income and debt servicing, study choice and performance.

Analysis on user charges on students, during the 1988-1999 period, found that there was a downturn in the number of students enrolling in tertiary education institutions. Seventy per cent of students under the age of 25 years were ineligible for state provided funding because their parents' income was above the threshold set for eligibility. The Official New Zealand Year Book (2000: 229) showed that in 1998 more tertiary students graduated from New Zealand's 23 polytechnics 29,7370 compared with 26,181 from universities suggesting vocational courses were seen as being less of a risk and more cost effective in terms of finding employment.

Another, more recent, analysis by Hughes and Pearce (2003) has suggested that the student loan scheme may not have been the only reason for low participation rates of students from low decile schools. Hughes and Pearce suggest that, rather than the student loan acting as a deterrent, it was the lack of qualifications that prevented such students gaining entry to tertiary level education.

However, concern about mounting debts from student loans remained to the fore. Of particular concern was the exodus of graduates who left for greener pastures overseas. In August 1999, for example, the total student debt reached \$3 billon dollars (Snook et al, 1999:11-12) and the average debt level of students or former students who had remained in New Zealand was \$11,625; for those who had left New Zealand the average was \$14,089. Over \$101 million was owed by at least 3,840 people living overseas and according to Gordon (cited in Snook et al, 1999: 12) "this number [was] increasing by 1000 per year.”

Gould (1999) points out that buying higher education can also alter the expectation of the purchaser (student). Having 'bought' a higher qualification 
the student could expect to have the qualification as fair exchange and thus see any failure as the provider's fault. Yet the role of any educational institution is to maintain acceptable standards of achievement.

Universities in particular, who value their academic independence, take a longer term, wider community-based view of the national interest in acting as “critic and conscience of society” (Gould, 1999: 29). As Gould (1999: 29) points out no student is going to say, "Here is $\$ 10,000$ for this year's courses and here is a couple of hundred so that you can act as critic and conscience of society.”

While the market allows for failure on the premise that it encourages innovation and efficiency the market ideology is not the best place for delivering a commodity which society has an interest in ensuring always maintains its value. In short, "Buying a tin of baked beans is not the same as offering a student a once in a life time chance of accessing education” (Gould, 1999: 29).

\subsubsection{Vouchers}

One of the less high profile government funding schemes of schools during the 1988-1999 period was the quasi-voucher system. New Zealand has openly rejected the idea of having educational vouchers. Wylie (1998: 6) describes the term voucher as referring to:

\footnotetext{
Various different forms of funding education. These range from individual scholarships for private school attendance, and/or systems of open enrolment, self-management and per capita funding formulae in public schools only, to systems which use public money to fund public and private schools alike.
}

Those who advocated neo-liberalism saw the use of vouchers as a way to improve education through competition between schools, fostering of diversity, innovation and efficient use of resources, and improvement in the quality of education. Parents would have a choice resulting from sound 
educational decisions and low income students would have better access to where there was a free choice of school (Wylie, 1998; 1999a).

In New Zealand the National Government operated a quasi-voucher system based on what Wylie (1999a) described as having three core mechanisms. First, there was student funding where money was targeted for disadvantage. Thereby one school could receive more than another serving an equivalent group of students. Second, the school was responsible for the management and allocation of the government funding and third, school enrolment was based on 'choice' rather than on location or as a right of entry to the neighbourhood school.

Over the 1988-1999 period the National Government introduced a method of funding to both public and private schools with an increasing emphasis on student funding based on individual characteristics as well as school characteristics. As a result staff based funding decreased as were funds based on 'inclusion' (Wylie, 1999a). Furthermore, there was a blurring of the lines between public and private schooling. During this period those lines may have been crossed, as judged by Wylie (1999a), because of the ease in which private schools could integrate and receive an increase in government funding in return. In addition to the extra increased government funding of private schools, there were 'targeted individual enrolment schemes' where children, from low-income families could attend private schools providing a national curriculum. The scheme was funded from new appropriations rather than from existing government funding. Wylie (1998; 1999a) saw this as creating an imbalance between private and state services. The imbalance, according to Wylie (1999a; 1998), served to increase inequities rather than resolve them, because the lower decile schools were left unsupported and, despite concerted efforts discussed earlier, were often left in 'a spiral of decline'.

\subsubsection{Voluntary Fees}

During the 1988-1999 period academic and professional writers noted that schools were increasingly selecting their students based on the students or parents ability to pay. Such user-pays method of selection led to where state 
schools were starting to behave like private schools. School fees were seen as 'voluntary' yet the Consumer Magazine (Wylie, 1999a:104) found from 41 state and integrated schools surveyed that 33 had increased their fees. The primary schools in the sample varied from $\$ 66$ to $\$ 110$ while secondary schools varied from \$255 to \$450. Although anecdotal, Wylie (1999a) found integrated schools to be much the same.

While these fees were 'voluntary' there was an expectation parents would pay and Wylie (1999a: 104) noted that, "Some schools do put illegal pressure on parents and students to pay." In addition to the pressure to pay school fees Wylie found that in the primary sector parents' spending on their children's education (including transport and school trips) increased from of \$187 in 1991 to \$491 in 1996; an increase of 263 per cent in five years (1997a: 33). The increase in the consumer price index over the same period was 11.5 per cent. "Parents in professional occupations were spending an average of \$647 per year, compared with $\$ 431$ for those in skilled and semi-skilled work, $\$ 450$ for those in unskilled work and \$377 for those parents receiving state benefits” (Wylie, 1997a: 33).

Gilling (cited in Wylie, 1999a: 104) also noted that, "some schools were making a profit from the activity fees.” Gilling speculated that it might also reflect schools making an effort to offset the real decline in terms of government funding. For some parents, the high cost of activity fees were seen by Gilling (cited in Wylie, 1999a) as having an effect on 'choice', because only the wealthier parents could afford the high fees.

Although anecdotal, Wylie (1997a; 1999a) identified a possible growth in school decision making based on self-interest. Schools appeared to be exercising student selectivity based on enrolment schemes, school-funded bursaries and, during the late 1990s, overseas paying students. The hard to service or expensive student, that is those with special needs or one that might affect public perception of the school's reputation, were selected out. In some areas of education, such as special education and fees from overseas students, the funds were not being monitored. Therefore, the funds could be used for 
other purposes than what was intended. According to (Wylie, 1997a; 1999a) the funding could be directed into other areas that the school believed essential for its proper functioning.

The outcome of the government acting as purchaser rather than provider was that there was pressure to reallocate limited resources among a greater number of providers so questions concerning the adequacy of funding, the inefficiencies, and whether student needs were being met, were side-stepped. With decentralisation there had been a need for accountability which had led to the government producing “formulae funding” (Wylie, 1999a: 106). This had the 'unintentional' impact of putting schools in competition with one another for funding. Conceptually this was different from "contestable funding" (Easton, 1999: 252) where the funds were available based on proven need. According to Wylie (1999a) the rationale behind the changes in the methods of funding made it possible to describe New Zealand as having a quasi-voucher system.

The question raised was “Does it matter?”. Wylie (1997a; 1999a) argued that the findings of her research showed that the voucher system failed in improving the lot of children from low-income homes and minority backgrounds, thus increasing social segregation. The voucher system had failed to stimulate diversity, instead it had increased conservatism especially when national benchmarks were used to judge schools performance in terms of success or failure. Increased competition only benefited a small minority and could lead to lower levels of student achievement in schools from low-income homes, thus depressing overall achievement levels. Furthermore, New Zealand had no safeguards to counter the increasing inequalities. State funding, either directly or indirectly had, despite denials to the contrary, led to inequalities in terms of access, outcome and the rewards society offers. State funding had been reduced while "privatisation by stealth” Wylie (1999a: 99) had replaced the balance. 


\subsection{Choice}

According to neo-liberal ideology the quality of educational choice lies in relation to having a 'voice' and being able to 'exit' to a more suitable alternative if that voice is not heard (Boston, 1999). Underpinning these notions is the belief that decisions made by the consumer is superior to that offered by providers with expert knowledge (Peters and Marshall, 1996). The rational decision made by the consumer is considered to be better for the individual, for the school and the community.

\subsubsection{Zoning and Enrolment Schemes}

To exercise parental choice school zoning was abolished in 1991. This enabled consumers to exercise their choice. It also removed the protection of schools with declining rolls from open market forces. To protect popular schools from oversubscription 'enrolment schemes' were introduced. Enrolment schemes were more likely in areas of high growth, and in high decile areas "ranging from 30 per cent of decile 8-10 schools to 9 per cent of decile 1-3 schools" (Wylie, 1998:80). Ladd and Fiske (cited in Wylie, 1998:80) found, "in Christchurch that 100 per cent of decile 7-10 secondary schools had enrolment schemes despite the declining rolls in that area.” Wylie (1998:81) believed that Ladd and Fiske's research revealed the declining rolls had led to a masking of the problem of inclusion and exclusion of students, rather than protecting schools from "oversubscribing”. Wylie (cited in Snook et al, 1999:16) believed, “a good deal of 'gerrymandering' [occurred], particularly by the elite schools of Auckland.”

The Smithfield Project, a longitudinal study of market values on education, traced the impact of school choice policies on schools, students and their families in two cities during the decade of the 1990s. The study found that the schools with the lowest socio-economic (SES) mix faced the greatest decline in rolls in year 9; for lower SES parents there was a significant gap between the school they would have preferred to have sent their children to and the one the children actually attended. In particular, Maori and Pacific Island children in lower SES groups were less likely to be admitted to higher decile schools even when their scholastic attainment levels were comparable. For lower SES 
parents class inequities prevented their children attending the school of their choice. Eighty per cent of Maori and Pacific Island children were found to be in decile 1-3 schools compared to 1.8 per cent of Pakeha. Education markets therefore, were seen to polarise intakes and create 'spirals of decline' which were found to have more to do with the nature of intakes than with the quality of teaching. Students from lower SES backgrounds were more likely to go to their local school than to a preferred school of their choice outside their area (Lauder et al, 1994; Lauder et al, 1995; Lauder et al, 1999).

Gorard and Fitz (1998) have questioned the Smithfield Project's findings and suggest there is initially a 'starting gun' effect where alert parents take advantage of the removal of the restrictions on zoning. Gorard and Fitz argue that over time the less advantaged will also take the opportunity to attend better schools and ultimately choice, through market forces, will lead to less segregation. But Awatere-Huata (cited in Stirling, 2002: 22) reported, "that 30 per cent of Maori children who travelled out of zone to schools did so because the students could not get into their local school.” Awatere-Huata saw parent and student choice as being illusionary. For Awatere-Huata (cited in Stirling, 2002:22), the effect of balloting based on entry enrolment schemes had:

Locked Maori into ghettoisation. Few will be able to move out, because they will not be able to afford to move into upper-decile school zones. Balloting has removed the incentive to strive and teaches children that "life is a lottery".

A decade after the education reforms were initiated and implemented studies continued to that show polarisation and segregation were still very evident in New Zealand.

Thrupp (1999) has suggested that many high decile schools' achievements have much to do with the social mix, that is, the social class composition of a school's intake than is generally realised. Thrupp suggests that it is the school mix that powerfully influences the likely effect on student relations, classroom instruction, school organisation and management. Thrupp (1999:5) believes 
"the likely effect will lift the levels of student achievement in the middle class settings and reduce the levels in the low SES settings.”

Snook (2000:10) suggests that "ninety per cent of achievement is due to the social background of students.” Dale (2000), using the Elley-Irving SES scale, found a direct relationship between social class and levels of achievement. Those students who came from the top three SES levels that is, professional, management and office, sales and technical, actually achieved more than would be expected with their measured ability; while the lower SES levels, that is, the skilled trades, semi-skilled and unskilled jobs, the findings were reversed. Those three levels were found to do worse than predicted. Dale (2000: 116) explains these findings in terms of Bourdieu's "Cultural Capital” which has three components - dispositions of body and mind, cultural goods and educational credentials.

Within families, cultural capital is still reproduced in the home in the form of dispositions, values and expectations. Bourdieu sees these cultures as being capital (Codd et al, 1990). The dominant class of contemporary capitalism can ensure the reproduction of their existence through distinctive knowledge and social networks. A characteristic of cultural capital is its convertibility. With little financial risk to the dominant classes, financial capital can be converted to social and cultural capital through schooling, and social and cultural capital can be reconverted, through mediation with the school, to financial capital gained through employment. In the reconversion process the school's role is all-important. As Codd et al (1990:12) explains:

Cultural capital acquired in the home is recognised accurately by the school as an indication of receptivity and confers a virtual right to its academically structured knowledge. Once duly certificated as the possessor of this knowledge, an individual is identifiable by class habitus and scholastic habitus as one with both the capacity and right to assume a career in the decision-making divisions of capital and state organisation. This symbolic power has become actual power. 
Schools, acting in self-interest and preservation, can market their high achievement rates such as favourable Education Review Office (ERO) reports and examination results. Measuring a school by these results does come with warnings from the Ministry of Education against making simplistic judgements based purely on results. But parents often have little other reliable information available to them. McKenzie (1997:53) cites Lee and Lee's research, which has amply demonstrated that:

In New Zealand the external examination system has long appealed to the upwardly mobile in a market excluding way; i.e. the examinations which are most highly regarded are those whose scarcity value arises from them having a selective entrance population.

McKenzie (1997) concludes that the unpalatable outcome from their argument is that the more worthwhile that an examination is for the upwardly mobile the more people there must be in the general school population who either sit the examination and fail or who never enter the examination at all. Publishing success rates of those passing external examinations belies the fact that in order for a school to secure its reputation as being efficient, and therefore educationally desirable, it only needs a handful of their students to pass.

\subsubsection{Marketing an Image to remain Competitive}

Marketing a school also relies on 'image'. In an article titled “Twilight Zones” Stirling (2002:19-23) described how one principal, from a decile three school that was in a spiral of decline, successfully repackaged and marketed the school's image by making it look like a decile ten school. The principal's aim was to have 70 per cent middle class enrolments because he saw "education as a middle class thing.” To achieve his goals the principal had introduced an expensive blazer for the students to wear. With the help from the local business and community sectors he had had the school's buildings redecorated inside and out. The school also advertised their external examination results (which were better than a local decile 10 private girls' school). Furthermore, the principal had personally guaranteed student safety; and during this time he had 
suspended many students for unacceptable behaviour. As a result parents, staff and students were attracted to the school and they had stayed. There had been an exiting of the Maori and Polynesian students whom the principal regretted and he 'hoped to redress'. Within a few years the school had been turned around. Now there was a waiting list and the school could select their staff and students to ensure that the school remained small so as not to lose its intimacy. As a result, the improving school circumstances had led to increased selectivity and the legitimation and motivational crises were moved elsewhere to become a problem to the parents, another school and/ or the community.

Wylie, (1999) found that from 1996 many principals had felt their schools were competing with others and that parents and students were exercising their preference, particularly for schools with low or very low Maori enrolment. Therefore, the reforms had acted in an "unintended manner which had increased ethnic polarisation in primary schools as well as secondary [schools]" (Wylie, 1999:160). Because of reducing roll sizes and instability of rolls, resource allocation that was keyed into enrolments contributed to the schools' lack of development and exacerbated the instability and roll decline (Wylie, 1999). Schools who were losing students and competing with other schools "appeared to be as open to change and willingness to be responsive to others, if not more so" (Wylie, 1999:160). Despite school promotion and marketing, and meeting family needs by providing after school programmes, schools still failed, particularly the low decile schools. Ironically, Wylie (1999) found the high decile schools were less likely to have to compete.

Schools however, once having attracted their selected student, needed to maintain student, parent and community participation. Dale and Ozga (1993:79) found that, "Parents' collective interests in the welfare of the whole school [were] subordinated to their individual interests in the welfare of their own children in competition with other children.” Thus, there was a very low turnout of parents attending meetings concerning school-wide issues. Harold et al (1999) found that few boards of trustees became involved with the curriculum and assessment areas and Wylie (1999) found parental and community consultation involvement had declined over the ten years. While 
external influences such as women returning to the paid workplace was a factor, those who were unemployed, on benefits and Maori were also less likely to be involved with their children's schooling.

Consequently, there was a polarisation between those with a 'treacherous voice' (Hirschman's concept in Dale and Ozga, 1993) where the consumer created the situation that suited them, but which would not always be to the benefit of the school nor to those who had 'no voice' and 'no choice' in the type of education suitable for their children.

\subsubsection{Illusionary Choice}

Therefore, choice for many consumers was largely illusionary. Consumer demand could not be seen as the equivalent to social demand. The distribution of resources had become inherently inegalitarian with the richer schools tending to become richer, more selective, and ironically, less competitive. The 'treacherous voice' compromised democracy through loss of co-operation within the school and the community. Loss of shared interests led to loss of altruism, empathy and respect for persons. Thus the concepts of 'freedom from' (in the Rawls' sense) and 'equality' created tensions in which the latter was at the expense of the former (Peters and Marshall, 1996: 73).

\subsection{Changing Teacher Roles, Relationships and Morale}

During the reform years the traditional role of teachers came under serious and persistent pressure to be more in tune and to reflect neo-liberal ideology. According to Snook et al (1999:18) "Prior to the reforms comparatively 'congenial' relationships existed between successive governments, the Department of Education and teachers' associations.” Treasury, however, thought those relationships created 'provider capture' and therefore was keen to 'reform' such arrangements.

By 1997 and onwards teaching in New Zealand was seen to be in crisis. Sullivan (1999:144) described the previous ten years as "not being teacher friendly." During those years there was massive teacher shortages with teachers being recruited from overseas to fill the vacancies. Shorter training 
courses were 'rushed' through colleges of education and universities to replace the teacher losses. The problem was compounded by unprecedented enrolments in schools and schools decreasing enrolments in teacher training programs. In respect of the latter, student leavers appeared to have opted for more intrinsically and extrinsically rewarding occupations. All of this was accompanied by a mass exodus of teachers from the profession.

Teacher dissatisfaction was voiced in marches on parliament, strikes and stopwork meetings. Many of these dissatisfactions were related to salary and pay conditions. Sullivan (1999:145) saw these as being 'symbolic' in the context of the treatment teachers received from the government, the media and the public.

\subsubsection{Conflict between Teachers' and The New Right Ideologies}

While Sullivan $(1997 ; 1999)$ acknowledges the real concern that the above claims have, he also sees them representing an ideological clash between the proponents of the 'new right' reforms and those proponents of educational ideology. At the heart of the conflict have been different assumptions about human nature, society, the role of the state, and the role of education, teachers and teaching.

Education ideology in New Zealand remains based on Dewey's philosophy (Marshall, 1997; Marshall et al 2000; Sullivan, 1997) with the assumption that humans are social and co-operative, and they enter into a social contract with others. Education is child centred and in New Zealand education is considered to be a universal right. The role of the state is to provide for basic needs. Therefore, the role of teachers and teaching is to meet those needs, including the importance of addressing issues of inequality of social class, ethnicity and gender. Differences are to be valued and catered for accordingly. Teaching should be creative and enjoyable and the teacher, as a professional, should have the freedom to exercise his or her autonomy. The environment is one of caring, sharing and co-operation. Education programs and practices should reflect those assumptions and educational goals. 
The underlying assumptions of the 'new right' have been discussed in chapter two. These underlying assumptions, goals, policies, programmes and practices have altered the role of education, teachers and teaching in two ways. First, education has now become a consumer driven commodity and second, education has to be competitive to ensure quality, efficiency and standards of excellence. The implication being that existing public education is inefficient, ineffective and wasteful (Sullivan 1999). To meet these new principles, the teachers' role changes from being a professional to that of a provider, or as Gordon (1993:33) describes, “from professional to proletarian.” Teacher autonomy is lost and replaced by a prescribed curriculum and performance appraisals. Educational goals refocus on 'new right' reforms to encompass a market-orientated curriculum and teachers refocus to meet those goals. Thus educational policies, programmes and goals shifted to include teacher appraisal systems, performance related pay, no mandatory registration (which was later reversed), contracts and curriculum reform. Educators hotly contested these policies, programmes and practices and in some cases there were some changes. However much ambivalence to the 'new right' policies remained (Harold et al, 1999).

Furthermore, the change in legislation in the State Sector Act 1987, the Public Finance Act 1989, the Education Act 1989 and the Employment Contracts Act 1991 laid the foundation for a top-down hierarchical system in education. As a consequence, Sullivan (1999:144-145) noted that:

In place of the partnership which was developing between teachers and parents prior to the reforms, what has developed is an outmoded and hierachical business structure. Parents as employers (boards of trustees) are at the top of the ladder, principals as managers are in the middle, and the teachers - the professional are employees at the bottom.

Further constraints on teacher autonomy also came from ERO and the Teachers' Registration Board (TRB) which Sullivan (1999:145) described as being "institutional manifestations of this ideology." On the one hand ERO 
review processes encouraged a regime of performance management in schools, while on the other, the TRB had made inroads into teachers' professional autonomy and carried out duties that in Sullivan's view “should definitely rest with a professional association” (1999:145).

The New Zealand Qualifications Authority (NZQA) was another institution that impacted on teachers' roles. As NZQA and ERO continued to grow and develop their influence on curriculum and assessment increased and tightened the control upon teachers' roles and conditions of service through the process of performance management. The uncoupling of teachers' professional role to market ideology further contributed to tensions arising from the new reforms.

\subsection{Curriculum, Assessment and Qualifications}

Changes in curriculum, assessment and qualifications began in the early 1990s with the National Government introducing 'seamless' education, a philosophy that was intended to encompass primary, secondary and some tertiary levels of education. This was an attempt to produce, at a lower cost, skilled workers who would be flexible and prepared to meet the ever-changing market forces. Such a scheme was to give New Zealand a competitive edge in an everincreasing globalised economy. The assessment and qualifications administered by the newly established NZQA were to reflect those changes espoused on notions of quality, excellence and accountability. As a result, assessment and qualifications became tightly specified and, as previously discussed, providers and teachers too became more closely monitored and accountable.

\subsubsection{Curriculum and Assessment}

Curriculum and assessment policies during this time focused on specifying, through achievement objectives, what students were expected to know and do. Furthermore, students' learning was to be monitored. Following a $1991 \mathrm{draft}$ document on the national curriculum, a national curriculum framework was published in 1993. This document described the main features of the curriculum including the seven essential learning areas and the eight groupings of essential skills which schools were required to implement. There were also 
parallel curriculum statements for Maori. Accompanying these lists was the requirement for schools to follow the National Educational Guidelines (NEGS) and National Assessment Guidelines (NAGS). One of the main functions of ERO was to monitor schools on a 3-year cycle to ensure compliance and that standards were maintained.

Responses to the curriculum changes were, in the main, accepted at the primary, intermediate and lower level secondary schools (Philips, 2000; Wylie, 1999). However, Wylie (1999) found that while teachers had become more confident in curriculum delivery they were less confident in assessing the curriculum. Teachers would have liked more support and resources in conducting assessments. In addition, while teachers had seen some benefit to assessing work in responding to meeting children's needs, it had come at the cost of increased loss of time in other areas, for example, providing individual attention to children, or preparing or planning lessons. Wylie (1999: xviii) found that teachers were "assessing children more rather than rationalising the number of assessments they use. Spelling tests were much more common now for children in the first 3 years of school than in 1989.” Assessments were also used by teachers to provide information on their class programmes, to give assessment data to their boards, and to give to ERO as proof of student achievement (Wylie, 1999). Apple (cited in Fitzsimons et al, 1999:42) described this as "teacher proofing the curriculum."

\subsubsection{Unit Standards}

The fundamental building blocks to the assessment for the National Qualifications Framework were the 'unit standards', which were designed and assigned according to their levels. The underlying intention of the 'seamless' education was to enable each student to move, with ease, through programmes and learning establishments.

Hall (1994:4) defined the unit standards as being “A set of 'elements' (outcome objectives) which students/trainees are expected to achieve in relation to specified performance criteria." Unit standards were to be 
developed by National Standard Bodies or Tertiary Training Organisations and were required to be registered. Hall (1994: 5) describes that under this model:

The elements and performance criteria given in the unit standard act like coat pegs on which providers are required to hang their content, teaching and assessment procedures.

\subsubsection{The New Vocationalism and Criticisms of Unit Standards}

Fundamental to the curriculum changes was the question "What counts for knowledge?" The curriculum at the primary, intermediate and lower secondary levels has been criticised by Elley (cited in Philips, 2000) for its structural soundness. An unlikely ally for Elley came from the New Zealand Business Roundtable. Irwin (1999:157) saw that, “all learning areas [were] assumed to have equal priority at least for the first ten years.” Michael Irwin criticised the 'one design fits all students' regardless of the child's ability or future occupational journey.

However, much of the criticism about unit standards came from within higher education in New Zealand and, in particular, the merging together of the vocational and academic distinctions as promoted by the Hawke Report (1988). As a result education came to be seen as a commodity called 'Vocationalism' based on busno-technocratic/instrumentalist beliefs (Marshall, 1997; Marshall et al, 2000; Roberts, 1997)). Codd (1997:135) argues:

There is essentially a denial that knowledge can be seen as an end in itself; indeed it is tantamount to a denial of the time-honoured role of higher education in an open society where knowledge can be pursued for its own sake and where the university can truly be the 'critic and conscience of society'.

Knowledge therefore, became redefined in technocratic terms against which performance was measured. In respect of measuring learning outcomes through unit standards, a common criticism was that the approach was too inflexible and too simplistic for complex learning. Specifically such 
measurements used in a complex learning situation were criticised for creating fragmentation and atomisation of learning. Furthermore, such performance measures failed to take into account the learning context. Not all learning outcomes could be based on checklists and examinations (Roberts, 1997; McKenzie, 1997; Elley, 1996; Harold et al, 1999).

In addition, unit standards were criticised for focusing on competence rather than excellence, which in itself was contradictory to market ideology. The New Zealand Business Roundtable (NZBR) also expressed concern about unit standards (see Irwin earlier in this section).

The Employers' Federation also appeared to have held contradictory views. On the one hand they wanted an education system built on the language of skills, based on market ideology of competition in the workplace, but at the same time wanted traditional mechanisms such as examinations to remain (Roberts, 1997).

At a different level, criticism of unit standards has been based on conflicting ideologies. Codd et al (1995: 33) describe the conflict between political imperatives as a kind of 'Janus Policy' where "the policy of student assessment [was] being driven by two conflicting agendas with educational professionals on the one side, and New Right advocating accountability, manageralism and market forces on the other."

\subsubsection{The Role of the Education Review Office}

Prior to 1988 teaching performances had been monitored by the Department of Education and had been seen as being “too tame” (Snook et al, 1999: 320) because the department had been made up of former teachers and principals.

In 1988 Lange accepted the recommendation from the Tomorrow's Schools review and established an independent review office - the Review and Audit Agency (later renamed the Education Review Office). Its role was to ensure that the educational institutions were accountable for the government funds and for meeting the objectives set out in the schools' charters. The Picot 
Taskforce (cited in Snook et al, 1999: 33) specifically saw the role of the Audit and Review Office as being:

A co-operative attempt to improve the quality of the education being provided, in the same way that an institution will from time to time engage consultants to provide a wider impartial and informal assessment of its progress towards its objectives.

Early assessment suggested that there was a positive attitude toward the agency among the schools with the agency assisting rather than inspecting schools (Snook et al, 1999). However, in 1990 the partnership model of review changed rapidly following the recommendations made by the Education Reform Implementation Process Review (known as The Lough Report). This review recommended significant reductions in staffing and budget levels for the Review and Audit Office, and the introduction of a standardised methodology that aimed "to directly rectify deficiencies in the operational administrative practices within schools...[by] concentrating on outputs and outcomes” (Snook et al, 1999: 33).

Lockwood Smith, the Minister of Education in the National Government, accepted the recommendations and ERO became focused on two output classes. The first would "examine the extent of compliance with contract requirements including the quality of service delivery" (Smith, cited in Snook et al, 1999: 33). The second focus concerned effectiveness reviews that would "evaluate the contribution made to student achievement in terms of both standards and progress, by the management systems and practices of the institutions” (Snook et al, 1999: 33).

According to Snook et al (1999), between 1992 and 1997 when ERO's review format and funding changed, considerably less attention was paid to educational effectiveness while more attention was given to ERO's policing and audit functions. Thus the focus shifted from educational effectiveness to realign with the market ideology of the 'new right'. 
Interestingly, Wylie's (1997a) study found that few principals, teachers or board members wished to return to the old system, although there were two exceptions to this. The first was for a return to the old style inspectorate, which offered an informal support structure for principals and teachers. The other was for more inclusion of teachers in the development of curriculum policy, which had been a strong feature prior to the reforms.

While teachers and principals appear to have generally accepted the changes since the Lough Report's recommendations, academic and professional writers have been more critical of ERO's role. Thrupp and Smith (1999) have criticised ERO's methodology for failing to rely on self assessments and little guidance on review activities such as interviewing or observation, lack of transparency about review procedures and poor information. In particular, Thrupp and Smith (1999) have criticised Aitken, the Chief Executive Officer from 1992 to 2001, for failing to take into account any external problems outside the school's control that can have an influence on the management of the school. These external influences Aitken believed "need not, and must not be allowed to have an impact on schools” (Thrupp and Smith, 1999:194). Thrupp and Smith saw low SES schools as being scapegoated as a result of such reviews.

Robertson et al (cited in Thrupp and Smith, 1999:194) argued that ERO reports "may inadvertently encourage schools to direct their energy towards meeting compliance regulations rather than genuine school improvement.” Wylie (1999) found that generally teachers over the years had learned to comply with ERO's assessment expectations, supporting Thrupp and Smith's (1999:194) claim of 'ERO proofing', as schools worked to avoid a negative review. The longer-term price was seen to be at the expense of student learning as "silly demands [were] met and staff energies [were] lost to the need of genuine school improvement” (1999:194). Wylie (1999) and, Thrupp and Smith (1999) point to 'value-added' practices of dubious value and more time spent in producing and maintaining records and less time engaged in more creative, diverse and reflective teaching. 


\subsubsection{Technocratic-Reductionist Market Model of Evaluating Education}

Codd (1994) sees the contradictory discourses of education evaluation being between the 'technocratic-reductionist market' model on the one hand, and the 'professional-contextualist' model on the other.

The 'technocratic-reductionist' model is focused on the skilled technician who is evaluated on competence in achievement of specific learning outcomes. Administratively this is hierarchical in nature where extrinsic motivation provides the impetus and can be evaluated in terms of contractual compliance.

On the other hand, the teacher is a reflective practitioner who, "seeks to integrate theory with practice through a process of critical self-evaluation and practical deliberation” (Codd, 1994: 51), using a 'professional-contextualist' model.

According to Codd (1994) another important distinction between the technocratic-reductionist and professional-contextualist models is the criteria of good practice. While the technocratic-reductionist model can be reduced to a set of well defined skills that require no moral dimensions, the professional model views a good practitioner to be, "a well-rounded person who can integrate all aspects of their prior knowledge and act in a teaching situation with moral integrity” (Codd, 1994: 51).

However, Codd (1994) considers the sharpest contrast between the two models exists in the organisational approach. The professional-contextualist model has a "more open-ended approach to curriculum design, enabling the emergence of unanticipated outcomes and development of diverse human capabilities such as creativity, imagination and critical thinking” (Codd, 1994: 51). To achieve this a collaborative educational leadership approach is necessary. Such a context could not be achieved in a technocratic-reductionist model because it requires efficiency and hierarchical management practices (Codd, 1994).

Finally, Codd argues that the models have very different assumptions about human nature. The technocratic-reductionist model sees that, "teachers are 
motivated by extrinsic rewards. Hence the current proposals for payment by results” (1999: 51). On the other hand, the professional-contextualist model believes that teachers are, "intrinsically motivated", work "co-operatively" with colleagues, form professional commitments which are seen as contributing to a “moral responsibility” (Codd, 1994: 51).

With the tension and conflict between these two ideologies, Codd (1999: 45) believes a "culture of distrust has emerged in relation to professional accountability.” Professional accountability implies having a high trust of the professional (teacher), an acceptance of professional responsibility, commitment, loyalty and a sense of duty. The professional is accountable to many, which often involves a resolution of ethical dilemmas through a process of reflection or deliberation. Codd (1999: 52) concludes:

In this form of accountability, the educational practitioner cannot avoid the exercise of professional discretion, where this may even require refusal to conform with managerial expectations or directions.

Codd (1999) believes it is only the professional practitioner who can have the responsibility for maintaining the standards of practice of the occupation. Thus tension, conflict and lack of trust exist within the teaching profession, who use the 'professional-contextual' model while at the same trying to implement curriculum, assessments and qualifications based on a 'technocraticreductionist' model. The result is that the collegial partnerships between the teachers and the central agencies that existed prior to the reforms have now been lost (Codd, 1999; Thrupp and Smith, 1999; Wylie, 1999).

\subsubsection{The Paradox of Curriculum, Assessment and Qualification Reforms}

The intention of the curriculum, assessment and qualification reforms were to redress the existing inequalities. However, unintentionally, the reforms have been seen by some academic writers to have created a paradox. The curriculum has redefined what is worth learning to a narrow simplistic concept of learning, which is then narrowly monitored to maintain questionable standards at the 
expense of education and where the learner comes second place to market ideology (McKenzie, 1997; Fitzsimons et al, 1999; Codd, 1993; Codd, 1999; Wylie, 1999; Thrupp and Smith, 1999; Roberts, 1997).

\subsection{Decentralisation, Devolution and Participation}

After the 1988 reforms, the previously controlling authorities from early childhood to tertiary institutions were abolished and the responsibility was transferred to the individual schools, early childhood centres and the tertiary institutions that then became responsible for their administration. The Department of Education, widely thought to hold too much power, was subdivided into three; a Ministry of Education, the NZQA and ERO. Also established were Specialist Education Services, Career Services, the Teacher Registration Board, and Skill New Zealand (Snook et al, 1999).

\subsubsection{The Transfer of Power and Responsibility to Local Administration}

The Tomorrow's Schools reforms embodied a significant move toward transferring power from the central agency (the State) to local authorities (parent, school and community). What was less clear was whether the move to local authority was one of decentralisation or devolution. Decentralisation is where the greater responsibility is passed to the local region from the central authority, while devolution is the transferring of power to the local region (Barrington, 1998).

The move to a decentralised, school-based management, was seen to be a radical move at the time. The rights and responsibilities gave each newly established board of trustees "complete discretion to control the management of the school as it sees fit" (Barrington, 1998: 82). The ultimate legal responsibility lay with the board of trustees while the day-to-day running of the school was left to the principal (Barrington, 1998). The 'school charter' was to be the lynch pin of the reform providing a key mechanism for devolution and accountability. "Charters were to be a contract between the state and the institution, and between the institution and the community" (Snook et al, 1999: 31) through which equity objectives would be ensured. Barrington (1991: 302) 
cites the following paraphrase from the "Tomorrows Schools Report" on its view of equity at the local level:

a new system of education administration promotes and progressively achieves greater equity for women, Maori, Pacific Islanders and other groups with minority status; and for working class, rural and disabled students, teachers and communities; equity issues are integrated into all aspects of changes in education administration and not treated as an optional extra (New Zealand Government 1988, para. 3.1.1).

\title{
3.7.2 The Role of the Central Agency
}

By 1991 the central-local issue was still seen by the Treasury and the Minister of Education, Lockwood Smith, to be too centralised and bureaucratised. According to Lockwood Smith:

\begin{abstract}
Achievement of equality implies centralised decision making, centralised control of resources and a welter of regulations, where as freedom and choice in education implies local decision making, local control of resources and a minimum of what parents and schools can and cannot do (cited in Barrington, 1998: 83-84).
\end{abstract}

The outcome from the National Government's decision was, paradoxically, to disestablish the Parents Advocacy Board, which would have given the parents a direct 'voice' to the Ministry of Education. The Community Education Forums were also abolished, thus reducing the communities 'voice'. However, legislation altered the board of trustees' composition to give them more flexibility to respond to schools, parents and the community, while at the same time removing state control and intervention. The Sexton Report (1990), commissioned by the Business Roundtable, believed that the state should have no part at all in education unless it was absolutely necessary. Privatisation was the key to education meeting market demands (Barrington, 1998).

Ramsay (1993) identified two conflicting agendas between, on the one hand, the educators and the parents who sought a partnership approach in the 
interests of fostering equality, and on the other, by Treasury and business who wanted competition, choice and privatisation.

Initially the partnership agenda dominated but from 1990, when the National Government came to power, the market agenda flourished. The centrally mandated anti-sexist and anti-racist clauses were removed with Lockwood Smith, Minister of Education saying, "Gone is the politically correct warm fuzzy liberal social engineering of Marshall, Lange and Goff” (Barrington, 1998: 84).

The school charters, which had been seen as the "lynch pin under the education reforms, were no longer defined as contracts, or even agreements, but undertakings" (Snook et al, 1999: 31) through which the boards of trustees would undertake to meet their mandatory and non-discretionary requirements. The National Educational Guidelines, including the major curriculum requirements, could now be changed at any time without consultation, and other guidelines were introduced covering personnel, finance, property, enrolment and board meetings. These changes indicated a considerable increase in central ministerial authority. Barrington (1998: 87) provides an example of new ministerial power where "the Minister [can] remove a board of trustees in certain circumstances. School property management and development provides another example.”

According to Snook (1989), Nash (1989), Codd and Gordon (1991) these new changes all pointed to signifying power and control of education by the State. Codd and Gordon (1991: 32) concluded:

That a contractualist state, while distancing itself from civil society, actually increases its regulatory control and its power to shape political demands and manage economic outputs.

Subsequent developments have endorsed justification of those views. Rae (cited in Barrington, 1998: 87) identified five centrally driven developments impacting on schools in that year alone, including: 
The New Zealand Curriculum Framework, revised National Educational Guidelines, legislation for the Education Review Office, New Zealand Qualifications Authority (NZQA), accreditation procedures, and requirements of the Public Finance Act.

Other, more subtle, legal forms of control were also available to the central agencies. They could assert power over local bodies particularly if it was considered to be in the 'National interest'. These included, "legislation, regulations, gazetted statements, official announcements in the Education Gazette and administrative circulars” (Barrington, 1998: 88). The underlying justification for central agency control was because, as Rae (cited in Barrington, 1998: 88) explained:

That education equips future citizens and uses State funding, therefore any local or short-term practices or decisions, which might negatively affect individuals' life chances or the competitiveness or viability of the society needed to be prevented.

Within this statement, the tensions arising between market competition and the individual or local agency are clearly explicit. A second tension arose between education that was state funded and education that was privately/voluntarily funded. A third tension was with the boards of trustees who were responsible for adhering to the National Educational Goals and meeting individual and local needs, including acknowledging the place of Maori and the Treaty of Waitangi. Maori academic writers, Irwin (1999), Johnston (1997; 1998; 1999), Smith (1988; 1990; 1990a; 1991; 1997), Jenkins and Jones (2000), Pihama (1997) and Stewart-Harawira (1997) have criticised the 'new right' reforms for their lack of consultation, cultural insensitivity and the imposition of an unwanted Pakeha education system, while at the same time failing to enable Maori to develop and maintain their own culture as a democratic right. 
Pacific and other minority groups, which now incudes 'disadvantaged boys', have added their voice to the criticisms (Coxon and Mara, 2000; Alton-Lee and Praat, 2000). Jones (2000: 79) believes that the education reforms have led not to reducing the inequalities but instead "the term 'disadvantage' is losing 'its value' and with it the moral right to redress the inequalities.”

Arising from the above changes central government has been seen to retain significant powers in three ways. First, as a gatekeeper in controlling, for example, the opening and closing of schools; second, it has prescriptive powers where regulation determines standards for content, administration and management delivery; and third, through enforcement where the delivery of education is audited (Barrington: 1998).

Snook et al (1999) and Wylie (1999) found that the boards of trustees liked the status quo and while they wanted the government to give them more resources they did not want more responsibilities devolved to them. Wylie $(1997 ; 1999)$ reveals that about half of the principals surveyed thought that the relationship between the schools and the Ministry were as 'good' or 'better' than in the past. Over the past ten years, on average, 12 per cent of boards of trustees per annum have had difficulties with ERO. Wylie reported that it was not the same boards each year that ran into difficulties and that problems were resolved. Taken over a ten-year period, Wylie's report would suggest however, that most boards of trustees have had, at some time, a troubled relationship with ERO. Parental participation was found by Wylie (1999: 92) "to be further away than realised.” This may be attributed in part to external factors as referred to earlier but barriers do exist especially for Maori, the unemployed or those receiving a benefit. According to Wylie (1999: 92) "low decile schools and high Maori enrolment schools receive less community support than others, and most schools have not maintained the level of consultation with the community.”

\subsubsection{Unresolved Conflict between Central-Local Agencies}

During the period under review the tension between central-local agencies remained unresolved. Calls continued for privatisation, less state control and state provided education to be reduced or to be eliminated (Epstein, 1999). 
Decentralisation was seen to have had a paradoxical effect. Rather than the government devolving responsibility and power as first promulgated in 1988, there had been a tightening of control. While there was little overt and direct ministerial control, the effects of central agency control had become influential. At the same time notions of partnership, social justice and social equity had become subjugated to those of market values with educators, boards of trustees, parents and communities having 'no voice' to express dissatisfaction. The fiscal crisis became transferred into an educational one whereby the legitimation crisis was transferred downwards in the guise of freedom, choice, accountability, effectiveness, efficiency, excellence, equity, devolution/decentralisation and social cohesion.

\subsection{Summary and Conclusions}

The main thrust of the education reforms was to reduce the size of central bureaucracy and to convert each learning institution into a self-managing unit with its own elected board of trustees. Parents and communities were to be consulted and involved. There was to be an emphasis on partnership between the schools, the boards of trustees, parents, students and communities. Access to the Ministry of Education was via the Parents' Advocacy Board and Community Education Forums. The policies were legitimated through the rhetoric of individual freedom, parent power and consumer choice, and through which universal social goals of equality and democracy would be achieved. In short, the education reforms were to produce a closer match between schooling and society’s needs, especially economic growth.

However, over the 1988-1999 period the education reforms created unintentional, paradoxical, and contradictory tensions between educational ideology on the one hand, and neo-liberal ideology on the other.

Issues surrounding social justice, equality and democracy had become converted into narrowly defined 'scientific-technical rationality' issues. These in turn were technically measured or evaluated through central agencies who legitimated the educational content in terms of what was considered valuable 
knowledge, assessment and accountability. In so doing, they marginalised and alienated those who did not fit into the narrow education frames. 


\section{CHAPTER FOUR - CHANGING PATTERNS OF NEWSPAPER REPORTING IN NEW ZEALAND SINCE THE 1980s AND THEIR IMPLICATIONS}

\subsection{Introduction}

As discussed in chapter two, academic critics of the political reforms of the 1980s and 1990s argued that the thrust of these were consistent with a 'neoliberal' ideology; this ideology is interpreted to be reflective of Adam Smith's 'hidden hand' of 'free competition' leading to an increase in privatisation of public and private services. In keeping with the neo-liberal philosophy the education reforms were to be realigned so as to protect and to perpetuate the interests of the economy. Academic writers (discussed in chapter three) have argued that over the past decade unresolved issues remain and that only a small elite group has gained an advantage economically and educationally, which has been at the expense of the majority. As a result, they argue that the universal goals of equality and democracy have been seriously undermined.

This chapter focuses on some of the significant and important changes that occurred in New Zealand's print media during the neo-liberal reform years that recognised academic and professional writers have considered to be influential in bringing about such changes.

The print media and, in particular, New Zealand's five major daily newspapers is of interest because it provides accessibility and continuity over a long period of time. Unlike other media, for example radio and television, newspapers can be referred to at any time simply through the use of a library. Newspapers are ripe for the picking especially when measuring prominence at any given time (this will be explained in chapter five).

Specifically, this thesis is concerned with the role that the media played during the education reforms and poses two questions: 
1. Did the newspapers reflect the same issues as the critiques of educational policy changes written by academic and professional groups?

2. Did the public receive from newspapers the kind of coverage and analysis that would help them realise the significance of the education policy changes taking place?

In order to answer those questions it is necessary to discuss the role of newspapers. Therefore, this chapter looks at the changing patterns of newspaper reporting in New Zealand since the 1980s and their implications.

Apple (1982) believes that in order to understand how education and reproduction of the dominant culture occurs it is necessary to look beyond the classroom to analyse mass media, popular culture and the role of the arts. By understanding how they are linked, often by tacit means, and the relationship between them, it becomes easier to understand how the dominant culture remains dominant.

The changing ownership patterns of the 1980s has led to a decline in family owned newspapers as global ownership began to dominate the New Zealand mass media market. Writers such as Norris (2002) and McGregor (2002) see the implications of foreign ownership as having a negative impact on New Zealand's cultural integrity. They point to a loss of profits being reinvested within New Zealand because the profits go to overseas shareholders. In addition, critics see the possible political interference from foreign ownership as having the potential to abuse power, thus compromising New Zealanders' democratic rights (Kelsey, 1999; Norris, 2002).

In response to foreign ownership the role of the media has changed. Writers such as Curran (2000), Kim (1989), and Habermas (1984; 1987; 1989; 1992; 1996) believe the role of the newspaper is that of a watchdog. Ideally, the newspaper should act as a conduit in which its readers can form rational decisions, based on a wide range of diverse opinions, so in turn its citizens 
become emancipated within a democratic society. Critics believe the ownership changes have led to a 'dumbing down' of news content so now it has become merely 'infotainment' (Perigo, 2002; Edwards, 2002; Campbell, 2002; Bassett, 2002; Golding and Murdock, 2000). Consequently, the watchdog role, by a series of gatekeeping interventions, has seen to become muzzled (Lewin, 1984; Shoemaker, 1991; Schudson, 2000; Curran, 2000).

By gatekeeping, newspapers maintain the difficult role of reflecting both official and public opinion so as to remain commercially viable. Analysis of education content in New Zealand newspapers prior to the 1980s reforms has revealed that education, as a newsworthy topic, had low status in terms of frequency of news items. This was because they were of local origin and were likely to be consensual and not sensational (Cleveland, 1971; Roulston 1986). Overseas studies since 1988 (Kim, 1989; Bowers, 1988) support much of the earlier findings cited above.

Over the past decade only a few academic writers (Barrington, 1990; Codd, 1990b; Ramsay, 1993; Thrupp and Smith, 1999; Sullivan, 1999) have made reference to the media when they have been writing about the education reforms in New Zealand. Generally their comments have been negative. Parenti (1986) points out that there is considerable difference between the content of what academic writers consider important and those who write for newspapers. Each serves a different reader audience. How the content of newspapers comes to be printed and presented as 'reality' is discussed under the following headings:

- Ownership - changing patterns of the 1980s

- The role of the media

- News production - setting the agenda

- Gatekeeping

- Education content in New Zealand newspapers

- Summary and conclusions 
4.2 Ownership - changing patterns of the 80s

Up until the early 1980s consumer choice had been constrained by media oligopolies - where the media was owned and controlled by an influential few individuals or groups. Within the oligopolistic framework, Curran (2000:130) states that, "The press systems in most countries had developed a highly monopolistic form." This highly stable controlled media situation changed in the 1980s and 1990s by the diffusion of new communication technologies. Fibre optic cables, high-powered satellites, digitisation, personal computers and the internet offered new and faster communication links to the home. These new pipelines offered new opportunities to instant, faster and accessible means of communication, which affected the old oligopolistic control. This new form of communication introduced new sources of competition and, for a while, it looked as though the oligolopolistic market control had been broken, and the consumer would have choice and be empowered (Curran, 2000). In response to these changes the leading media producers launched what Curran (2000: 130) describes as:

A well judged combination of political lobbying and market adaptation. They pressed for a relaxation of anti-monopoly controls by arguing initially that market expansion diminished the need for regulation, and subsequently that concentration was necessary in order to compete effectively in the global market.

The success that greeted their efforts in many countries, including, crucially, the United States, enabled them to embark on an extended merger and acquisition spree supported by generous bank credit. Out of the fragmentation there developed a new pattern of multi-media concentration (Curran, 2000).

\subsubsection{Ownership in New Zealand}

Since the 1980s there has been a decline in influence from family owned media as global media companies began to dominate New Zealand's mediascape. According to McGregor (2002:14): 
New Zealand is unique in the western developed world for its laissez-faire philosophy about media ownership. Global media magnates such as Robert Murdoch and conglomerates such as CanWest cannot believe their luck. No cross-media ownership regulations, no prohibitions about vertical and horizontal ownership, no need to divest themselves of one outlet to buy another.

The newspaper industry in New Zealand is, according to Norris (2002: 36), “a duopoly, dominated by two foreign-owned companies - INL (Independent Newspaper Limited) and Wilson Horton.” During the period covered by this thesis INL owned four major dailies, including The Dominion and The Evening Post (these two Wellington papers merged during 2002 to become a morning paper and re-named The Dominion-Post). INL also owned The Press in Christchurch, The Southland Times in Invercargill and eight provincial dailies, and both Sunday papers. It was estimated, by the Audit Bureau of Circulations, that INL owned "about 64 per cent of the combined metropolitan, provincial and Sunday market” (Norris, 2002: 36).

Rupert Murdoch began his first overseas newspaper investment by acquiring 30 per cent of The Dominion in 1964 . He was subsequently restrained by the News Media Ownership Act 1965. However, by 1977 the Act was repealed and Murdoch continued to increase his hold.

Murdoch also acquired Twentieth Century Fox and Metro Media (television) and has well known sports interests across Europe, America, England, Australia and New Zealand, particularly through Sky (pay) television where he has a majority ownership and control. Early on, Murdoch realised that the way to achieve pay-TV was through sport, specifically mass football, where the viewers were willing to pay to see the games.

The second major owner was Wilson and Horton who published the largest daily paper, The New Zealand Herald. It also owned eight provincial dailies, including Hawke’s Bay Today, and several leading magazines including The 
New Zealand Listener and the New Zealand Woman's Weekly. Norris (2002: 38), using 2002 figures from The Audit Bureau of circulations, estimated Wilson and Horton's circulation to be "around 29 per cent of the combined metropolitan, provincial and Sunday market.”

Since 1998, "Wilson and Horton has been 100 per cent owned by interests associated with the Irish media mogul Tony O’Reilly, owner of Independent New and Media”(Norris, 2002:38). In keeping with the vertical, horizontal and cross-media profile, O’Reilly owns 66 per cent of radio networks in New Zealand. In addition to the communications ownership, Tony O'Reilly is chairman of US-owned H.J.Heinz, which also operates a chain of food stores within New Zealand under the name of Watties.

Kelsey (1999:195) believes this duopoly has a combined circulation of 92 per cent of the metropolitan and 81 per cent of the provincial markets. Murdoch controls 48 per cent of all newspapers with a circulation over 25,000, except The New Zealand Herald and The Otago Daily Times (Kelsey, 1999). According to Kelsey (1999:195), “Murdoch owns 70 per cent of the country’s newspapers, magazines and sports publications, as well as weeklies and both Sunday papers, and owned magazine distributions.” Murdoch and O’Reilly have been able to grow their empires partly by the demise of other, smaller publishers, and buying and selling assets after the stockmarket crash in 1987. Curran and Seaton (1988: 252) succinctly describe how such competition works and, paradoxically, leads to less competition when they say:

Successful publications have a built-in advantage over rivals because they have more revenue and generally lower unit costs, due to greater economies of scale. They are thus in a good position to consolidate their market lead by spending more on editions and promotional outlay thus weakening financially their rivals by encouraging them to spend more in an attempt to stay competitive. New technology does not alter the imbalance; nor undermine the incentive for chains to expand. 
Economies of consolidation make it advantageous for chains to buy up rivals, often at prices above the going rate and close them down. Therefore, deregulation enabled the financially stronger better-positioned duopolies/oligopolies to buy out less able or weaker, competitive media, which they either merged or closed down.

\subsubsection{Implications of Foreign Ownership}

Foreign ownership raises the question, does it really matter? Norris (2002) thinks that it does because foreign owners have no concern for the New Zealand national identity and culture. Consequently, overseas programmes and news can be imported, published, viewed or broadcast at very little expense because of the economies of scale and instant telecommunications. In a deregulated market, such as New Zealand's, there are no quota requirements thus issues relating specifically to New Zealand are more likely to be ignored. McGregor (2002: 9) suggests, "New Zealand is perhaps unique amongst the Western developed nations for its poor tradition of criticism and debate.” Thus foreign ownership only serves to exacerbate this situation.

The second issue, which arises from foreign ownership, is the destination of the profits. Does the money remain in New Zealand to be re-invested in the country, or does the money go to overseas shareholders? With deregulation it is estimated that about $\$ 4.7$ billion, that is, 75 per cent of profits from Telecom, have gone to overseas shareholders (Norris, 2002). In respect of the print media, figures are more difficult to come by. But an inference can be drawn that foreign investment is for commercial profit and capital growth.

\subsubsection{Implications of Cross-Media Ownership}

It is possible for some of the cross-media companies to merge. Norris (2002) points out, for example, that Murdoch's INL, who owns 66 per cent of pay-TV and 44 per cent print, was interested in merging the two companies together. Because New Zealand has no restrictions on cross-media ownership there is the risk of the abuse of the power of ownership (Parenti, 1986; Curran and Seaton, 1988; Norris, 2002). 
The only check New Zealand has against such mergers and potential abuse is the Commerce Commission whose role it is to ensure that competition prevails in all markets. But as McGregor (cited in Norris, 2002: 47) points out, "the provisions of the Commerce Act have been diminished over time, in a way that roughly parallels the increase in concentration of newspaper ownership." Furthermore, the Commerce Commission treats the different sections of the media differently and is therefore unlikely to exercise its power over such mergers (McGregor, 2002). Norris (2002: 47) concludes:

It is surely bad enough that three out five of the country's metropolitan dailies (reaching a majority of the country's readers) are in the Murdoch stable. If he were also to control not just a monopoly pay TV platform, but also a free-to-air network, the potential for the manipulation of public opinion, directly or indirectly, is an obvious threat to the democratic ideal of public exposure of a diverse range of opinion.

Murdoch, in particular, is well known for interfering with the print media. Kelsey (1999:195) notes, "Murdoch runs the worlds biggest media empire. He strongly defends his right to interfere in editorial matters, and sees it is his responsibility to do so.” This responsibility has extended to firing the reporters who wrote a critical report on the Monsanto Chemical Corporation (Norris, 2002); the stopping of Murdoch’s publishing company, Harper-Collins, from printing Christopher Patten's book on the hand over of Hong Kong (reportedly to protect his investments in China) and, the deunionizing of the Fleet Street staff in 1969 (Kelsey, 1999).

Murdoch is also known to cultivate connections in the political arena, not only internationally (Curran and Gurevitch, 2000), but also within New Zealand and, particularly during the last decade (Kelsey, 1999). O’Reilly has a reputation for being less interfering in politics and editorial policy and is thought to publish a broader range of opinion than INL newspapers. O’Reilly, like Murdoch, is no left-winger. At an elitist conference held in Queenstown Kelsey (1999:196) reports O’Reilly as saying: 
Looking at and participating in the miracle of New Zealand commerce, I have no doubt whatsoever that the next century will confirm what we already know - that New Zealand has found the economic way of fairness and transparency and a real return on capital; and that because of this, many others are in the process of finding the way to invest in this country.

Internationally Murdoch and O’Reilly are known for their neo-liberal ideologies, and there are no politically left wing media controllers to redress the imbalance (Curran and Gurevitch, 2000).

The increasing influence of the new duopolies/oligopolies has created many contentious debates among writers concerning the positive and negative implication of such empires for globalisation. Writers such as Frith (2000) and Dahlgren (2000) see this in a positive light. They see globalisation bringing faster and easier access to all forms of media to reach global, regional, national and local audiences. Neo-liberalists see this as having achieved their goal of the free-market model (Norris, 2002). Others have a deep concern for the loss of democracy.

While there has been greater access to the media not all have equal access. This has created a divide between the information-rich and the information-poor; an issue for politicians, the media and the public alike (Norris, 2002; Sreberny, 2000; Newbold et al, 2002). Diversity is reduced and specific cultures become lost or weakened in the globalisation of western culture. So attenuated are the weaker cultures that Srebreny (2000:114) calls the result a 'cultural bricolage' and in turn this has led to an unequal distribution of power in the global economy (Regus and Roman-Velazuez, 2000). Democracy therefore is at risk, not only from inside New Zealand, but also from globalisation.

\subsection{The Role of the Media}

With the changing political, economic and communication transformations that occurred through the 1980s and 1990s there has been a corresponding change in the role of the media. So significant has been the change that Curran 
(2000:120) suggests, “The literature on the media and democracy need a removal van to carry away the unwanted lumber accumulated over the centuries.”

At a basic level the function of the mass media is primarily communication at societal level of news and information. Laswell (cited in Kim, 1989:11) believes that:

Mass communication is purpose or goal oriented, and that its goals can be seen from two points of view: the communicator's and the receiver's. The goals of the communicator are to inform, to teach, to persuade and to please the public. The goals of the receiver are to acquire information, to reach decisions and to enjoy.

In this role newspapers provide a public forum and a public service, connecting isolated and segregated groups with the central values and information that enables society to serve its purposes. It is because of this governing process that the press is referred to as 'the Fourth Estate'.

Habermas's 'public sphere' (1989) believes that in an ideal situation, communication systems would contribute in two ways. First, the systems would provide access to information, advice and analysis that would enable the public to know their rights and to pursue them effectively. Second, the systems would provide the broadest possible range of information, interpretation and debate. This would enable the public to exercise their choice, to register dissent and to propose alternatives. Such a two-way process would enable the public to form rational opinions so as to become emancipated within a democratic society.

In a democratic society Curran (2000) sees that the role of the media is to act as a public watchdog by keeping an eye on the state to expose abuses of official authority. The watchdog role was, and is, to override all other functions of the media. Therefore, neo-liberalists have argued that by anchoring the media to the free market it is possible to ensure that the media has complete 
independence. Should it be subject to public regulation then this all-important watchdog role would become muzzled or "transform into a snarling Rottweiler in the service of the state" (Curran, 2000:121).

Within a watchdog perspective there is the underlying assumption that democracies need informed and participant citizens. There is also the belief that public debate is more likely to produce rational and just outcomes when different views and interests are taken into account. At the heart of this is the belief that active self-determination, reasoned debate and social inclusion are the foundation stones for a healthy democracy (Habermas, 1984; 1987; 1992; 1996).

However, Parenti (1986), McGregor (2002), Curran and Seaton (1988) and Curran (2000) argue that the watchdog role fails within a neo-liberal economy. Firstly, they believe it restricts the effective freedom to publish. In theory anyone can establish a publishing company but, because of the economies of scale, it is almost impossible to enter the mass communication market because of the high cost of entry.

Secondly, the free market reduces the circulation of the public information and so readers become less informed. Ownership changes have influenced the structure, content and news being gathered from a variety of sources (discussed later).

Thirdly, the role of public debate has been restricted. Curran (2000) and Norris (2002) see an ever-increasing gap between an 'information-rich' media for elites and an 'information-poor' media for the general public. The result is polarisation, which only serves to reflect and perpetuate inequalities in society.

Fourthly, the market is seen to undermine intelligent debate (Perigo, 2002; McGregor, 2002; Curran, 2000; Golding and Murdock, 2000). Edwards (2002) sees much of the news presented on TV as 'cootchie coo' news. Sharing the same view is Perigo (2002) who believes there has been a trend over the past ten years toward 'dumbing down' of intelligent news content aimed at the 
under-40 age group. While these comments relate to the TV news it has relevance to newspapers because newspapers support TV personalities who deliver the 'cootchie coo' news. Edwards (2002) gives the example of letters and articles published in the national dailies throughout New Zealand when the TV-one newsreader, Richard Long, was to be replaced by the 'more charismatic and expensive’ John Hawkesby. According to Edwards, breaking 'the marriage partnership' of Richard Long and Judy Bailey was tantamount to a 'divorce', and the public responded by turning to the press to protest at the change. Apparently the public liked the 'cootchie coo' arrangement.

Newspapers are seen to have a similar content (McGregor, 2002). Television presenter, national broadcaster and writer John Campbell (2002) describes the 1990s period as failing to report alternative perspectives. It was only after reading Pilger's books did Campbell come to realise the narrowness of reporting in New Zealand during the past ten years when the constant acronym TINA (There Is No Alternative) was very much in favour. While Campbell thought journalists had been unquestioning of the neo-liberal policies during this time, political historian and former MP Michael Bassett (2002) holds the opposite view. He considers few reporters step outside the narrow left comfort zone and writes in The Dominion Post (2002, August 20: B4):

Editorialising on political matters by know-nothing suburban reporters makes our throwaway papers toxic to fish and chips... Reciting mantras about the evils of the market, as all too many journalists do, belittles them rather than informs us.

Bassett (2002, August 20: B4) does not hold journalists wholly responsible for this state of affairs, indeed he has considerable sympathy for them when he says:

To be fair, neither journalists nor their superiors should bear full responsibility for poor or slanted reporting. Too few classrooms deal with current events. My own profession has downgraded political history while elevating gender and ethnic stories. Some 
political scientists nurture quaint theories. Short specialist courses can't make up the shortfall. The financial pressure applied to the media by demanding shareholders has pruned staff members. Wage structures make it difficult to retain good reporters when nearby PR companies offer double remuneration. As a result, overworked journalists easily succumb to spoon-feeding.

Curran (2000) too sees the dumbing down of news as a product of the commodification of information. As a consequence, Curran explains that news has become, "market oriented so that news becomes simplified, personalised, decontextualised, with a stress on action rather than process, visualisation rather than abstraction, stereotypicality rather than human complexity" (Curran, 2000:129). Curran and the above writers believe that the news content has become superficial, narrow, unquestioning and ill-informed largely due to the commodification of information coming from the media over the past decade.

\subsubsection{Voice of the People}

Representing people to authority is a key democratic function of the media. That is, the media speaks for the people (Curran, 2000). After informing its citizens and having held a debate, the media, acting as a watchdog, relay the public consensus that results from the debate to Government. Carlyle (cited in Curran, 2000:129) believes, "The press is a power, a branch of Government with an inalienable weight in law making, determined from the will of the people”. The fundamental assumption is that, "the broad nature of the press is ultimately determined by no-one but its readers” (Whale cited in Curran, 2000:129). The argument being that the press must, in order to remain competitive in a market driven economy, print what the public want, and by extension, the press speaks for the people.

However, the influence the reader has is reactive rather than proactive in the choice of available newspapers and the content that is published within papers themselves. Some of these factors reducing reader influence have already been referred to: the concentration of private duopoly of the media ownership with 
their influence resulting in censorship and suppression of the news; the high entry cost of setting up newspapers; and the 'dumbing down' of news. Critics believe these factors have contributed to the weakening link between public opinion and the media that used to exist.

Another limitation of the consumer influence on newspaper content applies to minority groups and those with the least money. Mass media markets aim at economies of scale to maximise sales and are therefore aimed at a majority market. Minority and lower income groups have reduced choice, access and influence in media content.

Advertising further distorts consumer influence from the funding of “television, magazines and newspapers, which exerts a gravitational pull towards upscale, profitable audiences” (Curran, 2000:132). Some critics see the power and influence of media, including advertising, as 'propaganda' (Herman and Chomsky, 1988). Golding and Murdock (2000:74) describe advertisers as, "operating as latter day licensing authorities, selectively supporting some newspapers and television programmes and not others.” Although advertisers can withdraw their support, Gans (cited in Parenti, 1986: 49) found:

\footnotetext{
National news advertisers usually did not cancel advertisements in the news media. The only time that advertisers are likely to withdraw their financial support is when a paper becomes too heterodox.
}

Consequently, advertisers exert considerable influence over newspaper production, control and viability. Stepping out of line because of heterodoxy, that is, unaccepted or unorthodox newspaper practices, and the subsequent loss of funding reinforces consensus within the newspaper industry.

Habermas (1992) sees the 'public sphere' in a much wider context. He believes it is, "a highly complex network that branches out into a multitude of over lapping, international, national, regional, local and subcultural arenas” (Habermas, 1992: 373). Such globalisation of communication can transcend 
national barriers, which can bring political pressure on governments. Areas in human rights, environmental pollution, global market regulation, alleviation of poverty, and world peace are such examples (Curran and Gurevitch, 2000; Newbold et al, 2002).

Globalisation however, can, as discussed earlier, serve to weaken national, local and subcultural links and create greater inequalities of power and resources. Researchers have identified a paradox with increasing globalisation - that of shrinking news coverage of foreign and international events. As a result, Van Gompel et al (2002: 202) concludes, "the media are swamped by entertainment and commercialism, thus undermining the myth of their central democratic role.” Thus the watchdog role the news media is expected to play has been seen to become 'muzzled' with the changes during the 1980s and 1990s. But duopolies/oligopolies cannot survive and thrive alone. To remain commercially viable they need to have support from others. News production plays a crucial role in maintaining their commercial viability.

\subsection{News Production}

At an elementary level, journalists write words that are published in newspapers. Journalists make the news and act as conduits. They stand between significant information and the public's awareness of it. What they report impacts on public knowledge and perceptions. Morrison (2002: 57) sees journalists as being:

Self-appointed arbitrators of what people get to know about through the mass media, and the way that information is couched. They claim to be trained and experienced in distilling "the new of the day". They are in command and control of a process that plays a part in shaping public life. They are in a position of power because they have an outlet; a newspaper, radio or television station to create and disseminate the news. 


\subsubsection{Journalists}

The stereotypical image of journalists being old hacks is outdated. Journalists in New Zealand are, according to the last Journalist Training Organisation Survey 1994 (cited in Comrie, 2002:165), “overwhelmingly in their twenties and thirties.” Anecdotally, Comrie suggests that journalists leave the profession a few years after training and turn to Public Relations (PR) where the salary and conditions are better. Graduate journalists from various universities and polytechnics are considered to be better educated, "even before they are initiated into the mysteries of the craft" (McGregor, 2002: 7). Tucker (Mediawatch, July 15, 2001) thought our journalists to be 'pretty sharp'. Tucker noted that through the 1990s they, along with Australian journalists, were recruited by Murdoch to the United States to train journalists because of their high standard.

In political journalism women now represent about 50 per cent (Riddell, 2002: 205), however, there are no figures on Maori, Pacific Island or minority journalists. Unlike overseas journalists, where many are found to be cynical (Kovach and Rosenstiel, 1999), New Zealand journalists tend to be more pessimistic (McGregor, 2002). McGregor (2002: 7) believes New Zealand journalists are "working through a crisis of faith" because of the battering they have experienced over the past 10-15 years. As discussed earlier not all commentators are impressed with the last decade of journalism. These critics however, have seen influences beyond the immediate journalists' control leading to poor reporting.

Like their overseas counterparts, New Zealand journalists are considered to be upper middle class and share the same homogenous social backgrounds and personal values of media personnel. Lichter, Rothman and Lichter (1986) found that in their survey journalists were more likely to have grown up in cities, come from white middle class homes and to have well educated parents whose values are socially liberal but, if translated into New Zealand's terms, are economically conservative. 
Advocates, who suggest the hiring of more women and minority groups, believe this would bring about new practices and transform the product itself by making newspapers more representative of the population. This reduces the criticism that journalists lose touch with their reader audience (Parenti, 1986; Schudson, 2000; McGregor, 2002).

However, Schudson (2000: 86) notes research shows that:

Despite different national cultures, despite different patterns of professional education, and despite different labour patterns, the stated professional values of the journalists do not differ greatly: whoever they are, they will be socialised quickly into the values and routines of daily journalism.

This results in 'pack journalism' (Schudson, 2000) where journalists write very much from the same perspective. This shared professional culture has become bureaucratized not only locally, but also internationally, and has been named by Gurevitch, Levy and Roeh as ‘the global newsroom’ (Shudson, 2000:187). Such uniformity contributes to gate keeping (discussed later in this chapter).

Even before a journalist arrives at an assignment decisions have been made by others. There is a chain of command. Editors and chief reporters decide what is newsworthy. They can cut, re-write or 'kill' a story. Journalists who have been socialised into newspaper culture anticipate what to write, and so a form of self-censorship prevails (Parenti, 1986). Gans (1979: 254) notes, "that self censorship can be also unconscious in which case journalists may or may not be aware they are responding to pressure.”

Censorship can extend to the editors and chief reporters. Top executives meet with editors weekly or daily to keep an eye on things. Top executives are seen to have unlimited power but do not exercise power on a day-to-day basis (Parenti, 1986). In turn the top executives are also subjected to the judgements of the ruling corporate directors whose influence has been discussed previously. 
Bagdikian (cited in Parenti, 1986: 44) concludes:

In the real world of the newsroom and boardroom the news is fiddled with by management either crudely through direct intervention or more subtly by picking editors who know what is expected of them.

In addition to the ideological and informational constraints imposed by the media executives and owners there are the advertisers who also influence media content. Hence the media executive chiefs internalise their judgements that determine what is presented as news of the day. The question of how they make those decisions and on what basis forces journalists:

To confront their prejudices, biases, views and personal interests, their inevitability limited view and experience of the ethnic, cultural and socio-economic mix of the community in the area they report, and the social and institutional forces that have shaped their own values (Morrison, 2002: 59).

While journalists are expected to meet their institutional, corporate and commercial interests they are also expected to report on a credible story based on sound theory and ethics. Fundamental to journalist methodology is 'objectivity'. Objectivity implies neutrality, the truth (Lichtenberg, 2000) and reassures readers that the news is not from a journalist with an agenda and personal views. In short, objectivity gives "quality value to the news article" (Morrison, 2002: 59). Journalists believe if they stick to the hard facts of what, where, why and who/whom they will maintain objectivity. But as Lichter, Rothman and Lichter (1986), Lichtenberg (2000) and Morrison (2002) point out, facts and the like do not occur in a vacuum. To appear 'objective', valueladen comments are often sourced to someone else. This can personalise and concretise the news rather than focusing on abstract ideas and issues.

Lichtenberg (2000) and Morrison (2002) believe that such pursuit leads to dishonest practices by putting the words into someone else's mouth. Journalists refer to this as "rent a quote” (Morrison, 2002: 66). Such objectivity distorts 
the fairness and balance. How much should be reported and what to discard are judgements made by journalists and are therefore subjective. Rather than having a false dichotomy between objectivity and subjectivity, Lichtenberg (2000) and Morrison (2002) believe it is preferable for journalists to recognise their value judgements and that they should be prepared to defend them.

\subsubsection{News Sources}

Traditionally, journalists have depended largely on interviews, documentary resources, for example, company annual reports, council minutes, and press releases from Parliament, the courts and sport. Journalists also rely on, for example, reference books, and computer databases and microfiche records (Tidey, 2002).

During the 1990s a new influence arose in the form of Public Relations (PR). “There are an estimated 1,500 government and non-government PR professionals in New Zealand" (Tidey, 2002: 76) who have gained the reputation as 'spin doctors'. Macnamara (cited in Comrie, 2002:159), “defines a spin as the slant that is given to a news item - usually for political purposes. Hence 'spin doctor' - the PR person who is responsible for the spin.”

Sumpter and Tankard (cited in Comrie, 2002:159) argue that spin-doctors have:

\footnotetext{
A genuinely new communication role that differs from conventional PR by putting greater stress on personal contacts with the media, by attempting to intervene earlier in the news making process, by using new technology to greater advantage, and in other ways.
}

Not all agree with this type of news management. McGregor (cited in Comrie, 2002: 159-160) describes this type of communication as creating, "an invasive creeping condition [so much so] the media manipulators have become integral to political communications and employ sophisticated strategies to 'spin' the news." So entrenched has this method become that Stauber (cited in Tidey, 
2002: 77) believes that today it is, "the means by which the vested interests who can afford PR - governments, politicians and big business - maintain their power over us." Schudson (2001) estimates that in America 30-60 per cent of the news is generated from PR agencies. In New Zealand, Bartley (cited in Comrie, 2002: 163) found that:

Over a two-week period 47 per cent of stories in the business pages of the five metropolitan dailies were based entirely on press releases, while a further 24 per cent were press releases that had been modified and added to by journalists.

While there is no comparative historical analysis on the growth of PR in the media Comrie (2002:163) says that, “Anecdotal evidence in New Zealand suggests there has been a quantum leap in the amount of such activity in the last decade." The growth of the public relations sector has impacted on the media at a time when there have been cutbacks on journalists in the news media. Comrie (2002:163) describes the loss as, “A bleeding of journalistic expertise from news media major papers.” As evidence, she points out that major papers have closed while other newspapers have merged, for example, The Evening Post with The Dominion (July 2002); and the Hawke's Bay Herald Tribune and the Napier Telegraph renamed Hawke's Bay Today in 1998.

Further constraints have been identified by McGregor (2002:10) where she describes time, now influenced by 'warp speed', as being the casualty of new technology giving little time for reflective journalism and the newsrooms as being, "Lean-to-the-point-of-emaciation.” This emaciation has impacted on the newsroom culture to such an extent that it has had a negative influence on the news media. With the changes there has been a move in the balance between moral, social and commercial considerations. McGregor (2002:10) believes that, "Journalism exists unhappily with the balance of the business tipped toward marketing, audience expectations, ratings, circulations and entertainment.” 


\subsection{Gatekeeping}

Regardless of the sources of information it is apparent that a method of gatekeeping is used at all levels of news processing. Gatekeeping was a term first coined by Kurt Lewin, and several other social scientists (White, 1950; Gieber, 1964) applied it to journalism. Lewin (1984:162) first described the gatekeeper's function as being where:

Gate sections are governed either by impartial rules or by "gatekeepers"; and in the latter case an individual or group is "in power" for making the decisions between "in" and "out”.

Shoemaker (1991) and Curran (2000) not only see the concept as useful but also extend its usage to include the neo-liberal duopoly/oligopoly frameworks which have, in effect, become 'super gatekeepers', and as such are seen to have considerable influence on newspaper production. But as Norris (2002: 47-48) notes, "little, if any, analysis has been done on the changes in content within New Zealand newspapers since the 1980s consolidation began in earnest.”

Before the changes of the 1980s and 90s, Cleveland's study (1971) on subject content analysis of the New Zealand press, found that the New Zealand Press Association (NZPA) prescribed and provided the bulk of news, in fact 80 per cent in some cases. One of the highest internal news generating topics was the human interest and social affairs sections (under which education topics were categorised) with 76 per cent coming form NZPA. Some twenty years later, Harbridge (1983) reached a similar conclusion in an industrial relations paper in which he described the consistency of approach as suggesting a 'conspiracy'. Collectively the non-NZPA and NZPA human interest and social affairs sections were found to make up 18 per cent of all final news items. Specifically, “education items represented 1.82 per cent of all new items" (Cleveland, 1971:13).

Closely associated with the above gatekeeping methods is the use of the Budd score (explained in the next chapter) in which articles are scored 0-5 according to their page position on a newspaper. The more prominent the article, the 
higher the score. Educational items have, historically, low Budd scores usually in the 0-2 score range (Roulston, 1986). Educational items were found to be low status in terms of frequency, being of local origin and therefore likely to be consensual and not sensational. The gatekeeping method was found to be a very effective way of presenting what the public wanted while still remaining commercially viable.

Since the changes of the 1980s' newspapers have had to adopt a more commercial approach to selling papers. Editors, chief reporters and news chiefs have developed a heightened sense of a 'news reader audience' in terms of what sells based on circulation figures which have become highly competitive. Circulation peaked in the early 1990s and since then there has been a steady decline nationally from one million copies sold daily in 1989 to 750,000 in 2001 (Boyd-Bell, July 15, 2001). The Evening Post, for example, had a 92,000 circulation in 1979 and by 1990 its circulation had dropped to 56,000 largely because of the competition from the city’s morning paper, The Dominion.

Circulation is made up of regular subscribers (approximately half of all sales) with the other half coming from newsstands. Therefore, the front page above the fold line of the dailies becomes a marketing tool. Editors aim to make it look as dramatic and as interesting as possible so as to catch the passer-by (Boyd-Bell, Mediawatch, July 15, 2001).

Journalists now look for trends and aim for a 'personal angle' with an increased appeal to women readers who have been identified as having 70 per cent of the buying power (Mediawatch, October 6, 2002). To tap into this potential market, papers now focus less on politics and more on family issues, schools, entertainment, sport, arts and local news. Fred Tulloch, Southland Times Editor (Mediawatch, October 6, 2002) believed that local news was seen to be more important than national events. For example, Tulloch saw the America's Cup as being a North Island event rather than a national event and, unless New Zealand retained the cup, The Southland Times would not publish much about it. Interestingly, in the same interview, all three editors from the South Island major dailies shared the same view. 
The Southland Times (Invercargill), The Otago Daily Times (Dunedin, and the only independently owned New Zealand major daily newspaper), and The Press (Christchurch), wanted the North Island newspapers to publish more about events that occurred in the South Island. Furthermore, they would like the North Island to have less of a 'time-lag' when they did publish news from the South Island. All three editors believed the news media in the north is not interested in South Island news. They believed it was a 'numbers game', with a third of the population living in Auckland and approximately three-quarters in the North Island (Mediawatch, October 6, 2002). The North-South Island division is not a new phenomenon. Roulston (1986) found that a time lag and the publication of different news items between the two islands, existed nearly twenty years ago. It is interesting to note that under different ownership the problems still persist.

Murdoch's papers (The Press, The Southland Times, The Dominion and The Evening Post) run to a 'qualipop' formula where there is populist appeal on the front page and more serious issues on the inside (Pankhurst, Mediawatch, July 15, 2001). The result has led to a conundrum between newsworthy stories compared with what readers want. The bottom line is to entertain and inform (infotainment) which has a mixed response from journalists (Mediawatch, July 15, 2001).

\subsubsection{Editorials and Letters}

Editorials are read by ten per cent of the reader audience. Journalists refer to them as the ' $A$ ' readers. These readers are considered to be "people of influence and editorials are aimed at this ten per cent” (Zavos, Mediawatch, September 16, 2001). Therefore, the editorial section by its intent is not aimed at the majority of readers. This, however, does not stop readers from having an opinion, which, in theory at least, can be expressed through the letters to the editor column. Editors, however, have the prerogative to gatekeep on the grounds of fairness and balance. The New Zealand Press Council Statement of Principles 1999 (cited in McGregor, 2002:155) says: 
Letters - selection and treatment of letters for publication are the prerogative of editors who are to be guided by fairness, balance, and public interest in the correspondents' views.

Letters have been known to manipulate the news media and cultivate allies to act as lobbyists and spokespeople in its interests (Tidey, 2002). A well known example is that of the Timberlands logging operation, where Hager and Burton (cited in Tidey, 2002:77) revealed that:

\begin{abstract}
Most letters to the editor in favour of logging could be traced straight back to Timberlands and its PR firms. Nearly all voices speaking publicly in favour of logging turned out to have been orchestrated by Timberlands and nearly every news story sympathetic to Timberlands was revealed to have been arranged by the company.
\end{abstract}

Letters to the editor in this case were only part of the lobbying. The manipulation of the media also included targeting sympathetic journalists and editors to publish the client in the most favourable light. Such tactics are not, according to Rennie QC, considered to be unethical. It is the responsibility of the journalists to check on their sources (Tidey, 2002).

Letters to the editor addressing education concerns were found to have very low frequency. Roulston (1986: 53) found in the period from 1978-1982 that only three letters had a high Budd score addressing issues about education. Roulston (1986) believed that while the public was better informed than in the past their response, as measured in the newspapers, was one of indifference.

Letters on the whole are largely seen to reflect the values of the newspapers. Being guided on the basis of fairness, balance and public opinion, has been found to reflect the editor's view, leading to a relatively narrow range of views and themes being published (Parenti, 1986; Roulston, 1986). 


\subsection{Education Content in New Zealand Newspapers}

The content of newspapers written with a reader audience in mind differs from those writing academic articles for an academic audience (Parenti, 1986). Norris (2002) has acknowledged little, if any, content analysis of newspapers has been done in New Zealand since the neo-liberal changes were introduced in the 1980s and 90s. Content analysis of education as reported in newspapers has also been neglected. Equally there is little overseas research on newspaper reporting on education reform during the same period of time.

Kim (1989) found that the extent of news coverage in five major daily newspapers in Connecticut differed substantially in terms of quality and quantity. Most of the news on education was locally orientated "with a heavy emphasis on the financing of local public schools" (Kim, 1989: 83). Much of the news about education was event oriented rather than issue oriented.

Kim also found that the reporters covering educational issues saw their role as worthwhile. "They were responsible for informing the reader audience of important information. Most planned to move up to 'general-beat' assignments” (Kim, 1989: 84). Overall the reporters were found to be entrylevel who did not have any expertise or experience in education. Therefore, the wider implications of the education reforms eluded them.

Bowers (1988) examined the influence of newspapers on public opinion during the 1980 education reforms in Texas. Bowers (1988:160) found that, "The media quoted more frequently and favourably those groups who favoured education reform.” Bowers (1988:160) suggested, that "the media, in a state in which elite dominated politics is important, is a means by which the elites can communicate.” He found there were very few critical individuals to influence or to resist such changes. The closer the individual was to the core elite the less critical they were of the education reforms. Those who were critical and opposed the reforms "received harsher treatment in the newspapers" (Bowers, 1988:162). 
In New Zealand a few academic writers have made passing reference to the media over the past tens years when discussing education reforms. Their passing references are, without exception, negative. According to Barrington (1990:199):

Constant media attention focused on the apparent inability of the existing system to deal adequately with such issues as the high number of poorly educated and unemployed school leavers (as if schools created unemployment), and education differences in the academic performance of Maori and European schools leading to increasing disaffection by many Maori.

Thus the media were seen to be paving the way for acceptance of the reforms based on the fear that education was failing school leavers, particularly Maori, who could become disaffected. The inference being that civil and racial unrest could follow, with the addition of the financial cost (burden) on the already cashed strapped taxpayer to pay for unemployment benefits.

However, Codd (1990b) held a different view. He saw the media's reporting of the Picot reforms as:

The staging of a highly managed media event to promote an official report on education [that] was unprecedented. Teachers and the public were 'persuaded' by a skilfully orchestrated media presentation that the major Picot proposals were both necessary and beneficial (Codd, 1990b: 201).

Grace (cited in Codd, 1990a) argued that the educational principles that had been established by the first Labour Government, and that had subsequently reflected the New Zealand school system for generations, had been challenged to the point of crisis with the new education reforms. This challenge, Grace (cited in Codd, 1990a: 17) argued, was: 
Mounted by four 'socio-political' agencies: the New Zealand Treasury, the National Party, the mass media, and the Business Round Table. With these 'unholy allies' lined up on one side, and the educational establishment on the other, the government of the day was compelled to react to the ensuing crisis by attempting to forge a new settlement.

Therefore, the media are seen to be supporting the neo-liberal policies, which influenced the government to respond to the pressure it was being put under. A different view was provided by Ramsay (1993) who thought the public throughout the restructuring process, initiated by the Picot Report, had been 'fed a diet of negativity'. Specifically Ramsay (1993: 270) believed that:

For eighteen months in connection with education, television, radio and the print media seem to have delighted in reporting on schools with financial difficulties, on trustees in conflict with teachers, on disenchanted Boards of Trustees' members resigning, and on overburdened principals leaving the teaching profession.

What surprised Ramsay was, given as he saw it, the media's role as being only interested in disasters, how few cases concerning the education reforms were reported. He believed that while problems did persist they were being addressed and fears concerning the education reforms would be unfulfilled.

Academic and professional writers however, have identified ongoing problems stemming from the education reforms (discussed in chapter three) and have written about them at length in academic publications. A decade after the reforms some academic writers consider the media to portray educational professionals in a negative light. Over the past ten years teachers have, for example, according to Sullivan (1999:144), "taken a battering both in the press and by the slow and inexorable build up of anti-teacher legislation and regulations which inherently deny their status as professionals.”

The delegitimisation of their professional role is also found in other ways in which the media reports on education. Since the early 1990s, Education 
Review Office (ERO) reports have been published in the national daily newspapers. Thrupp and Smith (1999) have questioned the usefulness of such reporting. They believe (1999) that such reporting is less concerned with the improvement of individual schools than the desire to inform or shape public or consumer opinion and expectations of schools. Presumably the possibility of such publication also acts as an incentive (to use the NPM framework) to other schools to ensure their own house is in order before an Education Review Office review.

Whether or not such reporting does have the effect ERO wants is a moot point. Wylie (1999) found, according to the principals she had surveyed, that such reporting had had little impact on schools. Even negative ERO reports printed in newspapers seemed to have had little impact on the schools concerned. However, the perception remains for academic and professional writers that education is negatively reported and as a result, the news media do not print a fair and balanced view.

\subsection{Summary and Conclusions}

The changing role of the media brought about by overseas foreign ownership has been seen by some critics to distort public debate by narrowing the issues, which Habermas $(1984 ; 1987 ; 1992 ; 1996)$ describes as being 'technicalproblem' solving in nature. Critics argue that by adopting such a stance the media, using a series of complex gatekeeping controls, undermine the very preconditions necessary for effective rational communication, and the emancipation that underscores a democratic society. Consequently, communication goes in one direction: from the printed page to the reader audience. The reader audience is reactive rather than proactive and has little real opportunity to respond in a meaningful way. Habermas describes this as colonisation of society's life-world which he considers to be the proper home of communicative rationality. Colonisation occurs through the private ownership of newspapers in which market forces (power and money) expect 'objective' reporting so as not to offend (and possibly lose) readers. Thus the watchdog role the newspapers purport to play has come under considerable criticism from elsewhere in the media and by some educational commentators 
because, in their view, newspapers have failed in their role and so have undermined the very fundamental tenets of a democratic society. It is in this context that this thesis seeks answers to the questions raised at the beginning of this chapter. 


\section{CHAPTER FIVE - METHODOLOGY}

\subsection{Introduction}

The purpose and structure of this chapter describes the content and the research method used to answer the questions this thesis has posed. This chapter discusses the mixed research method chosen under the following headings:

- Two major research paradigms - covers the distinction between quantitative and qualitative paradigms

- Mixed method approach - discusses the effective use of combining both quantitative and qualitative paradigms

- The use of mixed methodology for this research - covers the rationale for choosing such a methodology which blends quantitative and qualitative approaches

- Phases of the research - covers the procedures for the collection, analysis and interpretation of data

- Validity - covers the 'fitness for purpose' of using a mixed research methodology

- Reliability - covers the consistency and dependability of the data covered

- Ethical considerations - covers the ethical responsibilities required of this thesis

- Summary - draws together the salient points covered in this chapter

\subsection{Two Major Research Paradigms}

Research approaches have been typically divided into two broad philosophical approaches. The first is known as 'Positivistic' or 'Normative' (ontological/quantitative) approach, while the second approach is known as ‘Anti-positivistic’ or 'Interpretative’ (epistemological/qualitative). Historically, there have been deep divisions to the concept of social reality between the two broad philosophical paradigms (Cohen et al, 2000). This section will discuss the two approaches and the criticisms arising from them under the following headings:

- The Positivist approach

- $\quad$ The Anti-positivist approach 


\subsubsection{Positivistic Approach}

This paradigm is seen as being "Stable, observable and measurable” (Merriam, 1998: 4) and has its origins with the ancient Greeks. However, this approach is more associated with the nineteenth-century French philosopher, Auguste Comte, who "was the first thinker to use the word [positivistic] for a philosophical position” (Cohen et al, 2000:8). Comte’s view led to a general doctrine of positivism that "Genuine knowledge is based on sense experience and can be only advanced by means of observation and experiment” (Cohen et al, 2000:8). Within this paradigm, the social scientist, as a researcher, is viewed as an "objective" observer, rather than a "subjective" participant in social reality (Cohen et al, 2000). The end product of the research parallels those of natural science and the analysis reflects the "laws or law-like generalisations that have been established in relation to natural phenomenon" (Cohen et al, 2000:8-9).

Typically, this scientific line of inquiry relies on observations that have been formulated into hypotheses, which may have had its origins in previous research. Within the research paradigm, variables are identified, defined and an experiment is designed and tests conducted. The data are then analysed for patterns and relationships, hypotheses are tested and explanations given. In turn, theories are revised or developed in light of the law-like generalisations that have been made (Hall, 2003).

\subsubsection{Criticisms of Positivism}

However, in the second half of the nineteenth century other philosophers, scientists, social critics and poets reacted against such positivistic philosophy claiming that it "Undermined life and mind" (Cohen et al, 2000:17). William Blake, the poet, saw the universe "not as a mechanism but as a living organism” (Cohen et al, 2000:17); Kierkgaard, the Danish philosopher, saw the meaning of existence as "Concrete and individual, unique and irreducible, not amenable to conceptualisation” (Beck cited in Cohen et al, 2000:17). Kierkgaard (Warnock cited in Cohen et al, 2000:17) thought: 
Subjectivity and concreteness of truth are together the light.

Anyone who is committed to science, or to rule-governed morality, is benighted, and needs to be rescued from his state of darkness.

Habermas also thought the normative approach had a dehumanising effect. He believed that the positivist's need to control put more open-ended, creative, humanitarian aspects of social behaviour at risk (Cohen et al, 2000).

Furthermore, the narrow view of knowledge held by positivists equated only with scientific knowledge and therefore neglected hermeneutic, aesthetic, critical, moral, creative and other forms of knowledge. This in turn, "silences an important debate about values, informed-opinion, moral judgements and beliefs" (Cohen et al, 2000:19).

The fundamental difficulty with positivism is that it regards human behaviour as passive, essentially determined and controlled, therefore it ignores human intention, individualism and freedom (Cohen et al, 2000).

\subsubsection{Anti-Positivism}

The above criticism, along with the rise in social sciences, led to what is known as qualitative research. 'Qualitative' is an umbrella term that covers interpretive, constructuralist, naturalistic and postmodern approaches to research (Creswell, 2003). Qualitative research sees reality as being "Wholistic, multidimensional, and everchanging” (Merriam, 1998:6). Characteristically qualitative research emphasises the perspective of the participants with a focus on natural settings (as opposed to controlled experimental environments), and relies on participants' descriptive reality.

This research paradigm originates essentially from three theoretical frameworks, phenomenology, ethnomethodology and symbolic interactionism. Although the three frameworks differ from one another they share many common assumptions which can be summarised as follows (Cohen et al, 2000): 
- People are deliberate and creative in their actions. Their actions are intentional

- People actively construct their social world

- Situations are fluid and changing and are therefore not fixed

- Events and individuals are unique and are therefore, not generalizable

- Humans should be studied in their natural state rather than in a manipulated or controlled environment

- People interpret their contexts and events, therefore there are multiple interpretations

- Reality is layered and complex and not reducible to simplistic interpretation

- Humans, including researchers, are part of this world therefore they are subjective and participants

\subsubsection{Criticisms of Anti-Positivism}

Anti-positivism research has been criticised for "abandoning the scientific verification and in giving up hope of discovering useful generalisations about behaviour" (Mead cited in Cohen et al, 2000:27). Other criticisms concern the possibility of flawed controlled interviews or the (mis)interpretative methodology of verbal accounts to get at the meaning of events, rules and intentions. Such flaws can result in subject reports being incomplete or misleading. Bernstein (cited in Cohen et al, 2000) highlights the powerful position researchers can play which could easily, and adversely, influence the results of the research.

Furthermore, interpretive approaches run the risk of becoming "hermetically sealed from the world outside the participants' theatre of activity - they put artificial boundaries around subjects behaviour" (Cohen et al, 2000:27). Therefore, anti-positivism can be criticised for having a narrow microsociological stance, just as the positivists' philosophy can be criticised for their macro-sociological orientation (Cohen et al, 2000). 


\subsection{Mixed Method Approach}

However, not all theorists and researchers have shared in such paradigm divisions. In recent years the division between the two research paradigms discussed in the above section has narrowed. Researchers have found that both paradigms can be used effectively to solve methodological problems. The merging of the two approaches has led to what is known as a 'mixed method approach' (Creswell, 2003). Two groups, the 'critical theorists' and the 'pragmatists' have found the mixed methodology useful in their research.

\subsubsection{The Critical Theorists - Advocacy/Participatory Knowledge claims}

Mixed research methodology arose through the 1980s and 1990s from theorists who, according to Creswell (2003:9) thought that the:

Postpositivist assumptions imposed structural laws and theories that did not fit marginalised individuals or groups or did not adequately address issues of social justice.

Historically, some of the advocacy/participatory/emancipatory writers have drawn on the works of Marx, Freire and Habermas. More recently, critical theorists, which includes feminist theorists, critical race theorists, queer theorists and cultural theorists, have drawn on the works of Fay, Heron and Reason, and, Kemmis and Wilkinson (Creswell, 2003).

Such researchers believe that inquiry needs to be intertwined with politics and political agenda and, as Creswell (2003:9-10) notes:

Should contain an action agenda for reform that may change lives of the participants, the institution in which individuals work or live, and the researcher's life.

The role of the researcher is to act as a 'voice' for reform and change. Therefore, critical theorists are concerned with empowering human beings to transcend the constraints of race, class or gender (Creswell, 2003). 
Habermas, for example, recognises the need for both interpretive and empirical-analytical approaches (Seidman, 1989). Habermas argues that his emancipatory theory, based on reconstructionist theories of Chomsky, Kohlberg and Piaget (Seidman, 1989), requires both methods to bridge the gap between the instrumental logic and the 'life-world' values of knowledge, morality and art (Seidman, 1989). Furthermore, Habermas argues that communicative action theory, based on emanicipatory understanding, is “neither causal nor purely interpretive in outcome” (Keats, 1981:6).

Habermas also recognises the need for such a bridge to develop his theories of communicative actions. By successfully bridging the division between the paradigms, Habermas has demonstrated that mixed research methods can lead to authentic transformation in understanding how public opinion is reported and reflected, for example, as in newspapers.

\subsubsection{The Pragmatist Knowledge claims}

Another position concerning the claims on knowledge comes from the pragmatist group. There are many forms of pragmatism that arise out of actions, situations and consequences rather than focusing on causes (Creswell, 2003). According to Cherryholmes, Murphy and Creswell (2003), pragmatists, however, share several assumptions that can be summarised as follows:

- Pragmatists are not committed to any one system of philosophy and reality.

- Individual researchers have the freedom of choice to choose the methods, techniques and procedures best suited to their needs and purposes.

- Truth is what works at the time. Therefore, mixed method research can use both quantitative and qualitative data because they work to provide the best understanding of the research problem.

- Pragmatist researchers look at the 'what' and 'how' of research based on its intended purpose and consequences.

- Pragmatists agree that research occurs within social, historical, political and other contextual environments. 
- Some pragmatists for example, Cherryholmes, believe that "we need to stop asking questions about reality and the laws of nature” (Creswell, 2003:13).

- Therefore, mixed method research offers more flexible, adaptable and pragmatic approaches both in philosophical terms and in the practical application of research.

\subsection{The use of Mixed Method Research Approach for this thesis}

As mentioned in the previous section mixed method research has the advantage of giving 'freedom of choice' for the researcher. This enables the researcher to select the best and most suitable methods, techniques and procedures to meet the needs and purpose of the research. From a pragmatic point of view, mixed method research can look to many approaches for collecting and analysing data, which are highly relevant to the research under examination.

In order to answer the two questions posed in this thesis a survey sheet was developed (discussed later in this chapter). Specifically, the survey sheet needed to have two measurements. The first measurement needed to identify and to categorise the story and substory contents of each article found. This would provide the qualitative measure.

However, to merely identify the story and substory contents was insufficient because it would not provide any indication of the prominence of the story in respect of its length, position in the paper, use of photographs, and so on. Therefore a second measurement was needed. This measurement was embedded in the survey sheet and gave an 'attention score', or prominence index, known as the Budd score (explained later in this chapter). Using the Budd score, each article could be quantified in terms of newsworthy importance in relation to where the article was placed on the page as well as on what page it was placed. 
The mixed method research paradigm provided a practical way of collecting data. By using a 'one collection' phase both the qualitative and quantitative data could be collected simultaneously. Furthermore, the mixed method approach gave the freedom, flexibility and adaptability to use an open ended survey sheet in which more story subcontents could be added to record the frequently changing newspaper topics about education during the 12-year period surveyed.

\subsection{Phases of the Research}

As noted in the previous section the rationale for choosing a mixed method research approach was for the flexibility and adaptability that would lead to a broader and more accurate perspective on the results. This section discusses the phases of the research under the following headings:

- Selection of newspapers

- Sampling of dates

- $\quad$ The Budd score

- The survey sheet

\subsubsection{Selection of Newspapers}

The selection of five major New Zealand daily newspapers was influenced by several important considerations. First, the newspapers needed to cover New Zealand localities such that representation included the North and South Islands, the cities, towns and provinces, and all types of educational institutions. An equal distribution between morning and evening newspapers would have given another independent variable but The Evening Post, from Wellington, was the only surviving city evening newspaper during the period under study.

Second, a number of newspapers have ceased to be published and of those that have survived not all copies are available. The issues have either been lost or have deteriorated. As a consequence the choice was restricted to those papers listed below:

1. The New Zealand Herald: an Auckland city morning newspaper owned 
by Wilson Horton with a circulation of 213,150 (these figures and those below for 1999 were supplied by the New Zealand Press Association, 2002).

2. The Evening Post: a Wellington city evening newspaper owned by Independent Newspapers Limited (INL) with a circulation of 60,415.

3. The Press: a Christchurch morning newspaper owned by INL with a circulation of 95,506.

4. The Otago Daily Times: a Dunedin city morning newspaper the only independently New Zealand newspaper owned by the Allied Press with a circulation of 45,189.

5. The Southland Times: an Invercargill regional evening newspaper owned by INL with a circulation of 31,652.

Collectively, the circulation figures given in 1999 for the above newspapers was 445,912 and provided a comprehensive geographical spread across New Zealand. Furthermore, the selection had also been influenced by the newspapers' publishing survival and can be said to have complemented the 'reading public' majority. All newspapers were located and read, on microfilm, at The Alexander Turnbull Library.

\subsubsection{Sampling of Dates}

From the calender years 1988-1999 a selection of dates was chosen by taking a newspaper from every $11^{\text {th }}$ day but omitting Sunday. For example, in January 1988 the dates chosen were Friday $1^{\text {st }}$, Thursday $14^{\text {th }}$ and Wednesday $27^{\text {th }}$. Where no publication or educational items were found on the selected date a newspaper was chosen from either side of that date until educational items were found. Because there was no publication on New Year's Day 1988, Saturday $2^{\text {nd }}$ January 1988 was surveyed.

Every educational news article was recorded on a separate survey sheet (see 5.5.4) and given a Budd score (see 5.5.3). Educational articles excluded were those found in the classified advertisement section and the sports' section. However, when an article on sport appeared in the main body of the paper and included a reference to education or an educational institution then the article 
was included in the survey. For example, a school sports team winning an overseas competition in sport or a new subject in sport being introduced to a school would be included.

In all approximately 28 newspapers per year for each of the five newspapers were surveyed giving a total of 140 for each year. The total sample over the 12 year period was 1680 newspapers.

\subsubsection{The Budd Score}

As noted in chapter four the role of newspapers is not only to inform but also to remain viable and profitable. To do this the newspapers need to have public support. This is achieved by writing to a 'reader audience' that represents the public reading majority in their publications.

The question then raised is "What criteria do editors use to give one article prominence over another; that is, how is content analysis classified and do editors use the same classification criteria?”

Budd (1964), after analysing the treatment of United States news in four Australian and four New Zealand newspapers, found that editors generally used similar classification criteria. Therefore Budd (1964) was able to devise a 0-5 attention score based on the criteria summarised below:

1. One point was assigned to any article with a headline two columns or more in width, except that an article carrying a headline that occupied horizontally more than half the number of columns of the page was assigned two points.

2. One point was assigned to any story appearing above the fold or above the measured centre of any page. To be considered above the fold, the first line of the body of the text of the story had to appear above the fold.

3. One point was assigned to any article occupying three-fourths of a column or more (based on the column length of the newspaper concerned). For purposes of assigning the attention score, pictures accompanying articles were measured as part of the overall length 
of the story.

4. One point was assigned for any article appearing on page one, the editorial page or the sports page.

This thesis omitted the sports page unless the article was found in any of the other sections of the newspaper. Coloured photos were treated as monochromatic photos and scored accordingly. However, this thesis gave one point to the cable page as all five newspapers surveyed had such a page and it contained many overseas issues. Educational articles with a zero score were omitted.

\subsubsection{The Survey Sheet}

Each educational news article that was found was recorded on a survey sheet. The survey sheet (see Appendices A.5.1-A.5.6) was divided into six pages. The first page was subdivided into seven questions. Questions one and two were designed to give basic details about the newspaper, for example, the newspaper name, the date, the year and whether or not it was a North or South Island newspaper.

Question three gave the news location and was divided into three possibilities, local, national or international localities.

The fourth question related to newstype, which had nine subcategories to identify news article responsibility. They were editorial, feature, expert comment, and main page news (MPN), news, letter, photo, cartoon and student/pupil contribution. It was possible to have more than one position in this subcategory, which gave more specificity. For example, a letter to the editor could contain a photo and have been submitted by a student.

In conjunction with question three, it was also possible to specify the article's location. For example, it was possible for a letter to the editor that contained a photo to have been written by a student from a national region. 
The article was then calculated using the Budd scoring system (question five), while the sixth question identified the headline, which served as a useful guide for classifying the article content. The seventh question recorded whether or not a photocopy had been taken of the article.

During the preliminary stages of the study when validity and reliability were being explored, this research found that story content, irrespective of geographical locality or time frame, could be put into one or more of the twelve story contents, which were as follows:

1. Administration - covered articles concerning persons or groups administering educational matter for example, Ministers of Education, Members of Parliament, and Post-Primary Teachers’ Association.

2. Institution - covered items referring to any educational body for example, State, private or integrated institutions.

3. Institution Buildings - referred to educational buildings that were opened, closed, removed, vandalised, overcrowded or where safety was of concern.

4. Staff - covered staffing, both teaching and non-teaching, of educational institutions.

5. Students/pupils - covered articles about students being taught in a recognised educational institution.

6. Commercial Enterprise - referred to educational institution and/or students being funded by the business community.

7. Finance - covered articles reporting specifically on monetary matters.

8. Curriculum - covered articles reporting on issues relating to the curriculum taught or not taught in educational institutions.

9. General - covered articles reporting on issues relating to guest visitors, parents, ceremonial or historical events, de/zoning, enrolment schemes.

10. Maori Education - referred to articles reporting specifically on Maori issues including, Maori schools, Maori achievement and the Treaty of Waitangi.

11. Education Purpose - referred to articles about the reasons for education, for example, vocational, academic, compulsory, free, secular.

12. New Language - covered new words associated with new public management ('new right') policies, for example, provider/capture, 
commodity, Chief Executive Officer (CEO), State Owned Enterprise (SOE), knowledge economy.

Where articles could be classified under more than one story content, the decision to use one in preference to the other was based on how well the article contents would fit into the subcontent sheets. For example, when student fees were to be increased, the article could have been classified either under the 'administration' or 'students' story content category. The latter was chosen because the students protested about the fee increase. Had the article been classified under administration then the students' responses could have been lost.

The subcontent sheets, pages two to six, allowed for greater specificity. The substory contents lists are substantial and the details can be seen in the Appendices A.5.2-A.5.6. It should be noted that the story subcontent classifications could be crossed with any of the story content classifications and within any of the subcontent classification columns.

\subsection{Validity}

As mentioned in the above section the newspaper articles were coded and scored using the Budd score methodology. The question arises as to whether such a scoring method meets the criterion of "fitness for purpose" (Hall, 2003a: 2). That is, is such a scoring method relevant and useful for its intended purpose?

A number of studies in New Zealand newspapers have used indices, which measure the prominence or 'display' of news items. Such indices are useful in measuring how gatekeepers exercise their discretion in treating each news article (Cleveland, 1971). However, Budd found that the treatment of United States news in four Australian and four new Zealand newspapers was "inadequate for determining what differences there were in the way the various newspapers of his sample treated the content” (Cleveland, 1971:87). Budd (see 5.5.3) devised a method to allow for greater sensitivity to scoring, not only 
prominence of articles within a particular newspaper but also, between newspapers regardless of their variation in presentations and sizes.

Cleveland (1971) used the Budd score method to demonstrate the general functions of the New Zealand news media system along with the structure, the organisation and control of the daily press, broadcasting and television services in New Zealand.

Cleveland (1971) was able to sample the content of the three media services using the Budd score and from his analysis found, among other results, that education articles were given a low-medium level of prominence and that they were unsensational in nature.

Harbridge (1983) analysed three major daily newspapers in New Zealand in the treatment of industrial relations. In order to find out if industrial relations items were treated differently from other types of news items, Harbridge, following Cleveland's methodology (1971), took every eleventh newspaper from each of the three newspapers over a period of three months in the first quarter of 1982. From this Harbridge recorded the name of the paper, date, type of item, headline length and depth, article length and width, article prominence (Budd score) and the number of words appearing in the headline but not in the text.

Harbridge (1983) used the Budd's scoring when measuring the industrial relations articles to establish if the items were of more or less prominence to other non-industrial items. Harbridge's analysis found that there were variations between the three newspapers surveyed. The Evening Post placed greater importance on industrial relations than the other two newspapers surveyed (The New Zealand Herald and The Star). Furthermore, Harbridge was able to show not only the variations in story content between newspapers but also "the low levels of attention given to 'wage-tax trade off' talks and proposals" (Harbridge, 1983:15). Significantly, Harbridge found that the different treatment of industrial relations items, when compared to the non- 
industrial relations items, suggested "trivialisation and sensationalisation" (Harbridge, 1983:20) in newspaper reporting on such issues.

Roulston (1986) used a similar methodology to those of Cleveland (1971) and Harbridge (1983) to survey educational trends as reported in five major daily newspapers from 1901-1905 and from 1978-1982. In this study a significant mismatch was found in the earlier period between issues identified by historians and those reported in the earlier papers. In the later period, the issues as reported by the newspapers were closer to academic writing but overall educational articles were found to be given a low-medium Budd score. In keeping with Cleveland (1971), Roulston (1986) found that educational articles were largely unsensational as reflected by the lower range Budd scores.

The point to be made from this short review is that the Budd attention score has been found to be a robust method in categorising prominence of newspaper articles in a range of subject contents. All of the above studies indicated satisfaction with the validity of the approach.

\subsection{Reliability}

The above section focused on 'fitness for purpose', that is, validity. This section discusses the accuracy of the measurement - reliability. As Hall (2003a: 3) notes, "it is theoretically possible for a test to be reliable but not valid: it may make accurate measurements but be measuring the wrong thing!” This section will address the reliability of the data collection for this thesis under two sections:

- Pilot study

- Coding recheck

\subsubsection{Pilot Study}

Three newspapers from each of the five major daily New Zealand newspapers were randomly selected for each of the 12 years. This gave a total of 180 newspapers surveyed. From the 180 newspapers twelve main story contents were found across all newspapers, and within each of the story contents categories, the story subcontents were then added. As noted earlier each story 
subcontent column was left open-ended to add further subcontent topics when required.

In keeping with the questions on the survey sheet each story subcontent was given a numerical number that was later entered into a database for statistical and descriptive analysis using the SPSS programme.

\subsubsection{Coding Recheck}

To ensure the accuracy of the double coding method a random recheck of 30 newspapers was made some months after the data collection had finished. Because the double coding method required extensive training, particularly in the use of the sophisticated Budd score methodology, it became clear that it would be impractical to train someone. Therefore, a random selection of 30 newspapers was resurveyed using the blind recheck method.

Of the 30 newspaper articles, the coding for four articles could have been altered. The Otago Daily Times (24 August, 1995) could have been refined further to have included all tertiary staff rather than polytechnic and college of education staffs. The article however was predominantly concerned with the pay inequity of these two teaching staffs and therefore the addition did not influence the overall context of the story.

The second article, an editorial, was also from The Otago Daily Times (10 January, 1991). This article could have been rescored to a Budd score of three rather than four. In this case, the end of the article just reached the criterion for being more than three-quarters in length of the column. In other words, the article was at the borderline of Budd score three and four.

A third article came from The Southland Times (27 April, 1990). Although the problem occurred infrequently, the article raised the difficulty of how to give a Budd score when only a paragraph or a few sentences referred to education within a much larger and mainly unrelated context. In this case the article referred to education as an example in a wider political context. Initially the article treated as a whole by applying a Budd score of four. However, the 
problem was resolved because it was not relevant to those themes found either in the academic or professional literature and therefore was not used.

The last article, published in The Evening Post (10 May, 1988), concerned whether or not a special report about the Hawke Report (which covered several articles) should be given a Budd score of four, or if each article should have been treated separately and scored accordingly. Because the special report had a headline that spanned the full width of the article and was encompassed in a box it was decided to treat the report as a whole. Regardless of the scoring, the story content and subcontent remained unchanged in terms of coding. In the case of this report the decision was made to retain the original coding.

The above four problems, even where subsequent alterations were made, did not influence the results and subsequent discussion in relation to the questions this thesis posed.

Further rechecking also occurred when entering the data into the SPSS programme. The data were rechecked as computer entries were made and again later when the entries themselves were corrected for input errors. A final recheck occurred during the discussion of Budd score four and five articles these articles were selected for special consideration because of their high scores and were therefore rechecked in respect of their Budd categories.

\subsection{Ethical Considerations}

This thesis did not require consent from the Ethics Committee because it did not involve surveying human subjects.

\subsection{Summary}

This chapter began with a historical overview of the deep divisions that existed between 'Positivists' and 'Anti-positivists' in their two opposing philosophical approaches to the concept of reality. Not surprisingly each paradigm was criticised for its stance on social reality. The anti-positivists were criticised for having a narrow micro-sociological stance, while the positivists' philosophy was criticised for their macro-sociological orientation (Cohen et al, 2000). 
More recently critical and pragmatic theorists, have recognised the need for both paradigms because mixed method research gives 'freedom of choice' to use the methods, techniques and procedures best suited to the needs and purposes of their research. As a result such methods offer a more flexible, adaptable and pragmatic approach both in philosophical terms and in practical application.

This thesis is based upon mixed method research because it was a necessary choice to collect both qualitative and quantitative data simultaneously in order to address the main research question.

The phases of research for this thesis used similar methods to those of Cleveland (1971), Harbridge (1983) and Roulston (1986) in the selection of five major daily newspapers, the sampling of dates and in the development of a survey sheet, which had a double coding method. By using a double coding method each article's story content and subcontent was identified and given a prominence index, that is a Budd score. Budd (1964), Cleveland (1971), Harbridge (1983) and Roulston (1986) have supported this approach in respect of its validity for assessing prominence of newspaper articles. Reliability was established by using a pilot study and a recoding of a sample of 30 articles. 


\section{CHAPTER SIX - RESULTS AND ANALYSES FROM THE FIVE MAJOR DAILY NEWSPAPERS SURVEYED}

\subsection{Introduction}

This chapter presents the statistical results and analyses of the findings from the five major New Zealand daily newspapers surveyed during the 1988-1999 period. Because of the large volume of results, this chapter has been divided into the following sections:

- Comparative analysis of newspapers

- Comparative analysis of story content

Under the first of these, the five newspapers are compared in respect of the emphasis they gave to locality of story (local, national, international), the newstype of the section of the paper (editorial, main page news, feature article, etc.) and Budd score (the prominence of each article).

Under the second heading, analyses are provided of the story content of articles with a breakdown by:

- Newspaper and story content

- Newstype and Budd score

- Story content and Budd score

Towards the end of the chapter, the results are drawn together in an overall summary. It should be noted that this chapter is largely descriptive in nature it simply presents data through the 'counts' that emerged from the survey. The next chapter provides a more qualitative analysis by examining the articles which received Budd scores of four and five. These give an indication of the kinds of issues that were considered to be of significance by the newspapers.

\subsection{Newspaper by Locality}

\subsubsection{Overview of newspaper by Locality}

The total number of articles surveyed from all the five papers for the 19881999 period was 6166 (Table 6.2.1). The Otago Daily Times had the most articles published, a total of 1538, followed by The Press (1402). The two 
North Island papers, The New Zealand Herald and The Evening Post had the least with 971 and 1033 respectively.

Table 6.2.1 Summary of all Newspapers giving their Locality distribution: 1988-1999.

\begin{tabular}{|c|c|c|c|c|c|c|}
\hline Locality & $\begin{array}{l}\text { New } \\
\text { Zealand } \\
\text { Herald }\end{array}$ & $\begin{array}{l}\text { Evening } \\
\text { Post }\end{array}$ & Press & $\begin{array}{l}\text { Otago } \\
\text { Daily } \\
\text { Times }\end{array}$ & $\begin{array}{l}\text { Southland } \\
\text { Times }\end{array}$ & Total \\
\hline $\begin{array}{l}\text { Local Count } \\
\text { \% within Locality } \\
\text { \% within Newspaper } \\
\text { \% of Total }\end{array}$ & $\begin{array}{l}612 \\
13.5 \% \\
63.0 \% \\
9.9 \%\end{array}$ & $\begin{array}{l}901 \\
19.9 \% \\
87.2 \% \\
14.6 \%\end{array}$ & $\begin{array}{l}964 \\
21.2 \% \\
68.8 \% \\
15.6 \%\end{array}$ & $\begin{array}{l}1148 \\
25.3 \% \\
74.6 \% \\
18.6 \%\end{array}$ & $\begin{array}{l}914 \\
20.1 \% \\
74.8 \% \\
14.8 \%\end{array}$ & $\begin{array}{l}4539 \\
100.0 \% \\
73.6 \% \\
73.6 \%\end{array}$ \\
\hline $\begin{array}{l}\text { National Count } \\
\text { \% within Locality } \\
\text { \% within Newspaper } \\
\text { \% of Total }\end{array}$ & $\begin{array}{l}298 \\
21.3 \% \\
30.7 \% \\
4.8 \%\end{array}$ & $\begin{array}{l}93 \\
6.6 \% \\
9.0 \% \\
1.5 \%\end{array}$ & $\begin{array}{l}385 \\
27.5 \% \\
27.5 \% \\
6.2 \%\end{array}$ & $\begin{array}{l}354 \\
25.3 \% \\
23.0 \% \\
5.7 \%\end{array}$ & $\begin{array}{l}270 \\
19.3 \% \\
22.1 \% \\
4.4 \%\end{array}$ & $\begin{array}{l}1400 \\
100.0 \% \\
22.7 \% \\
22.7 \%\end{array}$ \\
\hline $\begin{array}{l}\text { International Count } \\
\% \text { within Locality } \\
\% \text { within Newspaper } \\
\% \text { of Total }\end{array}$ & $\begin{array}{l}61 \\
26.9 \% \\
6.3 \% \\
1.0 \%\end{array}$ & $\begin{array}{l}39 \\
17.2 \% \\
3.8 \% \\
.6 \%\end{array}$ & $\begin{array}{l}53 \\
23.3 \% \\
3.8 \% \\
.9 \%\end{array}$ & $\begin{array}{l}36 \\
15.9 \% \\
2.3 \% \\
.6 \%\end{array}$ & $\begin{array}{l}38 \\
16.7 \% \\
3.1 \% \\
.6 \%\end{array}$ & $\begin{array}{l}227 \\
100.0 \% \\
3.7 \% \\
3.7 \%\end{array}$ \\
\hline $\begin{array}{l}\text { Total Count } \\
\text { \% within Locality } \\
\text { \% within Newspaper } \\
\text { \% of Total }\end{array}$ & $\begin{array}{l}971 \\
15.7 \% \\
100.0 \% \\
15.7 \%\end{array}$ & $\begin{array}{l}1033 \\
16.8 \% \\
100.0 \% \\
16.8 \%\end{array}$ & $\begin{array}{l}1402 \\
22.7 \% \\
100.0 \% \\
22.7 \%\end{array}$ & $\begin{array}{l}1538 \\
24.9 \% \\
100.0 \% \\
24.9 \%\end{array}$ & $\begin{array}{l}1222 \\
19.8 \% \\
100.0 \% \\
19.8 \%\end{array}$ & $\begin{array}{l}6166 \\
100.0 \% \\
100.0 \% \\
100.0 \%\end{array}$ \\
\hline
\end{tabular}

\section{Local content}

Local content was the most frequently published locality with a total of 4539 articles. This represented $73.6 \%$ of the total count of all localities. The Otago Daily Times had the most local content with 1148 articles; however, proportionately The Evening Post had the highest percentage (87.2\%). The New Zealand Herald had the least number of local articles, which was also the lowest proportionately (63.0\%) with 612. The other three papers had similar publication numbers and percentages.

\section{National content}

The total number of national content articles published during this time was 1400. This accounted for $22.7 \%$ of the total count of localities. The most number of national articles was provided by The Press (385) but proportionately The New Zealand Herald (30.7\% of articles) provided the greatest percentage. Clearly, The Evening Post provided the least number of articles (93) and the lowest percentage (9.0\%). 


\section{International content}

The international locality was the least published. In all 227 articles were surveyed over the 12 year period. This figure represented $3.7 \%$ of the total locality count. The New Zealand Herald published the most international articles with a total of 61 publications. Next came The Press having published 53 articles, while The Evening Post, The Southland Times and The Otago Daily Times had 39, 38 and 36 respectively.

\section{Summary of Locality}

Overall, it is clear that the South Island papers provided more education related articles than the two North Island papers. In relation to locality, all newspapers focused on more local than either national or international content. The Evening Post provided greatest emphasis on local news (87.2\% of its total content being in this locality), whereas The New Zealand Herald gave greatest emphasis to national and international content.

\subsubsection{Newspapers by Newstype.}

The results of the newstype categories are summarised in Table 6.2.2. Please note that percentages do not necessarily add up to $100 \%$ because an article can have more than one newstype. The three most frequently occurring newstype categories, in descending order, were 'news' with 4293 publications, 'photos' with 1813 and 'main page news' with 707 articles.

\section{News}

News items represented almost 70\% of the total newspaper count, while photos and main page news represented $29.4 \%$ and $11.5 \%$ respectively. Within the news category there was considerable variation in the number of articles published. The Otago Daily Times published 1099 news articles during this period. The Press was found to have published 131 fewer than The Otago Daily Times with 968 news articles and The Southland Times published 904 news articles. However, The three South Island papers contributed $69.2 \%$ of all news articles, while the two North Island papers had a combined contribution of 30.8\% of News articles. The Evening Post had 710 News articles published, while The New Zealand Herald published 612 during the 1988-1999 period. 
Table 6.2.2 Summary of all Newspapers giving Newstype: 1988-1999.

\begin{tabular}{|c|c|c|c|c|c|c|}
\hline Newstype & $\begin{array}{l}\text { New } \\
\text { Zealand } \\
\text { Herald } \\
\end{array}$ & $\begin{array}{l}\text { Evening } \\
\text { Post }\end{array}$ & Press & $\begin{array}{l}\text { Otago } \\
\text { Daily } \\
\text { Times } \\
\end{array}$ & $\begin{array}{l}\text { Southland } \\
\text { Times }\end{array}$ & Total \\
\hline $\begin{array}{l}\text { Editorial Count } \\
\% \text { within Editorial } \\
\% \text { within Newspaper } \\
\% \text { of Total }\end{array}$ & $\begin{array}{l}41 \\
28.3 \% \\
4.2 \% \\
.7 \%\end{array}$ & $\begin{array}{l}22 \\
15.2 \% \\
2.1 \% \\
.4 \%\end{array}$ & $\begin{array}{l}21 \\
14.5 \% \\
1.5 \% \\
.3 \%\end{array}$ & $\begin{array}{l}35 \\
24.1 \% \\
2.3 \% \\
.6 \%\end{array}$ & $\begin{array}{l}26 \\
17.9 \% \\
2.1 \% \\
.4 \%\end{array}$ & $\begin{array}{l}145 \\
100.0 \% \\
2.4 \% \\
2.4 \%\end{array}$ \\
\hline $\begin{array}{l}\text { Features Count } \\
\% \text { within Features } \\
\% \text { within Newspaper } \\
\% \text { of Total }\end{array}$ & $\begin{array}{l}35 \\
11.4 \% \\
3.6 \% \\
.6 \%\end{array}$ & $\begin{array}{l}73 \\
23.8 \% \\
7.1 \% \\
1.2 \%\end{array}$ & $\begin{array}{l}79 \\
25.7 \% \\
5.6 \% \\
1.3 \%\end{array}$ & $\begin{array}{l}58 \\
18.9 \% \\
3.8 \% \\
.9 \%\end{array}$ & $\begin{array}{l}62 \\
20.2 \% \\
5.1 \% \\
1.0 \%\end{array}$ & $\begin{array}{l}307 \\
100.0 \% \\
5.0 \% \\
5.0 \%\end{array}$ \\
\hline $\begin{array}{l}\text { Main Page News } \\
\text { Count } \\
\text { \% within MPN } \\
\text { \% within Newspaper } \\
\text { \% of Total }\end{array}$ & $\begin{array}{l}100 \\
14.1 \% \\
10.3 \% \\
1.6 \%\end{array}$ & $\begin{array}{l}104 \\
14.7 \% \\
10.1 \% \\
1.7 \%\end{array}$ & $\begin{array}{l}137 \\
19.4 \% \\
9.8 \% \\
2.2 \%\end{array}$ & $\begin{array}{l}187 \\
26.4 \% \\
12.2 \% \\
3.0 \%\end{array}$ & $\begin{array}{l}179 \\
\\
25.3 \% \\
14.6 \% \\
2.9 \%\end{array}$ & $\begin{array}{l}707 \\
100.0 \% \\
11.5 \% \\
11.5 \%\end{array}$ \\
\hline $\begin{array}{l}\text { News Count } \\
\text { \% within news } \\
\% \text { within Newspaper } \\
\% \text { of Total }\end{array}$ & $\begin{array}{l}612 \\
14.3 \% \\
63.0 \% \\
9.9 \%\end{array}$ & $\begin{array}{l}710 \\
16.5 \% \\
68.7 \% \\
11.5 \%\end{array}$ & $\begin{array}{l}968 \\
22.5 \% \\
69.0 \% \\
15.7 \%\end{array}$ & $\begin{array}{l}1099 \\
25.6 \% \\
71.5 \% \\
17.8 \%\end{array}$ & $\begin{array}{l}904 \\
21.1 \% \\
74.0 \% \\
14.7 \%\end{array}$ & $\begin{array}{l}4293 \\
100.0 \% \\
69.6 \% \\
69.6 \%\end{array}$ \\
\hline $\begin{array}{l}\text { Letter Count } \\
\text { \% within letters } \\
\% \text { within Newspaper } \\
\% \text { of Total }\end{array}$ & $\begin{array}{l}157 \\
23.05 \\
16.2 \% \\
2.5 \%\end{array}$ & $\begin{array}{l}109 \\
15.9 \% \\
10.6 \% \\
1.8 \%\end{array}$ & $\begin{array}{l}190 \\
27.8 \% \\
13.6 \% \\
3.1 \%\end{array}$ & $\begin{array}{l}147 \\
21.5 \% \\
9.6 \% \\
2.4 \%\end{array}$ & $\begin{array}{l}81 \\
11.8 \% \\
6.6 \% \\
1.3 \%\end{array}$ & $\begin{array}{l}684 \\
100.0 \% \\
11.1 \% \\
11.1 \%\end{array}$ \\
\hline $\begin{array}{l}\text { Expert Com. Count } \\
\% \text { within Expert Com. } \\
\text { \% within Newspaper } \\
\% \text { of Total }\end{array}$ & $\begin{array}{l}41 \\
20.0 \% \\
4.2 \% \\
.7 \%\end{array}$ & $\begin{array}{l}31 \\
15.1 \% \\
3.0 \% \\
.5 \%\end{array}$ & $\begin{array}{l}44 \\
21.5 \% \\
3.1 \% \\
.7 \%\end{array}$ & $\begin{array}{l}47 \\
22.9 \% \\
3.1 \% \\
.8 \%\end{array}$ & $\begin{array}{l}42 \\
20.5 \% \\
3.4 \% \\
.7 \%\end{array}$ & $\begin{array}{l}205 \\
100.0 \% \\
3.3 \% \\
3.3 \%\end{array}$ \\
\hline $\begin{array}{l}\text { Photo Count } \\
\text { \% within Photo } \\
\text { \% within Newspaper } \\
\text { \% of Total }\end{array}$ & $\begin{array}{l}159 \\
8.8 \% \\
16.4 \% \\
2.6 \%\end{array}$ & $\begin{array}{l}295 \\
16.3 \% \\
28.6 \% \\
4.8 \%\end{array}$ & $\begin{array}{l}410 \\
22.6 \% \\
29.2 \% \\
6.6 \%\end{array}$ & $\begin{array}{l}517 \\
28.5 \% \\
33.6 \% \\
8.4 \%\end{array}$ & $\begin{array}{l}432 \\
23.8 \% \\
35.4 \% \\
7.0 \%\end{array}$ & $\begin{array}{l}1813 \\
100.0 \% \\
29.4 \% \\
29.4 \%\end{array}$ \\
\hline $\begin{array}{l}\text { Cartoon Count } \\
\text { \% within Cartoon } \\
\% \text { within Newspaper } \\
\% \text { of Total }\end{array}$ & $\begin{array}{l}1 \\
7.7 \% \\
.1 \% \\
.0 \%\end{array}$ & $\begin{array}{l}3 \\
23.1 \% \\
.3 \% \\
.0 \%\end{array}$ & $\begin{array}{l}2 \\
15.4 \% \\
.1 \% \\
.0 \%\end{array}$ & $\begin{array}{l}7 \\
53.8 \% \\
.5 \% \\
.1 \%\end{array}$ & & $\begin{array}{l}13 \\
100.0 \% \\
.2 \% \\
.2 \%\end{array}$ \\
\hline $\begin{array}{l}\text { Pupil Contribution } \\
\% \text { within Pupil Contr. } \\
\% \text { within Newspaper } \\
\% \text { of Total }\end{array}$ & $\begin{array}{l}1 \\
2.2 \% \\
.1 \% \\
.0 \%\end{array}$ & $\begin{array}{l}6 \\
13.3 \% \\
.6 \% \\
.1 \%\end{array}$ & $\begin{array}{l}9 \\
20.0 \% \\
.6 \% \\
.1 \%\end{array}$ & $\begin{array}{l}17 \\
37.8 \% \\
1.1 \% \\
.3 \%\end{array}$ & $\begin{array}{l}12 \\
26.7 \% \\
1.0 \% \\
.2 \%\end{array}$ & $\begin{array}{l}45 \\
100.0 \% \\
.7 \% \\
.7 \%\end{array}$ \\
\hline $\begin{array}{l}\text { Total Count } \\
\% \text { within Newspaper } \\
\% \text { of Total }\end{array}$ & $\begin{array}{l}971 \\
100.0 \% \\
15.7 \%\end{array}$ & $\begin{array}{l}1033 \\
100.0 \% \\
16.8 \%\end{array}$ & $\begin{array}{l}1402 \\
100.0 \% \\
22.7 \%\end{array}$ & $\begin{array}{l}1538 \\
100.0 \% \\
24.9 \%\end{array}$ & $\begin{array}{l}1222 \\
100.0 \% \\
19.8 \%\end{array}$ & $\begin{array}{l}6166 \\
100.0 \% \\
100.0 \%\end{array}$ \\
\hline
\end{tabular}

\section{Photos}

Photos were the second most frequently used newstype. Photos were found, within the total newstype count, to contribute almost $30 \%$ of all newstype articles (Table 6.2.2). The Otago Daily Times, The Southland Times and The Press had 517, 432 and 410 photos respectively. Their combined photo 
contributions came close to $75 \%$ within the total photo count. The two North Island papers' combined photo contributions provided the remaining 25\% within the total photo count. The Evening Post's photo count was 295, while The New Zealand Herald published the least photos with a total of 159. There was a steady increase in the percentage of photos within newspapers as the newspapers trekked down New Zealand. The New Zealand Herald published the least (16.4\%) photos within its newspaper while The Southland Times the most (35.4\%). A further difference was found between the two North Island papers where The New Zealand Herald published almost half the number of photos within its newspaper (16.4\%) compared to The Evening Post (28.6\%).

\section{Main Page News}

The third most frequently occurring newstype category was found to be main page news with a total of 707 published articles. Main page news articles represented $11.5 \%$ of the total count within newspapers with all newspapers sharing a similar percentage within newspapers (Table 6.2.2). Compared with the news and photo publications, 69.6\% and 29.4\% respectively (Table 6.2.2), the figure for education articles appearing on main page news is considerably less. Articles appearing as main page news (discussed in chapter five) are considered to be important. They are designed to catch the reader's eye with what is considered to be significantly newsworthy and as a result attain higher Budd scores (discussed in chapters four and five) because of their prominence on the page. Therefore, the low percentage of education articles appearing as main page news suggests education is less newsworthy than other news items.

\section{Letters}

Letters to the editor from all newspapers totalled 684, representing $11.1 \%$ of all newstype count within all newspapers (Table 6.2.2). The Press published the most with 190 letters. The New Zealand Herald followed this with 157, closely followed by The Otago Daily Times with 147. The Evening Post published 109, while The Southland Times published the least with 81. However, the percentage within the newspapers varied markedly with The New Zealand Herald devoting $16.2 \%$ to this newstype while The Southland Times provided the least $(6.6 \%)$. 


\section{Features}

In this newstype category 307 'feature' articles were found. This represented $5.0 \%$ of the total count of all newstypes (6.2.2). The Press published the most features, 79 in all. The Evening Post published 73 while The Southland Times and The Otago Daily Times published 62 and 58 features respectively. The New Zealand Herald had the least feature articles published with 35.

\section{Miscellaneous}

The remaining newstypes have a combined total count of 408 articles. This represents $6.6 \%$ of the 6166 surveyed articles (Table 6.2.2). Expert comments had 205 articles. With the exception of The Evening Post, all other papers had 40 or more articles in this newstype. The Evening Post published 31 articles only (Table 6.2.2). There were 145 'editorials' with The New Zealand Herald publishing the most with 41. This was followed by The Otago Daily Times with 35 editorials. The remaining three papers had similar numbers of editorial publications in the 20-26 range. The 'pupil/student contribution' count was 45 in total (Table 6.2.2). The Otago Daily Times published 17 and The Southland Times with 12 thus making up $64.5 \%$ of the total of the pupil/student contributions. The Press and The Evening Post had nine and six respectively. The New Zealand Herald had the least with one in this category. In all 13 'cartoons' were published with the numbers varying from seven, in The Otago Daily Times, to one in The New Zealand Herald. No cartoons were found in The Southland Times.

\section{Summary of newspapers by Newstype.}

The South Island newspapers published more articles on education than the two North Island newspapers. In particular, the South Island newspapers published more articles on the most frequently published newstypes, news and photos. South Island papers also published more on pupil/student contributions. However, while The Press published more letters, The New Zealand Herald had the greatest percentage within newspapers. Little difference was found in the remaining newstype content other than The Southland Times, which had no cartoon publications. 


\subsubsection{Newspaper by Budd Score}

\section{Overview of newspapers by Budd Score}

In addition to quantifying the number of newspaper articles published during the 12-year period a further measurement was used - the Budd score (described in chapters four and five). The Budd score measures, on a 0-5 scale, the level of importance an article has in relation to other articles published within the same paper. Those with a low score are not considered to be as important as those with a higher Budd score of four or five. This study measured articles that were found within the 1-5 (not zero) Budd score range (Table 6.2.3).

Table 6.2.3 Summary of all Newspapers by Budd Score: 1988-1999.

\begin{tabular}{|c|c|c|c|c|c|c|}
\hline Budd Score & $\begin{array}{l}\text { New } \\
\text { Zealand } \\
\text { Herald } \\
\end{array}$ & $\begin{array}{l}\text { Evening } \\
\text { Post }\end{array}$ & Press & $\begin{array}{l}\text { Otago } \\
\text { Daily } \\
\text { Times }\end{array}$ & $\begin{array}{l}\text { Southland } \\
\text { Times }\end{array}$ & Total \\
\hline $\begin{array}{l}\text { 1 Count } \\
\text { \% within Budd Score } \\
\% \text { within Newspaper } \\
\% \text { of Total }\end{array}$ & $\begin{array}{l}333 \\
15.4 \% \\
34.3 \% \\
5.4 \%\end{array}$ & $\begin{array}{l}304 \\
14.1 \% \\
29.4 \% \\
4.9 \%\end{array}$ & $\begin{array}{l}616 \\
28.5 \% \\
43.9 \% \\
10.0 \%\end{array}$ & $\begin{array}{l}486 \\
22.5 \% \\
31.6 \% \\
7.9 \%\end{array}$ & $\begin{array}{l}421 \\
19.5 \% \\
34.5 \% \\
6.8 \%\end{array}$ & $\begin{array}{l}2160 \\
100.0 \% \\
35.0 \% \\
35.0 \%\end{array}$ \\
\hline $\begin{array}{l}2 \text { Count } \\
\text { \% within Budd Score } \\
\% \text { within Newspaper } \\
\% \text { of Total }\end{array}$ & $\begin{array}{l}380 \\
13.1 \% \\
39.1 \% \\
6.2 \%\end{array}$ & $\begin{array}{l}553 \\
19.0 \% \\
53.5 \% \\
9.0 \%\end{array}$ & $\begin{array}{l}604 \\
20.8 \% \\
43.1 \% \\
9.8 \%\end{array}$ & $\begin{array}{l}767 \\
26.4 \% \\
49.9 \% \\
12.4 \%\end{array}$ & $\begin{array}{l}602 \\
20.7 \% \\
49.3 \% \\
9.8 \%\end{array}$ & $\begin{array}{l}2906 \\
100.0 \% \\
47.1 \% \\
47.1 \%\end{array}$ \\
\hline $\begin{array}{l}3 \text { Count } \\
\text { \% within Budd Score } \\
\% \text { within Newspaper } \\
\% \text { of Total }\end{array}$ & $\begin{array}{l}196 \\
23.2 \% \\
20.2 \% \\
3.2 \%\end{array}$ & $\begin{array}{l}130 \\
15.4 \% \\
12.6 \% \\
2.1 \%\end{array}$ & $\begin{array}{l}137 \\
16.2 \% \\
9.8 \% \\
2.2 \%\end{array}$ & $\begin{array}{l}224 \\
26.5 \% \\
14.6 \% \\
3.6 \%\end{array}$ & $\begin{array}{l}157 \\
18.6 \% \\
12.8 \% \\
2.5 \%\end{array}$ & $\begin{array}{l}844 \\
100.0 \% \\
13.7 \% \\
13.7 \%\end{array}$ \\
\hline $\begin{array}{l}\text { 4 Count } \\
\text { \% within Budd Score } \\
\text { \% within Newspaper } \\
\% \text { of Total }\end{array}$ & $\begin{array}{l}58 \\
25.8 \% \\
6.0 \% \\
.9 \%\end{array}$ & $\begin{array}{l}40 \\
17.8 \% \\
3.9 \% \\
.6 \%\end{array}$ & $\begin{array}{l}38 \\
16.9 \% \\
2.7 \% \\
.6 \%\end{array}$ & $\begin{array}{l}53 \\
23.6 \% \\
3.4 \% \\
.9 \%\end{array}$ & $\begin{array}{l}36 \\
16.0 \% \\
2.9 \% \\
.6 \%\end{array}$ & $\begin{array}{l}225 \\
100.0 \% \\
3.6 \% \\
3.6 \%\end{array}$ \\
\hline $\begin{array}{l}\text { 5 Count } \\
\text { \% within Budd Score } \\
\text { \% within Newspaper } \\
\% \text { of Total }\end{array}$ & $\begin{array}{l}4 \\
12.9 \% \\
.4 \% \\
.1 \%\end{array}$ & $\begin{array}{l}6 \\
19.4 \% \\
.6 \% \\
.1 \%\end{array}$ & $\begin{array}{l}7 \\
22.6 \% \\
.5 \% \\
.1 \%\end{array}$ & $\begin{array}{l}8 \\
25.8 \% \\
.5 \% \\
.1 \%\end{array}$ & $\begin{array}{l}6 \\
19.4 \% \\
.5 \% \\
.1 \%\end{array}$ & $\begin{array}{l}31 \\
100.0 \% \\
.5 \% \\
.5 \%\end{array}$ \\
\hline $\begin{array}{l}\text { Total Count } \\
\text { \% within Budd Score } \\
\% \text { within Newspaper } \\
\% \text { of Total }\end{array}$ & $\begin{array}{l}971 \\
15.7 \% \\
100.0 \% \\
15.7 \%\end{array}$ & $\begin{array}{l}1033 \\
16.8 \% \\
100.0 \% \\
16.8 \%\end{array}$ & $\begin{array}{l}1402 \\
22.7 \% \\
100.0 \% \\
22.7 \%\end{array}$ & $\begin{array}{l}1538 \\
24.9 \% \\
100.0 \% \\
24.9 \%\end{array}$ & $\begin{array}{l}1222 \\
19.8 \% \\
100.0 \% \\
19.8 \%\end{array}$ & $\begin{array}{l}6166 \\
100.0 \% \\
100.0 \% \\
100.0 \%\end{array}$ \\
\hline
\end{tabular}




\section{Newspapers by Budd Scores of One and Two}

The Budd scores for all newspapers were mainly concentrated in lower Budd score levels of one and two (Table 6.2.3). Articles mainly with a Budd score of two (2906) predominated, giving $47.1 \%$ within the total newspaper counts. A further 2160 articles had a Budd score of one. This contributed to 35\% of all Budd scores. The combined total of articles with a Budd score of one or two counted for 5066 of the total count, providing over $80 \%$ of all the educational articles published from 1988-1999.

Within the Budd score of one The Press had the most publications with 616 articles. The other two South Island papers, The Otago Daily Times and The Southland Times, had 486 and 421 publications respectively. Both North Island papers had similar publication counts in the 300 range (Table 6.2.3).

The Otago Daily Times had the most articles, 767, with a Budd score of two. The Southland Times (602) and The Press (604) were virtually equal with their scores. The Evening Post published 553 articles with a Budd score of two, while The New Zealand Herald had the least with 380 articles. This was almost half of The Otago Daily Times number of articles. Although The Evening Post had the fourth least articles with a Budd score of two, the percentage within the newspapers count was 53.5\% and therefore The Evening Post published the most articles within this Budd score relative to their total frequency of articles.

\section{Newspapers by Budd Scores Three, Four and Five}

Those with a Budd score of three numbered 844 of all articles surveyed an equivalent of $13.7 \%$ of the total newspaper count. The New Zealand Herald provided the highest percentage (20\%) within its newspaper count. The total count for newspaper articles with a Budd score of four was 225 , or $3.6 \%$ of the total found within all newspapers, but The New Zealand Herald had twice as many articles at this level within its newspaper (6.0\%). The highest possible Budd score, that of five, was obtained for only 31 articles. The Otago Daily Times had eight articles, The Press published seven, and The Evening Post and The Southland Times each published six articles. The least number was 
published in The New Zealand Herald with only four articles. In all, the total percentage of articles with a Budd score of five was 0.5 per cent.

\section{Summary of newspapers by Budd Score}

Articles with either a Budd score of one or two provided $80 \%$ of all newspaper articles. A greater percentage of articles with a Budd score of one (70.5\%) were found in the South Island newspapers. Not surprisingly, the number of articles associated with Budd scores higher than two decreased from 13.7\% for three, to $3.6 \%$ and $0.5 \%$ for four and five respectively. Some variations were noted between papers.

\subsection{Story Content Analysis}

This section is concerned with the results from the newspapers surveyed that focus on story content. This will be divided into three subsections as follows:

- Newspaper and Story Content

- Newstype and Budd score

- Story content and Budd score

\subsubsection{Newspaper and Story Content}

\section{Overview of newspaper and Story Content}

The results of newspaper by story content are summarised in Table 6.3.1. The most frequent story content was the student category with a count of 2132 articles. This represented $34.6 \%$ of the story content of all newspapers. The second most frequently published story content category concerned institutions, with 1275 articles. This category was found to have $20 \%$ of all story contents within all newspapers. Compared with the student category, the institution publications were almost half those of the former. The third most frequently published story content category was administration with 864 articles, while the staff category closely followed fourth with 836 articles. 
Table 6.3.1 Summary of Newspaper by Story Content: 1988-1999.

\begin{tabular}{|c|c|c|c|c|c|c|}
\hline Story Content & $\begin{array}{l}\text { New } \\
\text { Zealand } \\
\text { Herald } \\
\end{array}$ & $\begin{array}{l}\text { Evening } \\
\text { Post }\end{array}$ & Press & $\begin{array}{l}\text { Otago } \\
\text { Daily } \\
\text { Times } \\
\end{array}$ & $\begin{array}{l}\text { Southland } \\
\text { Times }\end{array}$ & Total \\
\hline $\begin{array}{l}\text { Admin. Count } \\
\% \text { within Admin. } \\
\% \text { within Newspaper } \\
\% \text { of Total }\end{array}$ & $\begin{array}{l}141 \\
16.3 \% \\
14.5 \% \\
2.3 \%\end{array}$ & $\begin{array}{l}149 \\
17.2 \% \\
14.4 \% \\
2.4 \%\end{array}$ & $\begin{array}{l}190 \\
22.0 \% \\
13.6 \% \\
3.1 \%\end{array}$ & $\begin{array}{l}208 \\
24.1 \% \\
13.5 \% \\
3.4 \%\end{array}$ & $\begin{array}{l}176 \\
20.4 \% \\
14.4 \% \\
2.9 \%\end{array}$ & $\begin{array}{l}864 \\
100.0 \% \\
14.0 \% \\
14.0 \%\end{array}$ \\
\hline $\begin{array}{l}\text { Institution Count } \\
\% \text { within Institution } \\
\% \text { within Newspaper } \\
\% \text { of Total }\end{array}$ & $\begin{array}{l}144 \\
11.3 \% \\
14.8 \% \\
2.3 \%\end{array}$ & $\begin{array}{l}174 \\
13.6 \% \\
16.8 \% \\
2.8 \%\end{array}$ & $\begin{array}{l}310 \\
24.3 \% \\
22.1 \% \\
5.0 \%\end{array}$ & $\begin{array}{l}393 \\
30.8 \% \\
25.6 \% \\
6.4 \%\end{array}$ & $\begin{array}{l}254 \\
19.9 \% \\
20.8 \% \\
4.1 \%\end{array}$ & $\begin{array}{l}1275 \\
100.0 \% \\
20.7 \% \\
20.7 \%\end{array}$ \\
\hline $\begin{array}{l}\text { Instit. Build. Count } \\
\% \text { within Instit. Build. } \\
\% \text { within Newspaper } \\
\% \text { of Total }\end{array}$ & $\begin{array}{l}24 \\
25.3 \% \\
2.5 \% \\
.4 \%\end{array}$ & $\begin{array}{l}43 \\
45.3 \% \\
4.2 \% \\
.7 \%\end{array}$ & $\begin{array}{l}8 \\
8.4 \% \\
.6 \% \\
.1 \%\end{array}$ & $\begin{array}{l}2 \\
2.1 \% \\
.1 \% \\
.0 \%\end{array}$ & $\begin{array}{l}18 \\
18.9 \% \\
1.5 \% \\
.3 \%\end{array}$ & $\begin{array}{l}95 \\
100.0 \% \\
1.5 \% \\
1.5 \%\end{array}$ \\
\hline $\begin{array}{l}\text { Staff Count } \\
\% \text { within Staff } \\
\% \text { within Newspaper } \\
\% \text { of Total }\end{array}$ & $\begin{array}{l}158 \\
18.9 \% \\
16.3 \% \\
2.6 \%\end{array}$ & $\begin{array}{l}158 \\
18.9 \% \\
15.3 \% \\
2.6 \%\end{array}$ & $\begin{array}{l}186 \\
22.2 \% \\
13.3 \% \\
3.0 \%\end{array}$ & $\begin{array}{l}188 \\
22.5 \% \\
12.2 \% \\
3.0 \%\end{array}$ & $\begin{array}{l}146 \\
17.5 \% \\
11.9 \% \\
2.4 \%\end{array}$ & $\begin{array}{l}836 \\
100.0 \% \\
13.6 \% \\
13.6 \%\end{array}$ \\
\hline $\begin{array}{l}\text { Student Count } \\
\% \text { within Students } \\
\% \text { within Newspaper } \\
\% \text { of Total }\end{array}$ & $\begin{array}{l}289 \\
13.6 \% \\
29.8 \% \\
4.7 \%\end{array}$ & $\begin{array}{l}350 \\
16.4 \% \\
33.9 \% \\
5.7 \%\end{array}$ & $\begin{array}{l}491 \\
23.0 \% \\
35.0 \% \\
8.0 \%\end{array}$ & $\begin{array}{l}560 \\
26.3 \% \\
36.4 \% \\
9.1 \%\end{array}$ & $\begin{array}{l}442 \\
20.7 \% \\
36.2 \% \\
7.2 \%\end{array}$ & $\begin{array}{l}2132 \\
100.0 \% \\
34.6 \% \\
34.6 \%\end{array}$ \\
\hline $\begin{array}{l}\text { Com. Enterprise Count } \\
\% \text { within Com. Enterprise } \\
\% \text { within Newspaper } \\
\% \text { of Total }\end{array}$ & $\begin{array}{l}26 \\
9.6 \% \\
2.7 \% \\
.4 \%\end{array}$ & $\begin{array}{l}43 \\
15.9 \% \\
4.2 \% \\
.7 \%\end{array}$ & $\begin{array}{l}50 \\
18.5 \% \\
3.6 \% \\
.8 \%\end{array}$ & $\begin{array}{l}74 \\
27.4 \% \\
4.8 \% \\
1.2 \%\end{array}$ & $\begin{array}{l}77 \\
28.5 \% \\
6.3 \% \\
1.2 \%\end{array}$ & $\begin{array}{l}270 \\
100.0 \% \\
4.4 \% \\
4.4 \%\end{array}$ \\
\hline $\begin{array}{l}\text { Finance Count } \\
\% \text { within Finance } \\
\% \text { within Newspapers } \\
\% \text { of Total }\end{array}$ & $\begin{array}{l}66 \\
29.1 \% \\
6.8 \% \\
1.1 \%\end{array}$ & $\begin{array}{l}42 \\
18.5 \% \\
4.1 \% \\
.7 \%\end{array}$ & $\begin{array}{l}53 \\
23.3 \% \\
3.8 \% \\
.9 \%\end{array}$ & $\begin{array}{l}45 \\
19.8 \% \\
2.9 \% \\
.7 \%\end{array}$ & $\begin{array}{l}21 \\
9.3 \% \\
1.7 \% \\
.3 \%\end{array}$ & $\begin{array}{l}227 \\
100.0 \% \\
3.7 \% \\
3.7 \%\end{array}$ \\
\hline $\begin{array}{l}\text { Curriculum Count } \\
\% \text { within Curriculum } \\
\% \text { within Newspaper } \\
\% \text { of Total }\end{array}$ & $\begin{array}{l}68 \\
27.0 \% \\
7.0 \% \\
1.1 \%\end{array}$ & $\begin{array}{l}37 \\
14.7 \% \\
3.6 \% \\
.6 \%\end{array}$ & $\begin{array}{l}65 \\
25.8 \% \\
4.6 \% \\
1.1 \%\end{array}$ & $\begin{array}{l}39 \\
15.5 \% \\
2.5 \% \\
.6 \%\end{array}$ & $\begin{array}{l}43 \\
17.1 \% \\
3.5 \% \\
.7 \%\end{array}$ & $\begin{array}{l}252 \\
100.0 \% \\
4.1 \% \\
4.1 \%\end{array}$ \\
\hline $\begin{array}{l}\text { General Count } \\
\% \text { within General } \\
\% \text { within Newspaper } \\
\% \text { of Total }\end{array}$ & $\begin{array}{l}16 \\
17.8 \% \\
1.6 \% \\
.3 \%\end{array}$ & $\begin{array}{l}15 \\
16.7 \% \\
1.5 \% \\
.2 \%\end{array}$ & $\begin{array}{l}17 \\
18.9 \% \\
1.2 \% \\
.3 \%\end{array}$ & $\begin{array}{l}15 \\
16.7 \% \\
1.0 \% \\
.2 \%\end{array}$ & $\begin{array}{l}27 \\
30.0 \% \\
2.2 \% \\
.4 \%\end{array}$ & $\begin{array}{l}90 \\
100.0 \% \\
1.5 \% \\
1.5 \%\end{array}$ \\
\hline $\begin{array}{l}\text { Maori Ed. Count } \\
\% \text { within Maori Ed } \\
\% \text { within Newspaper } \\
\% \text { of Total }\end{array}$ & $\begin{array}{l}33 \\
28.9 \% \\
3.4 \% \\
.5 \%\end{array}$ & $\begin{array}{l}20 \\
17.5 \% \\
1.9 \% \\
.3 \%\end{array}$ & $\begin{array}{l}30 \\
26.3 \% \\
2.1 \% \\
.5 \%\end{array}$ & $\begin{array}{l}14 \\
12.3 \% \\
.9 \% \\
.2 \%\end{array}$ & $\begin{array}{l}17 \\
14.9 \% \\
1.4 \% \\
.3 \%\end{array}$ & $\begin{array}{l}114 \\
100.0 \% \\
1.8 \% \\
1.8 \%\end{array}$ \\
\hline $\begin{array}{l}\text { Ed. Purpose Count } \\
\% \text { within Ed. Purpose } \\
\% \text { within Newspaper } \\
\% \text { of Total }\end{array}$ & $\begin{array}{l}7 \\
63.6 \% \\
.7 \% \\
.1 \%\end{array}$ & $\begin{array}{l}1 \\
9.1 \% \\
.1 \% \\
.0 \%\end{array}$ & $\begin{array}{l}2 \\
18.2 \% \\
.1 \% \\
.0 \%\end{array}$ & & $\begin{array}{l}1 \\
9.1 \% \\
.1 \% \\
.0 \%\end{array}$ & $\begin{array}{l}11 \\
100.0 \% \\
.2 \% \\
.2 \%\end{array}$ \\
\hline \multicolumn{7}{|l|}{$\begin{array}{l}\text { Language Count } \\
\% \text { within Language } \\
\% \text { within Newspaper } \\
\% \text { of Total }\end{array}$} \\
\hline $\begin{array}{l}\text { Total Count } \\
\% \text { within Newspaper } \\
\% \text { of Total }\end{array}$ & $\begin{array}{l}971 \\
100.0 \% \\
15.7 \%\end{array}$ & $\begin{array}{l}1033 \\
100.0 \% \\
16.8 \%\end{array}$ & $\begin{array}{l}1402 \\
100.0 \% \\
22.7 \%\end{array}$ & $\begin{array}{l}1538 \\
100.0 \% \\
24.9 \%\end{array}$ & $\begin{array}{l}1222 \\
100.0 \% \\
19.8 \%\end{array}$ & $\begin{array}{l}6166 \\
100.0 \% \\
100.0 \%\end{array}$ \\
\hline
\end{tabular}


There were considerably less story contents for commercial enterprise (270), curriculum (252) and finance (227). There were even fewer for story content articles on Maori education (114), institution building (95), general (90) and educational purpose (11). There were no articles published in the story content for language in any of the newspapers; and there were no publications for the story content category education purpose in The Otago Daily Times during this period.

\section{Students}

The Otago Daily Times had the most articles within this category with 560 publications. The Press published 491 articles, 3\% fewer than The Otago Daily Times (Table 6.3.1). The Southland Times published 442 articles about students, which were 3\% less than The Press. In all, the South Island papers published $70 \%$ of the story content about students (Table 6.3.1). North Island papers published the remaining 30\% with The Evening Post having 350 student articles, while The New Zealand Herald had least student story content with 289 articles.

\section{Institution}

The results showed that all South Island papers were concerned with institution story contents. The Otago Daily Times, The Press and The Southland Times published 393, 310 and 254 articles respectively (Table 6.3.1). Their combined total represented 75\% of this story content. The Evening Post published 174 articles, while The New Zealand Herald had the least with 144 articles.

\section{Administration}

This was the third most published story content representing $14.0 \%$ of all newspaper story contents during the 12 year period (Table 6.3.1). The Otago Daily Times published the most with 208 articles. The Southland Times, The Evening Post and The New Zealand Herald published 176, 149 and 141 respectively. 


\section{Staff}

This story content category had little variation in the number of articles published across all the five newspapers surveyed. The two North Island papers each published 158 articles. The Press (186) and The Otago Daily Times (188) were also close in their published articles. The Southland Times published least with 146 articles. The total count of all newspaper articles published in this category came to $13.6 \%$.

\section{Commercial Enterprise}

The Southland Times and The Otago Daily Times had the most publications with 77 and 74 respectively. The Press followed with 50 articles. The combined total of the three South Island papers closely represented $75 \%$ of the commercial enterprise articles published. The remaining 25\% were divided unequally between The Evening Post (43) and The New Zealand Herald (26). Although there is a division among the newspapers regarding the number of articles published in this category, the total count for all newspaper articles published was $4.4 \%$ of all story content categories.

\section{Curriculum}

This story content category represented $4.1 \%$ for the total count of all story content articles. The New Zealand Herald published 68 articles, while The Press published 65. The remaining three papers had a fairly even distribution of articles published: The Southland Times (43), The Otago Daily Times (39) and The Evening Post (37).

\section{Finance}

The New Zealand Herald published the most articles in this story category with a total of 66 during the 12-year period. The Press followed with 53, while The Otago Daily Times and The Evening Post published 45 and 42 respectively. The Southland Times had least with 21 publications. Comparing the commercial enterprise and finance categories there is a reversal in the number of publications between The New Zealand Herald and The Southland Times, although the two categories are closely linked. 


\section{Miscellaneous}

The remaining four story content categories represent five per cent of the total story count within all newspapers. Of these remaining categories Maori education had the highest count of 1.8 per cent within the total newspaper count. Second equal were the institution building and general story content categories with each having a count of 1.5 per cent. The education purpose story content count was 0.2 per cent while, as already noted, the language story content had no entries from any of the five newspapers.

\section{Summary of newspaper by Story Content}

The South Island newspapers were found to predominate in the five most frequently published story contents (students, institution, administration, staff, and commercial enterprise). There was an inverse number of publications in the finance and commercial enterprise story contents between The New Zealand Herald and The Southland Times, yet the two story contents were closely linked. The New Zealand Herald published 63.3\% of the education purpose story content while The Otago Daily Times had no publications in this category. Articles about Maori education had a count 1.8 per cent. There were no publications in the language story content.

\subsubsection{Budd Score by Newstype \\ Overview of Budd Score by Newstype}

The results of Budd score by newstype are summarised in Table 6.3.2. As already noted, the results show that the most frequent Budd score for the education articles surveyed was two, with a total of 2906 (47.1\%) newspaper articles. Newspaper articles with a Budd score of one closely followed with a total of 2160 articles (35\%). There were 844 articles with a Budd score of three (13.7\%), 225 articles with a Budd score of four (3.6\%) and 31 articles about education with a Budd score of five $(0.5 \%)$.

\section{News}

The most frequent newstype found was news with a total of 4293 articles (Table 6.3.2). Over half these articles, a total of 2431, were found to have Budd scores of two. A further 1497 articles had a Budd score of one. Their 
combined total count within news made up $91.5 \%$ of all news contents, while their Budd scores counted for $69.6 \%$ of all Budd scores by newstype.

\section{Photos}

This newstype was the second most frequently used newstype with 1813 items, which represented almost 30\% of the total newstype count. In keeping with the news newstype, photo newstype was also found with lower Budd scores. Photos with a Budd score of two and a Budd score of one had 859 and 585 photos respectively. This newstype was found to have 20 articles with a Budd score of five and 96 with a Budd score of four.

\section{Main Page News}

This newstype had a total count of 707 articles. Main page news represented $11.5 \%$ of the total newstype count and was the third largest newtype. Within the total count of Budd score of four, 139 were main page news articles. This accounted for $61.8 \%$ of all newspaper articles with a Budd score of four.

\section{Letters}

The total count for this newstype was 684 with 522 (76.3\%) with a Budd score of one. No letters were published in any of the newspapers with a Budd score of five. Nineteen were found with a Budd score of four.

\section{Cartoons}

This was the least published newstype with 13 articles found. There were no cartoons with Budd scores three, four or five. Seven cartoons had a Budd score of two, while the remaining six had Budd scores of one.

\section{Budd Score Four}

There were 225 articles found with a Budd score of four. Main page news had 139 articles within this score, representing $61.8 \%$ of all articles with a Budd score of four. Features were next with 76 articles, followed by expert comment (37). The three least newstypes published with a Budd score of four were editorial (5), pupil/student contribution (1) and cartoons with no publications. 


\section{Budd Score Five}

The newstype feature had the highest number of articles with a Budd score of five with a total of 23. News and main page news had five and three respectively, while pupil/student contribution had two. Editorials and expert comment newstypes each had one article with a Budd score of five. There were no letters or cartoons with a Budd score of five published in any of the newspapers.

\section{Summary of Budd Score by Newstype}

Predominantly, the most frequent Budd scores were in the 1-2 score range making 82.1\% of all Budd scores. News (4293), photos (1813) and main page news (707) were the most frequent newstypes. No articles with a Budd score of five were found in the letters newstype. Cartoons had the least publications (13) and they were evenly distributed between Budd scores one and two.

\subsubsection{Story Content by Budd Score \\ Overview of Story Content by Budd Score}

The results of story contents by Budd score are presented in Table 6.3.3. The most frequently most frequently occurring story content was the student story content with 2132 articles. The second most frequent story content published, with 1275 articles, was institution. Administration and staff followed with 864 and 836 articles respectively. Commercial enterprise (270), curriculum (252) and finance (227) had similar article counts. The least published story content categories, in descending order were, Maori education (114), institution building (95) and general (90). There were no story content articles for language. Furthermore, there were no story contents for institution building, staff, finance, Maori education and education purpose with a Budd score of five. 
Table 6.3.2 Summary of Budd Score by Newstype: 1988-1999.

\begin{tabular}{|c|c|c|c|c|c|c|}
\hline Newstype & $\begin{array}{l}1 \text { Budd } \\
\text { Score }\end{array}$ & $\begin{array}{l}2 \text { Budd } \\
\text { Score }\end{array}$ & $\begin{array}{l}\text { Budd } \\
\text { Score }\end{array}$ & $\begin{array}{l}4 \text { Budd } \\
\text { Score }\end{array}$ & $\begin{array}{l}5 \text { Budd } \\
\text { Score }\end{array}$ & Total \\
\hline $\begin{array}{l}\text { Editorial Count } \\
\text { \% within Editorial } \\
\% \text { within Budd Score } \\
\% \text { of total }\end{array}$ & $\begin{array}{l}8 \\
5.5 \% \\
.4 \% \\
.1 \%\end{array}$ & $\begin{array}{l}34 \\
23.4 \% \\
1.2 \% \\
.6 \%\end{array}$ & $\begin{array}{l}97 \\
66.9 \% \\
11.5 \% \\
1.6 \%\end{array}$ & $\begin{array}{l}5 \\
3.4 \% \\
2.2 \% \\
.1 \%\end{array}$ & $\begin{array}{l}1 \\
.7 \% \\
3.2 \% \\
.0 \%\end{array}$ & $\begin{array}{l}145 \\
100.0 \% \\
2.4 \% \\
2.4 \%\end{array}$ \\
\hline $\begin{array}{l}\text { Main Page News Count } \\
\% \text { within MPN } \\
\% \text { within Budd Score } \\
\% \text { of Total }\end{array}$ & $\begin{array}{l}65 \\
9.2 \% \\
3.0 \% \\
1.1 \%\end{array}$ & $\begin{array}{l}239 \\
33.8 \% \\
8.2 \% \\
3.9 \%\end{array}$ & $\begin{array}{l}261 \\
36.9 \% \\
30.9 \% \\
4.2 \%\end{array}$ & $\begin{array}{l}139 \\
19.7 \% \\
61.8 \% \\
2.3 \%\end{array}$ & $\begin{array}{l}3 \\
.4 \% \\
9.7 \% \\
.0 \%\end{array}$ & $\begin{array}{l}707 \\
100.0 \% \\
11.5 \% \\
11.5 \%\end{array}$ \\
\hline $\begin{array}{l}\text { Features Count } \\
\text { \% within features } \\
\text { \% within Budd Score } \\
\text { \% of Total }\end{array}$ & $\begin{array}{l}25 \\
8.1 \% \\
1.2 \% \\
.4 \%\end{array}$ & $\begin{array}{l}95 \\
30.9 \% \\
3.3 \% \\
1.5 \%\end{array}$ & $\begin{array}{l}88 \\
28.7 \% \\
10.4 \% \\
1.4 \%\end{array}$ & $\begin{array}{l}76 \\
24.8 \% \\
33.8 \% \\
1.2 \%\end{array}$ & $\begin{array}{l}23 \\
7.5 \% \\
74.2 \% \\
.4 \%\end{array}$ & $\begin{array}{l}307 \\
100.0 \% \\
5.0 \% \\
5.0 \%\end{array}$ \\
\hline $\begin{array}{l}\text { News Count } \\
\text { \% within News } \\
\% \text { within Budd Score } \\
\text { \% of Total }\end{array}$ & $\begin{array}{l}1497 \\
34.9 \% \\
69.3 \% \\
24.3 \%\end{array}$ & $\begin{array}{l}2431 \\
56.6 \% \\
83.7 \% \\
39.4 \%\end{array}$ & $\begin{array}{l}337 \\
7.8 \% \\
39.9 \% \\
5.5 \%\end{array}$ & $\begin{array}{l}23 \\
.5 \% \\
10.2 \% \\
.4 \%\end{array}$ & $\begin{array}{l}5 \\
.1 \% \\
16.1 \% \\
.1 \%\end{array}$ & $\begin{array}{l}4293 \\
100.0 \% \\
69.6 \% \\
69.6 \%\end{array}$ \\
\hline $\begin{array}{l}\text { Letters Count } \\
\text { \% within Letters } \\
\% \text { within Budd Score } \\
\text { \% of Total }\end{array}$ & $\begin{array}{l}522 \\
76.3 \% \\
24.2 \% \\
8.5 \%\end{array}$ & $\begin{array}{l}82 \\
12.0 \% \\
2.8 \% \\
1.3 \%\end{array}$ & $\begin{array}{l}61 \\
8.9 \% \\
7.2 \% \\
1.0 \%\end{array}$ & $\begin{array}{l}19 \\
2.8 \% \\
8.4 \% \\
.3 \%\end{array}$ & & $\begin{array}{l}684 \\
100.0 \% \\
11.1 \% \\
11.1 \%\end{array}$ \\
\hline $\begin{array}{l}\text { Expert Comment Count } \\
\text { \% within Expert comment } \\
\text { \% within Budd Score } \\
\text { \% of Total }\end{array}$ & $\begin{array}{l}61 \\
29.8 \% \\
2.8 \% \\
1.0 \%\end{array}$ & $\begin{array}{l}61 \\
29.8 \% \\
2.1 \% \\
1.0 \%\end{array}$ & $\begin{array}{l}45 \\
22.0 \% \\
5.3 \% \\
.7 \%\end{array}$ & $\begin{array}{l}37 \\
18.0 \% \\
16.4 \% \\
.6 \%\end{array}$ & $\begin{array}{l}1 \\
.5 \% \\
3.2 \% \\
.0 \%\end{array}$ & $\begin{array}{l}205 \\
100.0 \% \\
3.3 \% \\
3.3 \%\end{array}$ \\
\hline $\begin{array}{l}\text { Photo Count } \\
\% \text { within Photo } \\
\% \text { within Budd Score } \\
\% \text { of Total }\end{array}$ & $\begin{array}{l}585 \\
32.3 \% \\
27.1 \% \\
9.5 \%\end{array}$ & $\begin{array}{l}859 \\
47.4 \% \\
29.6 \% \\
13.9 \%\end{array}$ & $\begin{array}{l}253 \\
14.0 \% \\
30.0 \% \\
4.1 \%\end{array}$ & $\begin{array}{l}96 \\
5.3 \% \\
42.7 \% \\
1.6 \%\end{array}$ & $\begin{array}{l}20 \\
1.1 \% \\
64.5 \% \\
.3 \%\end{array}$ & $\begin{array}{l}1813 \\
100.0 \% \\
29.4 \% \\
29.4 \%\end{array}$ \\
\hline $\begin{array}{l}\text { Cartoon Count } \\
\% \text { within Cartoon } \\
\% \text { within Budd Score } \\
\% \text { of Total }\end{array}$ & $\begin{array}{l}6 \\
46.2 \% \\
.3 \% \\
.1 \%\end{array}$ & $\begin{array}{l}7 \\
53.8 \% \\
.2 \% \\
.1 \%\end{array}$ & & & & $\begin{array}{l}13 \\
100.0 \% \\
.2 \% \\
.2 \%\end{array}$ \\
\hline $\begin{array}{l}\text { Pupil/student Count } \\
\text { \% within Pupil/Student } \\
\text { Contribution } \\
\% \text { within Budd Score } \\
\% \text { of Total }\end{array}$ & $\begin{array}{l}19 \\
42.2 \% \\
.9 \% \\
.3 \%\end{array}$ & $\begin{array}{l}14 \\
31.1 \% \\
.5 \% \\
.2 \%\end{array}$ & $\begin{array}{l}9 \\
20.0 \% \\
1.1 \% \\
.1 \%\end{array}$ & $\begin{array}{l}1 \\
2.2 \% \\
.4 \% \\
.0 \%\end{array}$ & $\begin{array}{l}2 \\
4.4 \% \\
6.5 \% \\
.0 \%\end{array}$ & $\begin{array}{l}45 \\
100.0 \% \\
.7 \% \\
.7 \%\end{array}$ \\
\hline $\begin{array}{l}\text { Total Count } \\
\text { \% within Budd Score } \\
\text { \% of Total }\end{array}$ & $\begin{array}{l}2160 \\
100.0 \% \\
35.0 \%\end{array}$ & $\begin{array}{l}2906 \\
100.0 \% \\
47.1 \%\end{array}$ & $\begin{array}{l}844 \\
100.0 \% \\
13.7 \%\end{array}$ & $\begin{array}{l}225 \\
100.0 \% \\
3.6 \%\end{array}$ & $\begin{array}{l}31 \\
100.0 \% \\
.5 \%\end{array}$ & $\begin{array}{l}6166 \\
100.0 \% \\
100.0 \%\end{array}$ \\
\hline
\end{tabular}


Table 6.3.3 Summary of Story Content by Budd Score: 1988-1999.

\begin{tabular}{|c|c|c|c|c|c|c|}
\hline Story Content & $\begin{array}{l}1 \text { Budd } \\
\text { Score }\end{array}$ & $\begin{array}{l}2 \text { Budd } \\
\text { Score }\end{array}$ & $\begin{array}{l}3 \text { Budd } \\
\text { Score }\end{array}$ & $\begin{array}{l}4 \text { Budd } \\
\text { Score }\end{array}$ & $\begin{array}{l}5 \text { Budd } \\
\text { Score }\end{array}$ & Total \\
\hline $\begin{array}{l}\text { Administration Count } \\
\text { \% within Admin. } \\
\text { \% within Budd Score } \\
\text { \% of Total }\end{array}$ & $\begin{array}{l}256 \\
29.6 \% \\
11.9 \% \\
4.2 \%\end{array}$ & $\begin{array}{l}418 \\
48.4 \% \\
14.4 \% \\
6.8 \%\end{array}$ & $\begin{array}{l}138 \\
16.0 \% \\
16.4 \% \\
2.2 \%\end{array}$ & $\begin{array}{l}46 \\
5.3 \% \\
20.4 \% \\
.7 \%\end{array}$ & $\begin{array}{l}6 \\
.7 \% \\
19.4 \% \\
.1 \%\end{array}$ & $\begin{array}{l}864 \\
100.0 \% \\
14.0 \% \\
14.0 \%\end{array}$ \\
\hline $\begin{array}{l}\text { Institution Count } \\
\% \text { within Institution } \\
\% \text { within Budd Score } \\
\% \text { of Total }\end{array}$ & $\begin{array}{l}422 \\
33.1 \% \\
19.5 \% \\
6.8 \%\end{array}$ & $\begin{array}{l}643 \\
50.4 \% \\
22.1 \% \\
10.4 \%\end{array}$ & $\begin{array}{l}164 \\
12.9 \% \\
19.4 \% \\
2.7 \%\end{array}$ & $\begin{array}{l}41 \\
3.2 \% \\
18.2 \% \\
.7 \%\end{array}$ & $\begin{array}{l}5 \\
.4 \% \\
16.1 \% \\
.1 \%\end{array}$ & $\begin{array}{l}1275 \\
100.0 \% \\
20.7 \% \\
20.7 \%\end{array}$ \\
\hline $\begin{array}{l}\text { Institution Build. Count } \\
\text { \% within Instit. Building } \\
\text { \% within Budd Score } \\
\% \text { of Total }\end{array}$ & $\begin{array}{l}33 \\
34.7 \% \\
1.5 \% \\
.5 \%\end{array}$ & $\begin{array}{l}38 \\
40.0 \% \\
1.3 \% \\
.6 \%\end{array}$ & $\begin{array}{l}20 \\
21.1 \% \\
2.4 \% \\
.3 \%\end{array}$ & $\begin{array}{l}4 \\
4.2 \% \\
1.8 \% \\
.1 \%\end{array}$ & & $\begin{array}{l}95 \\
100.0 \% \\
1.5 \% \\
1.5 \%\end{array}$ \\
\hline $\begin{array}{l}\text { Staff } \\
\% \text { within Staff } \\
\% \text { within Budd Score } \\
\% \text { of Total }\end{array}$ & $\begin{array}{l}295 \\
35.3 \% \\
13.7 \% \\
4.8 \%\end{array}$ & $\begin{array}{l}409 \\
48.9 \% \\
14.1 \% \\
6.6 \%\end{array}$ & $\begin{array}{l}106 \\
12.7 \% \\
12.6 \% \\
1.7 \%\end{array}$ & $\begin{array}{l}26 \\
3.1 \% \\
11.6 \% \\
.4 \%\end{array}$ & & $\begin{array}{l}836 \\
100.0 \% \\
13.6 \% \\
13.6 \%\end{array}$ \\
\hline $\begin{array}{l}\text { Students Count } \\
\% \text { within Students } \\
\% \text { within Budd Score } \\
\% \text { of Total }\end{array}$ & $\begin{array}{l}808 \\
37.9 \% \\
37.4 \% \\
13.1 \%\end{array}$ & $\begin{array}{l}977 \\
45.8 \% \\
33.6 \% \\
15.8 \%\end{array}$ & $\begin{array}{l}265 \\
12.4 \% \\
31.4 \% \\
4.3 \%\end{array}$ & $\begin{array}{l}66 \\
3.1 \% \\
29.3 \% \\
1.1 \%\end{array}$ & $\begin{array}{l}16 \\
.8 \% \\
51.6 \% \\
.3 \%\end{array}$ & $\begin{array}{l}2132 \\
100.0 \% \\
34.6 \% \\
34.6 \%\end{array}$ \\
\hline $\begin{array}{l}\text { Commercial Ent. Count } \\
\text { \% within Commercial Ent } \\
\% \text { within Budd Score } \\
\% \text { of Total }\end{array}$ & $\begin{array}{l}86 \\
31.9 \% \\
4.0 \% \\
1.4 \%\end{array}$ & $\begin{array}{l}137 \\
50.7 \% \\
4.7 \% \\
2.2 \%\end{array}$ & $\begin{array}{l}39 \\
14.4 \% \\
4.6 \% \\
.6 \%\end{array}$ & $\begin{array}{l}6 \\
2.2 \% \\
2.7 \% \\
.1 \%\end{array}$ & $\begin{array}{l}2 \\
.7 \% \\
6.5 \% \\
.0 \%\end{array}$ & $\begin{array}{l}270 \\
100.0 \% \\
4.4 \% \\
4.4 \%\end{array}$ \\
\hline $\begin{array}{l}\text { Finance Count } \\
\text { \% within Finance } \\
\% \text { within Budd Score } \\
\% \text { of Total }\end{array}$ & $\begin{array}{l}76 \\
33.5 \% \\
3.5 \% \\
1.2 \%\end{array}$ & $\begin{array}{l}98 \\
43.2 \% \\
3.4 \% \\
1.6 \%\end{array}$ & $\begin{array}{l}37 \\
16.3 \% \\
4.4 \% \\
.6 \%\end{array}$ & $\begin{array}{l}16 \\
7.0 \% \\
7.1 \% \\
.3 \%\end{array}$ & & $\begin{array}{l}227 \\
100.0 \% \\
3.7 \% \\
3.7 \%\end{array}$ \\
\hline $\begin{array}{l}\text { Curriculum Count } \\
\% \text { within Curriculum } \\
\% \text { within Budd Score } \\
\% \text { of Total }\end{array}$ & $\begin{array}{l}97 \\
38.5 \% \\
4.5 \% \\
1.6 \%\end{array}$ & $\begin{array}{l}97 \\
38.5 \% \\
3.3 \% \\
1.6 \%\end{array}$ & $\begin{array}{l}44 \\
17.5 \% \\
5.2 \% \\
.7 \%\end{array}$ & $\begin{array}{l}13 \\
5.2 \% \\
5.8 \% \\
.2 \%\end{array}$ & $\begin{array}{l}1 \\
.4 \% \\
3.2 \% \\
.0 \%\end{array}$ & $\begin{array}{l}252 \\
100.0 \% \\
4.1 \% \\
4.1 \%\end{array}$ \\
\hline $\begin{array}{l}\text { General Count } \\
\% \text { within General } \\
\% \text { within Budd Score } \\
\% \text { of Total }\end{array}$ & $\begin{array}{l}34 \\
37.8 \% \\
1.6 \% \\
.6 \%\end{array}$ & $\begin{array}{l}40 \\
44.4 \% \\
1.4 \% \\
.6 \%\end{array}$ & $\begin{array}{l}13 \\
14.4 \% \\
1.5 \% \\
.2 \%\end{array}$ & $\begin{array}{l}2 \\
2.2 \% \\
.9 \% \\
.0 \%\end{array}$ & $\begin{array}{l}1 \\
1.1 \% \\
3.2 \% \\
.0 \%\end{array}$ & $\begin{array}{l}90 \\
100.0 \% \\
1.5 \% \\
1.5 \%\end{array}$ \\
\hline $\begin{array}{l}\text { Maori Ed. Count } \\
\% \text { within Maori Ed. } \\
\% \text { within Budd Score } \\
\% \text { of Total }\end{array}$ & $\begin{array}{l}46 \\
40.4 \% \\
2.1 \% \\
.7 \%\end{array}$ & $\begin{array}{l}48 \\
42.1 \% \\
1.7 \% \\
.8 \%\end{array}$ & $\begin{array}{l}17 \\
14.9 \% \\
2.0 \% \\
.3 \%\end{array}$ & $\begin{array}{l}3 \\
2.6 \% \\
1.3 \% \\
.0 \%\end{array}$ & & $\begin{array}{l}114 \\
100.0 \% \\
.1 .8 \% \\
1.8 \%\end{array}$ \\
\hline $\begin{array}{l}\text { Ed. Purpose Count } \\
\text { \% within Ed. Purpose } \\
\% \text { within Budd Score } \\
\% \text { of Total }\end{array}$ & $\begin{array}{l}7 \\
63.6 \% \\
.3 \% \\
.1 \%\end{array}$ & $\begin{array}{l}1 \\
9.1 \% \\
.0 \% \\
.0 \%\end{array}$ & $\begin{array}{l}1 \\
9.1 \% \\
.1 \% \\
.0 \%\end{array}$ & $\begin{array}{l}2 \\
18.2 \% \\
.9 \% \\
.0 \%\end{array}$ & & $\begin{array}{l}11 \\
100.0 \% \\
.2 \% \\
.2 \%\end{array}$ \\
\hline \multicolumn{7}{|l|}{$\begin{array}{l}\text { Language Count } \\
\text { \% within Language } \\
\text { \% within Budd Score } \\
\% \text { of Total }\end{array}$} \\
\hline $\begin{array}{l}\text { Total Count } \\
\text { \% within Budd Score } \\
\% \text { of Total }\end{array}$ & $\begin{array}{l}2160 \\
100.0 \% \\
35.0 \%\end{array}$ & $\begin{array}{l}2906 \\
100.0 \% \\
47.1 \%\end{array}$ & $\begin{array}{l}844 \\
100.0 \% \\
13.7 \%\end{array}$ & $\begin{array}{l}225 \\
100.0 \% \\
3.6 \%\end{array}$ & $\begin{array}{l}31 \\
100.0 \% \\
.5 \%\end{array}$ & $\begin{array}{l}6166 \\
100.0 \% \\
100.0 \%\end{array}$ \\
\hline
\end{tabular}




\section{Budd Scores One and Two}

The most frequently occurring Budd score was two with a total count of 2906 newspaper articles. The second most frequent Budd score was one with a total count of 2160. As noted earlier these two Budd scores represented over $80 \%$ of the total count of Budd scores. If Budd scores one and two are combined, the student and institution story contents are the two highest categories (1785 and 1065 publications respectively). Although there is greater variation between the staff story contents of Budd score counts of one and two, their combined figures show this was the third most frequently published story content with 295 and 409 articles respectively. Similarly, when the administration story content counts of Budd score one (256) are combined with Budd score two (418 articles), it was found this story content provided the fourth most frequently published newspaper articles. The fifth most frequently published story content, commercial enterprise also showed variation between Budd scores one (86) and two (137). There was less variation between finance Budd scores one (76) and two (98). Curriculum, Maori education, institution building and general story contents had similar Budd scores between one and two within each of their categories. Furthermore, this last group of five story contents was, in descending order, the least frequently published.

\section{Budd Score Three}

Within this Budd score the most frequent story content was students with 265 publications. This was followed with institution (164), administration (138) and staff (106) story contents. Curriculum, commercial enterprise and finance cluster around the 33-44 count, while Maori education and general story contents were 17 and 13 respectively. Education purpose had one entry only. There were no entries for language story content.

\section{Budd Score Four}

There are 225 story contents with a Budd score of four. This contributes 3.6\% of the total Budd score (Table 6.3.3). The student story content had the most articles with 66 in all. The second and third stories content categories were administration (46) and institution (41). There were five story contents with 
the least articles published. In descending order they were, commercial enterprise (6), institution buildings (4), Maori education (3) general (2) and education purpose (2). There were no articles for language story content.

\section{Budd Score Five}

Within the Budd score of five a total of 31 education articles were published. This represents $0.5 \%$ of the total Budd scores (Table 6.3.3). The most frequently occurring story content was students (16), which made $51 \%$ of the publications within this Budd score. Administration had six publications and was closely followed by institution, which had five publications. Commercial enterprise had two articles, while curriculum and general story contents had one article each. There were no Budd scores of five for institution building, staff, finance, education purpose, language and, most notably, Maori education.

\subsection{Summary of Story Contents by Budd Score}

Predominantly, story contents were found within the Budd scores of one and two with students' story content contributing over $30 \%$ of the articles published within those score ranges. Thereafter, there is a sharp decrease in education articles appearing in the higher Budd scores. Budd score three had 844 education articles, Budd score four 225, and Budd score five had the least education story content with 31 publications. Most notable is the number of education story contents found with a Budd score of five, which represents 0.5\% of the Budd score total. Fifty one per cent of story contents with a Budd score of five focus on students (16). There is a marked decrease for other story content categories. Administration (6) and institution (5) are the second and third most published categories. Commercial enterprise (2), curriculum (1) and general (1) make up the balance. There are no Budd score five publications for institution building, staff, finance, education purpose, language and, significantly, Maori education. 


\section{CHAPTER SEVEN - RESULTS AND ANALYSES FROM BUDD SCORE FOUR AND FIVE NEWSPAPER ARTICLES}

\subsection{Introduction}

This chapter presents analyses of the findings in the five major daily newspapers surveyed that had a Budd score of four or five during the 19881999 period. In the previous chapter a descriptive analysis was provided. This chapter will focus on the story content, the story subcontent, and where relevant, the newstype and locality. This chapter will present the analyses of the results in four sections:

- Overview of Budd score four results, locality and newstype summary

- Analysis by story content and story subcontent

- Overview of Budd score five results, locality and newstype summary

- Analysis by story content and story subcontent

A summary of the findings provided by Budd scores four and five will conclude each section.

\subsection{Overview of Budd Score Four results}

Because there was a large volume of results with a Budd score of four, a summary of the newspapers' story contents, subcontents, news type, locality and year are presented in the Appendices, Tables A.7: 1- A.7: 12. Please note it was possible for an article to have more than one newstype. The tables in the appendices show the dominant newstype only, while photos have been treated as part of the text.

\subsubsection{Story Content}

In all, 225 articles were found with a Budd score of four. The predominant three story contents were students (66), administration (46) and institution (41). The staff, finance and curriculum story contents followed with 26, 16 and 13 articles respectively. The least published story contents were commercial enterprise (6), institution buildings (4), Maori education (3), general (2) and education purpose (2). There were no publications for the language story 
content. Furthermore, The Southland Times and The Press had no articles published with a Budd score of four in 1988 and 1989 respectively.

\subsubsection{Newstype and Locality}

In terms of newstype, main page news provided $61.8 \%$ of all the Budd score four story contents. Features and expert comment with $33.8 \%$ and $16.4 \%$ followed this respectively, while letters (19) represented $2.8 \%$ of the total Budd score four count. Editorials were largely absent with only five publications with a Budd score of four and provided 3.4\% of all editorial counts. Finally, only one pupil/student contribution was found within this Budd score.

Locality was predominantly from local sources (179), which contributed $79.6 \%$ of publications with a Budd score of four. The other two localities, national (33) and international (13), contributed $14.7 \%$ and $5.8 \%$ respectively. The New Zealand Herald had the most publications with 58 (25.8\%) articles. The Otago Daily Times followed with 53 (23.6\%). The Evening Post, The Press and The Southland Times had 40 (17.8\%), 38 (16.9\%) and 36 (16.0\%) publications respectively. The most nationally sourced publications were found in The Otago Daily Times (9), The Press (8) and The New Zealand Herald (7). All newspapers had at least one publication from an international source. As noted, this source contributed $5.8 \%$ of all Budd score four publications. The Southland Times however, contributed $38.5 \%$ of all international news sources.

\subsection{Story Content by Subcontent}

The results found seven story contents with a Budd score of four. These were, in descending order of articles, students, administration, staff, finance, curriculum and miscellaneous. This section discusses each story content and their respective subcontents. A summary will conclude this section.

\subsubsection{Story Content: Students}

The most frequently published story content was students with a Budd score of four. Within this story content the two most frequently published subcontents were health (15) and student achievements (14). Other common subcontents 
included student funding (10), student protest, conflict (9) and student discipline (7). Less common were articles on university life (3), plays and a music festival (3), extracurricular enterprise and contributions (3) and computers (2).

\section{Health}

Within the health subcontent the newspaper articles were evenly dispersed with 15 articles being placed as main page news. Nine of the stories focused on acts of violence, including the Aramoana shooting in which one of the victims, a child, was "keen to return to school” (Otago Daily Times, 19 November, 1990). Six of the nine stories were from international sources that reported on topics such as The Dunblane School tragedy (The Press, 1996 and 1999; The Southland Times, 1999). Other health topics reported on local outbreaks of infectious diseases (The Southland Times, 1994 and The New Zealand Herald, 1997). The Cave Creek accident (The Southland Times, 1995) and a missing student (The Evening Post, 1999) were also local main page news items. Sexual health was the concern of two South Island papers, The Otago Daily Times (1994) and The Southland Times (1994).

\section{Achievement}

The Otago Daily Times (6) and The New Zealand Herald (5) provided the majority of 14 story subcontents in this category. The Press had no publications at all in this subcontent. All seven articles were local in origin and focused on student achievements. The Southland Times (1990), The Evening Post (1989) and The Otago Daily Times (1995 and 1996) reported on scholarship and academic achievements. Another publication in The Otago Daily Times (1998) featured an article by an expert commentator. This article discussed the need for high expectations if children are to succeed at school. However, there was a cautionary letter to the editor in The New Zealand Herald (1997) pointing out that examination league table results were no indication of quality education within a school. A view also shared by a secondary school principal's expert opinion published in the same newspaper a few days earlier (1997). Finally, there was one contribution from The Otago Daily Times (1995) that focused on sporting achievement. 
Innovation and career achievements, through education, were also reported particularly in The New Zealand Herald (1996, 1998), The Otago Daily Times (1990, 1996) and The Southland Times (1999). There was one article on ethnic minority exam achievement published as a feature in The New Zealand Herald (1993).

\section{Student Funding}

In this subcontent a North Island-South Island difference was found with The New Zealand Herald providing five of the ten student funding publications. The New Zealand Herald reported on; the proposed student loans (1989), how students could use their vote in the general election to protest against the student fees (1990), The Todd Report advising student fees to increase (1995), and the subsequent result in deterring students from enrolling at university (1996). However, this was not the first time students had been cautious about enrolling for tertiary courses. The New Zealand Herald (15 February, 1989) had reported that students were "wary of taking Forestry courses” because of the expense and with no guarantee of employment once they had completed the course. The Evening Post's (12 December, 1998) only article was a letter saying that life "was no harder on the dole" compared with those living on a student allowance. The Press (1992) published an article written by an expert about the student allowance triangle. The article warned of the huge amounts of debt the students were running up, and pointed out there was no legal obligation for students to inform their parents about it.

The second contribution from The Press (1995) was a feature article focusing on the possible exploitation of immigrant students who came to New Zealand to learn English. The Southland Times sole contribution reported on a student prosecution for benefit fraud while receiving the student allowance (1991).

\section{Protest and Conflict}

A possible North Island-South Island variation was also found in this subcontent with the South Island papers contributing seven of the nine publications in this category. A division was also found between the earlier internationally sourced articles published between 1989 and 1991 and the later 
local, and nationally sourced, publications concerning events within New Zealand.

During the earlier period there were five international main page news stories concerning overseas student protesters. The Southland Times published three articles about Chinese student protesters in 1989, while The Press published an article concerning Korean students’ protests (1991). The Otago Daily Times (23 May, 1989) also published an internationally sourced article warning students against “protest exploitation”.

The locally based articles concerning protest and conflict were varied in kind. The Evening Post (1993) published a letter objecting to students being failed for questioning the teacher, while The Press (3 August, 1993) reported that the "Nurse culture may alter", which was in response to a student nurse's objection to the cultural safety component in the nursing curriculum. The New Zealand Herald (1995) reported on a group of students invading the Ministry of Education's office in protest to the increase in student fees. The Otago Daily Times (1996) published an article where a parent had advocated students to protest in response to the tertiary fees increase and the Government's underfunding.

\section{Discipline}

The South Island papers provided five of the seven articles concerning discipline, with The Otago Daily Times publishing three of the articles. Two articles in The Otago Daily Times (1992) concerned university students' unruly behaviour. The third article, published in 1994, reported on student vandalism of a polystyrene guerilla and rhinoceros. The remaining two articles from The South Island reported on the problems faced by a school after a court decision on its alcohol imbibing male students (The Southland Times, 1990), and in The Press (1995) concern was expressed about the high numbers of school suspensions; a topic that was also shared by The New Zealand Herald (1997). The Evening Post's (1993) contribution, a letter to the editor, suggested that unruly children were the price of liberalism. 


\section{Miscellaneous}

The 11 articles were evenly distributed across the four newspapers. With the exception of two national articles in The Southland Times (1995 and 1997), all were from local sources. The Otago Daily Times had two publications about university life, one reported over the battle for the position as president of the University's union (1989), the other focused on fire stricken students expressing "delight by public support" (3 September, 1994). The third article, from The Evening Post (1996), published a feature item highlighting university life away from home.

The Otago Daily Times (1996) and The New Zealand Herald (1998) reported on Christmas school plays, while The Southland Times (1998) focused on a primary schools’ choral festival.

Commercial enterprise and extracurricular activity looked at the contributions students made to the local economy, Dunedin's in particular (The Southland Times, 1997), to knitting peggy squares for children in Bosnia (The New Zealand Herald, 1993) and within the school itself (The Evening Post, 1993).

The last two entries in this subcontent reported on computer learning. The New Zealand Herald (1989) discussed the power of computer learning, while The Southland Times (1995) published an expert's comments about the possibility of learning at home via the computer.

\subsubsection{Story Content: Administration}

Within the 46 articles in the administration story content five story subcontents were found. The three main subcontent topics were reforms (13), funding (12) and policy (12); the remaining two subcontents were, curriculum and assessment (5) and role and function (4). The reform articles were published between 1988-1990 and the focus was largely on the Picot reforms. The Otago Daily Times was the exception since it did not have an article on The Picot Report or reforms but reported on The Hawke Report. Later, The Press and The Otago Daily Times were the only two to report on The Government's Green paper (1997) concerning the 'selling of education' at the tertiary level. 
The New Zealand Herald published the most articles on policy. In this subcontent there was no one theme underlying all publications. The South Island contributed nine of the 12 articles on funding, while The New Zealand Herald contributed the other three with two of the articles about bulk funding. The articles relating to curriculum and assessment came from only two newspapers, The Evening Post and The Press but they had no shared common theme. In the last story subcontent, role and function, The Evening Post and The Southland Times shared stories about boards of trustees.

\section{Reforms}

Most of the articles about the education reforms were published over a twoyear period between 1988-1990. During this time The Picot Report and reforms received the most attention with nine articles spread evenly across four papers, although there were no publications found in The Otago Daily Times concerning these reforms. However, The Otago Daily Times published the only two South Island articles found on The Hawke Report. Later, in 1997, two of the South Island papers, The Press (28 October, 1997) and The Otago Daily Times (10 November, 1997) published articles concerning the proposals advocated in the Government's Green Paper on tertiary education. The paper recommended that tertiary institutions should be more efficient by becoming more competitive. In turn, this would produce graduates who would meet New Zealand's economic needs, increase New Zealand's international competitiveness, and it would be more in line with the new public management policies of the 'new right'.

\section{Policy}

Administration policy articles (12) were mainly published between 1994-1999, although The New Zealand Herald had two earlier publications in 1988 and 1990. In the latter period the subcontents were fairly evenly dispersed across all newspapers. However, the subcontents were variable in topics. Two articles focused on the privatisation of the education system (The New Zealand Herald, 1990 and The Evening Post, 1995). Four publications reported on politicians and the influences they had, not only on educational policy (The New Zealand Herald, 1999 and The Evening Post, 1999) but also, on capturing the public's 
vote at the general elections (The Otago Daily Times, 1994 and The Press, 1996). Other articles were related directly to schools, for example, The New Zealand Herald (1988) published a feature article critical of the Government's decision to reduce the unemployment figures by raising the school leaving age. It asked the question if using unemployment figures was a "A crude cure for a sick economy?” (The New Zealand Herald, 22 October, 1988).

Objections were also raised over the Government's intention to introduce a student loan scheme. The Southland Times (1989) featured a report from an international source pointing out the battles that the scheme had caused when being introduced into Britain. The Southland Times (12 May, 1994) also published comments written by an expert about "Secondary schools being dubious about the four term year."

Other objections were also published. For example, The New Zealand Herald (1996) reported over the closure of Nga Tapuwae College ordered by the Prime Minister, Mr. Lange, resulting in the occupation of the building by Maori protesters. Access and the role of schools also appeared in two other publications. The New Zealand Herald (11 December, 1996) published an expert's comment suggesting that "Middle schools [were] a viable educational alternative.” An editorial in The Otago Daily Times (1999) pointed out the difficulties in gaining entry to a school of choice under the Government's new enrolment scheme.

\section{Funding}

The Otago Daily Times provided six of the 12 articles in the funding subcontent and were concerned mainly with tertiary funding between 19891993. The Southland Times contributed two articles, one concerning the userpays funding of education (1990); the other, written by a secondary school teacher, gave his expert comment on using vouchers as a method of funding education (1996). The Press (1991) was also concerned with tertiary fees. The three South Island papers contributed nine of the 12 articles on funding. The New Zealand Herald provided the other three articles, one concerned tertiary fees (1996), and the second and third contributions (one an editorial, the other 
a feature) reported on bulk funding (1997). Not surprisingly, all of the articles concerned with funding were critical of the Government's funding policies.

\section{Curriculum and Assessment}

This story subcontent had five publications with two each from The Evening Post and The Press. The remaining article was from The New Zealand Herald. The Evening Post (1989) published a feature article anxious about the possibility of the National spokesman on Education, Lockwood Smith, taking control of education. The Evening Post's (1999) second article, also a feature, was critical of unit standards. The writer described the introduction of unit standards as being, a "Rotten face-saver for Education botchups" (24 November, 1999). Two academic lecturers from Canterbury University also expressed negative views concerning the changes in the curriculum and assessment methods. One comment saw the proposed 'seamless education' as being flawed (The Press, 1993). The second article, also published in The Press (1992), focused on the threat to the academic role of the university now that the NZQA had given permission for an Auckland based management school to use the title of 'university'. The last publication in this section was a feature, written in The New Zealand Herald (1998), giving positive affirmation of ERO reviews now being welcomed in schools.

\section{Role and Function}

In this last administration story subsection four articles were found. Two concerned boards of trustees. The Southland Times (1995) encouraged the public to put themselves forward for the upcoming board of trustee elections, while the second publication was a letter in The Evening Post (1997) critical about a recent meeting with the board of trustees. The Southland Times (1997) also focused on the need for an educated workforce in Southland to enhance the economic wellbeing of the area. The fourth and only nationally sourced publication in this subcontent concerned the President of the PPTA, Martin Cooney, who vowed “to fight over [his] sacking” (The Press, 3 November, 1998). 


\subsubsection{Story Contents: Institution}

Within the 41 Institution story content articles there were nine story subcontents. The main subcontent was funding (10). Thereafter, the story subcontents steadily decreased in the number of publications beginning with health and safety (6) and ending with building (2) and alternative education (2). The South Island newspapers published more articles in funding, health and safety issues, access, protest and conflict, role and management and building subcontents. The Otago Daily Times provided all four articles on socials and ceremonies. Closures were predominantly from The New Zealand Herald, and the same articles provided the only two letters in this section.

\section{Funding}

The ten publications concerning funding were local responses to the Government's funding policies and to the education reforms that is, the increasing Government underfunding, cutbacks and increasing privatisation of education. The South Island newspapers contributed the most publications with eight articles. Four articles were concerned about university funding. The Evening Post's (1988) feature article discussed the funding pressures, while The Otago Daily Times (29 June, 1988) went so far as to describe the university funding to be in 'crisis'. Two years later The Otago Daily Times (14 December, 1990) reported that the Vice-Chancellor was warning that, "Otago university would need to reduce its administrative costs [and that] the university will restrict entry” because of Government cuts and underfunding.

The early childhood education sector had three publications concerning funding cuts. The Southland Times (1992) reported on kindergartens being under funding pressure, while The Otago Daily Times (1994) reported on children fund raising for their local kindergarten and The Evening Post (1996) published the opinion of the national secretary of NZEI about the 'new right' ideology undermining kindergartens.

Not all articles were accepting of education institutions being underfunded. A feature article in The Press (18 May, 1993) asked, “Do tax payers believe they get value for their money?” In an earlier Press editorial (1990) there was 
considerable discussion on the Government's funding going to independent schools and their right to have such funding. Lastly, The Press (23 July, 1996), in a feature article written by David Lange, outlined “How Education's touchy-feeliness lets the Treasury win everytime” when it comes to funding.

\section{Health and Safety}

The Press (1993; 1994; 1997) and The Southland Times (1993) published four of the six articles concerning health and safety issues. The other two articles came from The New Zealand Herald (1990; 1999). The Press (1994; 1997) and The New Zealand Herald (1999) published three articles focused on the health and safety of those in unsafe or poorly maintained buildings. However, there was a different safety issue, that of safe management practices, which led to The Press (1993) raising the issue of an inquiry into early childhood care (Peter Ellis inquiry) and The Southland Times (1993) looked at the bicultural safety in schools. Five of the articles were local; The New Zealand Herald (26 June, 1990) published the only international article, this concerned well-known English public schools allowing their students “To go to pot”.

\section{Access}

The Press provided four of the five articles concerning access to institutions. Two focused on zoning (an expert comment in The Press, 1991) and enrolment schemes (an editorial in The Press, 1995), one reported on students being banned from playing sport (The Press, 1997) and the fourth article concerned an open day at the local polytechnic (The Press, 1998). The Southland Times (1992) wrote a feature article on the tokenism displayed toward minority staff appointments that still existed in many institutions. There were no North Island publications.

\section{Protest and Conflict}

The Press (2), The Otago Daily Times (2) and The New Zealand Herald (1) were the only three newspapers to have articles in this subcontent. The Press (1995) published two articles concerning the role of New Zealand universities in relation to the New Zealand Qualifications Authority. Both articles were comments by experts. The Otago Daily Times had different concerns. In 1994 
the paper reported on student protest in response to the school management cancelling a social function. The later publication, in 1996, reported on a meeting between university management and students to try to resolve the discontent arising from the university's managerial decisions. The New Zealand Herald's only article (1995) reported that the Prime Minister, Mr. Bolger, backed a decision to remove Maori occupying Tamaki Girls College in protest to that school's closure.

\section{Role and Management}

The four articles in this subcontent were published over a period of three years from 1994-1997. Three of the four publications came from the South Island. The Press supplied two (1994; 1996), the other was from The Otago Daily Times (1997). The fourth article came from The Evening Post (1995). Considerable variation was found among the topics. A feature article in The Press (1994) questioned the role of intermediate schools. The Evening Post (1995) featured an article about a local primary school winning praise from ERO. Ownership of universities was raised in a feature publication in The Press (1996) while The Otago Daily Times (1997) highlighted the wider economic effect the Otago University had within the local community.

\section{Socials and Ceremonies}

The Otago Daily Times published all four articles in this section. Two were published in 1991, one was a feature article that reported on an early childhood centre opening, the other on a university capping ceremony. The other two articles were published in 1993; one focused on a school gala, while the other concerned a school reunion.

\section{Closures}

The New Zealand Herald supplied two of the three articles concerning closures, both were letters to the editor and both published in 1996. One letter discussed the effect the school closures had on road traffic during the school holidays. The other letter was concerned about the possible closure of a boarding school and the disadvantage that would create for out of town girls to their education. The other closure, published in The Press (1995), related to 
The America's Cup trophy being paraded through the Christchurch streets and that schools had closed for the special occasion.

\section{Building}

Both articles came from South Island newspapers, The Southland Times (1991) and The Otago Daily Times (1996). Both concerned fires that had destroyed schools, both were main page newstypes and both were from local sources.

\section{Alternative Education}

This last subcontent in the institution story content section focused on education outside mainstream schooling. The Evening Post's (1988) local feature article reported on home schooling, while The Southland Times' (1998) local feature article focused on the Rudolph Steiner philosophy of education.

\subsubsection{Story Content: Staff}

There were 26 Staff story contents and eight story subcontents: conflicts (7), performance and assessment (4), teaching role (4), employment (4), health and safety (2), obituaries and retirements (2), salaries (2) and, achievement (1). Some of the story subcontents, for example, salaries, resignations, performance and assessment shared similar themes but had sufficient story content to be independent of the other subcontents. A pervading discontent was found in subcontents relating to salaries and employment conditions. Furthermore, there was little positive reporting, other than two articles published in The Southland Times during 1999.

\section{Conflicts}

Staff conflict was the most frequently published subcontent with seven articles and all were from local sources. Five story subcontents related to disputes or strikes over salaries in all newspapers except The Press, which had no publications in this area. Specifically, The Southland Times (25 March, 1989) featured an article titled, "When teachers are away most pupils play" pointing out that even though provision was made for pupils to attend class while teachers were on strike, most pupils chose not to go to school. Another two articles discussed pay parity between primary and intermediate teachers' 
salaries compared to their colleagues' salaries in secondary schools. The Southland Times published a feature written by an expert in The Southland Times (28 July, 1994) recognising that, "Shoe size has nothing to do with teachers' salaries." The second article, this time published in The New Zealand Herald (1995), discussed the national strike planned by primary and intermediate school teachers for pay parity. The Evening Post (1994), in a feature article written by an expert, discussed the role of mediation to reduce dispute costs.

Pay parity was not the only pay issue with teachers. Redundancy and resignation issues were also of concern. The Evening Post (8 September, 1989) published an article about the staff from The Central Institute of Technology demanding a "fairer redundancy deal", while The New Zealand Herald (14 April, 1994) described the resignation of the principal of a private secondary school as being, "the end of term." This principal had been in conflict with the school management and so had chosen to leave. A later article in The Otago Daily Times (13 January, 1998) described, “the realities of primary teaching prompt career changes.” This feature article, written by an expert, discussed the factors, for example, heavy workloads and low pay, contributing to teachers leaving.

\section{Performance and Assessment}

These four publications reported on teachers' performances and assessment with The Evening Post publishing three of the four articles. Two of the three articles in The Evening Post were comments by the same expert on assessing staff. One focused on assessing academic staff (1994), while the other comment focused on teacher assessment (1995). The Evening Post's (1999) third article, a feature, reported on teacher performance, while a letter in The New Zealand Herald (6 January, 1997) wrote, "just blame it all on that despicable lot - the teachers" for the appalling state of spelling. This was a tongue in cheek letter and went on to point out the problems of teaching large class sizes. But, pervading most of these articles was the belief that teachers' salaries should be closely linked with performance. 


\section{Teaching Role}

Three of the articles in this subcontent came from North Island newspapers. The Evening Post published two articles and The New Zealand Herald, one. The Evening Post (1990) published a letter discussing the role of the teacher. A similar theme was found in another letter, this time in The New Zealand Herald (1997). The second publication in The Evening Post (1992) was a feature article querying the control held by teachers' and was firmly of the opinion that control often found its way into the wrong hands. All three North Island articles were negative toward teachers. However, the fourth publication in this subcontent was more positive. The Southland Times (1999) published a feature about music teaching being an 'honourable craft'.

\section{Employment}

Three of the four employment story subcontent articles were published in The New Zealand Herald. Two of the publications described university-teaching appointments (1989, 1997). The Herald's third article, published in 1999, was a letter that discussed the flaw in recruiting teachers from overseas to redress the teacher shortage. A similar view was written in a letter to The Otago Daily Times of the same year. This letter expressed disillusionment and frustration in applying for a teaching position but had been turned down, yet at the same time there was a concerted effort to recruit overseas teachers. The writer queried the necessity for such a campaign when New Zealand already had well-qualified, experienced and willing New Zealand teachers available.

\section{Health and Safety}

In this subcontent there were two publications. The Evening Post's (1991) article concerned a school sports coach who had been attacked and injured during a game. This had led to his resignation. The second article published in The Press (1997) considered the Peter Ellis Inquiry into child abuse the equivalent of a witch trial. 


\section{Obituary and Retirements}

Both articles were published in The Otago Daily Times (1992; 1997)). The earlier article featured an obituary on the life of Karl Popper, the philosopher. The second publication discussed the retirement of a local music teacher.

\section{Salaries}

Both articles were North Island publications. The New Zealand Herald (1991) reported in a locally sourced publication that the teachers' unions would not be seeking a pay rise while The Evening Post's (3 May, 1999) feature article raised the question, “Are teachers getting precious?” in reference to their salary and employment expectations.

\section{Praise}

This solitary article came from The Southland Times (1993) when the Rector from Southland Boys High School, during a student prize giving, acknowledged the work teachers did and asked for the community to support the teachers' work.

\subsubsection{Story Content: Finance}

The Finance story content had 16 story contents, which were divided between two story subcontents, Government cuts and underfunding (9) and equity distribution and management (7).

\section{Government Cuts and Underfunding}

Concern was expressed from all educational sector levels about the Government's underfunding and cuts from 1989 onward. However, the South Island papers focused solely on the effect that the underfunding and funding cuts had on the tertiary sector. The Press published three articles on the topic (1993 and two in 1995). The 1995 publications focused on the need for a fee increase resulting from the Government's actions, and the need to attract overseas fee paying students, to offset costs. The Otago Daily Times (1995) also published an article discussing what the implications were for its local university, while The Southland Times (1996) featured an article about the effect the funding cuts would have on their local polytechnic. 
The Evening Post had three publications and all were letters to the editor. Two letters written in the same year (1989) came from the same contributor, A.C. Scott. One letter supported the teachers saying that, "teachers were not grandstanding over funding” (The Evening Post, 8 September, 1989). The writer's second letter believed that the extra funding from the Government would not go to schools because under Tomorrow's Schools the administrative costs to school boards were "relatively costly and inefficient" (The Evening Post, 4 October, 1989). The third letter in The Evening Post (1994) came from J. MacCormack, President of Victoria University Students Association, critical of the Government's choosing to underfund tertiary education. The New Zealand Herald's only article (1998) discussed the difficulty of staff retention with school principals digging into their own pockets to cover costs.

\section{Equity, Distribution and Management}

The North Island newspapers had five publications in this subcontent while the other two articles came from The Otago Daily Times (1991; 1993). A letter to the editor in The New Zealand Herald (1995) thought private schools should not receive Government funding because it was iniquitous. A later feature article in the same paper (1997) argued for more funding to schools because of the high cost of living in Auckland. The New Zealand Herald's third publication (2 September, 1998) was from an expert who thought, "the self management of schools was not the answer" when it came to managing school funding. Another expert comment, this time in The Evening Post (1996), took a philosophical look at market theory in relation to education. The other publication in The Evening Post (1992) was a letter concerned with bulk funding. The remaining two articles in this section were from The Otago Daily Times. The first publication, in 1991, discussed the distribution of a capital works grant where the 'Lions share' went to five schools, while the second publication in 1993 was hoping the university could have found extra funds to have supported a fellowship. 


\subsubsection{Story Content: Curriculum}

Thirteen articles with a Budd score of four were found in this category and could be put into two subcontents, curriculum and assessment and, reports with nine and four articles respectively.

\section{Curriculum and Assessment (New Curriculum framework)}

Publications on this topic were largely concentrated within two years, 1995 and 1997. The New Zealand Herald, The Evening Post and The Southland Times each published a local feature article about the new English curriculum. However, The Evening Post's (1995) publication was critical of reading standards in general, while The Southland Times (1995) was critical of the English standards derived from an ever increasing centralisation of education under the new curriculum framework. This article went so far as to ask the question, "Is New Zealand educating for democracy or a dumbocracy?” ( The Southland Times, 21 June, 1995). An earlier publication in The New Zealand Herald (5 October, 1991) had outlined the need for a curriculum change by reporting, "How Marx had got it all wrong” and how the current curriculum was failing the students by being non-competitive.

There was another response in 1997 to the new social studies curriculum. This time the two feature articles were from the North Island papers with a contribution each. Both publications were critical of the latest proposals. Later, The Press (1999) published an article critical of NCEA organisation. In keeping with the social studies theme, The New Zealand Herald (1997) also published an article about cultural safety at the tertiary level. The curriculum content was being revised after a third year nursing student at a Christchurch polytechnic had protested about the cultural safety within the course content. The only positive publication about the new curriculum came from The Southland Times (1998) which welcomed a new sports course which was expected to provide career and employment opportunities for their school leavers. 


\section{Reports}

The New Zealand Herald and The Evening Post published two and one articles respectively of the four articles in this category. The New Zealand Herald's (12 July, 1988) publication on The Black Report outlined what parents wanted from the education system - parents wanted 'their children's' minds to be stretched." The New Zealand Herald's later report, in 1994, came from The Education Forum. This report was more explicit on where the education/curriculum should be focused and that was on vocational skills. The Evening Post's (1994) sole contribution was a letter pointing out the value of School Certificate and querying the need to introduce a new form of assessment. The fourth report, a feature article published in The Press, concerned Alton-Lee's Report (1992) that had found inequalities of gender and race.

\subsubsection{Miscellaneous}

This section briefly discusses the remaining six story contents, commercial enterprise (6), institution buildings (4), Maori education (3), education Purpose (2) and general (2).

\section{Commercial Enterprise}

The commercial enterprise stories covered topics that predominantly looked at how schools could, or had, become businesses. Most of these articles came from South Island papers. The Press published two articles in this category. The first publication, in 1990, was an editorial recognising the 'commodification' of education with New Zealand's education system now having overseas fee-paying students. A second article, with the title, "Myers blasts education muddle" was from the Chairman of the Business Roundtable extolling the virtues of running the education system on a business model (The Press, 20 May, 1996). The other two South Island contributions came from The Otago Daily Times. The first, a feature article (1993), reported on a school science competition sponsored by a national business corporation, while the second article promoted Dunedin as being, "the City of Learning” (28 October, 1997). The last contribution came from The New Zealand Herald (1999). This news item, written by an expert, highlighted how tertiary research had become 
big business. The sixth contribution in this story content category has been acknowledged earlier in the student story content (The Evening Post, 1993).

\section{Institution Buildings}

In this section The North Island published three of the four articles. The topics varied widely. The New Zealand Herald had two publications, one on heating cold classrooms (1992), the other reported on staff and student protests about the removal of classrooms considered by The Ministry of Education surplus to requirements (1998). A letter to the editor in The Evening Post (1992) wrote about fire prevention in schools while the fourth publication, in The Otago Daily Times (1989), reported that joint tenders had been approved for building a student centre at Otago Polytechnic.

\section{Maori Education}

The New Zealand Herald wrote two articles with respect to Maori education. The first, published in 1988, reported on the negative response secondary school teachers had had to the suggestion made by the Maori secondary school teachers' group that the Maori language be compulsory in schools. The New Zealand Herald's (1998) second article had a more positive report. Beverley Manahi (also written as Manihi), Principal of Haoni Waititi Kura Kaupapa, wrote that, "Maori had been quietly developing their own alternatives" (The New Zealand Herald, 1 September, 1998) since Tomorrow's schools had been introduced. Another article, this time in The Press (29 January, 1992), also gave a positive report when it described the opening of a "School of Hope" for underachieving Maori students.

\section{Education Purpose}

There were two publications from the North Island concerned about the purpose of education. One was an expert comment who advocated a less rigid learning environment (The New Zealand Herald, 1995). The second, a feature article, discussed the role of teaching moral values (The Evening Post, 1996). 


\section{General}

The two contributions in this section came from the South Island. One article advised the public to stay away from school reunions because they "produced melancholia” (The Southland Times, 11 December, 1996); the other article (the only contribution from a student with a Budd score four) discussed the need for partnership, rather than leadership, within the community for its survival (The Otago Daily Times, 1999).

\subsubsection{Summary of the Analyses and Results from Budd Score Four}

In keeping with lower Budd scores, the Student story content was found to be the main category with 66 publications representing 29.3\% of all articles with a Budd score of four. The second story content was administration with 46 articles. This story content's position differed to the lower Budd scores where the institution story content held second place. In this chapter however, the institution story content was third with 41 publications. All other Budd score four story contents held similar positions to those held in the lower Budd score categories.

Interestingly, while all newspaper articles could fit readily into the story content and subcontent categories, variations within these categories were found between the North and South Islands for example, student protest, discipline, and funding, or the staff teaching role. The newspapers were, however, generally critical of Government policies on funding, or the lack of funding, and cuts. The Southland Times could be described as the most positive in reporting articles particularly in relation to the teachers' role, new sports curriculum and ERO reports, although the latter subcontent was also shared with The Evening Post and The New Zealand Herald.

There were three stories directly related to Maori education and another two articles focused on Maori protests. The protests concerned the closures of Tamaki Girls College and Nga Tapuwai Community College. 
In many of the story contents and subcontents, the underlying pervading themes were health, safety, funding, protest, conflict and economic links with the wider community.

\subsection{Introduction of Budd Score Five Results}

This section presents analyses of the findings in the five major daily newspapers surveyed that had a Budd score of five during the 1988-1999 period. The primary focus is on the story content and story subcontent, but where relevant newstype and locality will be discussed. The results of the findings are presented in Appendices, Tables A.7:13. and A.7: 14. This chapter will present the analyses of the results as follows:

- Overview of Budd score five results

- Analyses of Budd score five results

A summary of the Budd score five results and analyses will conclude this chapter.

\subsubsection{Overview of Budd Score Five Results}

As discussed earlier (chapter five), articles with a Budd score of five were considered to be the most significant and important compared with other articles published within the same newspaper. The number of articles concerning education found in this survey were 31 , which represented $0.5 \%$ of the combined total Budd score count (chapter six). Not only were there considerably fewer publications, but there were also fewer story content categories (6). The most frequent story content published with a Budd score of five was the student category with 16 articles. This contributed $51 \%$ of all publications in this score range. Administration and institution followed with six and five publications respectively. The remaining three story content categories were commercial enterprise (2), curriculum (1) and general (1).

\subsubsection{Newstype and Locality}

The newstype was predominantly feature articles (23) which represented $74.2 \%$ of publications within this Budd score range. News (5) and main page news (3) followed. There were two pupil/student contributions and one 
contribution each from an editorial and expert comment. Except for one international and one national article all other sources were local in origin.

\subsubsection{Story Content: Student}

As noted, this was the most frequently published story content within the Budd score five range. Within this story content there were four story subcontents. student achievement had the most articles with six publications. This was followed by health (4) and learning activities (2). Finally, there was a miscellany of four items.

\section{Achievement}

In this section five of the articles came from South Island newspapers. The Otago Daily Times (1992;1999) focused on university exam and capping achievements. The Press (1989) also focused on university exam results. The second contribution from The Press (9 December, 1991) reported on a group of secondary school pupils' academic achievements in which it described the pupils as being "In a class of their own." The third article focused on the academic achievement of a secondary school student which described him as being, “An outstanding student” (The Press, 7 December, 1999). The Evening Post (1994) provided the sixth and last contribution in this section. This paper's focus was on a sports achievement - a dragon boat race in which Chinese scholars had participated.

\section{Health}

The North Island newspapers provided three of the four news items in this subcontent. The New Zealand Herald (1990) published the only international article with a Budd score of five. This article focused on American children having a high dropout rate from school because of their alcohol problems. The Evening Post published two articles. One featured "Kids on dope" (The Evening Post, 22 November, 1997) and the deleterious effect it had on their lives. The other feature article had the headline, “Our little secret”(The Evening Post, 16 October, 1999). This reported on a child sexual abuse case where the offender had been the child's teacher and the subsequent ongoing effects that it had had on the victim 20 years later. 


\section{Learning Activities}

These two feature articles came from the South Island newspapers. The first publication came from The Otago Daily Times (1988) and featured a resource page for primary pupils. The second news article was from The Press (1992) and featured a group of primary pupils visiting its newsroom. Not surprisingly, the headline read “A day with The Press” (The Press, 24 February, 1992).

\section{Miscellaneous}

All four contributions came from South Island newspapers and all four were feature publications. Two articles were contributions from pupil/students. The first pupil contribution came from students who were leaving primary school to enter secondary school the following year. Their headline read, "Thank you for the best years of my life" (The Southland Times, 22 October, 1988). The second pupil contribution, this time published in The Otago Daily Times (29 October, 1999) noted that "young voters were not bothered by the [General] election.” The need to protest, through the ballot box, against Government tertiary funding policies did not bother them. An earlier publication from The Otago Daily Times (27 June, 1999) featured an article about "Savouring the Scarfie lifestyle.” This reported on the benefits of attending Otago University. The final publication in this section featured an article in The Southland Times (1998) concerning the closure of Kingswell High School. There had been several low Budd scoring articles published over many months in this newspaper tracking the likelihood of this school's closure. The final article reporting on the college's closure had a Budd score of five and published a headline that read, “Kingswell High School 1971-1999” (The Southland Times, 12 December, 1998).

\subsubsection{Story Content: Administration}

This second most frequent story publication in this Budd score range has only six articles and all were published between 1988-1994. Within this story content are two subcontents only, The Picot Report and reforms and, The Hawke Report with five and one articles respectively. 


\section{The Picot Report/Tomorrows Schools}

The only two newspapers concerned specifically about The Picot Report and Tomorrow schools were published in The Evening Post (1988) and The New Zealand Herald (1989). The front page headline in The Evening Post (10 May, 1988) read, "Education shake-up saves $\$ 93$ million. The article gave the main points in the reforms and reported that, "The education system should be radically restructured to give schools more autonomy....” A year later an editorial in The New Zealand Herald (16 May, 1989) described the Picot reforms as, "A Social Advance in its Infancy" because there would now be accountability between home and school. Responses to the Picot reforms were mixed. The Press (1991), in a feature article written by Shona Hearn (President of the New Zealand Post Primary Teachers' Association), was critical of the radical changes that had occurred during the previous few years, and more changes were to come. Hearn predicted there would be an increase in the privatisation of schooling while, at the same time, there would be a corresponding withdrawal of State support. In particular, Hearn foresaw Government funding being reduced through underfunding or by direct cuts. She described the forthcoming changes leading to, “The coming crisis for NZ education” (The Press, 27 March, 1991).

Another article, also published in The Press (11 February, 1994), featured a school principal's opinion where, "School means business." This gave an account of the changes that had occurred within a secondary school where a change of image and improvement of standards had been required to avoid the school being closed. With the removal of zoning this school had had to become competitive. For this principal, the school image was taken very seriously as an important part of attracting, and then keeping, students.

The last article relating to this section was published in The Otago Daily Times (14 July, 1992) giving a full-page news item of the "Unofficial list of School Boards of Trustees around Otago.” 


\section{The Hawke Report}

There was one feature article published in The New Zealand Herald concerning this report. The first publication (1988), a feature from a national source, outlined the proposals including polytechnics increased funding, upskilling of courses and their authority to grant degrees. The accompanying headline described the expected changed role of the universities as, "Varsities marked down from Top Spot” (The New Zealand Herald, 27 September, 1988).

\subsubsection{Story Content: Institution}

There were five articles found in this section which was further divided into two subcontents, academic focus (3) and reunions (2). All articles were features and were from local sources.

\section{Academic Focus}

The Otago Daily Times (13 November, 1991) attributed The Otago Boys High School's outstanding achievement in exam passes due to the, "Academic emphasis at OBHS." The Evening Post (1995) let the public choose their school preference by supplying a list of independent, private and state local primary, intermediate and secondary schools. Accompanying the list was a description of what each school had to offer, its decile and costs. The third news item, this time from The Press (1997), featured an article looking at the costs involved when schools introduced computer technology, but also emphasised how useful the new technology would be in teaching.

\section{Reunions}

Within this subcontent The Otago Daily Times (1988) featured an Otago Boys High School reunion, while in another feature, The Evening Post (1999) reported on Victoria University’s Centennial.

\subsubsection{Commercial Enterprise}

Both these publications came from The Southland Times (1988; 1995). Both were local feature articles and both came from commercial sponsors who provided grants and scholarships to school students. 


\subsubsection{Curriculum}

This sole article, provided by The New Zealand Herald (1988), featured a science fair for school children and emphasised the importance of science in the school curriculum.

\subsubsection{General}

This last publication with a Budd score of five was a feature article published in The Southland Times (1988). The article focused on students who had successfully completed Link courses that year.

\subsection{Summary of the Analyses and Results from Budd Score Five}

The predominant story content with a Budd score of five was the student category, which was in keeping with the predominant story content in the other Budd score ranges. However, the main student story subcontent (achievement) with a Budd score of five differed from the main student story subcontent in the Budd score of four category (health). The second and third story categories, administration and institution, reflected the same positions as those with a Budd score of four.

The Budd score five section is notable for its absences, especially in terms of story content and newstype. There were only 31 articles about education published in the twelve-year period. There were very few articles written about the education reforms. There were two years, 1993 and 1996, when no publications about education at all were found with the highest possible Budd score. Significantly absent were story contents published about finance, staff, Maori education or the purpose of education. Equally significant was the reduction in the number of editorials (1) and complete absence of letters to the editor. 


\section{CHAPTER EIGHT - DISCUSSION: Part One}

\subsection{Introduction}

This chapter and the next will discuss the results of the research. They will focus on the similarities and differences of the results as compared with the academic and professional literature in chapter three.

In all, a total of 136 publications were found with a Budd score of four or five that shared similar themes with the issues highlighted in the literature review in chapter three. A further nine publications related to the Picot Report/Tomorrow's Schools. The remaining 111 unrelated articles with high Budd scores, and the 5,910 articles with Budd scores in the 1-3 range that predominantly concerned student, administration and institution story contents, will not be discussed. Of the 136 publications with a high Budd score 88 articles were concerned with funding issues. Therefore, this chapter will focus on funding topics alone. The remaining significant topics that emerged from the research will be discussed in the next chapter.

\subsection{The Picot Reforms/Tomorrow's Schools 1988-1989}

The main thrust of the educational reforms was to reduce the size of central bureaucracy and to convert each learning institution into a self-managing unit with its own elected board of trustees. Parents and communities were to be consulted and involved. There was to be an emphasis on partnership between the schools, the boards of trustees, parents, students and communities. Access to the Ministry of Education was via the Parents' Advocacy Board and Community Education Forums. The policies were legitimated through the rhetoric of individual freedom, parent power and consumer choice through which universal social goals of equality and democracy would be achieved.

In short, the education reforms were intended to produce a closer match between schooling and economic growth (see. 3.8). 
The driving force behind the educational reforms was the Government's need for economic survival in an ever-increasing highly competitive and technological international market. The argument, borne from the fiscal crisis of the welfare state (see chapter two), led to a policy change based upon neoliberal economic policy and has been referred to as 'new right' ideology (see 2.3).

This change culminated in drastic and dramatic state sector reforms based on the free market claim that it was superior on two fronts. First, advocates of 'new right' theories believed that neo-liberal economic policy was the most efficient way of distributing scarce resources and therefore, was a morally superior form of economy. Second, the anti-state, anti-bureaucracy stance on 'big brother' governments leading to corporatisation and privatisation to limit state intervention was believed to justify it as a morally superior form of political economy. Finally, to support such a structure, there was a corresponding shift to a moral conservatism, which was based on fundamental and individualist values. These values not only supported individualism as described above, but also were seen to be anti-social, anti-feminist and antiMaori (see 2.6). It was in this climate of change that the newspapers reported on the Picot reforms.

Given the momentous implications of this form of economic policy and its impact upon education it is surprising how few newspaper articles with a high Budd score were published. Between 1988-1989, when the major education reforms were introduced and implemented, only nine newspaper articles were found to have were reported on the changes proposed in the Picot Report. The North Island newspapers provided seven articles, while The Press and The Southland Times published only one article each.

Generally, the early articles analysed in this study were positive toward the proposed changes. Wellingtonians were told in The Evening Post (10 May, 1988) that the “education shake up could save $\$ 93$ million” in administration costs. Picot considered "the present administrative system was over-centralised and inefficient, and should be replaced by a simpler structure.” (An earlier 
report in The Evening Post, 22 February, 1988, acknowledged there could be job losses of 5000.) However, this article focused on the savings that could be made and the money could go to schools. It even suggested that "up to 94.5 per cent of the school's budget could be administered by the school.”

A second article in The Evening Post (10 May, 1988) emphasised the advantage that schools would have in deciding on staff levels and the closer relationships between schools and communities. It also suggested that teachers' colleges would become semi-autonomous within universities. A third article, in the same newspaper, stressed the 'opt-out' option for minority groups if their need were not met by 'main stream' institutions. This would ensure "Maori and other minorities are not subordinated to the majority interests.” This is an interesting point in light of Mr Lange's fear of 'Maori capture' arising from an incident in his own electorate (see 2.5). The Picot Report clearly provided for Maori and other minority groups whom, if they felt mainstream education was not meeting their needs, could opt out and establish their own educational institutions.

"Forums could play important role" was the headline to a fourth article in The Evening Post (10 May, 1988). Forums were "to promote debate on educational issues” and would involve people from various levels of education to discuss issues and provide feedback on policy ideas. Furthermore, the article reported \$3 million for funding be set aside for the forums and the intended Parents' Advocacy Council. In short, there was money being set aside for the public to use when contributing to the education debate.

However, despite such incentives, the rapid changes were taking its toll on the public. In response to public pleas to let up, Mr Lange pledged, "to let up on the pace of the reforms" (The New Zealand Herald, 18 March, 1988). Oliver Riddell, parliamentary reporter, however re-emphasised the need for Mr. Lange to implement the changes swiftly if they were to succeed (The Press, 21 May, 1988). Riddell believed successive governments had "backed off" education changes when met with opposition, giving The Currie Committee (1960) and The Nordmeyer Committee's (1970) recommendations as 
examples. Speed, therefore, was of the essence to ensure the success of the reforms.

Riddell thought that the greatest resistance to the changes would be from the primary schools, which had described the changes as "simplistic", because they would be most affected. The secondary teachers' union, the Post-Primary Teachers' Association (PPTA), described the changes as a "New Right takeover." But Riddell thought secondary schools would "cope comfortably" because the new system was not so very different from the existing schools' boards. Riddell concluded that whether or not the system would work would depend on "how tight the charters for schools are and how rigidly they're enforced” (The Press, 21 May, 1988).

Riddell's fear of a back down was not warranted. Although Roger Douglas, the Minister of Finance who had implemented the changes, had resigned in 1987 and the well-known acrimony between Douglas and Lange had reached its zenith during 1988, the reforms were too well established to be retracted. Furthermore, Treasury, Government and Lange, for different reasons, wanted the reforms to continue (see 2.4 and 2.5).

Riddell may have been less optimistic had he known the fate of the school charters, the Parents' Advocacy Council and the Community Forums which rapidly receded from influence as the reforms progressed through into the 1990s.

Newspaper support for the Picot reforms, which by now encompassed the “Tomorrow's Schools” report, continued to be reported in positive terms. “Group support Picot’s nod to self rule”, The Evening Post's (12 July, 1988) headline read when describing the 20,000 submissions on the proposed changes. However, buried within the article were concerns from The Department of Education and the primary teachers' union, the New Zealand Educational Institute (NZEI), about the burden placed on inexperienced parents, the destruction of national procedures on appointing teachers, loss of 
advisory services and the difficulties in maintaining the national character and quality of curriculum.

The secondary schools' union, the Post-Primary Teachers’ Association (PPTA) was in favour of community involvement but wanted to get the "balance right". The PPTA also feared that the report "overcompensated towards devolution, which could lead to greater centralisation.” Interestingly, the article did not elaborate on the PPTA's contradictory statement. Based on educational ideology and practice, the PPTA understood that many of the 'new right' ideologies would directly conflict with educational ideology. This was because both sides held very different assumptions about human nature, the role of society, the role of the state and the role of education (see 3.5.1).

Second, while academic and professional writers had discussed the paradox of decentralisation (see 3.7.2), newspapers tended to ignore such a concern. An explanation for ignoring the PPTA's comments may relate to 'provider capture' (Bertram cited in Olssen and Matthews: 1997:14; see 2.4). The newspaper article was focused on the new role that parents and the community were expected to play. Provider capture had been one of the reasons why Treasury wanted to introduce new public management policies. By ignoring the PPTA's comments the article has sidelined and reduced both professional opinion and provider capture.

The human capital cost of restructuring came early in 1989 when employees from Education Boards were being made redundant and were replaced with newly formed administration services. The New Zealand Herald (1 February, 1989) featured such a change. While some former employees from the old boards found re-employment in the newer services, others did not. For those who joined the newer 'one-stop-shop' services, it was also a change in the philosophy of employment. These newer services were established on 'market ethos' and were expected to compete against private services for work in the education sector. 
Further upheaval was revealed in a letter to the editor of The Southland Times (7 April, 1989) submitted by “Gran”. Gran’s letter illustrated the difficulty a community was having in trying to implement the reforms with a lack of information. Gran's letter was specifically concerned with 'how to' incorporate the Treaty of Waitangi's principles into the local school charter. The district senior inspector, Mr. M.B. Harrington, provided some guidelines suggesting the school charter "respect the dignity, rights and individuality of each student.” This included Maori culture and language. His suggestions were very vague and lacked any concrete guidelines of real help. Whether or not Gran and her community resolved the problems, along with the uncertainty and anxiety of doing the right thing, was not recorded.

The last significant report in this period was an editorial in The New Zealand Herald (16 May, 1989) which was concerned about pre-school education. The editorial focused on the National Party's “enthusiasms for a pre-school education scheme developed in America state of Missouri.” The scheme taught parents to develop their children's intellectual abilities. The editorial thought parents should accept responsibility [blame] for the education of their children. "More generous welfare benefits or state provided day care" were not seen as the answer. Instead, the editorial suggested a "Corp of family advisers" be established. The editorial is quite clear where the intersection between state and parent [private] roles lay. A body of "advisers" would ensure parents met their responsibilities.

This editorial highlights a new tension that emerged from the neo-liberal ideology. Parents were now 'responsible' for their children, yet the editorial saw fit to comment, and provide the solution, in the way of 'advisers' to ensure compliance of an unspecified and unauthorised standard of care. Such a stance from the editorial raises questions of parental choice, whose standards were the parents expected to conform to and who would be their new 'advisers'? Parents were now expected to provide, irrespective of their resources, a 'standard of care' based on what could be described as a very 'critical parent' editorial attitude. The State welfare 'big-brother' had been replaced by a selfappointed privately owned corporate 'big-brother', that clearly reflected the 
'new right' policies. In addition, the article saw itself as fulfilling the newspaper's role of 'watch-dog'.

The tone of the newspapers changed rapidly during the 1988-1989 period. Initially, newspapers supported the education reforms by highlighting favourably the benefits to the public in terms of, choice, control, financial gain, partnership, involvement, more egalitarian and democratic access. Although there were some misgivings, particularly from teachers, these were largely glossed over in favour of the benefits. However, by May 1989 the tone of newspapers had changed as reflected in the editorial of The New Zealand Herald, 16 May, 1989. Parents were now told quite clearly they were 'responsible' for their children, and advisers should be appointed to ensure parents meet their responsibilities, or were they now 'obligations'?

Ramsay (1993; see 3.7.2) has identified two conflicting agendas between educators and parents who sought a partnership approach in the interests of fostering equality on the one hand and, while on the other hand, Treasury and business people wanted choice, competition and privatisation. Up until 1990, Barrington (1998; see 3.7.2) believed that the partnership agenda prevailed, but thereafter, when the National Party came to power, the market agenda flourished.

Editorials are of particular importance because they aim to write to the ' $A$ ' reader audience, that is, the 10 per cent of people who have the most influence in society (Zavos, 2001; see 4.5.1). So to whom was the above editorial addressing? Presumably, not only the parents but also, the ' $A$ ' audience with the most influence. The ' $\mathrm{A}$ ' reader audience included the owner of The New Zealand Herald, O’Reilly, who was recognised as 'no left winger' (Kelsey, 1999; see 4.2.3). It was clear, from the above editorial that the new market ideology by mid-1989 was already overtly in print, two years before the National Government came to power.

It is worth noting that the academic literature, both overseas (Bowers, 1988; Kim, 1989; see 4.6) and in New Zealand (Codd, 1990; Grace cited in Codd, 
1990a; and Barrington, 1990; see 4.6), found that the media tended to support the neo-liberal policies of the government. The editorial in The New Zealand Herald (16 May, 1989) graphically supports their research. It was in this climate of competition, privatisation, individual responsibility and accountability that the newspapers reported on what they considered newsworthy about education during the reform years 1988-1999.

\subsection{Funding}

In keeping with the academic and professional literature (see 3.2 and 4.6) the funding substory contents were found to be the most frequently covered articles at the Budd score four and five levels. Funding articles pervaded all levels of educational concerns and will be discussed under the following headings in descending order of significance, as perceived by the media.

- Tertiary funding

- The role and ownership of universities

- Student funding - fees, allowances and loans

- Primary and secondary schools’ funding

- Kindergarten funding

- Commercial enterprise

\subsubsection{Tertiary Funding}

The neo-liberal proposals were presented with a dilemma when it came to funding tertiary education. Treasury accepted Brennan’s conjecture (Boston, 1990; see 3.3.3) that tertiary education benefited the individual only. Yet, Treasury also held the view that, in order to maintain equality of opportunity as a social function, state funding was justified.

To reconcile the diverse points of view the Government tried to resolve the issue by increasing student fees, means testing student allowances and later introduced a loans scheme based on the principle of user-pays accompanied by target assistance (see 3.3.3). The Government's aim was to increase access for the disadvantaged students, for example Maori, women and mature students as part of maintaining a level playing field or creating a 'decent society' (see 
3.3.3). At the same time the Government began to withdraw its total funding of tertiary institutions. Tertiary Institutions were now expected to become virtually self-sufficient.

Initially, the funding crisis was first published by The Evening Post (27 January, 1988) when it highlighted the funding pressures experienced by the universities brought about by the Government's commitment to 'open entry'. As a result of increased student numbers, particularly in "career" subjects, the existing funding arrangements had begun to "crumble". Although the Government had "compensated" for the increased student rolls this would be the last time it would do so. The 'new right' policies now expected universities to create their own funds. From now on the universities would have to bid for an increase of funds based in 'competition', rather than 'contest' (Easton, 1997; see 3.3.3), with the other providers of tertiary education, such as polytechnics and later, private providers. Furthermore, the Government expected the universities to spend money it had just allocated to "under represented groups such as Maori, Pacific Islanders and women.” But the universities responded by increasing student fees which reduced the 'open entry’ opportunity for such groups to attend and, in turn, created a polarisation between the 'have and the have-nots' (see 3.3.3).

In response to the funding constraints the University Grants Committee sought to develop a strategic plan, and because of the uncertainty of whether future funding would match increasing student numbers, the emphasis was likely to be one of, as yet unspecified, "reallocation rather than one of expansion” (The Evening Post, 27 January, 1988).

A short while later The Otago Daily Times (29 June, 1988) published a front page headline "Funding Crisis for University" which again raised the issue of Government funding as being "insufficient". With the withdrawal of the capital works funding how were universities expected to cope? Otago University in particular believed that, "Vitally needed new buildings were required to cope with the expansion of student numbers.” The Vice-Chancellor, Dr. Robin Probine, saw such insufficient funding affecting "the previously enjoyed 
benefits to Dunedin, Otago and Southland.” In short, the wider local economic and commercial well being was going to be adversely affected through the lack of University funding from the Government.

Furthermore the Vice-Chancellor could see that if:

The University continued, without increased funding, teaching and research standards would fall.

And as a result:

Important tutorial and laboratory teaching involving small groups of students would suffer because of the increased numbers and staff would become hard to recruit.

The options, the Vice-Chancellor saw, were either to increase restrictions or to raise student fees. Further, but longer term options, were to "sell, their education services to overseas interests" and to, "mount a fund-raising campaign." Probine "did not like seeing bright young people unable to enter the university." Nor did he like "seeing a system introduced which will make universities elitist institutions."

A further consideration was for more stringent restrictions on entry, this meant forgoing the existing 'open entry' policy to the University. This would be achieved by "reallocating scarce resources based on constant demand for more commerce and law students." In turn, this would have "the strongest effect [negative] on the faculty of arts and some areas of science.”

There was some opposition to the Vice-Chancellor's handling of the funding crisis. In the same article, Cliff Skeggs, Mayor of Dunedin and member of the Otago University Council, asked why Maori and Polynesian students were highlighted in the University’s special travel bursary provisions. Skeggs believed "we should all have equal rights... and he [Skeggs] was against any suggestion of favouritism.” The Vice-Chancellor replied that the Watts Report, 
as well as the Government, had emphasised 'the universities' need to encourage such students to attend.”

The equality of rights in terms of access meant different concepts to the members of the Otago University Council. Although the newspaper article did not report on how their differences were resolved during that meeting, newspapers would report on the resolutions and outcomes that Otago University made on such matters over the next few years.

The funding crisis for the University deepened later in the year with the publication of the Hawke Report's (Report of the Working Group on Post Compulsory Education and Training) recommendations. Of vital interest to the universities was Hawke's recommendation that the universities, polytechnics, teachers' colleges and other institutions (including private institutions) be entitled to equal funding based on the number of students they attract. In short, it would break the traditional hierarchy, which gave higher status and more money for each student attending universities.

The report's proposals received little attention with only three articles being published. All three articles were published on the same day, 27 September, 1988. The New Zealand Herald reported "Varsities Marked Down from Top Slot.” This article emphasised the equal footing polytechnics would now have in conferring degrees and being free to "mix" courses so students could “judge” the courses most suitable for them. Furthermore, funding would also be on an equal footing with the universities. The journalist thought that polytechnics would be unlikely "to compete with universities across the board, but more distant polytechnics in the region may do so."

However, the article proved to be quite wrong. Overtime, students opted for polytechnics in preference to universities because they were perceived to be more cost-effective with a better chance of employment once the course was completed. The neo-liberal policy of a competitive market was being reflected in consumer choice. The competition for the consumer dollar (for those who could afford it), based on the product (commodity) the institution had to sell, 
was being keenly felt throughout the whole of New Zealand's tertiary education sector.

The Otago Daily Times continued with the theme of "insufficient government funding” and restricted entry to Otago University during 1990, although by then Government funding was now seen as "underfunding” (14 December, 1990). The Vice-Chancellor, Dr. Probine, now saw open entry to be a "charade" if the funding remained inadequate. Three months later The Otago Daily Times (27 March, 1991) described the Vice-Chancellor's response to the Government's decision to withdraw \$2.76 million from Otago University funds as "mind-boggling” because of the "lack of consultation and natural justice.”

In particular, the University stood to lose 1000 distant-taught students at a "stroke of a pen" who were in "advanced training in health sciences and was a far cry from the undergraduate training offered extramurally by Massey.” Clearly the gloves were off in the newly competitive world when bidding for precious government funds. Furthermore, the Government's move would “threaten universities [ability] to market education overseas" - which the Government had been urging universities to do. Therefore, it was not only Otago University that would be implicated but all universities in New Zealand. So, while Otago University competed with other universities it could also see, on a wider scale, the possible negative affects the proposals would have to all universities' viability. By widening the negative effects, Otago University could be seen to be looking out for other universities and, no doubt, wanting their collective support to object to the loss of funding from the Government.

The increased commodification, competition, privatisation and conflict in the tertiary sector were not going to disappear. "Hard Questions on 'user-pays' today" (The Otago Daily Times, 30 May, 1991) were put to the Minister of Education, Dr. Smith concerning the "targeting" of middle and high income earners to pay more for their education. Considerable debate in the House followed but by June, Smith assured the House, and the public too, that “Tertiary fees [were] not a Goer” (The Press, 12 June, 1991). While targeting may not have been a 'goer' Smith continued to argue with the universities over 
funding issues and, tuition fees, in particular. The funding issue had become so serious that by 1993 it was an election issue. The Otago Daily Times (6 October, 1993) described Smith's row over the university tuition fee rises as having:

Gained ground in the debate over tertiary funding cuts, with a seductive appeal to voters based on the institutions' failed ivorytower status.

Smith suggested:

The universities had used their autonomy to stash away millions at the students' expense.

The universities, despite having had funding cuts, could not justify a rise in student fees because they were "swimming in cash." (This sparked a riot from the students. Student protest will be discussed later in this chapter). In addition to questioning the management and the integrity of Otago University, Smith believed:

The University’s own figures had failed to make 'efficiency’ gains and the University had chosen 'to pass' on to students the full extent of 'minimal' cuts to the course category instead of absorbing them itself.

As a result Smith sought, from all universities, management audits via the Official Information Act to explain their funding. The article went on to explain the operating surpluses as being "accounting concepts only." The University had actually ended with a shortfall. The article thought Smith had "universities on the back foot” by playing his "trump card in response - but [Smith] had played it clumsily."

By 1995 The Otago Daily Times (27 October) reported that the University of Otago had its funding close to the projected figures for 1996. The Vice- 
Chancellor, Graeme Fogelberg, was 'philosophical' about the $0.7 \%$ cut in the University's funding. He thought the University “could give itself a small pat on the back” for its continuing accuracy in funding projection. He rationalised that other Universities, for example, Canterbury and Lincoln, had received greater cuts. Any animosity or envy that other universities had received more was not apparent.

However, the ongoing and increasing withdrawal of Government funding, coupled with the increasing privatisation and commodification of University funding, had come at a price. As predicted by academic and professional writers (see chapter three) the universities' student rolls declined because of uneven costs in tertiary institutions which resulted in compromising the principles of open access (see 3.3.3). Funding costs had led to a drop in about 1000 in student numbers at Otago University. It was estimated that it would cost Dunedin’s economy \$1 million. To offset the loss Otago would "step up its marketing efforts in Auckland” (The Otago Daily Times, 27 October 1995).

In the same article, the President of the Students' Association, Miss Martin, saw the University's vulnerable position and appealed to the Otago community, on the grounds of their symbiotic economic relationship. Martin saw the University as being:

A vital part of Dunedin and Otago economy [and] appealed to the greater community for understanding and support for the University's position, which was being undercut by Government policies.

Clearly the University no longer expected the Government to come to the rescue. The University would take responsibility for recruiting students in a competitive market. The newspaper's emphasis was on the loss of important overseas distance-taught private fee paying postgraduates. Their fees were seen as crucial to the economy and well-being, not only to the University but also to the wider economy. 
Furthermore, the University did not, as Smith had suggested, see itself as having "ivory tower status”. The University saw its links, especially economic ones, being inextricably tied to the wider community and was aware of the vital coexistence each had on the other.

What the newspaper did not make clear was the type of New Zealand student that was being lost during this time. The academic literature (Parr, 1997; Peters, 1997; Boston and Dalziel, 1992; see 3.3.3) predicted the new regime would discriminate against, and therefore, bring inequality of access for Maori, Pacific Island and mature women - despite Government's expressed intent wanting minority groups to be given every opportunity to attend universities.

Early in 1996, the Act Party was reported by The New Zealand Herald (11 January, 1996) to have said that the current Government had made no provision for tertiary education to be Government funded in the future. In short, private funding would pay for higher education and the State would not be involved. No articles with a Budd score of five or four were found in the newspapers in response to the Act Party's scare mongering of privatisation; by 1996 universities had adjusted to Government underfunding and the new market ideology.

Later in the same year The Southland Times (21 October, 1996) featured an article by Dave Rohan, Chairman of the Southland Polytechnic Council, on the unequal distribution of funds following the Todd Report's recommendations (Report of the Ministerial Consultative Group on Tertiary Funding).

The Todd Report, under option 'A', had stated that the taxpayer per student subsidy would drop from an estimated 80 per cent of the tuition costs to 75 per cent by 1999. Student fees therefore, would not be more than 25 per cent of the course costs by 1999. The justification for the 75/25 public-private split funding was to reconcile the two diverse points of view held on tertiary education (see 8.3.1). 
The Todd Report indicated that the government should still make a substantial contribution to funding tertiary education to maintain the equal opportunity principle. Rohan's article asked when were politicians going to show some “integrity”. He noted the report had recommended a 75/25 public-private split in funding. Rohan also noted that it was in "tuition costs", not "actual Government funding costs”. But, by 1996, the newspapers' focus had shifted from financial survival to the management and distribution of financial resources within the tertiary institution itself. The distribution and management of the resources was now being recognised by newspapers as having an impact on staff morale.

An earlier article in The Otago Daily Times (25 June, 1993) had already hinted at the problem of distribution when a disgruntled member of staff from Otago University thought that extra funds may have been found to support a fellowship that had collapsed.

But when The Otago Daily Times (28 November, 1996) announced that further cuts in University expenditure in all areas were pending and reductions would be necessary in "administration activity" rather than in "academic activity" questions were asked about the University's management and distribution practises. Staff morale was reported as being "dangerously low" and questions were raised concerning the reduction in library and language courses. This article was of significance because the Vice-Chancellor chose to respond to a letter to the editor, submitted by Dr. H.W.Love, who brought the above concerns to the public's attention.

The Vice-Chancellor, Graeme Fogelberg, replied:

It is disappointing that you continue to receive letters from citizens of Dunedin criticising the University. It appears that they who have nothing to do with the day-to-day running of Dunedin's most important organisation believe they are better placed to make sound judgements about internal resource allocation than those of us who have all the relevant information at our disposal. 
Fogelberg presented figures showing that Otago University spent a greater percentage of its budget on academic staff than other universities, had a more favourable staff/student ratio and showed why there was an increase in Asian languages and a "static or declining demand for European languages.”

The Vice-Chancellor believed that he had to balance the scarce resources in the interests of the University as a whole and concluded:

Inevitably in the current funding climate this is going to involve the necessity for internal redistribution and not all decisions are going to be greeted enthusiastically by those who are adversely affected.

Fogelberg's response is a sharp contrast to his previous 'philosophical' acceptance of the Government's 0.7 per cent cut in funding 1995. This later reply is one of being very focused on the management and distribution of scarce resources. The University had become a business to meet the "demand" from students, especially in specific languages such as Asian languages. The concern for the University having an 'entrepot' function (Boston, 1990; see 3.3.3) had been overshadowed by the need to survive the realities of the new market economy.

\subsubsection{The Role and Ownership of the Universities}

The funding and ideological challenges facing the universities led to the question of ownership. Although not covered in the literature review, this topic occupied The Press and The Otago Daily Times after a Government review raised the issue in 1996. The Press (29 March, 1996) reported that the Government was feeling "increasingly exposed to risk as an owner of institutions in this field." Two review groups had advised that university councils should be smaller and more "businesslike" and there could be a "conflict of interest" when staff members were involved in councils. To minimise risk the government was advised to charge a "capital tax". Such a tax would not only offset risk it would also increase the "accountability of the university." 
The Press reported that the suggestions sparked strong reactions from the Association of University Staff, describing the appointment, by Dr. Smith, of the executive director of the Business Roundtable, Roger Kerr, to the Council of Victoria University was a "Trojan-horse arrangement designed to sway the Council towards Roundtable thinking on privatisation.” However, with a change of Ministers of Education, the matter stalled.

Eighteen months later the Green Paper on Tertiary Education was released. The Green Paper's proposals directed its attention to improve competitive standards, which would produce graduates relevant to New Zealand's needs, way of life and to be internationally competitive. The recommendations were based on the neo-liberal theory that tertiary institutions should become more efficient, with a focus on producer/customer relationships with individual students and with the crown acting as owner to protect the risk to the taxpayer. This latter proposal was an about face to the earlier proposal that universities become privatised.

However, the Green Paper too came under attack. First from Brian Gould, the Vice-Chancellor of Waikato University (The Press, 28 October, 1997) and the second from an editorial titled "Selling Education" (The Otago Daily Times, 10 November, 1997). Gould objected to the proposed model because it showed:

No consideration such as the national interest, academic independence, or the role of universities as critic and conscience of society.

The latter consideration Gould (1999; see 3.3.3) had written about in academic literature and one which he believed in firmly. With these ideas in mind Gould suggested an alternative:

Rather than to focus on the market-driven fallibilities, which would see New Zealand universities in a uniquely disadvantaged position...universities and Government [should] jointly identify 
those objectives which are desirable in the longer term interest for the $21^{\text {st }}$ century.

The editorial in the same Otago Daily Times supported Gould's opinions and described the Green Paper as being “contradictory” because while:

Promoting market forces to impel higher education....in terms of freedom of choice, it also proposes the imposition of strict Government control of the public universities and the right to appoint governing boards of directors...

The editorial saw the implications for Otago institutions, which would "mean a loss of reputation outside the region, a degree would count for little” and there would be a "population imbalance" brought on by the extra pressure. In all, Dunedin would not benefit. Not for the first time was an editorial appealing to influence the ' $A$ ' reader audience in the hope that those with influence might rally behind Otago institutions.

Finally, the editorial thought the Green Paper raised issues of "democracy". The thought of "unelected appointees meeting in secret" was being "autocratic" and therefore “democracy” was at risk of being lost. The editorial concluded:

The proposals outlined in the Green Paper define another severe threat to Dunedin and Otago. We doubt the principles of the Paper meet any test of national consensus.

The newspapers shared and supported the academics' views in respect of the University's survival. It also saw the loss to the wider community as well as the loss of underlying principles of freedom and democracy in the Green Paper's proposals of returning ownership to the control of Government in the name of market efficiency (see 3.7.3). 


\subsubsection{Student Funding}

Closely allied to the tertiary topic on funding was the issue of student funding. The tertiary education sector, to compensate for the shortfall in government funding introduced by the neo-liberal policies, looked to alternative ways of compensating for their losses. As a result student funding became a primary target based on the user-pays principle. Initially student fees were introduced followed later by student loans. The government also introduced student allowances and means testing to retain the 'level playing field'. But with the introduction of the new public management policies came problems (see 3.3.3).

This topic was covered in all papers with no significant North-South Island division found. The New Zealand Herald published seven of the nine articles found in the two North Island newspapers, while The Otago Daily Times provided six of the nine articles published in the South Island newspapers.

The first issue raised was the student loans scheme and was initially published by The Southland Times (28 February, 1989). The article, and the only international publication on the topic, had a headline "Battle looms in Britain over Student Loan Scheme." The article described the opposition to implementing such a scheme and thought such a scheme was unlikely to go ahead.

In New Zealand, newspapers reported uncertainty about the viability of such a scheme. The New Zealand Herald and The Otago Daily Times (both on the same day, 6 July, 1989) reported that students would now face a \$1500 increase in tuition fees because the loan scheme had been scrapped. The Otago Daily Times reported the Opposition spokesman on education, Dr. Smith, describing the collapse as:

A victory for students, as even the Government's "vindictive" threat to slap lump-sum $\$ 1500$ fees on them next year, was not as insidious as the loans. 
Mr Goff, Minister of Education, believed the students, having rejected an "interest free loan scheme”, would be worse off. Students would now have to arrange with a bank to have a loan and pay interest. Contrary to the Labour Government's intent, student fees would also rise to offset tertiary costs. Goff thought the opposition put up by the universities' students' associations to get the banks to withdraw from the 'interest-free scheme' had done the students “a grave disservice.” But the President of the Otago University Association, Simon Rudd, "Welcomed the end of the loan scheme", although why he did was unclear.

The Registrar of Otago University, Douglas Givan, had mixed views on the collapse of the scheme. On the one hand he saw it as "prohibitive" but on the other, expressed "uncertainty" about how to offset costs given the underfunding that already existed. Clearly, the University had a serious dilemma to resolve.

With the collapse of the loan scheme the Government now opted to provide a means-tested assistance to students from low-income families so as to bridge the considerable increase in fees. Furthermore, the Government also recognised that, "Students on courses which would be unlikely to channel them into highpaying jobs would be exempt from the increased fees”(The Otago Daily Times, 6 July, 1989).

But students had already become 'wary' of taking courses that did not lead to work. The New Zealand Herald (15 February, 1989) had highlighted this when students, because of the high course fees, had avoided new courses in forestry because there was no guarantee that work would follow once the student had completed the course. Students now saw education linked to employment and were not prepared to pay high fees without such an opportunity to work being in place. Therefore, with students now opting for 'vocational' courses the government paying tuition fees to those qualifying for such a scheme was not going to be too costly. 
However, the reported demise of the loan scheme was premature because within a short time the scheme was introduced. But by then overall interest in reporting the scheme as a 'single issue' had declined and only another two articles were published. Both publications came from the South Island and both were concerned with the illegal use of loans. The Southland Times (22 December, 1991) reported that a student had been prosecuted for misusing the benefit system. The student had been receiving both the unemployment benefit and, at the same time, the students' only benefits.

The Otago Daily Times' (29 September, 1992) headline reported “Law to make students payback Government loans likely soon.” The law was to close the gaps that had enabled students to misuse their loan money and to require them to repay their loans with interest. Such misuse of loans had not been contemplated in the academic literature, nor would it seem by those who had advised the Government in the scheme's implementation.

The predicted $\$ 1500$ fee increase for 1990 was eventually set at $\$ 1250$ (The Otago Daily Times, 8 September, 1989) and was initially accepted without any apparent reported opposition in the newspapers. However, by 1990 with an election looming The New Zealand Herald (28 September, 1990) reported that the "Student vote may swing key seat." Opposition to costs in higher education were beginning to bite and the students were calling for voters to vote against the Labour candidates seat in the Hamilton-East electorate - even though they acknowledged the National candidate had not helped them to overcome their plight. The students were now appealing to the public to help vote out the Labour Government. Whether or not such appeals were successful is uncertain because there was a change of Government with the National Party being elected into power.

Despite the change of government the funding issues remained unresolved. A letter to the editor of The Evening Post (17 December, 1994) from John MacCormick, student representative of Victoria University Students' Association, replied to a previous article on the topic (The Evening Post, 13 
December, 1994). MacCormick pointed out that, because of the deliberate underfunding by the Government, tertiary institutions had been:

Forced to pass this underfunding on to students and families. The recent report highlighting the dramatic 35 per cent increase in student indebtedness and evidence from Victoria University’s own student hardship fund clearly points to rising poverty which must impact on the quality of study and the numbers undertaking tertiary education.

MacCormick agreed with the previous article that the student fee rises were unnecessary and the reason for it was because "the Government is clearly in a position to fund the growth in the numbers of students...but chose not to.” MacCormick believed the University was:

Now operating a much more sensible programme for financing new buildings, and I understand that the University is not using student fees to fund its building programme.

The student fee increases had created considerable hardship for students, increased indebtedness and students were concerned how the University used their fees. They wanted accountability and transparency in the way the University managed them.

With the announcement that tertiary fees would increase by an average $\$ 400$ over the next five years (The New Zealand Herald, 11 January, 1995) students invaded the Auckland office of the Ministry of Education in protest. Although the announcement had been made through the university vacation, students had responded from universities and polytechnics throughout New Zealand and had vowed "to keep up the protests" even if the Minister, Dr. Smith, thought it “a dead issue”. The President of the Waikato Students' Union, Alayna Ashby, believed: 
Increasing fees further will increase the numbers of people who cannot afford to invest in their future, even when they know it will improve their earning capacity in the long term.

The fundamental right to a good education, and ultimately a good future, was being denied them because of financial barriers.

While the students objected to the increased fees there was a general acceptance of the fee increase among the administrators in tertiary institutions. Mr Armstrong, who had been a member of the Todd Advisory Task Force, believed that "Universities and polytechnics had been absorbing costs for years rather than passing them on in recent years.” This view differed markedly from academic writers and students (3.3.3).

During 1995 reporting on student fees continued. The New Zealand Herald's (11 January, 1995) headline "Fee rise to deter students: Professor" was in response to the Todd Report's 'Option A' for the Government to cut spending and to increase student fees, while the headline in The Press (27 October, 1995) raised the possibility of a "Fee Scare as University’s funding cut.” Both papers held similar views that were expressed in earlier publications.

By 1996 the observations made by Parr (1997; see 3.3.3) had already began to make headline news. "School-leavers by pass university: professor" (The New Zealand Herald, 7 May, 1996). Professor Gould attributed the 'by-passing’ to:

The growing cost of student loans and fees... First year enrolments had dropped for the third year running, [and while] overall numbers had 'held up'... [it] was because students from earlier years [were] going through the system. But increasing fees and debt levels from student loans were putting off the next generation.

Gould thought there had been a "vicious downward spiral" as the universities tried to cope with a 12.5 per cent reduction in Government funding since 1990 . Such a "philosophy of doing more with less money could see New Zealand 
degrees less valued internationally.” In contrast, enrolments at polytechnics were up. Gould suggested that:

Many students who wanted to go to university were deciding on a shorter, cheaper polytechnic course instead.

But, Mr. Vince Catherwood, Manager from the Ministry of Education's Tertiary Funding office, did not see the quality of education being compromised through lack of funding to the universities. Catherwood believed that the decrease in the universities' student rolls might be explained by “a drop in the number of students leaving secondary school.” Although he was not challenged on this point, the literature review in chapter three does not support his view, particularly by Parr (1997; see 3.3.3). There had been a steady increase in student numbers attending polytechnics during this time as The New Zealand Official Yearbook 2000 had shown (see 3.3.3).

The Alliance Party, in the same article, launched a "free access" to tertiary education at a cost of $\$ 825$ million on top of the present funding. There was an alternative to the TINA principle (see 2.5), if the public voted for them.

The protest and conflict continued late into 1996 with The Otago Daily Times publishing two articles on the difficult issue of student funding. The Otago University had agreed to meet with the students in a "Bid to resolve student issues” (The Otago Daily Times, 17 August, 1996). However, the distribution and management issues remained unresolved, so much so, that a parent advocated that students protest over increased tertiary tuition fees and Government underfunding (The Otago Daily Times, 25 September, 1996). Meanwhile, Auckland argued that because of the "Higher cost of learning" (The New Zealand Herald, 22 November, 1997) Auckland should receive more.

By now the student funding issues, as a significant newsworthy source, were beginning to fade. Ironically, the penultimate article was a letter to The Evening Post's editor (12 December, 1998) from an unsympathetic former 
student. The student compared his experience of living on the unemployment benefit with his experience of living on a student allowance and had found that there was very little difference, in terms of hardship, between the two. The former student concluded that students should accept what they were given and live on it. The last article, a student contribution, was published in The Otago Daily Times (29 October, 1999) with the headline, "Young Voters not bothered by Elections.” Their political stance to influence election outcomes in the hope of altering the ever-increasing cost of tertiary education had faded. The acquiescence of student protest is assumed to be due to the increased workload. It could also be due to the neo-liberal policies where competition and rugged individualism is expected leaving little time for collective negotiating.

Significantly absent from the newspapers publications at the Budd score four and five levels, were the increased indebtedness and the negative impact such indebtedness had on family and relationships which academic writers had discussed (see 3.3.3). Nor were there any significant articles found such as those written by Gordon (cited in Snook et al, 1999; see 3.3.3), drawing the public's attention to graduates leaving for greener pastures and the cost of that loss to New Zealand.

\subsubsection{Primary and Secondary Schools’ Funding}

Although over 2000 primary and secondary schools, and well in excess of 600,000 students (The New Zealand Official Yearbook, 2000:110) were affected by the educational reforms, there was surprisingly few newspaper articles on funding topics reporting about their issues. The fourteen articles in this category were fairly evenly dispersed among the North and South Island papers. Notably, The Evening Post had three letters to the editor on this topic. The articles in this section supported the literature review (see 3.3.1) and in particular, the underfunding and the unequal distributions of scarce financial resources were the key issues.

Two letters to the editor of The Evening Post (8 September, 1989 and 4 October, 1989) submitted by A.C. Scott highlighted the contentiousness of the issues. Scott's first letter headlined “Teachers are not grandstanding over 
funding." Scott pointed out that under the new structure, contrary to Dr. Ballard's ideas:

That funding to schools had increased 9.6 per cent... there had been no significant redistributing from the new structure, (and may indeed suffer from the loss of economies of scale); and there is no obvious value for money for our children out of the restructuring.

Scott supported the teachers' view and concluded:

Dr. Ballard would have us believe that teachers are grandstanding in their concern over funding... abuse is a poor substitute for an argument. What he seems unable to provide is a rational justification of his decision to give so little of Vote Education to schools and so much to the administration's new bureaucracy.

Scott's second letter continued the theme in the belief that the "Extra Education funding won't go into schools." Scott believed the money would be split in such a way that "will grossly disadvantage our children in schools, but will promote enormous growth in new departments and quangos.”

This letter concluded that Mr. Goff, Minister of Education, should appoint another task force and call it "Administering for Excellence - mark ll”, but this time the excellence would be to "students' learning, rather than to the growth and working conditions of the new Treasury inspired bureaucracies.”

The contentious issue of distribution was also keenly felt by The Otago Daily Times (5 October, 1991) when it published a report that the "Lions share" of capital works funding had gone to five schools. There was general concern about the iniquitous distribution that had left equally deserving schools, out in the cold. The 'new right' policies hurt and the community, through their local MPs, lobbied the Minister of Education for a fairer and more equitable deal. The resistance to the introduction of 'new right' policies had now developed political overtones. 
Further ripples were felt when The Otago Daily Times (19 October, 1993) reported that the Labour Opposition Finance spokesman, Dr M. Cullen, had suggested, during an election campaign, that the National Government planned to lower schools funds. Yet the public, in a poll conducted in The Press earlier in the year (18 May, 1993) had found that, "if there was any extra government money to spare, people generally would prefer to see it spent on services such as the police, education or other public services.” It was clear the poll wanted a more equitable distribution of government funding on services based on a welfare state.

The Minister of Education, Lockwood Smith, conducted a survey "to find out about educational issues in the Selwyn electorate" (The Otago Daily Times, 28 July, 1994). This led to complaints to the State Services Commissioner from the School Trustees Association. They believed:

All schools in the Selwyn electorate have the same needs and concerns as schools in the rest of the country.... The association has been telling the Minister of Education about these concerns for a long time - the key issues were adequate teaching resources and support.

The issues continued unabated and by 1995 The Press (29 July, 1995) warned that a "Cash crisis looms for Canty Schools", and a letter to the editor of The New Zealand Herald (9 November, 1995) also objected to the underfunding of state schools while at the same time the Government was funding private schools. The headline, "In schools to them that hath it is indeed given" succinctly summed Constance Finnigan’s opinion.

The key issues by 1996 were reaching crisis point. The headline on the front page of The Press (1 June, 1996) read:

Voters focus on health, education. Politicians must address key issues survey shows. 
The newspaper had commissioned the University of Waikato to survey voters to identify the election issues. Health and education were identified as the two key issues and The Press would "report the election campaign" on those identified issues. Voters in particular wanted more money spent on education believing that "Every New Zealand child was entitled to free state education." Furthermore, the voters believed, "the opportunities were not equal and the poor were penalised.” One voter said that:

Education used to be an investment for the future, but now only the wealthy can afford it.

Voters also were concerned about class sizes and high teacher-pupil ratios. They "felt the poor areas needed more support for teachers, funding and assistance ” and, voters also wanted teachers’ strikes to end.

While most of voters did not have the figures available to them that academic writers had access to (see 3.3.1), they were acutely aware of the effects Government cuts and underfunding had had. The majority wanted all New Zealand children to have the opportunity to a free state education that would not only benefit them, but would also be an investment in the future. In short, they wanted to return to the welfare state model of the state.

There followed a three-year gap in any significant newspaper articles concerning the management and distribution of funding and school resources. In part this was due to the change in the Ministers of Education in 1996, when Wyatt Creech replaced Dr. Smith. A feature article by Martin Cooney, former President of the PPTA described Creech as "Masterful at clearing up Mess" (The Evening Post, 12 March, 1999). Cooney outlined six major crises schools had faced in 1996 and had hoped that Creech would reverse the Government's policy. However, under the new MMP, Cooney believed that Creech had little option but to go along with his predecessor's plan. While Creech did settle problems, Cooney criticised him for "not leaving with the education system any fairer, more efficient or with higher standards for our young people” and 
concluded Creech had, "delivered the social services by the market." The contentious issues, while they had been quelled, still remained.

Throughout the nineties newspapers paid scant attention to management within schools. An early edition of The Otago Daily Times (14 July, 1992) had published a full-page article giving "The Unofficial List of School Boards of Trustees”. The Southland Times (23 March, 1995) featured a main page article briefly outlining the responsibilities of the boards of trustees. Current trustees interviewed in the article described the experience as "rewarding".

Less enthusiastic about boards was a letter to the editor of The Evening Post (6 September, 1997) submitted by John Wilkinson. He had attended an Island Bay School Board of Trustees meeting where there had been considerable dissension between the board and parents. Wilkinson complained that the meeting had been "one-sided" because the trustees had not allowed parents to speak. Because of the limited number of newspaper reports about boards of trustees it was difficult to assess the PPTA's prediction that inexperienced parents would find having their responsibilities as trustees a ‘burden’ (see 8.2). Equally difficult to assess was whether or not boards of trustees were aware of their loss of 'voice' with the incremental recentralisation discussed in the literature review (Barrington, 1998; Snook, 1989; Snook et al, 1999; Nash, 1989; Codd and Gordon 1991; see 3.7; 3.7.1; 3.2.1 and 3.7.3).

However, while Creech was 'masterfully' clearing up the mess, new problems were emerging in terms of school management. Wylie thought that it was a rare exception that schools could "self-manage" well and believed self-managed schools were "not the whole answer to management" (The New Zealand Herald, 1 September, 1998). The article reiterated her opinions discussed in the literature review (see 3.3.5; 3.4.1 and 3.4.2) in which parents and students lost choice because competition between schools was seen to foster a more conservative approach to education rather than innovation and diversity. Wylie concluded "Overall standards [remain] static or drop.” The article highlighted the complex effect that the education policies, including funding, had on the education system. 


\subsubsection{Early Childhood Education}

Newspapers largely neglected this sector of education. Only two significant articles were found in this study. The Southland Times (14 July, 1992) article supported some of May (1999; see 3.3.2) and Wylie’s opinions (1993; see 3.3.2) in terms of 'downsizing' the kindergartens. The newspaper article reported that, although The Southland Kindergarten Association had stayed within its budget, it had taken considerable effort to achieve it. Teachers had had increased workloads, increased paper work (since the introduction of bulk funding) and fees would need to be introduced, even though the association thought few parents could pay them. Parents were now being asked for a “voluntary donation”. Fund raising had been "stretched" and would not meet the shortfall in bulk funding.

The association was reported to be "now trying to balance the books" rather than focusing on the "quality of teaching". Such changes they believed had:

Brought about an 'undermining of teachers' conditions and the quality of education [and] a rift between the association and the teachers had developed, only since bulk funding.

The inequalities Wilson et al (1996; see 3.3.2) found were only beginning to be hinted at. In a later article in The Evening Post (30 August, 1996), when the funding crisis was at its peak, Rosslyn Noonan (National Secretary to the NZEI) elaborated on the critical state of early childhood education. Noonan pointed out that:

Kindergartens have been the cornerstone of education for 108 years. They are cost effective, free and accessible to all families and they must remain so.

Noonan saw that there was now:

A powerful ideology that government's responsibilities should be reduced, that kindergartens should be removed from the State 
sector and a "neutral" funding policy applied to diminish

kindergarten funding levels and introduce user-pays.

Noonan feared that kindergartens under current Government policy would move to being purely bulk funded, although the unions would oppose it. She believed that:

We all have a responsibility to let the Government know we want our kindergartens and all our community early childhood services - to flourish not flounder.

The newspapers do not trace the impact funding cuts, and bulk funding in particular, had on early childhood education. Academic and professional writers (see 3.3.2) found that the quality of teachers and teaching declined as untrained parents filled in. Furthermore, the community's ability to raise funds varied greatly, which created inequalities between individual kindergartens. Voluntary help also declined, as parents were not as supportive as before the reforms. Parents were now returning to work and /or were unable to meet the user-pay principle that the 'new right' policies had introduced.

\subsubsection{Commercial Enterprise}

In response to the changes in State funding of institutions and the reforms enabling schools to market their services, newspapers reported on their commercial enterprise activities. Business sponsorship was also vital to make up the shortfall in government's underfunding of schools. Business contributions were acknowledged in newspapers (which could also be seen as a form of free advertising) by being placed on the paper in high Budd scoring positions. Commercial enterprise was largely a South Island phenomenon with 11 of the 13 articles coming from those papers. The story contents fell into two categories, fundraising and sponsorship, and, commercial enterprise and the tertiary sector. Each category will be discussed separately. 


\subsubsection{Fundraising and Sponsorship}

Newspaper articles reported on a wide range of activities. The Southland Times (14 September, 1988) devoted a full-page list of grants the local trust bank had contributed to many institutions, including schools. The headline read "Who is giving back to the Community?” Sponsorships also featured in The Southland Times (18 February 1995) and The Otago Daily Times (21 July, 1993). For example, The Otago Daily Times reported on a science fair competition for schools sponsored by a local electricity company. School and pre-school children were reported to be fund raising and had a wide range of activities varying from a scarecrow competition (The Otago Daily Times, 5 September, 1994) to establishing a café "to quell rumbling tums" at a high school (The Evening Post, 17 February, 1993).

A more controversial way of fund raising was used by Riccarton High School. They had raised $\$ 30,000$ by selling 'scratch-and-win' tickets at the instigation of the principal (The Press, 11 February, 1994). In the same article, "School means Business" the principal had deliberately sought Asian fee-paying students and had "no intention of cutting back" the intake. The money raised went into sports uniforms and "suddenly the kids were saying 'hey representing this school actually means something'." The principal had also set up a professional development programme and staff morale had been improved.

This article is interesting for the new image that the school had created by being successful in the new competitive market. Whereas the principal in Stirling's article (2002:19-23; see 3.4.2) had successfully repackaged and remarketed the school's image by making the decile three school look like a decile ten school. Each school had succeeded in being commercially enterprising, but in different ways. In both cases the principals, after initial criticism, had made their schools attractive places to be for staff and students alike, as well as gaining the support of the wider community. For these two principals and schools the 'new right' policies were working for them with very satisfying results. 
The above newspaper article also allayed some of the concerns, as well as reflecting some of the positive aspects, of Asian fee-paying students that an editorial, "Exporting Education" had referred to earlier (The Press, 28 September, 1990). What was less clear was the editorial's question asking if the foreign earnings brought "real equity" to the education system as a whole. The editorial expressed the same concerns as Wylie (1999a; see 3.3.5) by highlighting the educational implications of a market driven economy in terms of the lack of equal opportunity for school children as a whole. So, while some schools had made the commercial enterprise transition, there remained serious concerns for the lack of equality of opportunity for all schools under the 'new right' policies.

\subsubsection{Commercial Enterprise and the Tertiary Sector}

The Otago Daily Times and The Southland Times concentrated on the importance Otago University had to Dunedin's economy. The publications cover a short period, 1997, but highlight the crucial link between the University and the region.

Both newspapers published feature articles on 18 April, 1997 and both accentuated how important students were for Dunedin's "Vibrant life style and economy." The Otago Daily Times emphasised the advantages of Otago University in comparison to other universities. The Mayor, Suhki Turner, said

“ I am not critical of Auckland or Victoria Universities, but they are commuter universities." While Turner emphasised the "scarfie life style” Otago offered the Vice-Chancellor, Graeme Fogelberg, was reported to be "passionate about Otago University and its student life style.” Fogelberg thought Otago University was in "fair shape" after axing 89 staff positions the previous year. He acknowledged "the tertiary market is getting tougher and Otago has felt the pinch.”

To help alleviate the pinch Otago University had sold its educational services overseas with the result that overseas students had earned the university $\$ 13.5$ million. Gone were the anxieties raised in the early 1990s when the Hawke 
Report's recommendations threatened 'distant-taught' students (see 8.3.1). The University now turned its attention to New Zealand students and had:

Lured more New Zealand students by telling other universities that students wanting to do first year health sciences have to do it in Dunedin, not on their home campuses as in the past.

In short, under neo-liberal policies competition was tough and the University was prepared to poach students from other universities for its survival.

The local business groups thought Dunedin should be branded "The City of Learning” (The Otago Daily Times, 28 October, 1997). This would include Dunedin's University, Polytechnic and College of Education as well as, businesses, service industries and companies that used "brain power". The President of the Otago Business Beyond 2000, Mr. Gilks, saw Dunedin building its economy around the "products", to use the neo-liberal vernacular, of that resource.

Southland's District Mayor, Frana Cardno, after attending a population conference in Wellington, saw the implications of the drift north, low fertility and an ageing population that had led the area to a "demographic crossroads" (The Southland Times, 12 May, 1997). Cardno realised that the necessity for Southland and Otago having a well-educated population being "paramount for survival.” Cardno's answer was to promote and to educate Southland and Otago regions.

While the commercial enterprises appear to have overcome Otago University's financial problems the local business community did not fare so well. The final article from The Otago Daily Times (6 July, 1999) was a contribution from Helina Tomaszewska, a $\mathrm{PhD}$ student, who believed "partnerships were required for survival.” Her interest lay in the managing of change within business organisations. Tomaszewska challenged organisations to raise their performance that included, developing partnerships instead of leadership, and to create jobs instead of complaining and downsizing. Tomaszewska expected 
business to contribute to the growth of the economy too. The inference being that unless there was suitable work available in the region then the educated would go elsewhere.

One last publication on commercial enterprise came from The New Zealand Herald, 4 January, 1999. The headline read "Tertiary Research: now big business.” As the headline suggests the universities had made the transition into the market economy, but as Tomaszewska's article implies, the market economy had to change to complement the universities’ transition.

Five years later the 'closed shop' of Dunedin's business community remained. Proudly known as the "Tartan Mafia”, the Otago Chamber of Commerce chief executive, John Christie, saw nothing wrong in having a ‘closed shop' group of all white males, aged between 50 an 70 years, even if it was seen as cronyism that exerted undue influence and created "jobs for the boys" (The Dominion Post, 19 May, 2004). Such attitudes reflected the neo-liberal ideology of being anti-feminist, anti-Maori and, although unintentional, it is ironically, anticompetitive.

\subsection{Summary}

Initially, the newspapers preferred to ignore negative professional opinion in favour of reporting positively on the proposed educational changes during the 1988-1989 period. Toward the end of that period there was a change in tone in newspaper reporting, particularly from the editorial in The New Zealand Herald (16 May, 1989) which was firmly against assistance from the welfare state and very supportive of the 'new right' policies.

As the neo-liberal policies were implemented during the 1988-1989 the newspaper articles with a high Budd score concentrated on financial topics with a total of 88 contributions. The South Island newspapers in particular published the most articles on the survival of tertiary education, especially in relationship to the areas' economic survival. The South Island papers were also concerned about ownership of universities and commercial enterprise 
across the education spectrum and, again, it was closely linked to the areas' economic survival under the 'new right' policies.

The 'new right' policies aimed to increase the access for a wider range of students to tertiary institutions. The student funding policy was aimed to meet that objective. However, with the ongoing underfunding, cuts and unequal distribution of funding among the tertiary institutions from successive governments, there followed an intensive competitive era between tertiary institutions and, in the climate of 'user-pays', the institutions passed the costs on to the students. Student funding became a deciding factor in where students spent their scarce resources. It also became counter-productive to the minority groups that successive governments had wanted to assist.

The opposition to the increasing student fees, student loans, means testing of allowances, and the increasing indebtedness that the neo-liberal policies introduced were covered by both North and South Island newspapers, particularly the student protests and political lobbying in opposition to such schemes. Only one letter was found to be openly unsympathetic toward the student allowance.

Newspapers however, failed to report on the impact that increased indebtedness had on students, their family and relationships. Nor did newspapers cover the cost to New Zealand when graduates sought work overseas to offset their costs incurred under the 'new right' policies.

Primary and secondary schools' funding and the new commercialism were also of concern to most newspapers. This topic also elicited the most letters to the editor concerning the lack of equitable distribution of funds under the 'new right' policies. Despite schools becoming more commercially enterprising many of the articles, including an editorial in The Press (28 September, 1990), showed that the public wanted a return to the welfare state ideology in terms of equal opportunity for all children. They believed that the ever increasing polarisation between the 'have and have nots' was not good, either for the children's future or New Zealand's future as a whole. 
The newspapers gave little attention to management by the boards of trustees and the three articles found gave mixed views. Given the pivotal role boards of trustees were to have under the Picot reforms it is very disappointing to see such few articles on the topic. Furthermore, with the incremental recentralisation during the 1988-1999 period that this thesis covers, it is uncertain whether or not the newspapers deliberately ignored the board of trustees' loss of 'voice'.

The most neglected area of reporting was in the early childhood education sector. Indeed, it could be described as the 'Cinderella' of newspaper reporting despite academic and professional writing showing that the neo-liberal ideology policies had had a severe impact on early childhood education's funding and other resources.

While resistances to the funding changes introduced by the 'new right' policies were reported across all education sectors and in all newspapers, some of the ongoing financial problems identified by academic and professional writers were not followed through in newspapers. Therefore, some issues in the public mind would be left unresolved when a paper had lost interest in the issue.

In addition to leaving funding issues unresolved, it was found that newspapers did not have the same breadth or depth of coverage to issues as those found in academic and professional writing. Not surprisingly, the newspapers focused on the wider implications and impact the 'new right' financial policies had, or could have, on the educational and economic survival of the community and New Zealand as a whole. 


\section{CHAPTER NINE - DISCUSSION: Part Two}

\subsection{Introduction}

The previous chapter discussed finance, the most dominant story content topic found in the research results. This chapter will focus on the remaining results and will discuss the similarities and differences as compared with the views of academic and professional writers.

\subsubsection{Overview of Part Two}

This section will present a discussion of the main themes that emerged, in descending order of significance as perceived by the media, under the following headings:

- Teachers' salaries and employment conditions - this focuses on two subtopics, bulk funding and teachers' salaries and employment conditions. The latter subtopic will cover, pay parity, strikes, redundancies, resignations and staff shortages

- Curriculum, assessment and qualifications - this covers the changes and objections to the social studies and cultural safety programmes, the criticisms arising from the changes in the content of the English programme and the rise of the new 'vocationalism' subjects

- Minority groups - this covers minority groups and/or the recognised disadvantaged groups, for example, Maori, Pacific Islanders, women and mature students

- Finally a summary will draw the salient points together

\subsection{Teachers' Salaries and Employment Conditions}

Treasury claimed that the fiscal crisis of the welfare state had arisen through three forms of capture; consumer, provider (teachers) and administrative. Each of these groups had only shown self-interest and it had been at the expense of those in need (see 2.4).

In response to those criticisms the education reforms shifted the administrative responsibilities downwards to educational institutions. The Picot Report recommended that two funds be established. The first fund would be for the 
day-to-day running expenses for the school and the second fund would be a 'bulk fund' for teachers' salaries. While the first fund was implemented in early 1990 the bulk funding of teachers' salaries, along with government underfunding and cutbacks, and teachers' employment conditions remained bitterly controversial (see 3.3; 3.3.1 and 3.3.2).

The response from newspapers to these issues revealed a North Island-South Island division with The New Zealand Herald and The Evening Post providing 15 of the 23 publications. The funding issues were seldom reported as a 'single issue' topic and have been divided into two categories, bulk funding and teachers' salaries and employment conditions.

\subsubsection{Bulk Funding}

Sullivan (see 3.5.) asserted that by 1997 teaching was in crisis. Shona Hearn, President PPTA, warned of the "Coming Crisis for New Zealand Education" in a Press article as early as 27 March, 1991. In particular, Hearn saw bulk funding as a significant contributing factor in the forthcoming crisis. She believed that while direct bulk funding was given to schools to juggle staffing with insufficient funds, Government would still hold the purse strings, but it would be the trustees who would take the blame when forced to make impossible decisions. According to Hearn (The Press, 27 March, 1991) those impossible decisions that schools would have to make were:

- Fewer, experienced teachers (who cost more) or more less experienced teachers (who cost less but may not have the experience needed);

- Dropping subject, thus affecting their attractiveness;

- Increasing class sizes, thus affecting their teaching effectiveness;

- Not replacing teachers when they leave;

- Downgrading the positions of responsibility;

- Drawing off funds from operation grants;

- Raising money from their communities. 
Hearn thought the last two decisions would increase inequality between schools because the poorer schools and areas would be at a disadvantage.

A. A. K. Grant in a letter to the editor of The Evening Post (21 August, 1992) objected to bulk funding for different reasons. While he thought the PPTA as having the "worst excesses of the wharf unions in their hey day" he thought trust was at issue. Teachers, Grant claimed:

Along with New Zealand, have learnt that this Government, like the Labour Government before it, cannot be trusted to keep its promise. Once bulk-funding is in, it can be fiddled.

Further objections came from Martin Cooney, President of the PPTA (The New Zealand Herald, 31 January, 1997). Cooney pointed out that universities, polytechnics and kindergartens had been bulk funded and all sectors had realised the "flaw" in such a scheme because, "Government can reduce the amount of funding a student [receives] as it chooses” and the institution has to make up the shortfall. Cooney saw Kindergarten bulk funding as "bulk underfunding." While only 10 per cent of the 2,700 schools had accepted bulk funding, Cooney did not think the situation would be "so rosy" if all schools were bulk funded.

Not all articles were opposed to schools being bulk funded. An editorial in The New Zealand Herald (9 June, 1997) warned “Teachers' Yellow Alert” now that Mrs Shipley was the new Prime Minister. The editorial thought that Mrs Shipley would "tackle the perverse way teachers are paid." The editorial supported bulk funding because it believed, "those who [were] paid from the government coffers" created social inequalities and at the same time it was economically inefficient. The editorial advocated payment on school rolls. Schools would then be "more likely to employ a more balanced staff and poorer schools would find it easier to hire and keep better qualified teachers.” In turn, this would improve the quality of teachers. 
The editorial was scathing of the crude industrial tactics teachers had used to resist the change. The editorial saw such tactics as "only serving to protect the power of national officials and jobs of those whose performance [was] substandard." The editorial considered the losers were the vast majority of teachers who would do better by direct bargaining and the public who were deprived of the best educational arrangements that could be made for their money.

A similar view was held by P.J. Verner, a teacher, who in a letter to the editor of The New Zealand Herald (5 December, 1997), thought teachers had been mislead by the unions and that the unions had "the nation by the throat."

The battle lines were drawn between the unions and most teachers on one side who feared that government funds would be steadily reduced if all schools were bulk funded. On the other side were mainly non-teachers who believed that the quality of teacher would be improved by a more competitive and accountable stance that the 'new right' policies provided. Provider and administrative capture had to go to make way for a 'laissez-faire', competitive market that would yield better education results as well as an improved economic efficiency.

\subsubsection{Teachers' Salaries and Employment Conditions}

The tension between neo-liberal ideology and teachers' salaries and employment conditions was at its greatest in this substory content and supported academic and professional writers' (3.5 and 3.5.1) views that the newspapers were not 'teacher friendly' when it came to this topic. Newspapers were even less friendly when it came to teachers' unions.

Mathew Dearnaley, reporter to The New Zealand Herald, 22 April, 1991, was sceptical at the 'no pay rise' proposed by the primary, secondary and kindergarten unions. Dearnaley saw this as:

Making a dramatic offer to go without a pay rise for the sake of renewing their awards without industrial strife. 
Rosslyn Noonan (National Secretary to the NZEI) denied the claim and saw it:

Not as an offer of desperation among unions trying to retain their power...but one of reasonableness under new laws (The Employment Contracts Act).

By 1994 pay parity had become newsworthy. The Southland Times (28 July, 1994) featured secondary school principal, Bill Verrall, arguing why secondary school teachers should be paid more than the primary and intermediate teachers. He contended that secondary schools had to compete with other industries because they could offer more attractive employment offers. Therefore, to attract and to retain secondary school teachers, they should be paid more.

Despite Verrall's reasoned argument the strikes for pay parity continued to feature throughout the late 1980s and 1990s. The Southland Times (25 March, 1989) focused on the effect strikes had on the pupils and the wider community. Although schools had made provision for children to attend school while the strike was on, the children failed to attend. The inference being, that the children got up to mischief because of the strike. A second article, this time in The New Zealand Herald (3 March, 1995), reported on the primary and intermediate teachers' strike for pay parity giving similar reasons found in previous publications. Amid the strikes and disputes The Evening Post (15 July, 1994) suggested "Mediation could cut school disputes.” The suggestion fell on deaf ears.

The final negative comment on teachers' strikes came from David Lange (The Press, 23 July, 1996) who thought secondary school teachers being paid while on strike was "risible". The State Services Commissioner had taken a year to appoint a new chief executive to the Ministry of Education and during that time Lange believed "it had laid the ground for the 'Treasury Gnomes' to run the ministry." Given Treasury's tough and rigorous stance, Lange predicted that "we can look forward to bulk-funding, the privatisation of the ministry's property and financial services and its eventual emergence as a small policy 
unit.” Lange concluded that "only the incurably naïve would announce a settlement with the post-primary teachers' association.”

Despite Lange's dire warnings the call for pay parity continued and widened to include 'performance reviews'. Margaret Clark, Professor of Political Science at Victoria University, reminded the public that the NZEI was not only fighting for pay parity but also against performance reviews and assessments (The Evening Post, 11 January, 1995). Clark suggested that "the ultimate assessment of all teachers are their students and that assessment will be for life.” Clearly such outcomes had not only short term but also long term implications.

Clark's second feature focused on "Monitoring the performance of Academics" (The Evening Post, 9 March, 1994). This article discussed the considerable weight placed on academic shoulders when interviewing possible candidates for academic positions. Clark anticipated that the universities would have a staff shortage in attracting and retaining "quality" teachers because of underfunding.

Although Clark's articles, along with on or two other articles in this section, provided a more measured approach to the complex issue of teachers' salaries and employment conditions, they were largely overshadowed by very negative and derisory articles from most newspapers.

\subsubsection{Recruitment, Resignations and Redundancies}

Throughout this period newspapers reported on the problems of staff employment. "A Fairer Deal” was wanted from the staff being made redundant from the Central Institute of Technology (The Evening Post, 8 September, 1989). This was the only significant article found on redundancy. Resignations became more newsworthy as teachers left because of low pay, heavy workloads and low morale (The New Zealand Herald, 14 April, 1994, and The Otago Daily Times, 2 January, 1998).

Retaining staff called for desperate measures. The New Zealand Herald (2 January, 1998) reported that "Principals dig deep to retain teachers." The 
principals sought to offset government cuts and, at the same time, stop staff resignations by paying for staff from their own pockets.

Despite a teacher shortage, three articles reported on the difficulty 'would be' teachers had in gaining a teaching position. The Southland Times (5 June, 1992) featured an article reporting on the difficulty that ethnic minority teachers had in finding employment, while a letter to the editor of The New Zealand Herald (12 July, 1999) from the PPTA President, Graeme Macann saw the recruitment of overseas teachers as "flawed". Macann thought New Zealand had sufficient former teachers who, with some re-training, would successfully meet the shortages and at the same time save the Government money.

Another letter to the editor of The Otago Daily Times (13 August, 1999), signed "Disillusioned", thought the teaching profession a "closed shop". As a New Zealand born, raised and trained teacher, she had been told to "look for a job overseas" while schools recruited teachers from overseas.

A further two letters were published concerning 'teachers extended holidays'. The New Zealand Herald (20 April, 1999) reported comments from the new Minister of Education, Nick Smith, that "teachers had too many holidays." Teachers, in reply, had considered this to be 'teacher-bashing'. Warwick Roger continued the controversy in The Evening Post (3 May, 1999). "Hands up if the teachers are getting precious” was his invitation to the public. Roger countered various arguments teachers put forward for the extra holidays; he advised the reader to "get in touch with Nick Smith to ask some more questions of the teachers on your behalf.”

The issues reported in the newspapers were not seen as "symbolic of an underlying ideological clash” as Sullivan suggested (1999; see 3.5; 1997 and 1999; see 3.5.1). The newspapers were not union friendly. Teachers received a mixed response but, in keeping with Sullivan's findings (see 3.5), generally the publications tended to be negative, especially when it came to bulk funding, strikes, workload, performance and holidays. No newspaper investigated the 
reasons why there were teacher shortages while, at the same time, there were teachers who wanted to teach but schools would not employ them.

Any 'collegial' relationships that existed (Snook et al, 1999; see 3.5) were not reported. Instead, disagreement was found among teachers, between unions and teachers, and within unions. For example, Martin Cooney, President of the PPTA, vowed to fight for his position after being sacked from it (The Press, 3 November, 1998). While the academic writers (Sullivan, 1999; Marshall, 1997; Marshall a et al, 2000; Gordon, 1993; see 3.5 and 3.5.1) had focused on the underlying differences between the reforms and the educational and professional ideologies, the newspapers, in keeping with Kim’s findings (1989; see 4.6), focused on the turmoil, tension and the controversies of the day-today events.

\subsection{Curriculum, Assessment and Qualifications}

Changes in these areas began in the early 1990s when the National Government introduced 'seamless' education that encompassed primary, secondary and some tertiary levels. Such a scheme was to give New Zealand a competitive edge in an ever-increasing economy by producing low cost 'flexible' skilled workers to reflect those changes. As a result the curriculum, assessment and qualifications became highly specified to meet criteria specified by the Education Review Office (ERO), the New Zealand Qualifications Authority (NZQA) or the Ministry of Education (see 3.5; 3.5.1; 3.6 and 3.6.1). Teachers viewed these as a further uncoupling of their professional role in favour of neo-liberal ideology (see 3.5; 3.5.1; 3.6 and 3.6.1). This section will discuss those changes in the curriculum, the NZQA and the ERO under their respective titles.

\subsubsection{Curriculum}

The first draft document on the changes to the national curriculum was published in 1991 and was followed by a national curriculum framework in 1993. The framework specified seven essential learning areas and eight groupings of essential skills. There was a parallel curriculum statement for Maori to follow. Accompanying those lists was a set of National Educational 
Guidelines (NEGS) to help schools implement the curriculum changes (see 3.6.1).

While the curriculum changes were in the main accepted at primary and lower level secondary schools (see 3.6.1), academic and professional writers, for example Elley (2000; see 3.6.3), were critical of the 'structural soundness' of the curriculum which was to enable the student to pass through the 'seamless' education programme.

Other academic and professional writers were highly critical of the way in which the unit standards and the curriculum had become commdodified to establish a new 'vocationalism' based on busno-technocratic beliefs (Marshall, 1997; Marshall et al, 2000; Roberts 1997; Codd, 1997; see 3.6.3).

The nineteen newspaper articles published on these topics were fairly evenly divided between the North and South Islands. The Otago Daily Times, however, had no publications on this topic. The newspaper articles had a different emphasis than the academic and professional writers on the curriculum changes. The newspapers' focus was largely on the changes to the content of social studies, which included cultural safety, the changes to the content of the English curriculum and the positive effects the newer sunrise subjects, that encompassed the new 'vocationalism', would have on the economy. The curriculum changes met with diverse opinions in terms of their function and quality.

\subsubsection{Social Studies and Cultural Safety}

The National Opposition spokesman on Education, Lockwood Smith, received a strong response to his proposed 'back to basics' programme. Smith's proposal was to teach maths, science and a modified form of English, while at the same time dropping social studies because "it was being steadily politicised by the Government” (The Evening Post, 19 July, 1989).

The first objection to Smith's proposals was immediate. Mary Varnham, in the same Evening Post (1989) criticised such "inequality as being hardly 
appropriate for our time.” A second criticism from The New Zealand Herald (5 October, 1991) raised the same objections but also asked if a liberal education was so wrong?

The answer to the question came from R.H. Lockstone (The New Zealand Herald, 30 July, 1997). While he thought the 1997 second social studies draft was "more concise" and "more user friendly" than the previous draft in 1994 Lockstone thought the changes were "still grandiose" and as "nebulous" as before. Furthermore, it was "impossible" to see social studies, as a subject because it was "not compulsory" and therefore, social studies was, Lockstone concluded, a “non-subject... tinkering with pupils' personalities” and that ultimately the subject cheated both the taxpayer and children.

The concern about gender inequality was highlighted in research results published by Alton-Lee and Nuthall. The study (see 3.7.2) reaffirmed gender and racial inequality bias in the classroom (The Press, 1 July, 1992). Articles on racial issues however, overshadowed gender bias.

Anthony Haas (The Evening Post, 15 October, 1997) encouraged the Asian community to contribute their ideas toward the new social studies programme. The new programme, Haas thought, "should be able to increasingly focus students on investigating similarities and differences in diverse cultures.” Haas saw the benefit to New Zealand as a whole given that New Zealand was "a nation of migrants.”

Further racial issues were raised when a student objected to being part of a 'cultural safety' programme as part of a nursing course at Christchurch Polytechnic (The Southland Times, 21 July, 1993). The article raised a number of complex and competing concerns. An unnamed academic thought independent critical thinking should be encouraged, not stifled; at the same time a professional was expected to meet "the holistic needs of the patient" and not just pay "lip service” to cultural awareness. Others thought it was "political correctness gone too far", while Ranganui Walker believed that "most students 
were forced to regurgitate what they believed their tutors wanted to hear.” Walker saw:

The Treaty of Waitangi as a charter for equality, which set out the rights for both Maori and Pakeha, with neither having the right to ride roughshod over the other...Pakeha have got to learn to relinquish power and Maori have got to learn to use power responsibly when it is given to them.

A month later The Press (3 August, 1993) reported that the "nurse culture may alter”. Teaching ‘cultural safety' was being reviewed. A further article from The New Zealand Herald (4 July, 1995) reported on "The secrets of teaching Cultural Safety" showing that such a subject could be taught without rancour, if respect was shown.

Racial issues were also to be found in early childhood education. Mary Varnham's article (The Evening Post, 11 April, 1996) was in response to a teacher stripping the cross off a pupil's hot-cross bun on the grounds the parents might be offended "by blobs of sweet edible dough." Varnham thought such an action had missed the point. "Acquainting people with existing beliefs and customs other than their own is not proselytising." Varnham contended, "It is a was a way of overcoming ignorance.... by teaching them you may just create a tolerant society.”

While the gender and racial issues had focused on equality and tolerance within social studies and cultural safety subjects, newspapers also reported changes in the English curriculum.

\subsubsection{English Curriculum}

Four newspaper articles reported the changes in the English curriculum. Lyndsay Perigo, an experienced broadcaster and well-known right wing supporter (2002; see 4.3), described the new curriculum as "Turning minds into mush” (The New Zealand Herald, 6 February, 1995). Perigo believed: 
All students must learn the conventions of English...Students should explore and develop an understanding of...grammar, or the way words and phrases are formed.

Perigo thought:

Such grudging concessions are enveloped in an-all-too-familiar fog of political correctness, groupism, emotion-worship and fatuous flow charts.

Criticism was not confined to the non-teaching sector. Agnes-Mary Brooke had taught secondary school students and asked if "New Zealand was a Democracy or Dumbocracy” (The Southland Times, 21 June, 1995). Brooke had found it "sobering" to see how "bright young students had found it difficult to absorb basic grammatical and syntactical concepts never encountered before." She thought with the omission of these two "vitally important contentions” the new English syllabus had:

No perspective outline of what must be taught and when in the hands of teachers whose own competence in this area is recognised as minimal, it is shockingly inadequate.

Warwick Roger's article (The Evening Post, 1 May, 1995) shared a similar view but also suggested there was "Paranoia in the education industry." Roger's article extended to criticise teachers for being afraid of "competition” and:

If teachers were doing their job properly, and if they used methods of teaching reading that makes more sense than look and guess, there would be a greatly reduced need for the work of Professor Clay.

"Just blame it all on that despicable lot - the teachers" was the headline in a letter to the editor from Pam and Stewart Laird (The New Zealand Herald, 6 January, 1997). This letter was in response to teachers being blamed for the 
“appalling state of spelling.” The Lairds offered a wider view to include class size, children with mixed ability and lack of resources in and out of the classroom.

The proposed changes to the English curriculum had stimulated a diverse response from people with very diverse opinions and agendas. Criticism had been levelled from the poor quality of content, to the teachers being afraid of competition to a wider view of the class size and mixed ability children. The English curriculum was not merely a subject and any changes to it were not going to be made without criticism from members of the public.

\subsubsection{The New Vocationalism}

The rise of the new vocationalism was criticised for structural soundness regardless of the child's ability or future occupational journey. Not only were academic and professional writers critical of the structural changes but also Michael Irwin from the Business Roundtable, shared similar views (see 3.6.3). Furthermore, the new vocationalism was criticised for knowledge becoming so refined in a technocratic sense that it was seen as being too inflexible and too simplistic for complex learning, thus becoming counter-productive to the intentions of neo-liberal ideology (see 3.6.3).

Such a simplistic view was illustrated by John Blakeley, Executive Director of the Centre for Advanced Engineering at Canterbury University who thought Tomorrow's schools had given "scant regard to the purpose of education" (The Press, 18 June, 1990). Blakeley supported the National Party's policy on education and believed that if women (ethnic minority groups not mentioned) took subjects such as physics and chemistry they would achieve equality. In turn, the work force would become employed in "high wage jobs". Hence, New Zealand must work at developing a "skill-intensive economy". His views mirrored the new 'vocationalism' based on 'busno-technocratic/instrumentalist' beliefs referred to in the literature review (Marshall, 1997, 2000; Roberts; 1997; Codd, 1997; see 3.6.3). 
However, just 'how' that would be achieved in the workplace was unclear. Women, having made considerable achievements in the educational arena, still remain unrepresented in what are known as 'male dominated industries' and are still being paid, on average, $80 \%$ of the average male income (The New Zealand Official Yearbook, 2000:317). Furthermore, coupled with women's other responsibilities and commitments, there is little provision in the workplace to accommodate those matters, especially in a society where neoliberal ideology holds sway (remember The New Zealand Herald's editorial, 16 May, 1989).

Blakeley's vision of the technocratic future was endorsed by further newspaper publications. Four articles reported very favourably on computer technology and science. The New Zealand Herald (1988 and 1989), The Press (1997) and The Southland Times (1995) shared similar views that computers were seen as being important to the economy for the new 'Information Technology' age if New Zealand's economy was to be competitive.

A fifth and final entry in this section came from The Southland Times (1 September, 1998) reporting on "Excellence through sport." The article praised the new sports scheme that had been introduced to secondary school boys. The scheme had led to positive results and offered career opportunities in sport, which the article endorsed. This last entry encapsulated the move away from the more contentious liberal studies such as social studies and 'appalling' standards of English in the early 1990s, toward the scientific-technical market ideology where excellence would be well defined through attaining standards based on measurements. The course's knowledge would come from sports sciences, which was also based on the same principles of excellence, competition and measurement, and this would equip those who succeeded to follow a career based on the same principles.

\subsubsection{Assessment and Qualifications}

In keeping with the changes to the curriculum there was an accompanying change in assessments known as the National Assessment Guideline (NAGS) for schools to follow and implement. While teachers were confident in the 
delivery of the curriculum content, Wylie (1999; see 3.6.1) found teachers were less confident in assessing the curriculum. Furthermore, much time was lost assessing children rather than focusing on what teachers wanted to do - teach (see 3.6.1 and 3.6.4).

The second level of criticism (see 3.6.5) was a culture of distrust that had emerged in the relation to professional accountability. Codd (1994; see 3.6.5) believed that there was a clash between the 'professional-contextual' model, under which teachers worked, and the 'technocratic-reductionist' model of the 'new right'. As a result of the tension and conflict between these two ideologies a culture of distrust had emerged. The tension and conflict identified by Codd was identified in the thirteen articles found in this category and fell into two subtopics. The first concerned the effect the New Zealand Qualifications Authority (NZQA) was having on universities and the second subtopic was a more general discussion on assessment and qualifications.

\subsubsection{Attack on the Universities}

The Hawke Report promoted the merging together of what had previously been 'vocational' and 'academic' distinctions between post-compulsory education and training (see 3.6.3). As a consequence, the newly established National Qualifications Authority (NQA, later known as NZQA) challenged and threatened the traditional role of universities.

The Press provided all five articles criticising the effect that the NQA would have on the traditional role of universities. Resistances to the proposed changes were first published in The Southland Times (23 May, 1990) when Otago University Chancellor, James Valentine, saw the Education Amendment Bill as being “conceptually flawed.” The Chancellor objected to the Education Review Office and the NQA having "the power to enter universities and inspect the work of individual staff members and their students" under the proposed changes. Valentine believed the universities already had "adequate administrative structure in place” and the proposed changes in the Bill would “impose too uniform a regime over all tertiary institutions.” 
The position of the universities came under further attack when the NZQA gave permission to a management school to use the name 'university'. Dr. David Novitz, a Reader in Philosophy at Canterbury University, wrote a feature article (The Press, 21 August, 1992) explaining why universities were opposed to the NZQA granting the title to such a school.

In Novitz's view:

Universities have their systems in place to ensure their appointments, their promotions, their teaching and their research meet with international standards.

Specifically, it was the "quality of standard" that Novitz saw threatened by the NZQA wanting control over it, even though "the NZQA had no international standing" in this matter. Novitz believed the traditional university in New Zealand was "the cornerstone of our liberal and democratic society" and under the Education Amendment Act saw that those traditions were being “dismantled”.

A counter-argument followed from Professor Sir James Stewart, former Principal of Lincoln College and chairman of the qualifications' authority. Stewart's article (The Press, 3 September, 1992) refuted Novitz's claims saying that Novitz had shown a "regrettable neglect of accuracy." Stewart outlined the standards that the NZQA worked to and denied that the Government was trying to direct universities to perform any particular research or work.

Novitz's reply, published immediately beneath Stewart's, remained unconvinced that university autonomy was not at stake. Novitz shared the same opinion as Gould (1999; see 3.3.3) and believed a tertiary institution could not be a 'university' unless it was a "repository of knowledge and a critic and conscience of society.” Because the Asian Pacific Institute taught only management subjects it would not satisfy the two conditions and therefore, it could not be considered a university. Novitz saw the NZQA's granting of the 
title of 'university' to such a body as a "serious threat both to university autonomy and academic freedom.”

Furthermore, polytechnics were also of concern to universities (The Press, 29 March, 1996) for the same reasons that Novitz and Gould (1999; see 3.3.3) have outlined. Polytechnics failed to do high level research and therefore did not have the same function or status as universities.

A third objection to the changes came from the proposal for secondary schools to teach university subjects under the 'seamless' education banner initiated by Dr. Lockwood Smith, Minister of Education (The Press, 1 November, 1993). Colin Burrow, retiring Reader in Ecology at Canterbury University, reiterated similar arguments to those of Novitz's. Burrow's also believed that secondary school students would be too young to grasp the more "high powered" concepts taught at the university level.

According to The Press (29 March, 1996), fundamental to the universities' concerns was the belief that:

In a few years this will result in secondary school students attaining credits toward degrees in school. The blurring of the line between school and university follows the smudging of lines between universities and other tertiary institutions.

The outcome of such a prediction was not followed by any further significant newspaper reports. This was in sharp contrast to academic and professional literature. The latter had been extremely concerned about the possibility of unit standards being applied to the universities and the intended merging of what had previously been clear distinctions between academic and vocational curricula (see 3.3.3; 3.6.3 and 3.6.5).

While newspapers reported only on the wider role and functions of universities in relation to secondary schools and other institutions, some of the newspaper 
articles shared with the academic and professional writers' serious reservations about unit standards in their existing form.

\subsubsection{General Criticism on Assessment and Qualifications}

Criticism came from a wide cross-section of individuals and groups interested in this topic with the North Island papers in particular having the most publications (nine), while The Press published the remaining two. The Otago Daily Times and The Southland Times had no publications at all in this section.

Michael Irwin (1999), representing the Business Roundtable (see 3.6.3), criticised the sweeping curriculum, assessment and qualification changes as requiring "more flexibility in dealing with students of different abilities, interests and aspirations” (The New Zealand Herald, 25 May, 1994). Irwin, having been commissioned by the Education Forum, proposed, as an alternative to the Government's changes, three interconnecting pathways from form five onwards that would have corresponding methods of assessments and qualifications. But unlike the literature review (see 3.6.3) no article was found highlighting the inbuilt contradictory problems that Irwin's recommendations had created. Indeed, the newspapers provided no further publications with a high Budd score on Irwin's alternative proposals.

One of the most contentious single topics that were reported by newspapers surrounded the proposed changes in school examinations. A letter to the editor of The Evening Post (3 December, 1994) submitted by Ian MacKinlay, Assistant Principal of Auckland Grammar School, saw School Certificate as having a "proven passport" and should be kept, while two further articles in The New Zealand Herald (15 October, 1997) discussed the pros and cons of using league tables to show the schools' effectiveness. Such results could be misleading, especially if the pupils were discouraged from sitting the exam if they were likely to fail, alternatively, for the school not to publish the result of those who had failed which would give a false impression of the school having a high pass rate. 
Warwick Roger (The Evening Post, 4 October, 1999) supported the ideas of Nick Smith, the National Government's Minister of Education, on 'exams and tests'. Roger believed that by introducing such a scheme of national tests and exams in reading, writing and numeracy for 9-11 year old pupils' educational standards would improve. Roger, as in his previous articles, extended the argument to include criticism of teachers. The tests would make teachers accountable. What Roger failed to see was such ongoing assessments came at a cost (Wylie, 1999; see 3.6.1) and teachers, to protect themselves from such assessments, had 'teacher proofed' the curriculum (Apple, 1993; see 3.6.1), ultimately to the detriment of student learning.

However the most scathing criticism was again aimed at the NZQA. Douglas Myers, chairman of The Business Roundtable (The Press, 20 May, 1996) described the NZQA as a:

Bureaucratic monster... seeking to micro-manage the content of New Zealand education in a way that would have been the envy of a Soviet education planner.

Unit standards, which the NZQA administered, also came in for scathing criticisms from Joe Bennett, a former schoolteacher. Bennett had the same article published in The Press and The Evening Post (24 November, 1999). Interestingly the headlines vary, although the content was the same. "Another edifice built on fallacies" was the headline in The Press, while the headline in The Evening Post read, "Rottenface-saver for Education Botch-up.” Bennett described the NZQA's unit standards as being "silly", that it had been financially costly in that it had taken "truck loads of money" to implement and to maintain. He also commented on the early departure of Dr. Blackmur to his native Australia, before his contract had ended. (Blackmur had challenged the NZQA's role and function.) Bennett concluded that it had taken the Ministry of Education and the NZQA a long while to realise what everyone could see from the start, that they would never work. However, Bennett believed that for the sake of change, the National Certificate of Educational Achievement (NCEA) was "being rushed in for the sound educational purpose of saving face." 
Bennett predicted that, like unit standards, the NCEA would collapse, but not before even more teachers left teaching, thus perpetuating the teacher shortage. His advice for teachers was to:

Join the bureaucracy. You won't have anything useful to do. You'll toss around dollars like autumn leaves. You won't be held accountable for your mistakes. But you'll have a job for life.

Neither Bennett's articles nor that of Myers focused on the specific content that was highlighted in the academic and professional literature (Elley, 1996; Codd, 1997; Roberts, 1997; McKenzie, 1997 and Harold et al, 1999; see 3.6 .3 and Wylie, 1999; see 3.6.1). Newspapers, however, were concerned about the wider and broader implications that the effect NZQA and unit standards were having to the economy and to the teaching profession.

\subsubsection{Educational Review Office (ERO)}

Initially, the Audit and Review Office (later changed to the Education Review Office) was well received because it was seen as assisting schools rather than inspecting them. This changed in 1990 when the Lough Report recommended the office refocus its role to assessing compliance and evaluating quality of service delivery (see 3.6.4).

Since the changes, academic and professional writers have been critical of the rigid, narrow and often silly demands made of the compliance requirements ERO have insisted upon. As a result teachers have 'ERO-proofed' their schools at the expense of teachers being engaged in more creative, diverse and reflective teaching (see 3.6.4).

The three articles on ERO provided mixed reporting. Ernie Barrington, a former assistant teacher at Auckland Metropolitan College and Higher Education Research Officer at Auckland University was critical of a poor ERO review his former school had received (The New Zealand Herald, 26 May, 1995). Barrington argued that "ERO is critical of a school such as this, because the educational establishment has always been suspicious of alternative 
schools.” Barrington argued for more freedom, not less for students because the current school system is "socially and intellectually stultifying." Barrington's comments are more colourful than those in the literature review (see 3.6.4). His comments reflect the academic opinions (Snook et al, 1999; Thrupp and Smith, 1999; see 3.6.4) in experiences as they are played out in day-to-day living. Barrington's article also shows that such narrowness of focus, geared to a market ideology not only clashes with educational ideology (see 3.5 and 3.5.1) but also undermines market ideology by being too inflexible and rigid.

However, the remaining two articles praised the role of ERO. The Evening Post (11 January, 1995) devoted the full top half of the page to local schools' ERO reports. Petone Central School had won high praise from ERO, saying the school "was a model for the best of the reforms under Tomorrow's." ERO outlined the reasons for the praise, which included, "an excellent partnership between board and school." Teachers had focused "their teaching role in high quality learning and teaching programmes" and "attitudes of students was reflected in their work.” Tikanga Maori was at the heart of the school.

A second article, this time in The New Zealand Herald (2 September, 1998), gave a history of an upper-middle-class primary school that had received a damning ERO report in 1993. But after "experiencing tumultuous years” in their relationship with ERO, the school was now receiving good ERO reports and as a consequence, the school now saw ERO as a "critical friend".

These two articles are of interest because first they show the change in a school's attitude toward the reviewing process and how 'compliance' had been attained. Second, unlike the Thrupp and Smith study (1999; see 3.6.4) that believed lower socio-economic schools received poor ERO reports, the reverse was shown in these two publications.

While the newspapers were critical of assessment and qualification changes, they did not report the unexpected 'paradox' that had arisen from the changes that academic writers such as Codd (1999), McKenzie (1997), Fitzsimons et al 
(1999), Wylie (1999), Thrupp and Smith (1999) had recognised (see 3.6.6). Furthermore, no significant article was published asking the question about what was worth learning and seldom reported the negative affects, identified in the literature review (see 3.6) that such narrowly monitored assessment standards had created.

\subsection{Access to Schools}

A division between the North and South Island was found on this topic. Six of the seven publications came from the South Island with The Press publishing the most with four articles. The Evening Post (21 June, 1995) was the only North Island publication. The newspaper's headline “Living - Wellington's schools your choice” accompanied a full-page list of schools. The list provided information about each school including the school's decile status information and the parents were left to make the decision.

The Picot reforms were intended to give parents and students freedom of 'choice' (see 3.4) in the State school education system. Four newspaper articles reported on different aspects of accessing schools based on 'choice'.

The editorial in The Press (14 April, 1990) raised the dilemma of funding independent schools. Teachers at an independent school had taken a pay cut because of a shortfall in the Government funding. Underpinning the argument of whether or not teachers should have taken such a stance, was why should State funds support an independent school in the first place when well-heeled parents could pay for the privilege. The editorial noted that because parents and the school co-operated as a partnership, the independent school was reflecting what the Picot reforms had intended for all schools, including state schools.

The editorial acknowledged that State funded schools catered for a wider mix of student, which was largely determined by the school's location, therefore the idea of attending a school of one’s 'choice’ was, for most parents and students, a 'myth'. 
The role the independent schools played, although being small, was important from a political point of view. The editorial took the view that should Government policy decide not to pay independent schools, parents who believed in such schools would continue to support them, and in turn this would create elitism based not on preference but on wealth. The editorial concluded that the role of independent schools was "to prevent centralism and education dictatorship from the Government.”

Ward Clarke, Principal of Hillmorton High School, held a different egalitarian view (The Press, 14 March, 1991). He regarded any society that claimed to seek excellence and equity for all students by abolishing zoning did so at their peril. After refuting claims that, "parents with money gravitate to good neighbourhoods in catchment of schools they regard as successful," Clarke described all secondary schools in Christchurch as providing excellent education. Students, Clarke believed, should have "equality of opportunity", but it would not lead to "equality of achievement" because not all students were of “equal intellectual ability”. Therefore, rather than measuring a school's worth by exam achievements, schools would be better measured by the performance of "ordinary” students. Furthermore, Clarke thought schools should reflect the wider society regardless of where the school was located. Therefore, any society that was serious about excellence and equality for all students would not accept abolishing zoning.

Clarke's opinion on egalitarianism is not reflected in academic writers' views (Thrupp, 1999; Snook, 2000; Dale, 2000; see 3.4.1). Their studies suggest rather than all secondary schools being of 'quality', the social mix is likely to lift the levels of student achievement in the middle and upper classes settings and reduce the levels in the low socio-economic groups. In addition, the Smithfield project (see 3.4.1) found that the Christchurch parents from low socio-economic backgrounds were unable to send their children to the school of their choice and, in particular, Maori and Pacific Island children missed out. In turn, this had had a detrimental effect on their educational progress and a 'spiral of decline' had followed thus creating a polarisation between 'the haves and have-nots' . 
Nyalle Paris, a secondary school teacher, also held an alternative opinion to Clarke's (The Southland Times, 5 December, 1996). Paris contended that vouchers would be a "positive and innovative step" which would increase parental choice, equity and competition in the schooling system. Therefore, zoning should go. Contrary to the egalitarian approach held by Clarke, Paris thought parents from lower-socio-economic groups would also benefit from the use of vouchers because they could use them to send their children to private schools. Furthermore, the increased competition between the schools would improve performance and delivery of services to 'the consumer'. However, Wylie (see 3.3.4) believed that the quasi-voucher system that already existed in New Zealand blurred the lines between state and private schools further perpetuating inequalities.

A second editorial, this time in The Otago Daily Times (3 May, 1999), discussed the 'enrolment schemes' that had been introduced the previous year to "tackle the problems in Auckland and to a lesser extent, Christchurch." The new law aimed at lessening the overcrowding and possible 'gerrymandering' (Wylie 1999; see 3.4.1) of popular schools following the removal of 'zoning'. The editorial noted that the change in law was to enable children to attend their local school, reduce cost to the taxpayer and at the same time provide "wide spread parent choice and competition for pupils as stimulants to education equality." After a discussion on the possible difficulties three schools would have in implementing the competing demands, the editorial concluded that the scheme was a "compromise" but "good secondary education opportunities were still available if the first choice failed."

The editorial's comments, having failed to see the paradox that the enrolment schemes had created, coupled with the empty rhetoric of the less desirable schools providing good opportunities, must have been of cold comfort to parents and students alike when it was the schools, rather than they, who ultimately had the choice.

Two Press articles reported on schools restricting entry either by charging Asian immigrant students' additional tuition fees (18 February, 1995) or by 
erecting barriers to entry on the grounds of the student being unable to speak English (2 September, 1995). The latter publication, an editorial, quoted Dr. Maris O’Rourke, The Ministry of Education's Chief Executive Officer, "categorically saying, that the school had no power to impose a residency clause as a way of screening out recent immigrants to New Zealand.” O’Rourke maintained that it was “every child's right to a free education if (he or she) is a New Zealander.” However, the editorial denied the argument, expecting immigrants to speak English "as a cultural form of bias and a clandestine means of creating a racist immigration policy.” The editorial concluded that the immigrants "should be prepared to make English their adopted tongue.”

The newspaper articles reflected in part Wylie’s findings' (1999; see 3.4.1) on the problem of 'oversubscribing' in relation to zoning. But the newspapers failed to see the effect it had on children from lower socio-economic areas, Maori and Pacific Islanders and the 'spirals of decline' that inevitably followed. Furthermore, if there was a 'starting-gun effect' as suggested by Gorard and Fitz (1998; see 3.4.1) newspapers failed to report about it.

The discussion in the editorial of The Press (14 April, 1990) about independent school funding, and Paris's opinion on vouchers, supported the academic writing of Codd et al (1990; see 3.4.1) that financial capital can be converted into educational capital. Furthermore, such capital would not only give 'voice and choice' (Boston, 1999; see 3.4) to exit schools but to also exercise power and influence over the central agencies. It is questionable however, if the central agencies would be in such a vulnerable position given the subtle ways in which recentralisation (Barrington, 1998; see 3.7.1 and 3.7.2) had returned power to them over the 1988-1999 period.

The question of Asian students being exploited, either by being charged increased tuition fees to teach them English, or by excluding them because their English was not acceptable, was a hitherto unknown problem prior to the reforms. The problem emerged from the reforms when schools sought to augment their funds by introducing their educational services to overseas fee 
paying students. The literature review did not cover this problem because there was insufficient academic literature available on this topic during the period under study.

\subsection{The invisibility of Minority Groups}

One of the main aims of the reforms was to increase and open up access for minority groups to education. For example, provision was made in the Picot Report for Maori to establish their own educational institutions if mainstream institutions failed to meet their needs.

However, tensions have arisen between the report's aims and the market ideology. The 'new right' policies have been heavily criticised for their lack of consultation with Maori, lack of cultural sensitivity and an imposition of an unwanted Pakeha education system while at the same time failing to enable Maori to develop and maintain their own culture as a democratic right (see 3.7.2). More recently Pacific Island and other minority groups have also added their voice to wanting to develop and maintain their own culture as a democratic right (see 3.7.2).

Newspaper reporting on minority groups was largely conspicuous by its absence. Four articles were published on this topic. The New Zealand Herald (17 November, 1988) reported on the proposal for teaching Maori as "having upset English teachers.” The Maori teachers' group of the PPTA had put forward a remit at the PPTA conference that all secondary school children should be taught Maori but this was strongly opposed by teachers who taught English. The reasons for such opposition were based on several 'myths', which included Maori culture and language having little relevance to teaching English. The majority of teachers concluded that it was more important to focus on teaching English, not Maori

Two articles reported on Maori successes. The "School of Hope" headline (The Press, 29 January, 1992) referred to the opening of a new school that encompassed Kohunga Reo, Kura Kaupapa and Wananga. It was recognised 
that Maori were underachieving and the opening of such a school would give hope for improved achievement for Maori.

The second article, published in The New Zealand Herald (1 September, 1998), reported on the success of a Kura Kaupapa Maori School that was committed to addressing the demise of the Maori language and Maoritanga. The school had addressed the needs of Maori children by adopting an 'holistic' approach. The Principal, Beverley Manahi explained that under Tomorrow's Schools they had been given the option to establish such a school but "despite the nod from politicians of that era, the educational option was given no viable means of support - then or now." Manahi was looking forward to the time when:

We stand on an equal and equitable platform, no longer having to play catch-up with the education system that has had more than a 100 years to get established when politicians and the powers that be finally acknowledge that the time has come to address the future for kura kaupapa Maori.

This sole article epitomised the ongoing struggle Maori had experienced for the past 100 years irrespective of reforms. Manahi had, in a few short words, encapsulated the accounts found in the literature review about the disadvantages Maori have endured (see 3.7.2).

The fourth reported article (The New Zealand Herald, 31 May, 1993) focused on School Certificate and bursary examination results for 1992. The School Certificate results reported that "Asian students did best with 17.7 per cent scoring an 'A' grade, only 2 per cent of Maori achieved the top grade and 1.6 per cent of Pacific Island students.” In the bursary examinations, 25.4 per cent of Pakeha received an 'A' grade, compared with 33.8 per cent of Asians and 7.2. per cent for both Maori and Pacific Island students. No comment was given explaining the possible underlying reasons for such results. 
Other minority groups, for example, Pacific Island children and the newly identified disadvantaged group, boys, were not found to be reported at the Budd score four or five levels. All three Maori articles had a Budd score of four. Publications about other minority groups and/or disadvantaged groupsPacific Island children, women, mature students and boys remained in the lower Budd score levels.

\subsection{Summary}

This chapter found that newspapers reported on the tensions, borne from resistance, acceptance, ambivalence and contradictions, to what appeared at first a seemingly simple task of implementing the education reforms in a climate of neo-liberalism. Differences in reporting those tensions were found not only between newspapers but also between the North and South Islands.

The South Island newspapers, especially The Press, had concerns about access to schools in terms of 'choice' and 'equality of opportunity' for all children to a decent education. The articles highlighted the difficulty of implementing such complex concepts. Alternative notions of equality of opportunity were reported but they too were shown to be flawed in the light of academic and professional research. Regardless of the opinions put forward, there was an agreement that education reform, in offering parents a 'choice' and 'equality of opportunity', were seen as 'myths'.

The NZQA was also of concern to The Press, a topic of concern that was shared with North Island newspapers. However, the content between the North and South Island articles varied. The South Island newspaper articles focused on the NZQA relationship to the universities, specifically, the loss of academic freedom, autonomy and international reputation that such recentralisation would bring under the NZQA. The North Island newspapers were more concerned with the NZQA's inflexible and simplistic standards that failed to cater for children with different abilities.

While newspapers held different views from one another, as well as from those held by academic and professional writers, they had, in keeping with the 
academic literature, serious reservations about the role and function of the NZQA.

Articles reporting on national test and exams were found to have drawn a sharp line between those in favour of such schemes. Usually members of the public were in favour of such schemes while those who were involved in education were not.

There were mixed reports about ERO's activities. One report written by a teacher was opposed to the standards set by ERO. The teacher described the standards as 'stultifying' and reflected academic and professional writers' opinions. The other two articles however, reported two schools in a favourable light for having, after years of difficulty in complying with the standards, finally made it.

North Island newspapers were also concerned with bulk funding and teachers salaries. Unions (administrative capture) received the most vitriolic reports while teachers (provider capture) less so. Teachers' salaries were frequently related to other concerns including, pay parity, performance, conditions of employment and shortages. Generally, but not exclusively, newspaper articles saw strikes as blocking educational progress in the 'new right' climate. One letter writer however, on balance, decided to support the teachers objecting to bulk finding. He trusted the teachers more than the government.

Publications on curriculum were evenly divided between the North and South Island newspapers with the exception of The Otago Daily Times, which had no publications on the topic. Newspapers were found to have a different emphasis than academic and professional writers on the curriculum changes, preferring to report on the content of the proposed changes. Changes to the social studies and the English programmes received diverse opinions in terms of quality and purpose. But the newer sunrise subjects that encompassed the new vocationalism based on busno-technocratic ideals, received favourable reports because they offered tangible careers and economic survival in the 'new right' economy. 
There was little reporting on minority and/or disadvantaged groups. Three articles were published on Maori, less on women, disadvantaged boys and Asian students. No articles with a Budd score of four or five were found on Pacific Islanders or other ethnic groups. No articles on special needs groups were found in the higher Budd score levels nor were they found in the literature review.

Also absent was the reporting on recentralisation brought about by the loss of agencies such as the Parents' Advocacy Council and the changed role of the school charters. However, newspapers did see the introduction of new administration offices from the central agencies, that is, NZQA and ERO, as a form of recentralisation and loss of democracy. Boards of trustees were seldom reported and newspapers did not focus on their role and responsibilities along with the conflict that had been found in the literature review (chapter three).

Academic and professional writers were also found to have contributed articles in newspapers and often they were the same writers as those found in the literature review (chapter three).

Overall, newspaper articles were found to have a narrow focus, not only in terms of themes, but also, within the theme itself. As expected newspapers reported on immediate, often contentious, day-to-day events in relation to their 'reader audience' by highlighting the implications such events would have to the wider community. Newspaper articles frequently, however, did not investigate into possible reasons behind the events. Similarly, newspapers did not trace ongoing issues and so the resolutions, if there were any, went unreported at the higher Budd score levels.

Of the 6,166 newspaper articles surveyed, 256 obtained a Budd scores of four or five. Of these, only 136 publications with a Budd score of four or five were found to have shared similar themes to academic and professional writers. The reasons for the similarities and differences between newspaper articles and those of academic and professional writers will be explored in the next chapter. 


\section{CHAPTER TEN - SUMMARY AND CONCLUSIONS}

\subsection{Introduction}

This thesis has been concerned with the role the media played during the educational period of radical policy reforms and posed two questions:

1. Did the newspapers reflect the same issues as the critiques of educational policy changes written by academic and professional groups?

2. Did the public receive from newspapers the kind of coverage and analysis that would help them realise the significance of the education policy changes taking place?

This final chapter will answer the two questions under the following headings:

- A brief overview of New Zealand newspapers since the 1980s

- Similar but not the same - provides a brief summary of the similarities and differences between academic and professional literature and newspaper articles

- Communication, complicated and complex theories - this section provides two theories on why such differences exist. The first is Habermas's critical analysis theory and the second is known as 'complexity' theory

- Summary, conclusions and recommendations

\subsection{A brief overview of New Zealand newspapers since the 1980s}

During the 1980s New Zealand media underwent a substantial change in ownership when newspapers changed from being New Zealand owned and operated businesses into the hands of two global media ownerships (see 4.1). As a result Kelsey (1999; see 4.2.1) estimated that 92 per cent of all New Zealand metropolitan and 81 per cent of provincial newspapers were foreign owned. Norris (2002; see 4.2.1) believed this had created a 'duopoly' dominated by two foreign companies - Independent Newspapers Limited (INL) whose ownership included The Evening Post, The Press and The Southland Times; and Wilson and Horton who owned The New Zealand 
Herald. Of the five major daily newspapers that this thesis surveyed only The Otago Daily Times was independently owned, by the New Zealand Allied Press.

Contrary to neo-liberal beliefs (see 4.2.1; 4.2 .3 and 4.3) that private ownership created competition and choice, critics saw the change of the media into foreign ownership as having a negative impact on New Zealand's cultural integrity, the loss of re-investment back into New Zealand, the risk of political interference, and a 'dumbing down' of news. Most importantly, through a series of interventions (gatekeeping), newspapers lost their important 'watchdog' role by being muzzled (see 4.2.1; 4.2.2; 4.3; 4.3.1; 4.4; 4.4.1 and 4.4.2). As a result newspapers were seen to be 'right wing', anti-competitive and anti-democratic. It was in this climate that the education reforms were reported (see 4.7).

\subsection{Similar but not the same}

The 136 newspaper articles surveyed in the previous two chapters, that is, those with a Budd score of four or five, frequently shared similar themes with academic and professional writers. However, within the shared themes differences were found and are summarised below under five subsections.

\subsubsection{Mirror Image}

Very few articles were found to have reflected the views of academic and professional literature in chapter three. Not surprisingly, those few newspaper articles that did, came from teachers and other educational professionals. In particular, concerns relating to bulk funding (Hearn, 1997; Cooney, 1997; see 9.2.1; Noonan, 1996; see 8.3.5) and assessment (Barrington, 1995; see 9.3.2.3; Bennett, 1997; see 9.3.2.2) are such examples. Academic writers appearing in newspapers, such as Gould (1996; see 8.3.2), repeated almost verbatim the same concerns that had been identified in the academic and professional literature (see 3.3.3). While these examples were the closest to the academic literature they represented only 0.6 per cent of all expert comments (see Table 6.3.2) and therefore can be said to have little voice. The remaining articles will 
be discussed in order of shared similarities to those in the academic and professional literature review in chapter three.

\subsubsection{Content Focus and Tone}

The financial viability of all educational institutions was of deep concern to academic and professional literature (see 3.3). However, newspaper articles largely narrowed their focus to tertiary education and, in particular, the economic viability of the universities to survive the changes of the education reforms under neo-liberalism. Their possible failures, especially Otago University's possible failure, to survive were seen to have dire consequences for those regions (see 8.3.1). Thus the focus was on the impact to the wider community rather than on the loss of the 'entrepot' function (Boston, 1990; see 3.3.3) and 'critic and conscience' role (Gould, 1999; see 3.3.3) that universities had traditionally held. In comparison, universities were concerned with maintaining their traditional role under neo-liberalism (see 3.3.3).

In sharp contrast, newspaper articles paid scant attention to the economic plight of primary and secondary schools. A few articles, particularly from The Press (see 8.3.4), were supportive toward creating a two-way process between the newspaper and the reader audience by highlighting the inequality of opportunity to achieving a decent education under the 'new right' policies. Furthermore, the newspaper vowed to politicise those issues during the forthcoming general election campaign.

Student funding (see 8.3.3) and teachers' salaries and employment conditions, especially unions (see 9.2.2), received little sympathetic or empathetic reporting from newspapers while, on the other hand, commercial enterprise (see 8.3.6.1) and the new vocational subjects (see 9.3.1.3) received positive reports.

\subsubsection{Concepts}

Divergent and contradictory views on concepts such as equality of opportunity or choice, especially in accessing schools (see 9.4), highlighted the difficulty of what was meant by such terms and the problems of implementing them. The 
often flawed, articles not only varied among themselves in how to achieve such concepts, but were also at variance with academic and professional writers in their rationale for choosing them (see 3.3.4 and 3.4.1).

\subsubsection{Under-reported Themes}

In addition to the newspaper articles' narrow band of shared themes that revealed a different emphasis, tone or concept were areas that were largely under-reported. Several groups that fall in this category have already been acknowledged in the previous chapter. Such groups included Maori, Pacific Island groups, women and disadvantaged boys (see 9.5). There were, however, other themes that also come into this category. Examples of under-reporting included early childhood education (see 8.3.5), primary and secondary schools (see 8.3.4), the management of schools by boards of trustees (see 8.3.4) and the disappearances of the Parents’ Advocacy Board and Community Education Forums (see 8.2).

\subsubsection{Omissions}

Omissions from reporting included the lack of investigative journalism into the underlying reasons behind the issues that academic and professional writers had identified as persistent and emerging issues arising from and during the 1988-1999 period (the period covered by this thesis). Such themes included issues behind teachers' salaries and employment conditions (see 3.5), performance and assessment (see 3.5.1; 3.6; 3.6.1; 3.6.3; 3.6.4 and 3.6.5). Other issues included the long-term effect that student debt had on students' relationships, not only with their immediate family, but also in terms of longer relationships with the country as a whole (see 3.3.3).

Editorials also provided an opportunity to influence the reader audience, especially the 'A' readers (see 4.5.1). The content of four editorials published by The Press and The Otago Daily Times highlighted the problem of implementing parental choice, based on egalitarian principles, when accessing a school of choice (see 9.4). The remaining two articles were critical of 'irresponsible' parents under neo-liberalism (see 8.2) and scathing about teachers' strikes (see 9.2.1). However, the editorial 'voice' in this study 
represented 0.1 per cent of the total Budd score (see Table 6.3.2) and therefore, in terms of influence, can only be described as a faint whisper.

Further loss of voice was demonstrated with a total of only 19 letters to the editor of the surveyed newspapers. All 19 letters had a Budd score of four and represented 0.3 per cent of the total letter count (see Table 6.3.2). Letters could have provided one of the few opportunities for the reader audience to participate, particularly with the use of e-mails that would have increased ease of access. Such a poor response would suggest that while the reader audience was aware of the administrative changes their response was one of little interest.

Resolutions related to reconciling different points of view or long term problems frequently 'faded' from prominence in newspapers. The concept of equality for minority groups to access university education (see 8.3.1) or the resolutions to student funding (see 8.3.3) are such examples.

Finally, although some articles reported on the attempts of recentralisation, for example, the role and ownership of universities (see 8.3.2), and the attempt by the NZQA to control and standardise the universities' qualification system (see 9.3.2.1), there were also more covert and insidious attempts at recentralisation. Such covert reporting would reach only an alert and well-informed discerning reader audience. Such an example was in the loss of teachers' professional autonomy (see 3.5.1). As a result, not only was there no 'voice' but an accompanying ‘invisibility’.

\subsubsection{Differences within Newspapers}

Some differences were found between the North and South Islands. The South Island newspapers were concerned with the economic survival of the tertiary institutions (see 8.3.1) as well as ownership of them (see 8.3.2), commercial enterprise (see 8.3.6) and access to schools (see 9.4). Both North and South Island newspapers reported on the role of the NZQA but differed in focus (see 9.3.2.1 and 9.3.2.2). North Island newspapers were found to have reported more on the Picot Report (see 8.2), teachers' salaries and conditions (see 9.2.2) 
and changes to the content and format of assessments and qualifications framework (see 9.3.2.2).

Such differences may be due to the South Island holding firm opinions about equality of opportunity while experiencing considerably more economic hardship under the neo-liberal reforms than their North Island counterparts. The North Island newspapers, being closer to the policy makers and the seat of government, were more likely to report on the day-to-day responses to the policy reforms per se.

Although four of the five major daily newspapers surveyed were foreign owned (see 4.2.1) no division was found between ownership of one paper to its other rivals. This may have been due to the competitive nature of the industry, which kept one another in check. The result was considerable homogeneity of consensual newspaper articles bordering on 'pack journalism’ (see 4.4.1).

\subsubsection{The Wider Context}

In all 6,166 articles were found on education during the period under review. The previous section summarised the 136 articles that shared similar themes with the academic and professional literature review in chapter three. Those 136 articles represented 2.2 per cent of the 6,166 articles surveyed and therefore represent a comparatively very low count. The remaining 120 articles with a high Budd score and the 5,910 articles in the 1-3 Budd score range reported on student, administration and institution story contents (see 6.3.1 and 6.3.3). Although it is beyond the scope of this thesis to examine those topics (which also require further research) they do provide a further indication, in terms of selectivity (gatekeeping), what newspapers considered to be newsworthy.

The student story content focused very much on 'human interest' stories such as health, socials or ceremonies (see Appendices, Tables A.7.1-A.7.14). Such articles were not conflict-laden and fell into the 'cootchie-coo' news category that Edwards described (2002; see 4.3). By focusing on such non-conflict laden local human-interest stories, the serious and often contentious issues 
about education were ignored. As a consequence the news compromised the 'watchdog' role newspapers claimed to have upheld. The following section will discuss some of the reasons why this happens.

\subsection{Communication and Complexity Theory}

Habermas's 'public sphere' (1989; see 4.3) believes that communication systems should contribute in two ways. First, they should provide access to information, advice, and analysis that would enable citizens to know their rights and to pursue them effectively. Second, they should provide the broadest possible range of information, interpretation and debate. This would enable citizens to exercise their choice to register dissent and to propose alternatives. In turn, the two-way process would enable citizens to form rational opinions and become emancipated within a democratic society. The results of this thesis have shown that newspapers have failed to meet with Habermas's concept of an ideal communication system.

Failure to meet Habermas's ideal may be explained to some extent by the use of 'complexity' theory. Davis et al (2000) describe education and other systems as being either 'complicated' or 'complex' in nature. The former in some sense models mechanical systems such as clocks, cars and refrigerators. For example, if a breakdown occurs, the faulty link or part is located and replaced, and the system is reassembled. In effect, the whole is seen as being the sum of the parts. Complicated systems are, according to Davis et al (2000:55), characterised by the:

Predictable sums of their parts...Their behaviours are planned, directed and determined by their architecture... These sorts of objects are intended to fulfil specific functions and they operate according to a deliberate design.

Within learning theory, for example, behaviourist approaches to teaching and education largely fit with a 'complicated' view of life. This is because the theory espouses the notion that the correct application of reinforcement and punishment schedules will result directly in the desired behaviour. Learning is 
'complicated' but able to be analysed into its component parts and then modelled for the design of instruction.

However, in reality Davis et al (2000) see human learning and cognition as belonging to 'Complex systems'. Unlike 'complicated' systems, 'complexity' recognises that behaviour, learning, professional judgement and other 'complex' processes, are not always able to be broken down into constituent components and then reassembled to achieve the 'whole'. This is captured in the notion of 'tacit' knowledge, where a professional faced with a problem is able to come up with a solution without being able to describe precisely the processes involved. The professional, in effect, draws upon not only knowledge of the subject but also professional knowledge, and work and life experiences in such a way that the solution is a melding of many things, often spontaneous, that creates a 'unique' whole. In effect, the whole is not only more than the sum of the parts, it recognises that the parts are not easy to identify and link in a precise way. Davis et al (2000:78) contend that Complex theories are:

Not about acquiring and accumulating information. Rather, learning is principally a matter of keeping pace with one’s evolving circumstances...Knowledge is contingent, contextual and evolving; never absolute, universal or fixed.

The point being made is that academic and professional literature recognises and deals with issues of the day through a 'complexity' lens, which recognises the need to see relationships and problems within the framework of 'context'. In sharp contrast, newspapers see their role in a way that is more with 'complimentedness'. Newspapers try to reduce the problems and issues of education to a level that is readily comprehensible to the 'reader audience' and with an immediacy that captures their attention. These are two very significant elements that underpin the commercial viability of the media. In operating this way, newspapers in effect, place a higher priority on commercial viability than the main purposes that Habermas sees as the communication role of newspapers: access to information, advice, analysis, interpretation, and debate, 
which, in turn, enables a citizen to form rational opinions and to become emancipated within a democratic society. Thus, by reprioritising their goals to remain commercially viable, newspapers compromise the goals that Habermas considers paramount to achieving a truly democratic communication system.

\subsubsection{The Watchdog Role}

Academic and professional writers and newspaper reporters see themselves as having a watchdog role and jealously guard their freedom to exercise it. Both see it as their role to inform their respective reader audiences' to relevant issues as part of maintaining an emancipated and democratic society. There are however, some significant differences (see Table 10.4 for summary).

Table 10.4: Summary of the Similarities and Differences between Academic and Professional Literature and Newspaper Articles.

\begin{tabular}{|c|c|c|}
\hline & $\begin{array}{l}\text { Academic and Professional } \\
\text { Literature }\end{array}$ & Newspaper Articles \\
\hline Role & $\begin{array}{l}\text { Watchdog - Entrepot; Critic } \\
\text { and Conscience of Society }\end{array}$ & $\begin{array}{l}\text { Watchdog role - muzzled, } \\
\text { 'dumbed-down' }\end{array}$ \\
\hline Writers & Well educated; Phronesis & $\begin{array}{l}\text { Quality variable, influenced } \\
\text { by Gatekeepers }\end{array}$ \\
\hline Content & $\begin{array}{l}\text { Complex, analytical, } \\
\text { investigative, reflective }\end{array}$ & $\begin{array}{l}\text { Superficial, descriptive, non- } \\
\text { specialised,'Human-interest' } \\
\text { sensational, non-conflicting, } \\
\text { local }\end{array}$ \\
\hline Audience & $\begin{array}{l}\text { Well educated, highly } \\
\text { interested in Education }\end{array}$ & $\begin{array}{l}\text { General public, less-well } \\
\text { educated, less interested }\end{array}$ \\
\hline Time & To research complex issues & $\begin{array}{l}\text { Little time to reflect, analyse } \\
\text { or investigate }\end{array}$ \\
\hline Principles & $\begin{array}{l}\text { Egalitarian, emancipatory, } \\
\text { democratic }\end{array}$ & $\begin{array}{l}\text { Cultural bricolage, anti- } \\
\text { democratic }\end{array}$ \\
\hline Ideology & Generally 'left wing' & Generally 'right wing' \\
\hline
\end{tabular}


Academic and professional writers have been specifically educated over a lengthy period of time to a considerable depth and complexity within their discipline. They have developed professional wisdom, 'phronesis' (Humphreys and Hyland, 2002:7) from their formal professional education as well as their professional practical experiences. They have more time to research and to reflect on their topic. Their concerns relate to issues arising within their discipline and they see their role as contributing to the 'entrepot' (see 3.3.3) function and their role as being 'critic and conscience' of society (see 3.3.3). Academic and professional writers in education support egalitarianism and could be best described as mostly 'left wing' (see 3.5.1).

In contrast, newspapers could be described as neo-liberal (see 4.2.3). Furthermore, while there are mixed views on the quality of journalists' education (see 4.4.1), generally they are considered to be less well educated when compared to academic and professional writers. Regardless of their education, journalists are constrained by influences beyond their control in what they write for their newspaper (see 4.4.1). Newspapers aim to attract a reader audience from the public, which is considered to be less educated and less interested in issues on education. Journalists have little time to reflect, analyse or investigate issues because of the pressure they are under to report on immediate news topics. The news topics have to serve a dual function of not only satisfying their reader audience but also the topics need to be commercially viable to sustain their industry. Therefore, they have little time to delve into complex issues that academic and professional writers pursue. As a result complex issues, such as those raised in the literature review in this thesis, are selected (gatekept) out or are weakened to 'simplify' or 'objectify' issues for easy assimilation by the readers.

To help fulfil the dual functions of attracting a reader audience in order to remain commercially viable, newspapers often place local, sensational, highly descriptive, human-interest, eye grabbing stories on the top half of the front page. This gives such news items a high Budd score, thus indicating they are highly newsworthy. In comparison, the 6,166 articles surveyed in this research were found to be overwhelmingly unsensational with a low Budd score (see 
Table 6.3.2). Such articles are the bread and butter of newspapers. To be too provoking or contentious would run the risk of offending the reader audience and in turn compromise the commercial viability. By adopting a 'dumbed down' stance (see 4.3) newspapers avoid addressing the serious educational problems academic and professional writers have raised, especially in maintaining an egalitarian educational system. They treat as 'complicated' only, those things that are 'complex'. Thus, the newspapers' role of watchdog has become muzzled resulting in a 'cultural bricolage' (Srebreny, 2000; see 4.2.3) that has led to an unequal power distribution that, based on the evidence of the literature and the Budd score analysis in this thesis, is arguably antisocial, anti-Maori, anti-feminist, anti-competitive and therefore antidemocratic.

\subsection{Summary, Conclusions and Recommendations}

This thesis found that during the education reform years of 1988-1999, the newspaper articles surveyed from the five major daily New Zealand newspapers shared, in a narrow range of topics, similar themes with those of academic and professional writers. However, the content was, with a few exceptions, qualitatively different from those in academic and professional literature. Newspaper articles were found to have become simplified, personalised, decontextualised rather than addressing complex and contentious educational issues. Thus, in the new global media market of the commodification of information, educational articles were generally found to be superficial, narrow, unquestioning and given low prominence.

Further research is required into the remaining Budd score four and five topics on student, administration and institution story contents, and, in particular, their story subcontents. As noted in chapter eight, the detailed analysis of articles with Budd scores four and five was limited to those that related to the topics or themes identified in the literature review (that is, themes focussed on by academic and professional writers). Also, further research is needed into the contributions from editorials, expert comments and letters to the editor from all Budd score ranges from all five major daily newspapers. Finally, more research is required on the articles published about minority groups. Until these story 
contents and their substory contents have been examined and their findings revealed, will a full understanding be possible about the range of educational themes covered by newspapers.

At present, the reader audience, while being aware of some of the issues that were raised during the education reform years, can only be said to have had a narrow and superficial exposure to the complexity of such issues. A further loss of voice as expressed through the letters to the editor suggests that while the reader audiences were aware of educational issues, their responses, as measured in newspapers, was one of little interest. Therefore, Habermas's ideal of having a communication system providing a dual role, which enables the public to form rational opinions and in turn become emancipated within a democratic society, has been severely compromised. 


\section{BIBLIOGRAPHY}

Alton-Lee, A. and Praat, A. (2000). Explaining and Addressing Gender Differences in the Compulsory Education Sector (1989-1999): A Literature Review. Wellington: Commissioned by The Ministry of Education.

Apple, M. (1982). Cultural and Economic Reproduction in Education. London, Boston and Henley: Routledge and Kegan Paul.

Apple, M. (2001). Educating the "Right" Way. New York: Routlledge Falmer.

Barrington, J. (1990). Historical factors for Change in Education. In McKinlay, P. (Ed.), Redistribution of Power? Devolution in New Zealand (pp.191-213). Wellington: Victoria University Press.

Barrington, J. (1991). Educational Reform in New Zealand. In Ginsberg, M. (Ed.), Understanding Educational Reform in Global Context: Economy, Ideology and the State (pp. 285-310). New York and London: Garland Publishing Inc.

Barrington, J. (1998). Central and Local Control in Education. New Zealand Annual Review of Education, 7: 1997.

Bassett, M. (2002). Balancing the Fourth Estate. The Dominion Post, (August 20: B4). Wellington.

Beeby, C. E. (1992). Biography of an Idea: Beeby on Education. Wellington: New Zealand Council for Educational Research.

Bernstein, R. (1985). Habermas and Modernity. Oxford: Polity Press.

Benton, R. (1992). Biculturalism in Education: Policy and Practice under the Fourth Labour Government. In Holland, M. and Boston, J. (Eds.), The Fourth Labour Government: Politics and Policy in New Zealand (pp.192-212). Auckland: Oxford University Press.

Boston, J. and Holland, M. (1987). The Fourth Labour Government: Radical Politics in New Zealand. Oxford: Oxford University Press.

Boston, J. (1990). The Funding of Tertiary Education. In Middleton, S., Codd, J. and Jones, A. (Eds.), New Zealand Education Policy Today: Critical Perspectives (pp. 161-177). Wellington: Allen and Unwin.

Boston, J., Martin J., Pallot, J. and Walsh, P. (Eds.), (1991). Reshaping the State: New Zealand's Bureaucratic Revolution. Auckland: Oxford University Press. 
Boston, J. and Dalziel, P. (1992). A Decent Society? In Boston, J. and Dalziel, P. (Eds.), The Decent Society? Essays in Response to National's Economic and Social Policies (pp.186-209). Auckland: Oxford University Press.

Boston, J. (1999). New Zealand's Welfare State in Transition. In Boston, J., Dalzeil, P. and St. John, S. (Eds.), Redesigning The Welfare State in New Zealand: Problems, Policies, Prospects (pp. 3-19). Oxford: Oxford University Press.

Bourdieu, P. (1973). Cultural Reproduction and Social Reproduction. In Brown, R. (Ed.), Contemporary Research in Sociology of Education. London: Tavistock.

Bowers, D. (1988). Education Reforms in the 1980s: the Media, Public Opinion, and elite Policy-Making. Unpublished Ph.D., University of Texas, Austin, Texas.

Boyd, R. (1997). Change in National Administration Post-Picot. Unpublished Master of Educational Administration, Massey, Palmerston North.

Boyd-Bell, S. (2001, July 15). Mediawatch (R. Brown, Director). Wellington: National Radio.

Budd, R. W. (1964). Attention Score: A Device for Measuring Newsplay. Journalism Quarterly, 41, 259-262.

Butterworth, G. and Butterworth, S. (1998). Reforming Education: The New Zealand Experience 1984-1996. Palmerston North: The Dunmore Press Ltd.

Campbell, R. (2002, July 20). The War on Terrorism and other Myths. Listener, 60.

Cleveland, L. (1971). The Subject Content of New Zealand Press. Unpublished Ph.D., Victoria University, Wellington.

Codd, J., Harker, R. and Nash, R. (1990). Introduction: Education, Politics and Economic Crisis. In Codd, J., Harker, R. and Nash, R. (Eds.), Political Issues in New Zealand Education (pp.7-21). Palmerston North: The Dunmore Press Ltd.

Codd, J. (1990a). Managerialism: The Problem with Today's Schools. Delta, 44, 17-24.

Codd, J. (1990b). Educational Policy and the State. In Middleton, S., Codd, J. and Jones, A. (Eds.), New Zealand Education Policy Today (pp.191-205). Wellington: Allen and Unwin. 
Codd, J. and Gordon, L. (1991). School Charters: The contractualist state and education policy. New Zealand Journal of Educational Studies, 26 (1), 21-24.

Codd, J. (1993). Equality and choice: The paradox of New Zealand education reform. Curriculum Studies, 1(1), 75-90.

Codd, J. (1994). Educational Reform and the Contradictory Discourses of Evaluation. Evaluation and Research in Education, 8 (Nos. 1\&2).

Codd, J., McAlpine, D. and Poskitt, J. (1995). Assessment Policies in New Zealand: Educational Reform or Political Agenda? In Peddie, R. and Tuck, B. (Eds.), Setting the Standards: Competence in National Qualifications (pp.32-58). Palmerston North: The Dunmore Press Ltd.

Codd, J. (1997). Knowledge, Qualifications and Higher Education. In Olssen, M. and Morris Matthews, K. (Eds.), Education Policy in New Zealand: The 1990s and Beyond (pp.130-144). Palmerston North: The Dunmore Press Ltd.

Codd, J. (1999). Educational Reform, Accountability and the Culture of Distrust. In Thrupp, M. (Ed.), A Decade of Reform in New Zealand: Where to now? (pp. 45-53). Waikato: Waikato University.

Cohen, L., Manion, L. and Morrison, K. (2000). Research Methods in Education (5th ed.). London and New York: Routledge/Falmer.

Comrie, M. (2002). Spin in the News. In McGregor, J. and Comrie, M. (Eds.), What's News? Reclaiming Journalism in New Zealand (pp.158172). Palmerston North: The Dunmore Press Ltd.

Coxon, E. and Mara, D. (2000). Education Policy for Pacific Nation Peoples. In Marshall, J., Coxon, E., Jenkins, K. and Jones, A. (Eds.), Politics, Policy, Pedagogy: Education in Aotearoa/New Zealand (pp.157-186). Palmerston North: The Dunmore Press Ltd.

Creswell, J. W. (2003). Research Design: Qualitative, Quantitative, and Mixed Methods Approaches (2nd. ed.). London: Sage.

Curran, J. and Seaton, J. (Eds.), (1988). Power Without Responsibility: the Press and Broadcasting in Britain. London and New York: Routledge.

Curran, J. and Gurevitch, M. (Eds.), (2000). Mass Media and Society. London: Arnold.

Curran, J. (2000). Rethinking Media and Democracy. In Curran, J. and Gurevitch, M. (Eds.), Mass Media and Society (pp.120-154). London: Arnold. 
Dahlgren, P. (2000). Media, Citizenship and Civic Culture. In Curran, J. and Gurevitch, M. (Eds.), Mass Media and Society (pp. 310-328). London: Arnold.

Dale, R. and Ozga, J. (1993). Two Hemispheres - Both New Right? 1980s Education Reform in New Zealand, England and Wales. In Lingard, B., Knight, P. and Porter, P. (Eds.), Schooling Reform in Hard Times (pp. 63-87). London: The Falmer Press.

Dale, R. (2000). Social Class and Education in Aotearoa/New Zealand. In Marshall, J., Coxon, E., Jenkins, K. and Jones, A. (Eds.), Politics, Policy, Pedagogy: Education in Aotearoa/New Zealand (pp.107-137). Palmerston North: The Dunmore Press Ltd.

Davis, B., Sumara, D. and Kuce-Kapur, R. (2000). Emerging Minds: Learning and Teaching in a Complex World. New York: Mahwah: Lawrence Erlbaum Associates.

Douglas, R. (1987). Toward Prosperity. Auckland: David Bateman.

Easton, B. (1997). The Commercialisation of New Zealand. Auckland: Auckland University Press.

Easton, B. (1999). The Whimpering of the State: Policy after MMP. Auckland: Auckland University Press.

Edwards, B. (2002). The Cootchie Coo News Revisited. In McGregor, J. and Comrie, M. (Eds.), What's News? Reclaiming Journalism in New Zealand (pp.16-32). Palmerston North: The Dunmore Press Ltd.

Elley, W. B. (1996). Curriculum Reform: forwards or backwards? Delta, 48 (1), 11-18.

Epstein, R. (1999). Regulatory Reform in Schooling. Wellington: New Zealand Business Roundtable.

Fitzsimons, P., Peters, M. and Roberts, P. (1999). Economics and Educational Policy Process in New Zealand. In Thrupp, M. (Ed.), A Decade of Reform in New Zealand: Where to now? (pp. 35-44). Waikato: Waikato University.

Frith, S. (2000). Entertainment. In Curran, J. and Gurevitch, M. (Eds.), Mass Media and Society (pp. 201-217). London: Arnold.

Fox, J. (2001). Postmodern Encounters: Chomsky and Globalisation. Cambridge: Icon Books.

Gans, H. (1979). Deciding What's News. New York: Pantheon Books. 
Geiber, W. (1964). News is what Newspapers make it. Communicator and His Audience, Political Science Dept. paper reprint 1984, 173-177.

Golding, P. and Murdock, G. (2000). Culture, Communications and Political Economy. In Curran, J. and Gurevitch, M. (Eds.), Mass Media and Society (pp.70-92). (3rd ed.). London: Arnold.

Gorard, S. and Fitz, J. (1998). Under Starters Orders. International Studies in Sociology of Education, 8 (3).

Gordon, L. (1993). From Professional to Proletarian: teachers and the state in Aotearoa. Delta, 47, 33-45.

Gould, B. (1999). The Future of New Zealand Universities. In Thrupp, M. (Ed.), A Decade of Reform: Where to now? (pp. 28-33). Waikato: University of Waikato.

Grace, G. (1992). Labour and Education: The Crisis and Settlements of Education Policy. In Holland, M. and Boston, J. (Eds.), The Fourth Labour Government: Politics and Policy in New Zealand (pp.165-191). (2nd ed.). Auckland: Oxford University Press.

Habermas, J. (1975). Legitimation Crisis (T. McCarthy, Trans.). Boston: Beacon Press.

Habermas, J. (1984). The Theory of Communicative Action: Reason and The Rationalization of Society (T. McCarthy, Trans. Vol. 1). London: Heinemann.

Habermas, J. (1987). The Theory of Communicative Action: Lifeworld and System: A Critique of Functionalist Reason (T. McCarthy, Trans.). Oxford: Polity Press.

Habermas, J. (1989). The Structural Transformation of the Public Sphere. Cambridge: Polity.

Habermas, J. (1992). Further Reflections on the Public Sphere. In Calhoun, C. (Ed.), Habermas and the Public Sphere (pp.421-461). Cambridge, MA: MIT Press.

Habermas, J. (1996). Between Facts and Norms. Cambridge: Polity.

Hall, C. (1994). Nga Taumata Matauranga O Aotearoa: Higher education in New Zealand: Obstacles to the Integration of University Qualifications and Courses into the National Qualifications Framework (Occasional Paper Number 1). Wellington: University of Victoria. 
Hall, C. (1995). University Qualifications and the New Zealand National Qualifications Framework: Obstacles and a Way Forward. In Peddie, R. and Tuck, B. (Eds.), Setting the Standards: The Assessment of Competence in National qualifications (pp.154-176). Palmerston North: The Dunmore Press Ltd.

Hall, C. (2003). The Normative (Quantitative) and Interpretive (Qualitative) Research: Lecture Notes. Wellington: Victoria University.

Hall, C. (2003a). Constructing Research Tools. Lecture Notes. Wellington. Victoria University.

Harbridge, R. (1983). The treatment of Industrial Relations in three major News Zealand papers. New Zealand Journal of Industrial Relations, 8, 11-21.

Harold, S., Hawkesworth, L., Mansell, H. and Thrupp, M. (1999). A Decade of Change and Continuity: Emerging Themes from the Front Line of School Reform. In Thrupp, M. (Ed.), A Decade of Reform in New Zealand: Where to now? (pp. 234-246). Waikato: Waikato University.

Herman, E. and Chomsky, N. (1988). Manufacturing Consent. New York: Pantheon.

Holland, M. and Boston, J. (Eds.), (1992). The Fourth Labour Government: Politics and Policy in New Zealand (2nd ed.). Auckland: Oxford University Press.

Hughes, D. and Pearce, D. (2003). Secondary School Decile Ratings and Participation in Tertiary Education. New Zealand Journal of Educational Studies, 38 (2), 193-206.

Humphreys, M. and Hyland, T. (2002). Theory, Practice and Performance in Teaching: professionalism, intuition and jazz. Educational Studies, 28 (1), 5-15.

Irwin, K. (1999). Maori Education Policy 1989-1998: Lampooning it up! In Thrupp, M. (Ed.), A Decade of Reform in New Zealand: Where to now? (pp. 66-76). Waikato: Waikato University.

Irwin, M. (1999). A Decade of Curricular Reform. In Thrupp, M. (Ed.), A Decade of Reforms in New Zealand: Where to now? (pp.156-166). Waikato: Waikato University.

James, C. (1986). The Quiet Revolution. Wellington: Allen and Unwin/Port Nicholson Press.

James, C. (1992). New Territory: The transformation of New Zealand 1984-1992. Wellington: Bridget Williams Books. 
Jenkins, K. and Jones, A. (2000). Maori Education: A State of Promise. In Marshall, J., Coxon, E., Jenkins, K. and Jones, A. (Eds.), Politics, Policy, Pedagogy Education in Aotearoa/New Zealand (pp. 139-154). Palmerston North: The Dunmore Press Ltd.

Jesson, B. (1987). Behind the Mirrored Glass. Auckland: Penguin Books.

Johnston, P. (1997). A Fair measure of Influence? Maori members on School Boards of Trustees. Unpublished M.A., Auckland University, Auckland.

Johnston, P. (1998). he ao rereke; Education policy and Maori underachievement. Unpublished Ph.D., Auckland University, Auckland.

Johnston, P. (1999). In Through the Out Door: Policy Developments and Processes for Maori. New Zealand Journal of Educational Studies, 34 (1).

Jones, A. (2000). Gender Matters in Schooling in Aotearoa/New Zealand. In Marshall, J., Coxon, E., Jenkins, K. and Jones, A. (Eds.), Politics, Policy, Pedagogy: Education in Aotearoa/New Zealand (pp. 71105). Palmerston North: The Dunmore Press Ltd.

Keats, R. (1981). The Politics of Social Theory. Oxford: Basil Blackwell.

Kelsey, J. (1999). Reclaiming the Future: New Zealand and the Global Economy. Wellington: Bridget Williams Books.

Kim, H. C. (1989). Education and the Daily Press in the State of Connecticut. Unpublished Ph.D., University of Connecticut, Connecticut.

Kovach, B. and Rosenstiel, T. (1999). Warp Speed: America in the age of mixed media. New York: Century Foundation Press.

Lange, D. (1994). Cuttings. Wellington: Jonathon Hudson and Associates.

Lauder, H., Hughes, D., Watson, S., Simiyu, I. et al. (1995). Trading in Futures: Why markets in New Zealand don't work. The Smithfield Project, phase one (Third report to the Ministry of Education). Wellington: Ministry of Education.

Lauder, H., Hughes, D. and Watson, S. (1999). The Introduction of Educational Markets in New Zealand: Questions and Consequences. In Thrupp, M. (Ed.), A Decade of Reform in New Zealand: Where to now? (pp. 86-98). Waikato: Waikato University. 
Lauder, H. (1994). The Creation of market competition for education in New Zealand: An empirical analysis of a secondary school market. Wellington: Ministry of Education.

Lewin, K. (1984). Channels of Group Life. Human Relations, Reprinted in VUW Political Sciences Dept paper. 1984, Vol 1. No. 2.

Lichtenberg, J. (2000). In Defence of Objectivity Revisited. In Curran, J. and Gurevitch, M. (Eds.), Mass Media and Society (pp. 238-254). London: Arnold.

Lichter, R., Rothman, S. and Lichter, S. (1986). The Media Elite. USA: Adler and Adler.

Lingard, B., Knight, J. and Porter, P. (1993). Schooling Reform in Hard Times. London: The Falmer Press.

Marshall, J. (1997). The New Vocationalism. In Olssen, M. and Morris Matthews, K. (Eds.), Education Policy in New Zealand: The 1990s and Beyond (pp. 304-326). Palmerston North: The Dunmore Press Ltd.

Marshall, J., Coxon, E., Jenkins, K. and Jones, A. (2000). Politics, Policy Pedagogy: Education in Aotearoa/New Zealand. Palmerston North: The Dunmore Press Ltd.

May, H. (1990). Growth and Change in the Early Childhood Services: A Story of Political Conservatism, Growth and Constraint. In Middleton, S., Codd, J. and Jones, A. (Eds.), New Zealand Educational Policy Today (pp. 94-109). Wellington: Allen and Unwin.

May, H. (1998). The Discovery of Early Childhood (2nd ed.). Auckland: University of Auckland with Bridget Williams Books.

May, H. (1999). The Price of Partnership: The Before Five decade. In Thrupp, M. (Ed.), A Decade of Reform in New Zealand: Where to now? (pp. 18-27). Waikato: University of Waikato.

McGregor, J. (2002). Changing Patterns. In McGregor, J. and Comrie, M. (Eds.), What's News? Reclaiming Journalism in New Zealand (pp. 13-15). Palmerston North: The Dunmore Press Ltd.

McKenzie, D. (1997). The Cult of Efficiency and Miseducation: Issues of Assessment in New Zealand. In Olssen, M. and Morris Matthews, K. (Eds.), Education Policy in New Zealand: The 1990s and Beyond (pp. 47-64). Palmerston North: The Dunmore Press Ltd.

Merriam, S. B. (1998). Qualitative Research and Case Study application in education. San Francisco: Jossey-Bass. 
Morrison, A. (2002). Objectivity. In McGregor, J. and Comrie, M. (Eds.), What's News? Reclaiming Journalism in New Zealand (pp. 56-71). Palmerston North: The Dunmore Press Ltd.

Nash, R. (1989). Tomorrow's Schools: State power and parent participation. New Zealand Journal of Educational Studies, 24 (2), 113138.

Newbold, C., Boyd-Barrett, O. and Van der Bulck, H. (Eds.), (2002). The Media Book. London: Arnold.

New Zealand Official Yearbook 2000 (2000). (102 ed.). Wellington: David Bateman.

Norris, P. (2002). News Media Ownership in New Zealand. In McGregor, J. and Comrie, M. (Eds.), What's News? Reclaiming Journalism in New Zealand (pp. 33-55). Palmerston North: The Dunmore Press Ltd.

Offe, C. (1984). Contradictions of the Welfare State (J. Keane, Trans.). London: Hutchinson.

Olssen, M. and Morris Matthews, K. (1997). Education Policy in New Zealand: The 1990 s and Beyond. Palmerston North: The Dunmore Press Ltd.

Pankhurst, T. (2001, July 15). Mediawatch (R. Brown, Director). Wellington: National Radio.

Parenti, M. (1986). Inventing Reality: the Politics of the Mass Media. New York: St Martin's Press.

Perigo, L. (2002, October 13). Mediawatch (R. Brown, Director). Wellington: National Radio.

Peters, M. and Marshall, J. (1996). Individualism and Community: Education and Social Policy in the Postmodern Condition. London: The Falmer Press.

Peters, M. (1997). Neo-liberalism, Privatisation and the University in New Zealand: The Democratic Alternative. In Olssen, M. and Morris Matthews, K. (Eds.), Education Policy in New Zealand: The 1990s and Beyond (pp. 228-249). Palmerston North: The Dunmore Press Ltd.

Peters, M., Marshall, J. and Massey, L. (1994). Recent Educational Reforms in Aotearoa. In E. Coxon, Jenkins, K., Marshall, J. and Massey, L. (Ed.), The Politics of Learning and Teaching in AotearoaNew Zealand (pp. 251-272). Palmerston North: Dunmore Press. 
Peters, M. A., Peters, C. and Freeman-Moir, J. (1992). The 1991 Budget and Tertiary Education: Promises, Promises. Wellington. Victoria University.

Philips, D. (2000). Curriculum and Assessment policy in New Zealand: ten years of reforms. Educational Review, 52 (2).

Pihama, L. (1997). Policy Constructions: In Whose Interest? A Critical Analysis of Parents as First Teachers in Relation to Maori Education. In Olssen, M. and Morris Matthews, K. (Eds.), Education Policy in New Zealand: The 1990s and Beyond (pp. 283-303). Palmerston North. The Dunmore Press Ltd.

Ramsay, P. (1993). Picot - Vision and Reality in New Zealand Schools: An Insider's View. In Lingard, B., Knight, J. and Porter, P. (Eds.), Schooling Reform in Hard Times (261-283). London: The Falmer Press.

Regus, K. and Roman-Velaquez, P. (2000). Globalization and Cultural Identities. In Curran, J. and Gurevitch, M. (Eds.), Mass Media and Society (pp. 329-345). London: Arnold.

Riddell, O. (2002). A Gallery of Rogues? In McGregor, J. and Comrie, M. (Eds.), What's News? Reclaiming Journalism in New Zealand (pp. 199-209). Palmerston North: The Dunmore Press Ltd.

Roberts, P. (1997). A Critique of the NZQA Policy Reforms. In Olssen, M. and Morris Matthews, K. (Eds.), Education Policy in New Zealand: The 1990s and Beyond (pp. 162-190). Palmerston North: The Dunmore Press Ltd.

Roulston, D. (1986). An Historical Study of Newspapers and Public Opinion about Education. Unpublished M.A., Victoria University, Wellington.

Schudson, M. (2000). The Sociology of News Production Revisited (Again). In Curran, J. and Gurevitch, M. (Eds.), Mass Media and Society (pp.175-200). London: Arnold.

Schudson, M. (2001). The Objectivity Norm in American Journalism. Journalism, 2 (2), 149-177.

Seidman, S. E. (1989). Jurgen Habermas on Society and Politics - a reader. Boston: Beacon Press.

Sexton, S. (1990). New Zealand Schools: An Evaluation of Recent Reforms and Future Directions, Wellington: New Zealand Business Roundtable.

Shannon, P. (1991). Social Policy. Auckland: Oxford University Press. 
Shoemaker, P. (1991). Gatekeeping. London: Sage Publications.

Shuker, R. (1987). The One Best System? A Revisionist History of State Schooling in New Zealand. Palmerston North: The Dunmore Press Ltd.

Simon, J. (2000). Education Policy Change: Historical Perspectives. In Marshall, J., Coxon, E., Jenkins, K. and Jones, A. (Eds.), Politics, Policy, Pedagogy in Aotearoa/New Zealand (pp. 25-70). Palmerston North: The Dunmore Press Ltd.

Smith, G. (1988). Pikau: A Burden for One's Back. Access, 7, 34-44.

Smith, G. H. (1990). Taha Maori: Pakeha Capture. In Codd, J., Harker, R. and. Nash, R. (Eds.), Political issues In New Zealand Education (pp. 183-197). Palmerston North: The Dunmore Press Ltd.

Smith, G. (1990a). The Politics of reforming Maori Education: The transforming of Kura Kaupapa Maori. In Lauder, H. and Wylie, C. (Eds.), Towards Successful Schooling (pp. 73-88). London: The Falmer Press.

Smith, G. (1991). Note on: The Business Roundtable and the privatisation of Education: Individualism and the Attack on Maori. In Gordon, L. and Codd, J. (Eds.), Education Policy and the Changing Role of the State (pp. 99-106). Palmerston North: Massey University.

Smith, G. (1997). The development of kaupapa Maori: theory and praxis. Unpublished Ph.D., Auckland University, Auckland.

Snook, I. (1989). Educational reform in New Zealand: What is going on? Access: critical perspectives on education policy, 8 (2), 9-18.

Snook, I., Adams, P., Adams, R., Clark, J. and Codd, J. (1999). Educational Reforms in New Zealand: Is there any evidence of success? Palmerston North: Massey University.

Snook, I. (2000). Education \& Society in Aotearoa New Zealand. In Adams, P., Clark, J., Codd, J., O'Neill, A., Openshaw, R. and WaitereAng, H. (Eds.), Education \& Society in Aoteraroa New Zealand (pp. 911). Palmerston North: The Dunmore Press Ltd.

Souter, H. (2002). Average Net Circulation Figures of New Zealand Newspapers 1990-2001. Wellington: The New Zealand Press Association.

Sreberny, A. (2000). The Global and Local in International Communications. In Curran, J. and Gurevitch, M. (Eds.), Mass Media and Society (pp. 93-119). (3rd ed.). London: Arnold. 
Stewart-Harawira, M. (1997). The Impact of the State-Welfare Relationship on Whanau: Implications for Education. In Olssen, M. and Morris Matthews, K. (Eds.), Education Policy in New Zealand: The 1990s and Beyond (pp. 327-345). Palmerston North: The Dunmore Press Ltd.

Stirling, P. (2002, February 16). Twilight Zones. Listener, 19-23.

Sullivan, K. (1997). They've Opened Pandora's Box: Educational Reform, the New Right and Teachers' Ideologies. In Olssen, M. and Morris Matthews, K. (Eds.), Education Policy in New Zealand: The 1990s and Beyond (pp. 251-282). Palmerston North: The Dunmore Press Ltd.

Sullivan, K. (1999). Teacher Standards and Professionalism: Contested Perspectives in a Decade of Reform. Journal of Educational Studies, Special Edition, 34 (1).

Thrupp, M. and Smith, R. (1999). A Decade of ERO. In Thrupp, M. (Ed.), A Decade of Reform in New Zealand: Where to now? (pp. 186198). Waikato: Waikato University.

Thrupp, M. (1999). Schools Making A Difference: Let's Be Realistic! Buckingham: Open University Press.

Tidey, J. (2002). Well-Informed Sources. In McGregor, J. and Comrie, M. (Eds.), What's News? Reclaiming Journalism in New Zealand (pp. 72-80). Palmerston North: The Dunmore Press Ltd.

Trotter, C. (2002, January 19). Middle-Class Swingers. Listener, 14-15.

Tucker, J. (2001, July 15). Mediawatch (R. Brown, Director). Wellington: National Radio.

Tulloch, F. (2002, October 6). Mediawatch (R. Brown, Director). Wellington: National Radio.

Van Gompel, R., Van den Bulck, H. and Billereyst, D. (2002). News, Technology and the Paradoxes: A Case Study. In Newbold, C., BoydBarrett, O. and Van der Bulck, H. (Eds.), The Media Book (pp. 201206). London: Arnold.

Whitaker. (2002). Whitaker's 100 Year Almanack (136 ed.). London: A. and C. Black.

White, D. (1950). The Gatekeeper. A case study in the Selection of News. Reprint Political Science Dept. paper, 1984. 
Wilson, A., Houghton, R. and Piper, R. (1996). The introduction of bulk funding, including salaries of kindergartens. Dunedin: University of Otago Consulting Group.

Wylie, C. (1991). The Impact of Tomorrow's Schools in Primary Schools and Intermediates: 1991 Survey Report. Wellington: New Zealand Council for Educational Research.

Wylie, C. (1993). The impact of bulk funding on New Zealand kindergartens: Results of the second national survey. Wellington: New Zealand Council for Educational Research.

Wylie, C. (1997). At the centre of the web: The role of the New Zealand primary school principal within a decentralised education system. Wellington: New Zealand Council for Educational Research.

Wylie, C. (1997a). Self managing schools seven years on: what have we learnt? Wellington: New Zealand Council for Educational Research.

Wylie, C. (1998). Can Vouchers Deliver Better Education? A review of the literature with special reference to New Zealand. Wellington: New Zealand Council for Educational Research.

Wylie, C. (1999). Ten years On: How schools view educational reform. Wellington: New Zealand Council for Educational Research.

Wylie, C. (1999a). Is the Land of the Flightless Bird the Home of the Voucherless Voucher? New Zealand Journal of Educational Studies, 34 (1), 99-109.

Zavos, S. (2001, September 16). Mediawatch (A. Barker, Director). Wellington: National Radio.

\section{Major Policy Documents Referred to}

Department of Education (1987). The Curriculum Review: Report of the Committee to Review the Curriculum for Schools, Wellington:

Government Printer.

Department of Education (1988). Report on Post Compulsory Education and Training in New Zealand (The Hawke Report). Wellington: Government Printer.

Department of Education (1988). Report of the Early Childhood Care and Education Working Group (The Meade Report). Wellington: Government Printer.

Department of Education (1988). Administering for Excellence: Effective Administration in Education. Wellington: Government Printer. 
Department of Education (1988). Tomorrow's Schools: The Reform of Education Administration in New Zealand (The Picot Report). Wellington: Government Printer.

Ministry of Education (1990). Today's Schools: A Review of the Education Reform Implementation Process (Lough Report), Wellington: Ministry of Education.

Ministry of Education (1991). The National Curriculum of New Zealand, Wellington: Ministry of Education.

Ministry of Education (1993). The New Zealand Curriculum Framework, Wellington: Ministry of Education.

Ministry of Education (1993). Education for the Twenty-First Century: A Discussion Document, Wellington: Learning Media.

Ministry of Education (1994). Funding Growth in Tertiary Education and Training: Report of the Ministerial Consultative Group (The Todd Report), Wellington: Ministerial Consultative Group.

Ministry of Education (1994). Education for the Twenty-First Century, Wellington: Learning Media.

New Zealand Treasury (1984). Economic Management: Brief to the Incoming Government, Wellington: The New Zealand Treasury.

New Zealand Treasury (1987). Government Management: brief to the Incoming Government, Vol. II: Education Issues, Wellington: The New Zealand Treasury. 


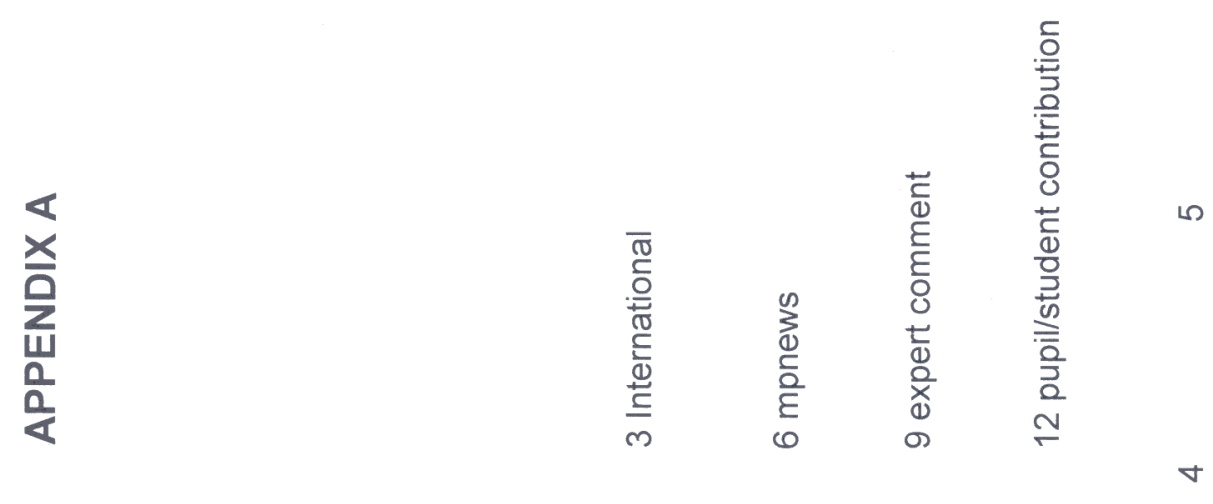

$\frac{\pi}{\frac{\pi}{0}}$

$\frac{\text { ㄷ }}{\text { 을 }}$

の $z$

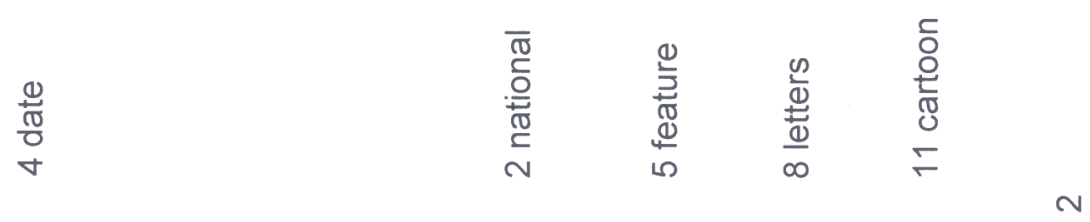

$m$

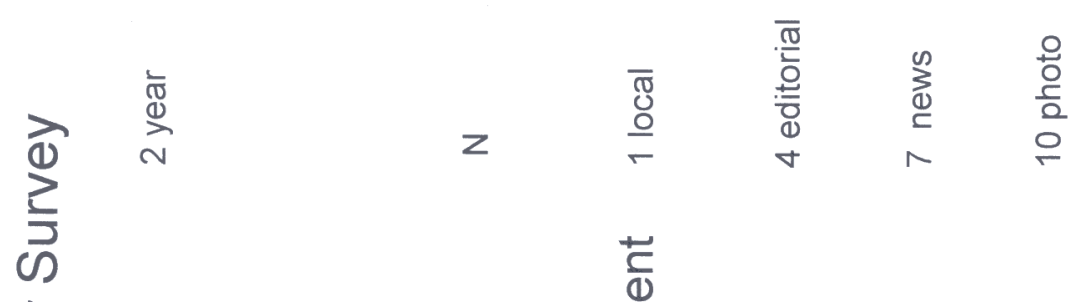

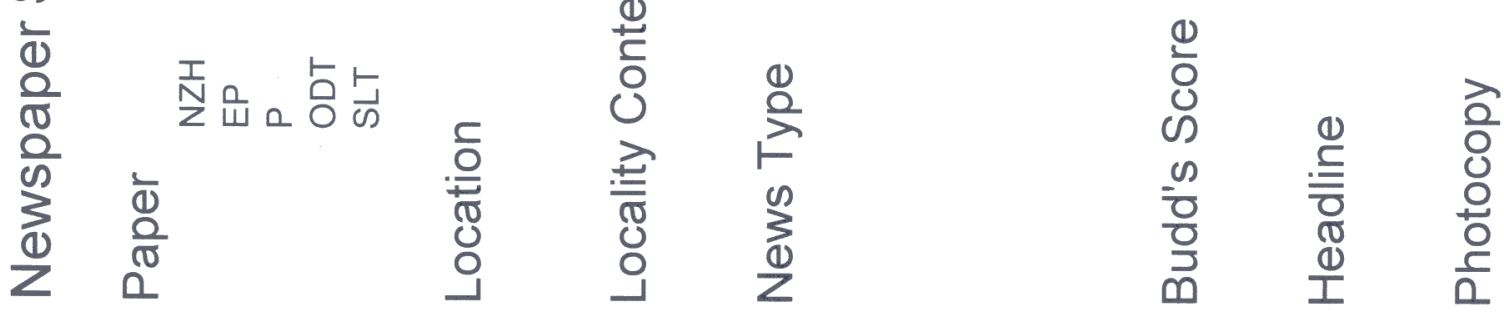




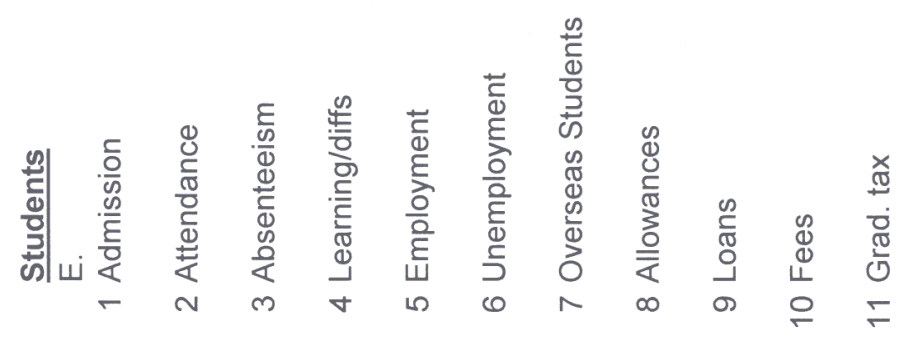

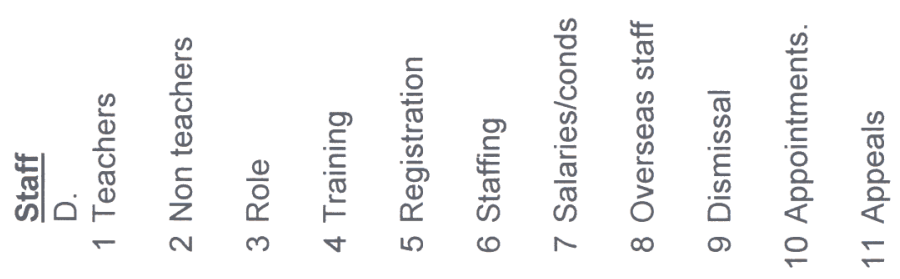

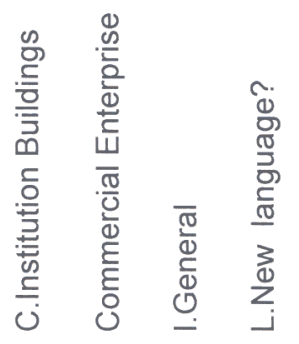

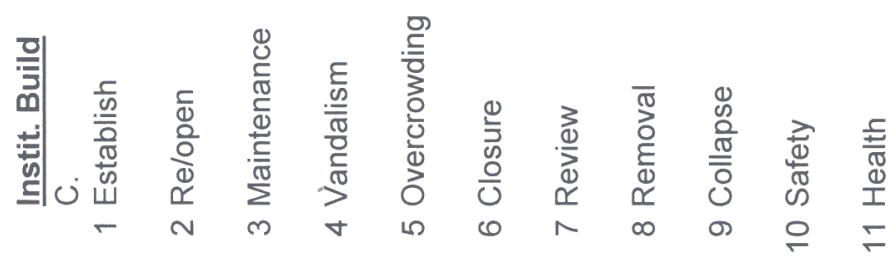

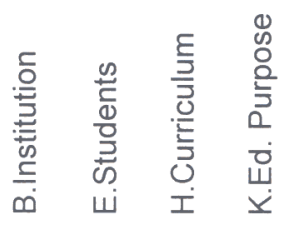

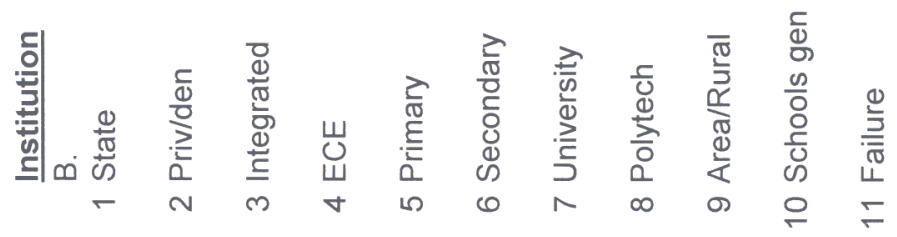

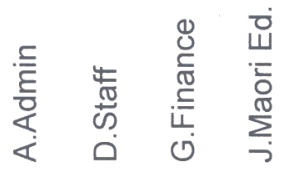

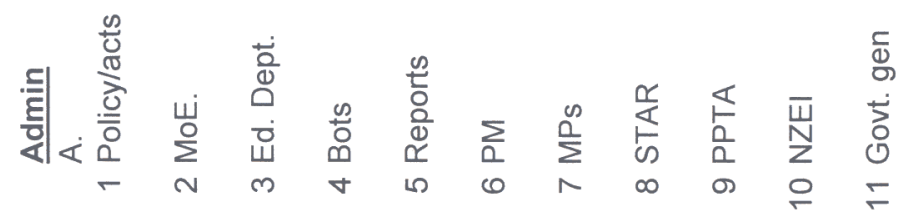

$\frac{\pi}{0}$
$\stackrel{0}{ \pm}$
0
0
$\frac{1}{0}$
$\stackrel{0}{0}$

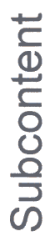




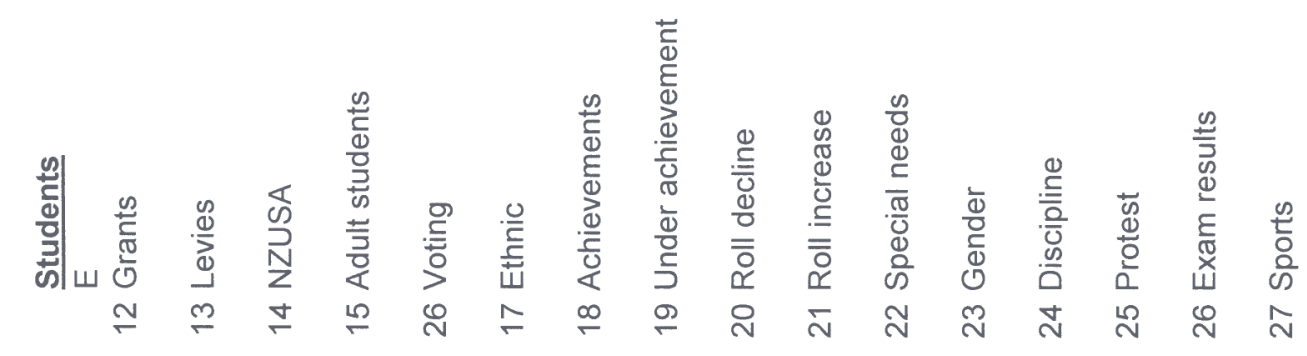

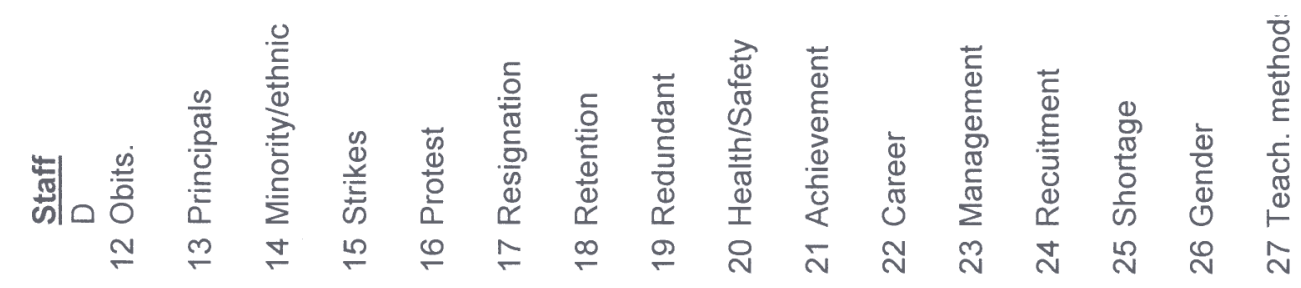

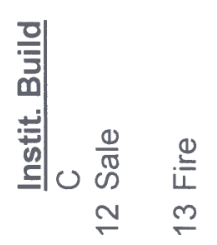

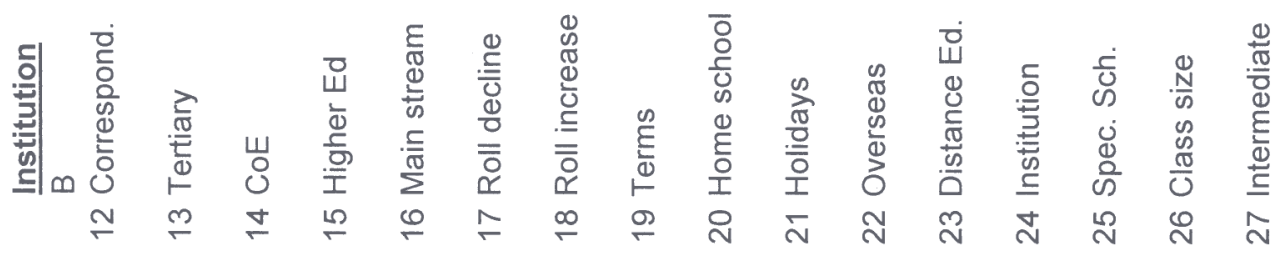

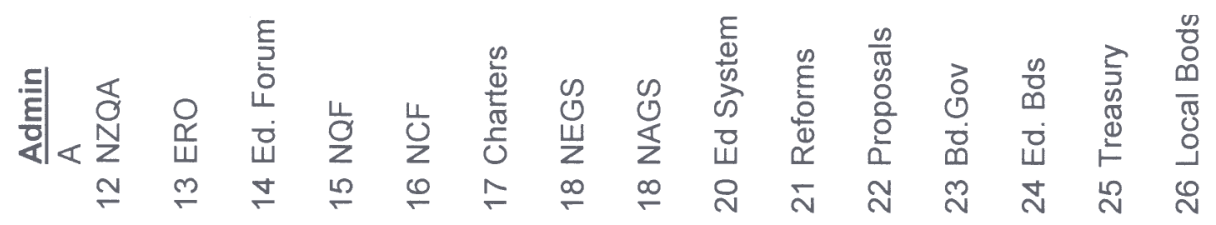

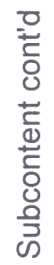




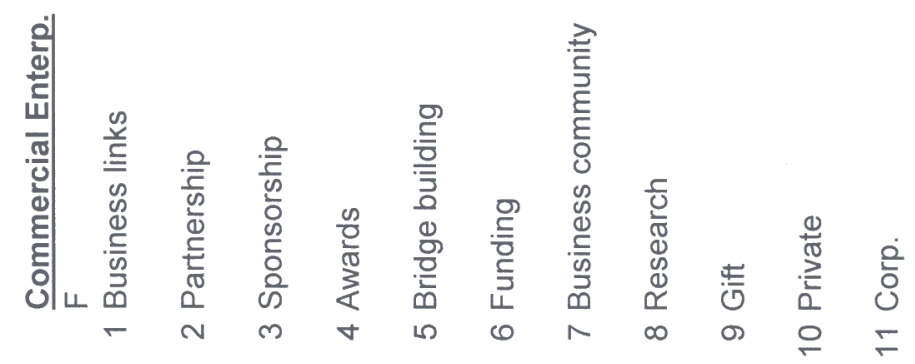

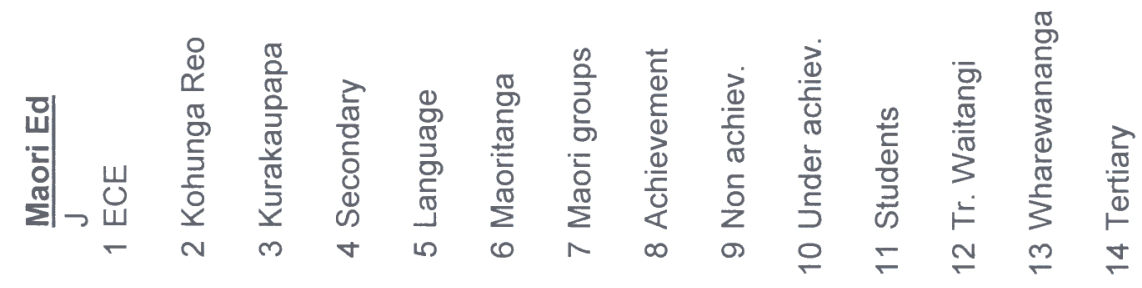

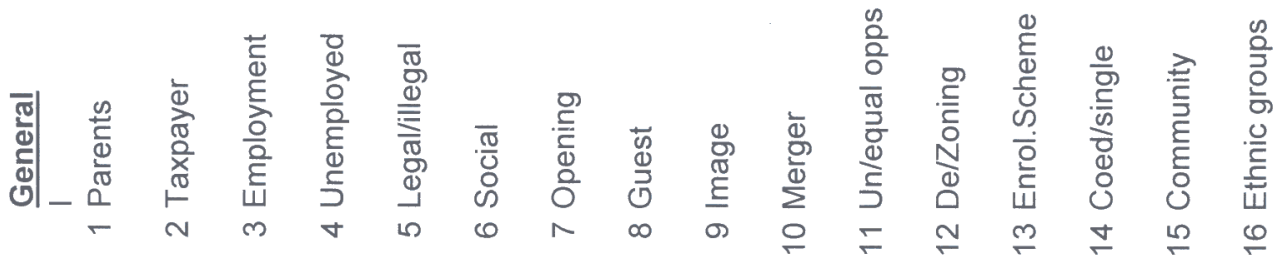

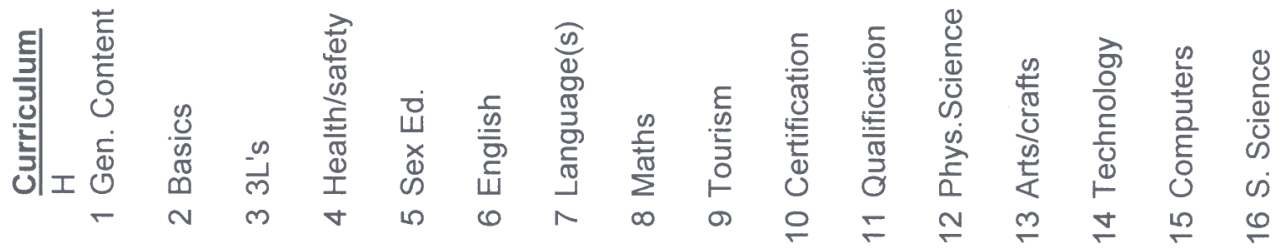

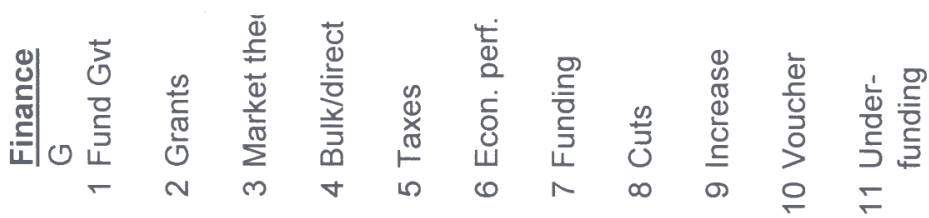

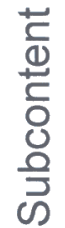




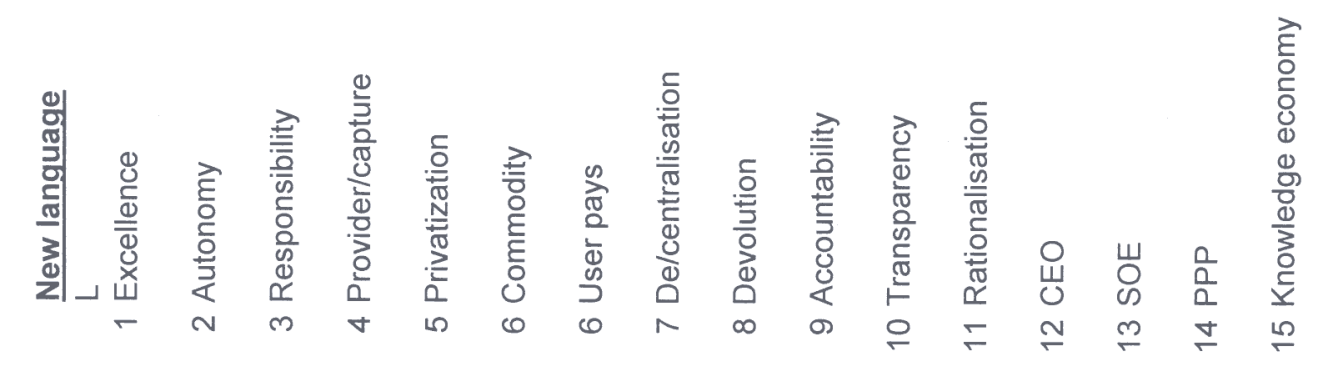

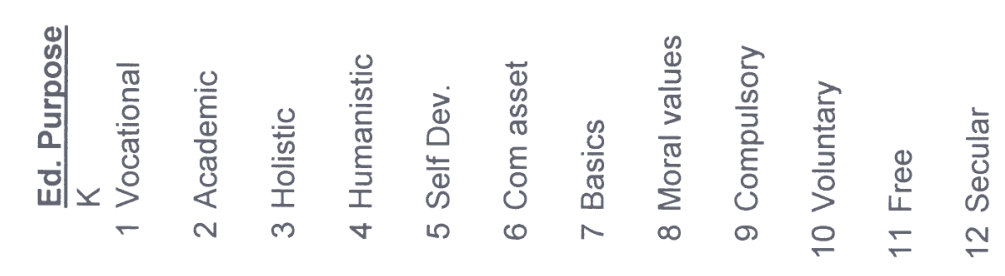

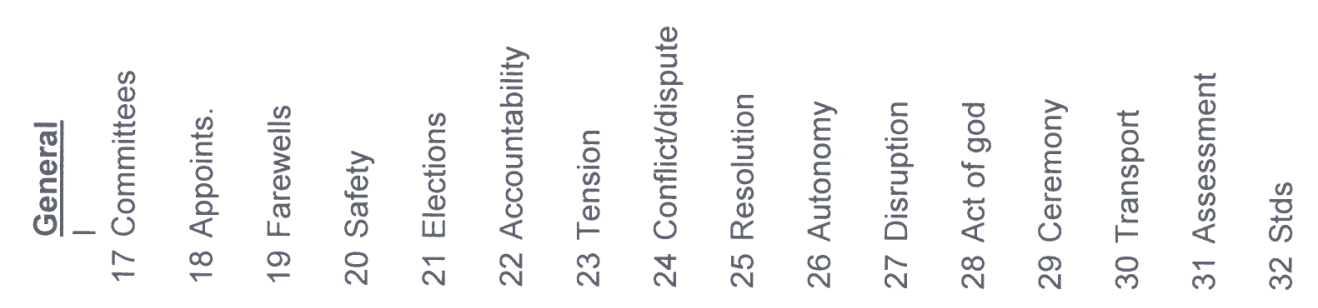

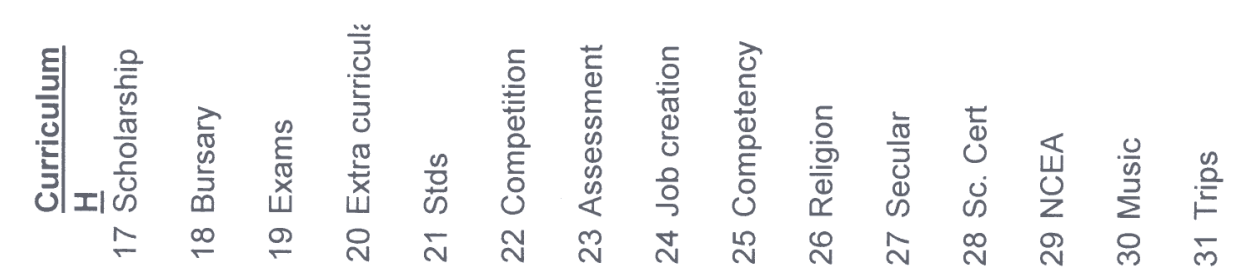

畜。

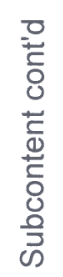




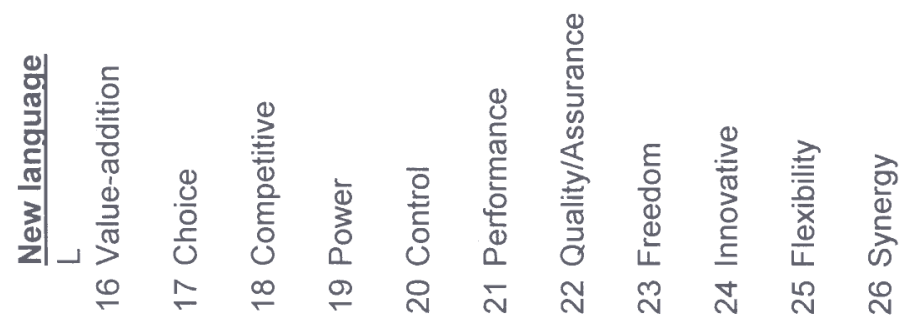

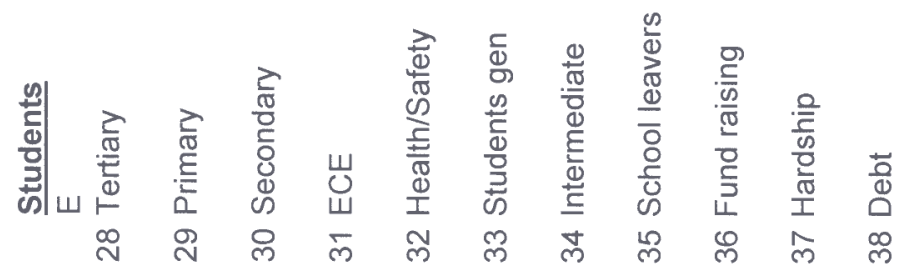




\section{APPENDIX B}

Table A.7.1: Summary by Newspapers of Story Contents and Subcontents with a Budd Score 4, giving their newstype and locality: 1988.

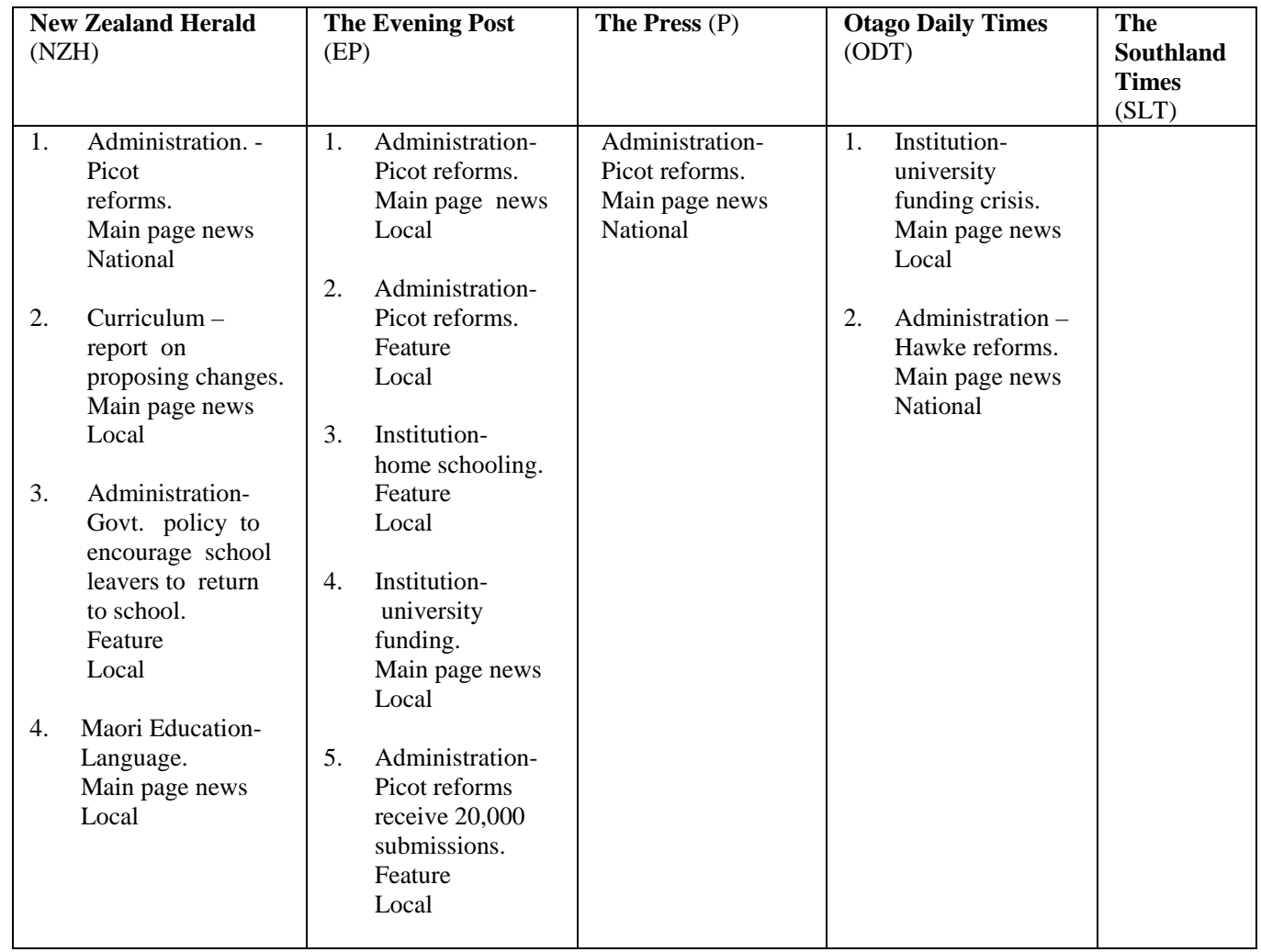




\section{APPENDIX C}

Table A.7.2: Summary by Newspapers of Story Contents and Subcontents with a Budd Score 4, giving their newstype and locality: 1989.

\begin{tabular}{|c|c|c|c|c|}
\hline $\begin{array}{l}\text { New Zealand Herald } \\
(\mathrm{NZH})\end{array}$ & $\begin{array}{l}\text { The Evening Post } \\
\text { (EP) }\end{array}$ & $\begin{array}{l}\text { The } \\
\text { Press (P) }\end{array}$ & $\begin{array}{l}\text { Otago Daily Times } \\
\text { (ODT) }\end{array}$ & $\begin{array}{l}\text { The Southland Times } \\
\text { (SLT) }\end{array}$ \\
\hline $\begin{array}{ll}\text { 1. } & \text { Students-health. } \\
\text { Main page news } \\
\text { International }\end{array}$ & $\begin{array}{l}\text { 1. Administration - } \\
\text { Education } \\
\text { system control. } \\
\text { Feature }\end{array}$ & & $\begin{array}{ll}\text { 1. } & \text { Students-protest. } \\
\text { Main page news } \\
\text { International }\end{array}$ & $\begin{array}{l}\text { 1. Staff - strike. } \\
\text { Feature } \\
\text { Local }\end{array}$ \\
\hline $\begin{array}{l}\text { 2. Administration- } \\
\text { Picot } \\
\text { reforms } \\
\text { News } \\
\text { Local }\end{array}$ & $\begin{array}{l}\text { Local } \\
\text { 2. Staff- redundancy } \\
\text { Main page news } \\
\text { Local }\end{array}$ & & $\begin{array}{l}\text { 2. Administration - } \\
\text { student } \\
\text { loans scheme. } \\
\text { Main page news } \\
\text { National }\end{array}$ & $\begin{array}{l}\text { 2. Administration- } \\
\text { charters, } \\
\text { Treaty of Waitangi. } \\
\text { Letter } \\
\text { Local }\end{array}$ \\
\hline $\begin{array}{l}\text { 3. Students - shun } \\
\text { new tertiary } \\
\text { courses. } \\
\text { Main page news }\end{array}$ & $\begin{array}{l}\text { 3. Finance- } \\
\text { underfunding of } \\
\text { schools. } \\
\text { Letter }\end{array}$ & & $\begin{array}{ll}1 & \begin{array}{l}\text { Student - } \\
\text { elections }\end{array} \\
& \text { Main page news } \\
& \text { Local }\end{array}$ & $\begin{array}{l}\text { 3. Students- protests. } \\
\text { Main page news } \\
\text { International }\end{array}$ \\
\hline $\begin{array}{l}\text { 4. Students- tertiary } \\
\text { loans. } \\
\text { Main page news } \\
\text { National }\end{array}$ & $\begin{array}{l}\text { 4. Finance- } \\
\text { underfunding of } \\
\text { schools. } \\
\text { Letter } \\
\text { Local }\end{array}$ & & $\begin{array}{l}\text { 4. Institution } \\
\text { Building- } \\
\text { tenders called. } \\
\text { Main page news } \\
\text { Local }\end{array}$ & $\begin{array}{l}\text { Main page news } \\
\text { International } \\
\text { 5. Students- protests. } \\
\text { Main page news } \\
\text { International }\end{array}$ \\
\hline $\begin{array}{ll}\text { 5. Students- } \\
\text { computers. } \\
\text { News } \\
\text { Local } \\
\text { 6. Staff- university } \\
\text { appointment. } \\
\text { News } \\
\text { Local }\end{array}$ & $\begin{array}{l}\text { 5. Student- } \\
\text { achievement } \\
\text { university exam } \\
\text { results. } \\
\text { News } \\
\text { Local }\end{array}$ & & $\begin{array}{l}\text { 5. Administration - } \\
\text { students' fees. } \\
\text { Main page news } \\
\text { National }\end{array}$ & $\begin{array}{l}\text { 6. Administration- } \\
\text { student funding. } \\
\text { Main page news } \\
\text { International }\end{array}$ \\
\hline
\end{tabular}




\section{APPENDIX D}

Table A.7.3: Summary of Newspapers of Story Contents and Subcontents with a Budd Score 4, giving their newstype and locality: 1990.

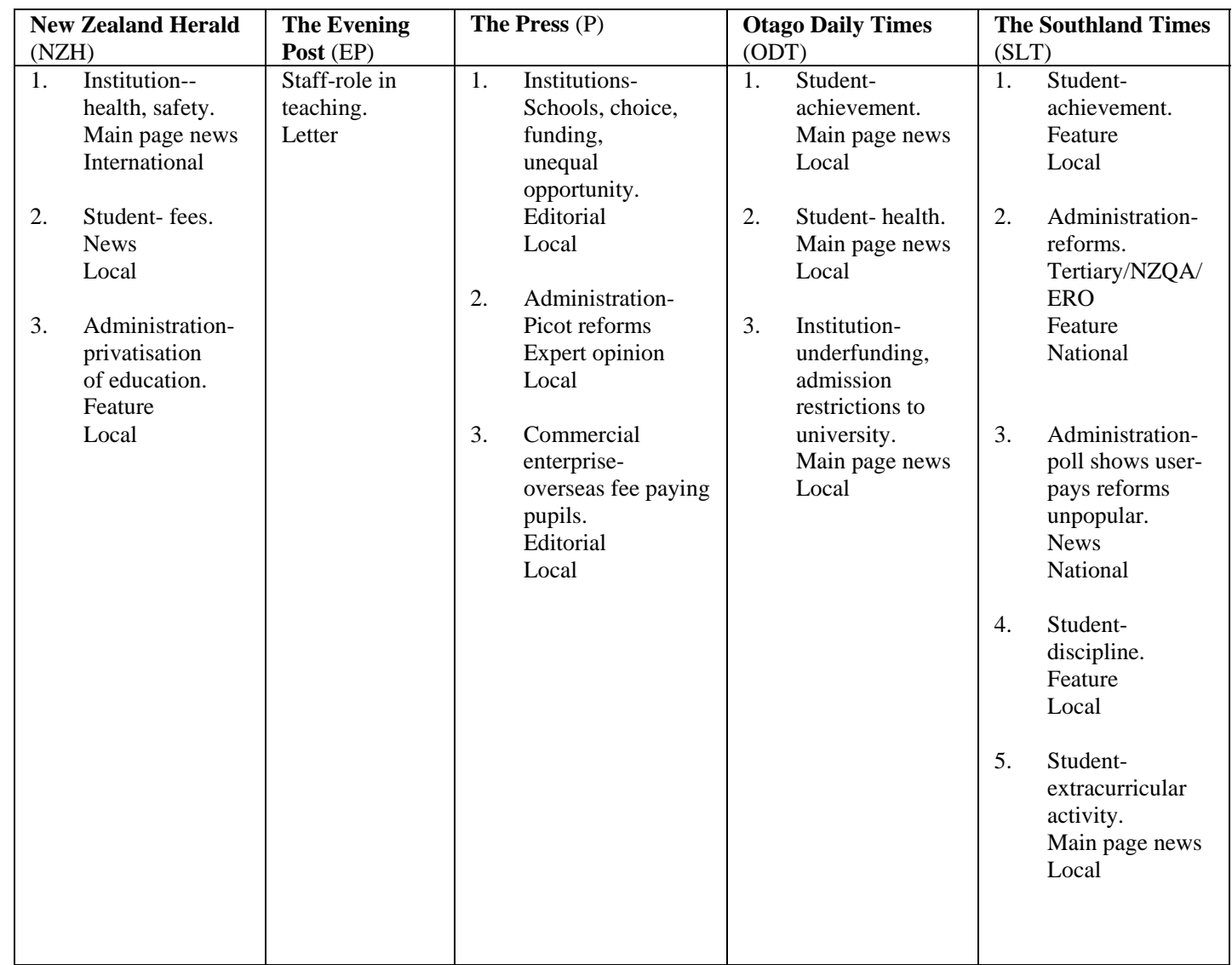




\section{APPENDIX E}

Table A.7.4: Summary by Newspapers of Story Contents and Subcontents with a Budd Score 4, giving their newstype and locality: 1991.

\begin{tabular}{|c|c|c|c|c|}
\hline $\begin{array}{l}\text { New Zealand Herald } \\
(\mathrm{NZH})\end{array}$ & $\begin{array}{l}\text { The Evening Post } \\
\text { (EP) }\end{array}$ & The Press (P) & $\begin{array}{l}\text { Otago Daily Times } \\
\text { (ODT) }\end{array}$ & $\begin{array}{l}\text { The Southland } \\
\text { Times (SLT) }\end{array}$ \\
\hline $\begin{array}{l}\text { 1. Staff- teachers' } \\
\text { salaries. } \\
\text { Main page news } \\
\text { Local }\end{array}$ & $\begin{array}{l}\text { Staff- health, } \\
\text { safety. } \\
\text { Main page news } \\
\text { Local }\end{array}$ & $\begin{array}{ll}1 . & \text { Institution- } \\
\text { zoning. } \\
\text { Expert comment } \\
\text { Local }\end{array}$ & $\begin{array}{l}\text { 1. Institution-EEC } \\
\text { opening. } \\
\text { Feature } \\
\text { Local }\end{array}$ & $\begin{array}{l}\text { Students- } \\
\text { benefit fraud. } \\
\text { Main page } \\
\text { news } \\
\text { Local }\end{array}$ \\
\hline $\begin{array}{l}\text { 2. Curriculum- } \\
\text { general } \\
\text { content. } \\
\text { Main page news } \\
\text { Local }\end{array}$ & & $\begin{array}{ll}\text { 2. } & \text { Administration } \\
\text { tertiary fees. } \\
\text { Main page news } \\
\text { National } \\
\\
\text { 3. } & \begin{array}{l}\text { Students- protest. } \\
\text { Main page news } \\
\text { International }\end{array}\end{array}$ & 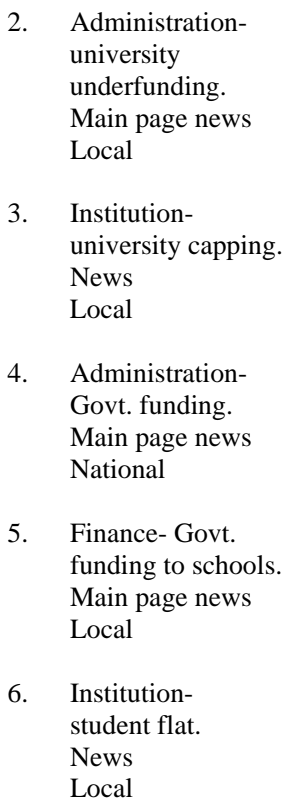 & $\begin{array}{l}\text { 2. Institution- } \\
\text { fire. } \\
\text { Main page } \\
\text { news } \\
\text { Local }\end{array}$ \\
\hline
\end{tabular}




\section{APPENDIX F}

Table A.7.5: Summary by Newspapers of Story Contents and Subcontents with a Budd Score 4, giving their newstype and locality: 1992.

\begin{tabular}{|c|c|c|c|c|}
\hline $\begin{array}{l}\text { New Zealand } \\
\text { Herald } \\
\text { (NZH) }\end{array}$ & $\begin{array}{l}\text { The Evening Post } \\
\text { (EP) }\end{array}$ & The Press $(\mathrm{P})$ & $\begin{array}{l}\text { Otago Daily Times } \\
\text { (ODT) }\end{array}$ & $\begin{array}{l}\text { The Southland } \\
\text { Times (SLT) }\end{array}$ \\
\hline $\begin{array}{l}\text { Institution } \\
\text { Building - } \\
\text { maintenance. } \\
\text { Main page news } \\
\text { Local }\end{array}$ & $\begin{array}{ll}\text { 1. } & \begin{array}{l}\text { Institution } \\
\text { Building- fire } \\
\text { prevention. } \\
\text { Letter } \\
\text { Local }\end{array} \\
\text { 2. } & \begin{array}{l}\text { Staff- control. } \\
\text { Feature } \\
\text { Local }\end{array} \\
\text { 3. } & \begin{array}{l}\text { Finance - bulk } \\
\text { funding. } \\
\text { Letter } \\
\text { Local }\end{array}\end{array}$ & $\begin{array}{ll}\text { 1. } & \text { Maori Education - } \\
\text { new opportunities. } \\
\text { Feature } \\
\text { National } \\
\text { 2. } \\
\text { Students- } \\
\text { allowances, } \\
\text { unequal } \\
\text { opportunities. } \\
\text { Expert comment } \\
\text { National } \\
\text { Curriculum- } \\
\text { unequal } \\
\text { opportunities. } \\
\text { Expert comment } \\
\text { Local } \\
\text { Administration- } \\
\text { N.Z. university role } \\
\text { threatened. } \\
\text { Expert comment } \\
\text { Local } \\
\text { Institution- NZ } \\
\text { university role in } \\
\text { conflict with } \\
\text { NZQA. } \\
\text { Expert comment } \\
\text { Local } \\
\text { Institution- NZ } \\
\text { university role in } \\
\text { conflict with } \\
\text { NZQA. } \\
\text { Expert comment } \\
\text { Local } \\
\text { 5. }\end{array}$ & $\begin{array}{ll}\text { 1. } & \begin{array}{l}\text { Students- } \\
\text { discipline. } \\
\text { Main page news } \\
\text { Local }\end{array} \\
\text { 2. } & \begin{array}{l}\text { Students- } \\
\text { discipline. } \\
\text { Main page } \\
\text { News } \\
\text { Local }\end{array} \\
\text { 3. } & \begin{array}{l}\text { Students- health, } \\
\text { safety. } \\
\text { Main page news } \\
\text { Local }\end{array} \\
\text { 4. } & \text { Staff- obituary to } \\
\text { Karl Popper. } \\
\text { Feature } \\
\text { Local } \\
\text { Administration - } \\
\text { 5tudent loan } \\
\text { repayment } \\
\text { proposal. } \\
\text { Main page news } \\
\text { Local }\end{array}$ & $\begin{array}{ll}\text { 1. } & \begin{array}{l}\text { Institution- } \\
\text { minority staff } \\
\text { appointments. } \\
\text { Feature } \\
\text { Local }\end{array} \\
\text { 2. } & \text { Institution- } \\
& \text { EEC } \\
\text { underfunding. } & \text { Main page } \\
\text { news } \\
\text { Local }\end{array}$ \\
\hline
\end{tabular}




\section{APPENDIX G}

Table A.7.6: Summary by Newspapers of Story Contents and Subcontents with a Budd Score 4, giving their newstype and locality: 1993.

\begin{tabular}{|c|c|c|c|c|}
\hline $\begin{array}{l}\text { New } \quad \text { Zealand } \\
\text { Herald } \\
(\mathrm{NZH})\end{array}$ & $\begin{array}{l}\text { The Evening Post } \\
\text { (EP) }\end{array}$ & The Press (P) & $\begin{array}{l}\text { Otago Daily Times } \\
\text { (ODT) }\end{array}$ & $\begin{array}{l}\text { The Southland Times } \\
\text { (SLT) }\end{array}$ \\
\hline $\begin{array}{ll}1 . & \text { Students- } \\
\text { ethnic minority } \\
\text { achievement. } \\
\text { Feature } \\
\text { Local }\end{array}$ & $\begin{array}{ll}1 . & \text { Students- } \\
\text { commercial } \\
\text { enterprise. } \\
\text { Main page } \\
\text { news } \\
\text { Local }\end{array}$ & $\begin{array}{l}\text { 1. Institution- EEC } \\
\text { inquiry. } \\
\text { Main page } \\
\text { news } \\
\text { Local }\end{array}$ & $\begin{array}{ll}1 . & \text { Institution- } \\
& \text { secondary school } \\
& \text { reunion. } \\
& \text { Main page news } \\
\text { Local }\end{array}$ & $\begin{array}{l}\text { 1. } \\
\text { Institution- } \\
\text { schools and } \\
\text { biculturalism. } \\
\text { Feature } \\
\text { Local }\end{array}$ \\
\hline $\begin{array}{l}\text { 2. Students- } \\
\text { extracurricular } \\
\text { activity. } \\
\text { News } \\
\text { Local }\end{array}$ & $\begin{array}{ll}\text { 2. } & \begin{array}{l}\text { Students- } \\
\text { discipline. } \\
\text { Letter } \\
\text { Local }\end{array} \\
\text { 3. } & \begin{array}{l}\text { Students- } \\
\text { conflict with } \\
\text { teachers. } \\
\text { Letter } \\
\text { Local }\end{array}\end{array}$ & $\begin{array}{ll}\text { 2. } & \begin{array}{l}\text { Institution- schools } \\
\text { value for money? } \\
\text { Feature } \\
\text { Local }\end{array} \\
\text { 3. } & \begin{array}{l}\text { Student- protest. } \\
\text { Cultural safety } \\
\text { Main page news } \\
\text { National }\end{array} \\
\text { 4. } & \begin{array}{l}\text { Finance- university } \\
\text { funding cuts. } \\
\text { Feature } \\
\text { Local }\end{array} \\
\text { 5. Administration - } \\
\text { seamless } \\
\text { education. } \\
\text { Expert comment } \\
\text { Feature } \\
\text { Local }\end{array}$ & $\begin{array}{ll}\text { 2. } & \begin{array}{l}\text { Finance- } \\
\text { university } \\
\text { funding. } \\
\text { Feature } \\
\text { Local }\end{array} \\
\text { 3. } & \begin{array}{l}\text { Administration. - } \\
\text { school funding } \\
\text { proposal. }\end{array} \\
\text { Main page news } \\
\text { Local }\end{array}$ & $\begin{array}{l}\text { 2. Staff- } \\
\text { achievement, } \\
\text { student prize } \\
\text { giving, image. } \\
\text { News } \\
\text { Local }\end{array}$ \\
\hline
\end{tabular}




\section{APPENDIX H}

Table A.7.7: Summary by Newspapers of Story Contents and Subcontents with a Budd Score 4, giving their newstype and locality: 1994.

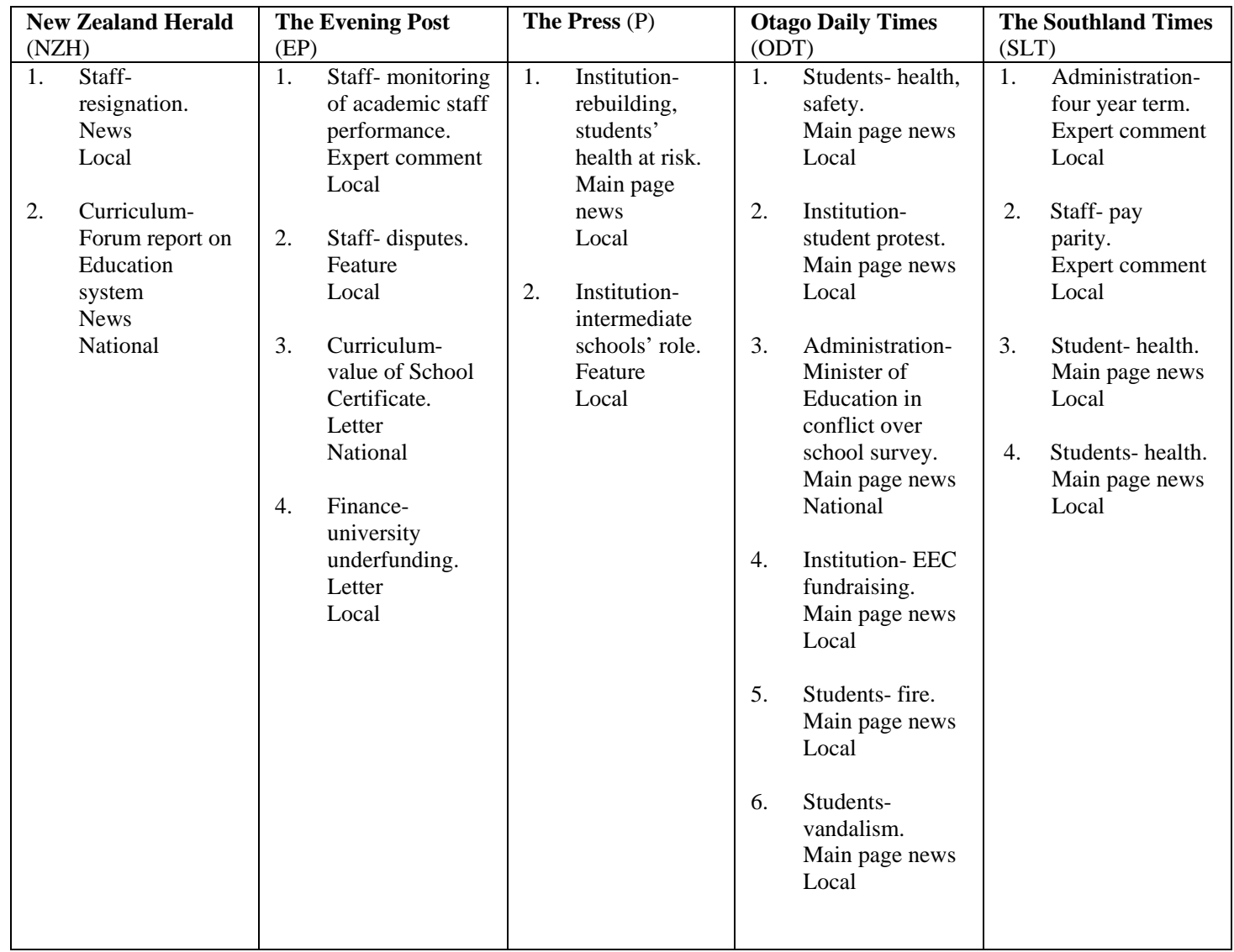




\section{APPENDIX I}

Table A.7.8: Summary by Newspapers of Story Contents and Subcontents with a Budd Score 4, giving their newstype and locality: 1995.

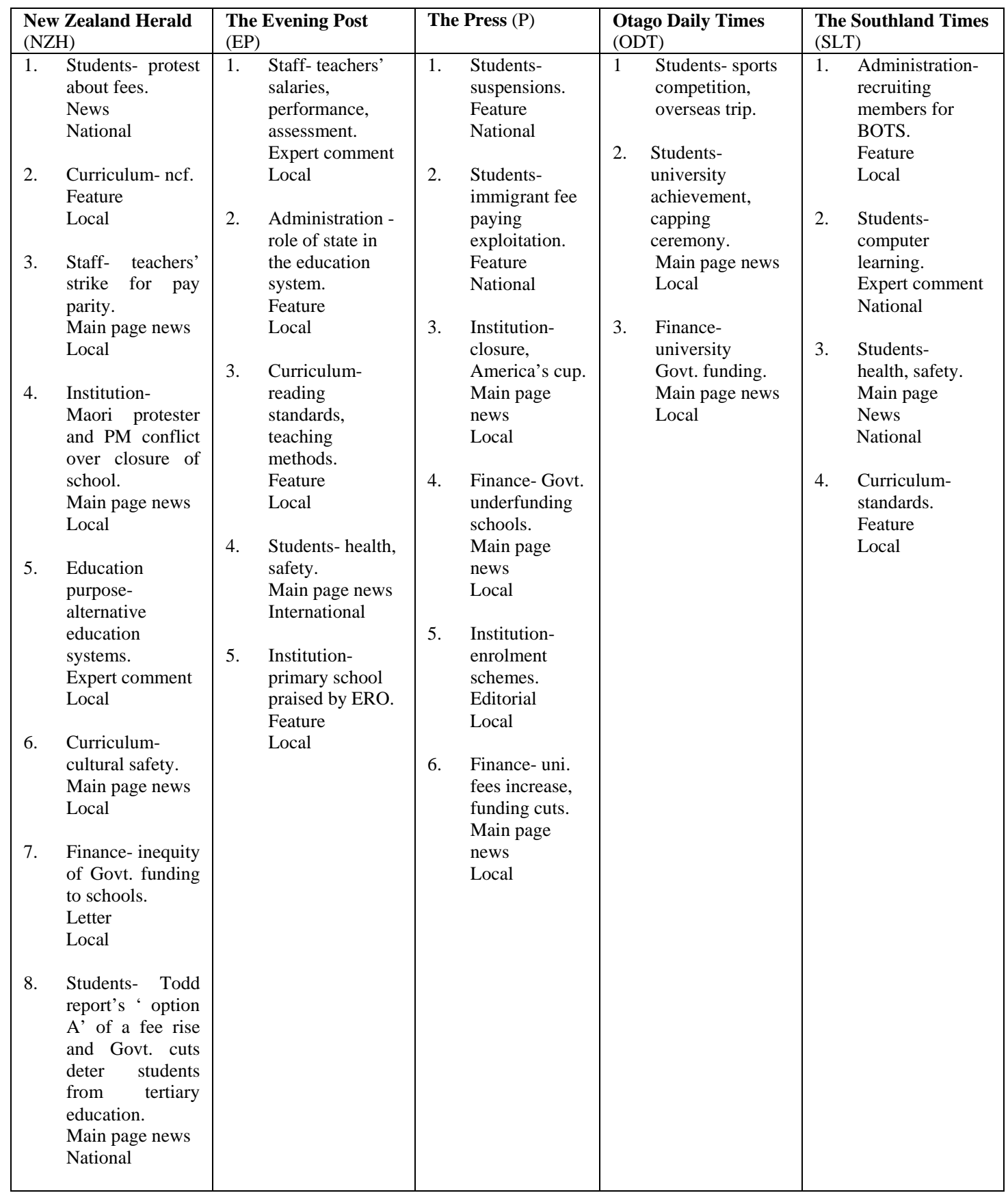


APPENDIX $\mathbf{J}$

Table A.7.9: Summary by Newspapers of Story Contents and Subcontents with a Budd Score 4, giving their newstype and locality: 1996.

\begin{tabular}{|c|c|c|c|c|}
\hline $\begin{array}{l}\text { New Zealand Herald } \\
(\mathrm{NZH})\end{array}$ & $\begin{array}{l}\text { The Evening Post } \\
\text { (EP) }\end{array}$ & The Press $(\mathrm{P})$ & $\begin{array}{l}\text { Otago Daily Times } \\
\text { (ODT) }\end{array}$ & $\begin{array}{l}\text { The Southland Times } \\
\text { (SLT) }\end{array}$ \\
\hline 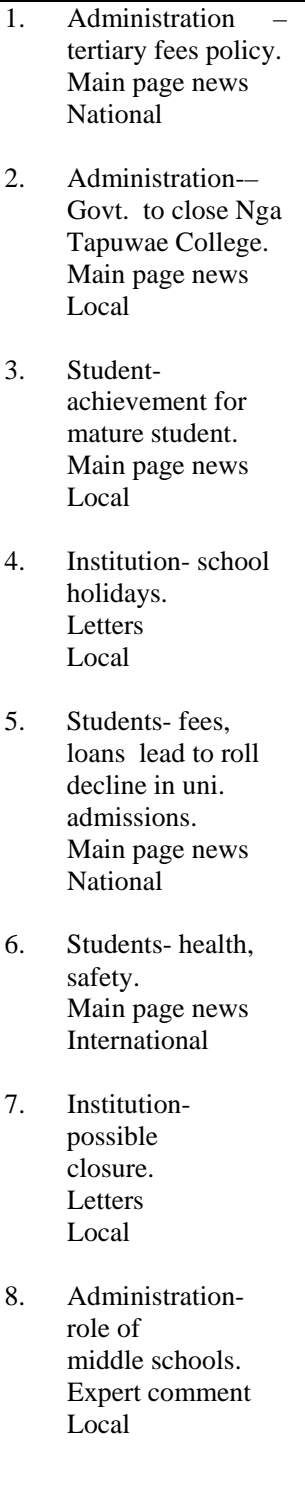 & $\begin{array}{ll}\text { 1. } & \begin{array}{l}\text { Finance- market } \\
\text { theory and } \\
\text { tertiary } \\
\text { education. } \\
\text { Expert comment } \\
\text { National }\end{array} \\
\text { 2. } & \begin{array}{l}\text { Students- } \\
\text { university life } \\
\text { style. }\end{array} \\
\text { Feature } \\
\text { Local } \\
\text { 3. } \\
\text { Education } \\
\text { purpose- role of } \\
\text { moral values. } \\
\text { Feature } \\
\text { Local } \\
\text { Institution- EEC } \\
\text { reforms. } \\
\text { Expert comment } \\
\text { Local }\end{array}$ & $\begin{array}{l}\text { 1. } \\
\text { Students- } \\
\text { health, } \\
\text { safety. } \\
\text { Main page } \\
\text { news } \\
\text { International } \\
\text { 2. } \\
\text { Commercial } \\
\text { Enterprise- } \\
\text { The } \\
\text { Business } \\
\text { Round table } \\
\text { critical of } \\
\text { the } \\
\text { Education } \\
\text { system. } \\
\text { Main page } \\
\text { news } \\
\text { Local } \\
\text { Admin- } \\
\text { General } \\
\text { election } \\
\text { policy on } \\
\text { Education. } \\
\text { Main page } \\
\text { news } \\
\text { Local } \\
\text { Institution- } \\
\text { Treasury's } \\
\text { response to } \\
\text { the Ministry } \\
\text { of } \\
\text { Education. } \\
\text { Feature } \\
\text { Local } \\
\text { Institution- } \\
\text { seamless } \\
\text { education } \\
\text { and } \\
\text { ownership of } \\
\text { thersities. } \\
\text { 4ocal } \\
\text { 5. }\end{array}$ & 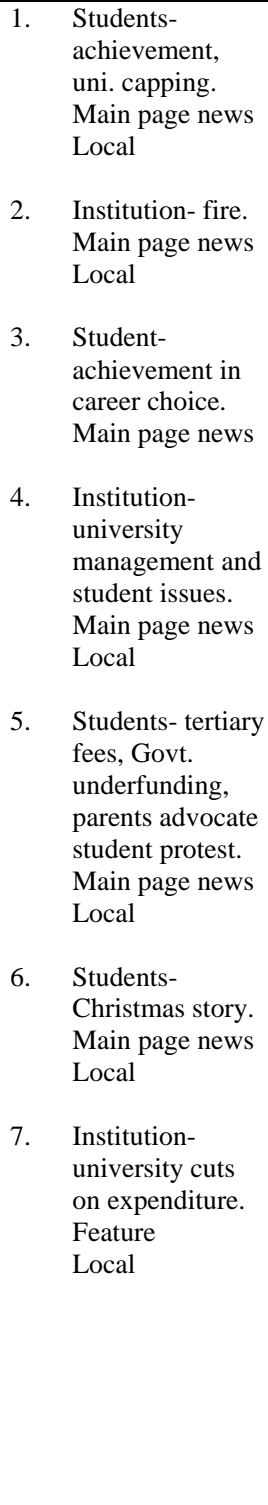 & $\begin{array}{ll}\text { 1. } & \begin{array}{l}\text { Administration - } \\
\text { Govt. proposal } \\
\text { on education } \\
\text { vouchers, equal } \\
\text { opportunity. } \\
\text { Expert comment } \\
\text { Local }\end{array} \\
\text { 2. } & \begin{array}{l}\text { Finance- Govt. } \\
\text { cutbacks on local } \\
\text { polytechnic. } \\
\text { Feature } \\
\text { Local }\end{array} \\
\text { 3. } & \begin{array}{l}\text { General-school } \\
\text { reunions. } \\
\text { Feature } \\
\text { Local }\end{array}\end{array}$ \\
\hline
\end{tabular}




\section{APPENDIX K}

Table A.7.10: Summary by Newspapers of Story Contents and Subcontents with a Budd Score 4, giving their newstype and locality: 1997.

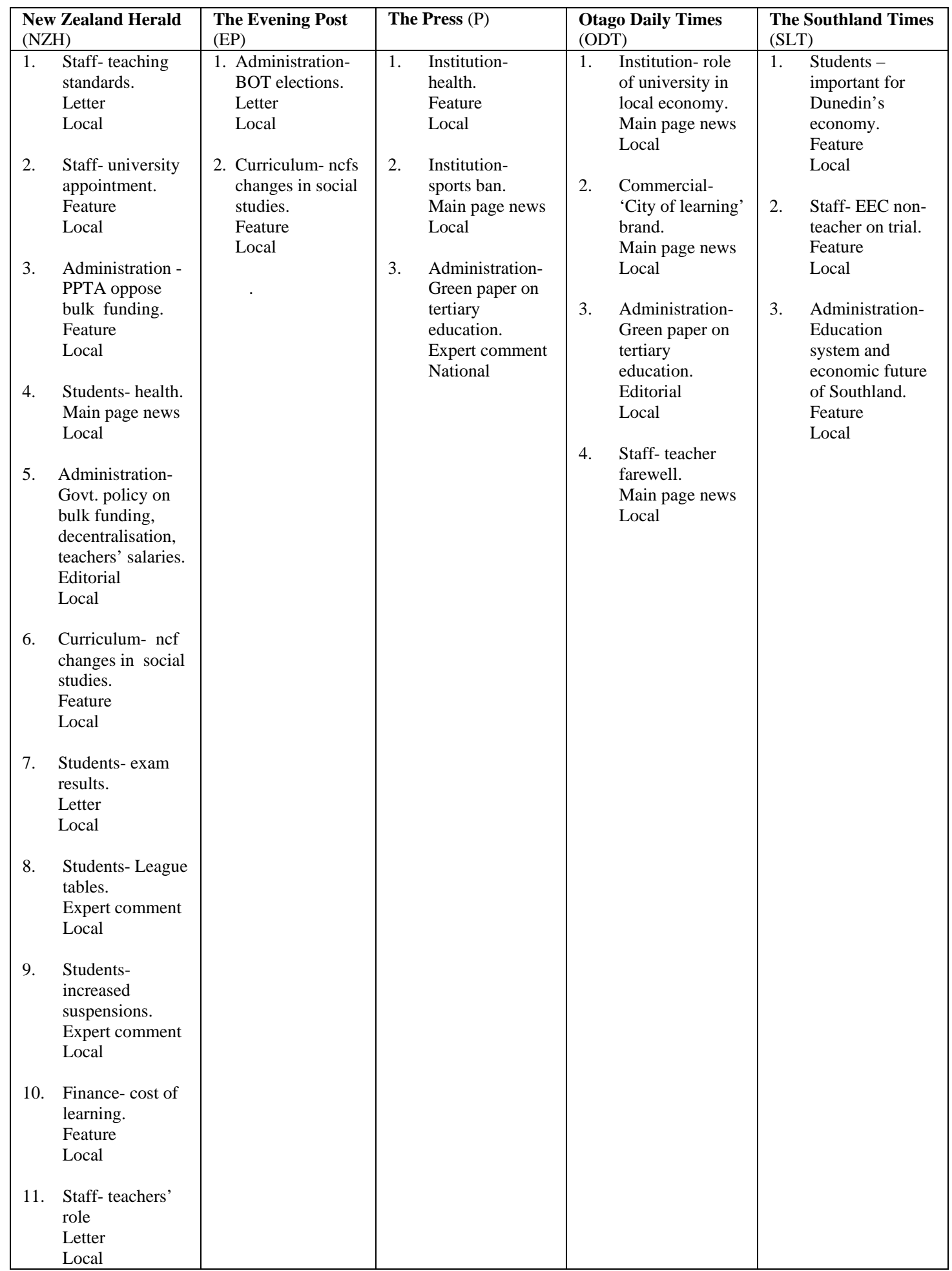




\section{APPENDIX L}

Table A.7.11: Summary by Newspapers of Story Contents and Subcontents with a Budd Score 4, giving their newstype and locality: 1998.

\begin{tabular}{|c|c|c|c|c|}
\hline $\begin{array}{l}\text { New Zealand Herald } \\
(\mathrm{NZH})\end{array}$ & $\begin{array}{l}\text { The Evening } \\
\text { Post (EP) }\end{array}$ & The Press $(\mathrm{P})$ & $\begin{array}{l}\text { Otago Daily Times } \\
\text { (ODT) }\end{array}$ & $\begin{array}{l}\text { The Southland Times } \\
\text { (SLT) }\end{array}$ \\
\hline $\begin{array}{l}\text { 1. Finance- Govt. } \\
\text { cuts, underfunding } \\
\text { lead to problems of } \\
\text { staff retention. } \\
\text { News } \\
\text { Local }\end{array}$ & $\begin{array}{l}\text { Student- } \\
\text { unemployment } \\
\text { benefit } \\
\text { compared to } \\
\text { student } \\
\text { allowance. } \\
\text { Letter }\end{array}$ & $\begin{array}{ll}\text { 1. } & \begin{array}{l}\text { Institution- } \\
\text { Open Day at local }\end{array} \\
\text { polytechnic } \\
\text { Feature } \\
\text { Local } \\
\text { 2. Administration- }\end{array}$ & $\begin{array}{l}\text { Staff- salaries, } \\
\text { conditions cause } \\
\text { resignations and } \\
\text { teacher shortages } \\
\text { Expert comment } \\
\text { Local }\end{array}$ & $\begin{array}{ll}\text { 1. } & \text { Curriculum- } \\
\text { introduction of } \\
\text { sports scheme as } \\
\text { a career. } \\
\text { Main page news } \\
\text { Local }\end{array}$ \\
\hline $\begin{array}{l}\text { 2. Administration- } \\
\text { ERO reviews now } \\
\text { welcome. } \\
\text { Feature } \\
\text { Local }\end{array}$ & Local & $\begin{array}{l}\text { PPTA CEO } \\
\text { opposes dismissal } \\
\text { Main page news } \\
\text { Local }\end{array}$ & $\begin{array}{l}\text { 2. Students- } \\
\text { fostering high } \\
\text { achievement. } \\
\text { Expert comment } \\
\text { Local }\end{array}$ & $\begin{array}{l}\text { 2. Students- choral } \\
\text { festival. } \\
\text { Feature } \\
\text { Local }\end{array}$ \\
\hline $\begin{array}{l}\text { 3. Finance- } \\
\text { self-managed } \\
\text { schools not the } \\
\text { answer. } \\
\text { Expert comment } \\
\text { Local }\end{array}$ & & & & $\begin{array}{l}\text { Institution- } \\
\text { Steiner school } \\
\text { philosophy and } \\
\text { aims in } \\
\text { education. } \\
\text { Feature } \\
\text { Local }\end{array}$ \\
\hline $\begin{array}{l}\text { 4. Maori Education- } \\
\text { developing } \\
\text { alternative } \\
\text { education under } \\
\text { Tomorrows' } \\
\text { schools. } \\
\text { Expert comment } \\
\text { Local }\end{array}$ & & & & \\
\hline $\begin{array}{l}\text { 5. Students- } \\
\text { achievement. } \\
\text { Main page news } \\
\text { Local }\end{array}$ & & & & \\
\hline $\begin{array}{l}\text { 6. Institution } \\
\text { Buildings- } \\
\text { EEC protest about } \\
\text { Ministry of } \\
\text { Education } \\
\text { removing } \\
\text { classrooms. } \\
\text { Main page news } \\
\text { Local }\end{array}$ & & & & \\
\hline $\begin{array}{l}\text { 7. Student-EEC's } \\
\text { Christmas play. } \\
\text { Main page news } \\
\text { Local }\end{array}$ & & & & \\
\hline
\end{tabular}




\section{APPENDIX M}

Table A.7.12: Summary by Newspapers of Story Contents and Subcontents with a Budd Score 4, giving their newstype and locality: 1999.

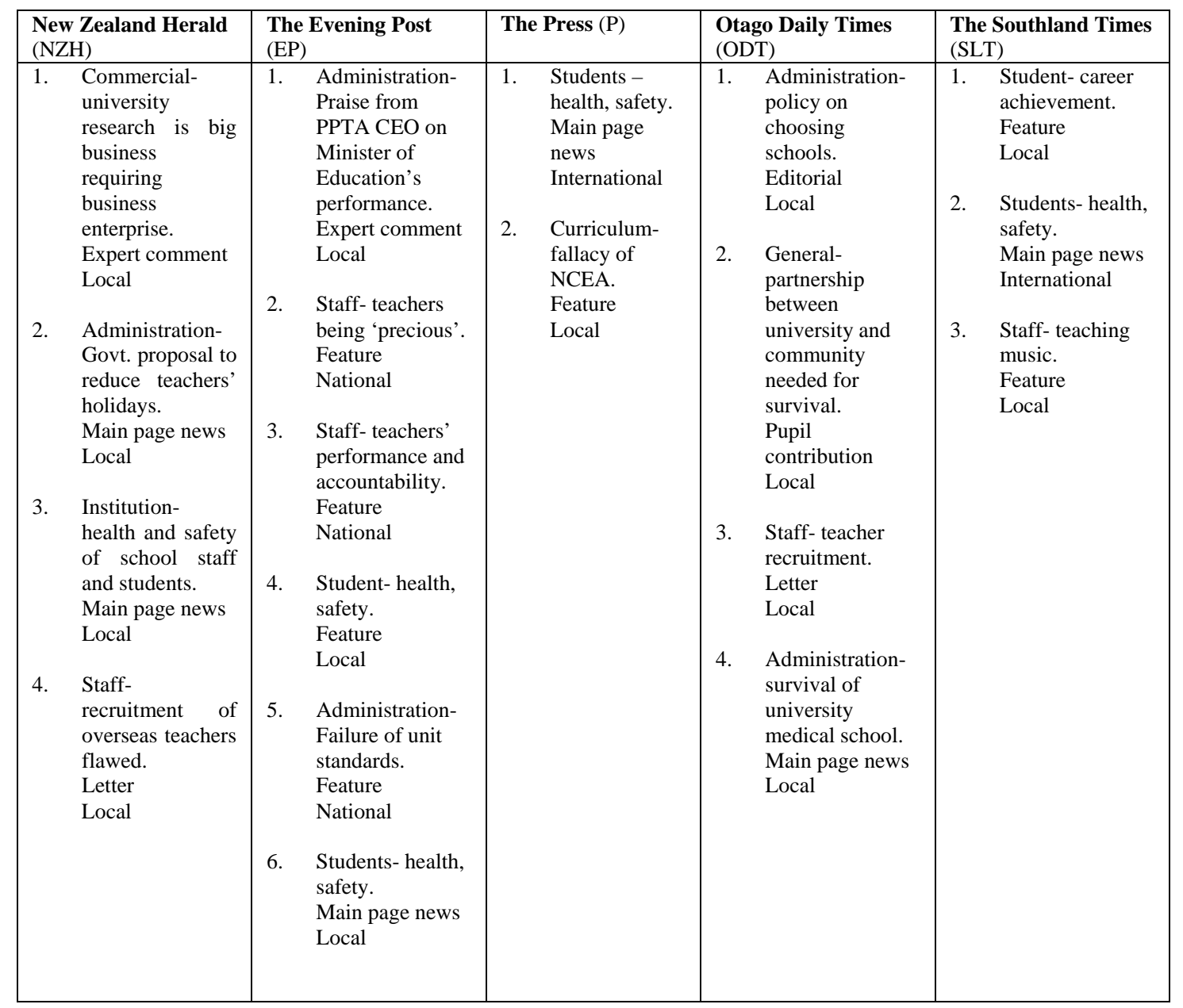




\section{APPENDIX N}

Table A.7.13: Summary by Newspapers of Story Contents and Subcontents with a Budd Score 5, giving their newstype and locality: 1988-1992.

\begin{tabular}{|c|c|c|c|c|c|}
\hline $\begin{array}{l}\mathbf{Y} \\
\mathbf{e} \\
\mathbf{a} \\
\mathbf{r}\end{array}$ & $\begin{array}{l}\text { New Zealand Herald } \\
\text { (NZH) }\end{array}$ & $\begin{array}{l}\text { The Evening } \\
\text { Post (EP) }\end{array}$ & The Press (P) & $\begin{array}{l}\text { Otago Daily } \\
\text { Times (ODT) }\end{array}$ & $\begin{array}{l}\text { The Southland } \\
\text { Times (SLT) }\end{array}$ \\
\hline $\begin{array}{l}1 \\
9 \\
8 \\
8\end{array}$ & $\begin{array}{ll}1 . & \text { Administration- } \\
& \text { Hawke Report } \\
& \text { Feature } \\
& \text { National } \\
& \\
2 . & \begin{array}{l}\text { Curriculum- } \\
\text { science. } \\
\text { Feature } \\
\text { Local }\end{array}\end{array}$ & $\begin{array}{l}\text { Administration- } \\
\text { Picot Report } \\
\text { Main page news } \\
\text { Local }\end{array}$ & & 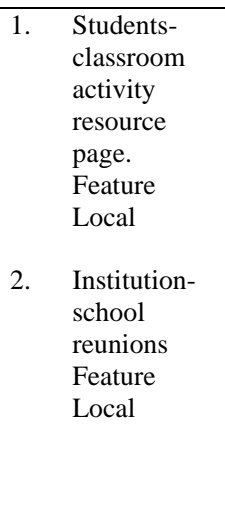 & $\begin{array}{ll}\text { 1. } & \begin{array}{l}\text { Student- thank } \\
\text { you to staff. } \\
\text { Pupil /Student } \\
\text { contribution } \\
\text { Local }\end{array} \\
\text { 2. } & \begin{array}{l}\text { Commercial } \\
\text { sponsorship } \\
\text { of schools. } \\
\text { Feature } \\
\text { Local }\end{array} \\
\text { 3. } & \begin{array}{l}\text { General- } \\
\text { Link courses } \\
\text { Feature } \\
\text { Local }\end{array}\end{array}$ \\
\hline $\begin{array}{l}1 \\
9 \\
8 \\
9\end{array}$ & $\begin{array}{l}\text { Administration- } \\
\text { Picot reforms. } \\
\text { Editorial } \\
\text { Local }\end{array}$ & & $\begin{array}{l}\text { Student - } \\
\text { achievement, } \\
\text { university exam. } \\
\text { results. } \\
\text { News } \\
\text { Local }\end{array}$ & & \\
\hline $\begin{array}{l}1 \\
9 \\
9 \\
0\end{array}$ & $\begin{array}{l}\text { Student - health. } \\
\text { Main page news } \\
\text { International }\end{array}$ & & & & \\
\hline $\begin{array}{l}1 \\
9 \\
9 \\
1\end{array}$ & & & $\begin{array}{ll}1 . & \begin{array}{l}\text { Administration } \\
\text { School reforms } \\
\text { and funding } \\
\text { crisis. }\end{array} \\
& \text { Expert } \\
\text { opinion } & \text { Feature } \\
& \text { Local } \\
& \\
\text { 2. Student- } & \text { achievement } \\
\text { secondary } \\
\text { school prizes. } \\
\text { News } \\
\text { Local }\end{array}$ & $\begin{array}{l}\text { Institution- } \\
\text { emphasis on } \\
\text { academic success } \\
\text { at Otago Boys’ } \\
\text { High School. } \\
\text { Feature } \\
\text { Local }\end{array}$ & \\
\hline $\begin{array}{l}1 \\
9 \\
9 \\
2\end{array}$ & & & $\begin{array}{l}\text { Student- visit } \\
\text { Feature } \\
\text { Local }\end{array}$ & $\begin{array}{ll}1 . & \begin{array}{l}\text { Student- } \\
\text { achievement } \\
\text { university } \\
\text { exam }\end{array} \\
\text { results. } \\
\\
\text { Feature } \\
\text { Local } \\
\text { 2. } \\
\text { Admin. - } \\
\text { BOT } \\
\text { election } \\
\text { results. } \\
\text { News } \\
\text { Local }\end{array}$ & \\
\hline
\end{tabular}




\section{APPENDIX O}

Table A.7.14: Summary by Newspapers of Story Contents and Subcontents with a Budd Score 5, giving their newstype: 1993-1999.

\begin{tabular}{|c|c|c|c|c|c|}
\hline \begin{tabular}{l|}
$\mathbf{Y}$ \\
$\mathbf{e}$ \\
$\mathbf{a}$ \\
$\mathbf{r}$
\end{tabular} & $\begin{array}{l}\text { New Zealand } \\
\text { Herald } \\
\text { (NZH) }\end{array}$ & $\begin{array}{l}\text { The Evening Post } \\
\text { (EP) }\end{array}$ & The Press $(\mathrm{P})$ & $\begin{array}{l}\text { Otago Daily Times } \\
\text { (ODT) }\end{array}$ & $\begin{array}{l}\text { The Southland Times } \\
\text { (SLT) }\end{array}$ \\
\hline \begin{tabular}{l|}
1 \\
9 \\
9 \\
3 \\
\end{tabular} & & & & . & \\
\hline \begin{tabular}{l|}
1 \\
9 \\
9 \\
4
\end{tabular} & & $\begin{array}{l}\text { Students- sport. } \\
\text { Feature } \\
\text { Local }\end{array}$ & $\begin{array}{l}\text { Administration- } \\
\text { school reforms. } \\
\text { Com. enterprise } \\
\text { Feature } \\
\text { Local }\end{array}$ & & \\
\hline \begin{tabular}{l|}
1 \\
9 \\
9 \\
5
\end{tabular} & & $\begin{array}{l}\text { Institution-choice } \\
\text { of schools. } \\
\text { Feature } \\
\text { Local }\end{array}$ & & & $\begin{array}{ll}1 . & \text { Student - health. } \\
& \text { Feature } \\
& \text { Local } \\
& \\
2 . & \text { Commercial - } \\
\text { awards to tertiary } \\
\text { students. } \\
\text { Feature } \\
\text { Local }\end{array}$ \\
\hline \begin{tabular}{l|}
1 \\
9 \\
9 \\
6 \\
\end{tabular} & & & & & \\
\hline \begin{tabular}{l|}
1 \\
9 \\
9 \\
7
\end{tabular} & & $\begin{array}{l}\text { Student- health. } \\
\text { Feature } \\
\text { Local }\end{array}$ & $\begin{array}{l}\text { Institution- } \\
\text { computers in } \\
\text { schools. } \\
\text { Feature } \\
\text { Local }\end{array}$ & & \\
\hline \begin{tabular}{l|}
1 \\
9 \\
9 \\
8
\end{tabular} & & & & & $\begin{array}{l}\text { Students- Kingswell } \\
\text { High School closure. } \\
\text { Feature } \\
\text { Local }\end{array}$ \\
\hline \begin{tabular}{l|}
1 \\
9 \\
9 \\
9
\end{tabular} & & $\begin{array}{ll}1 . & \begin{array}{l}\text { Student - } \\
\text { health. }\end{array} \\
& \text { Feature } \\
& \text { Local } \\
& \\
2 . & \text { Institution- } \\
& \text { university } \\
\text { centennial. } & \text { Feature } \\
& \text { Local }\end{array}$ & $\begin{array}{l}\text { Student- } \\
\text { achievement, } \\
\text { secondary } \\
\text { student. } \\
\text { News } \\
\text { Local }\end{array}$ & $\begin{array}{ll}\text { 1. } & \begin{array}{l}\text { Student- } \\
\text { university life. } \\
\text { Feature } \\
\text { Local }\end{array} \\
\text { 2. } & \begin{array}{l}\text { Student } \\
\text { achievement, } \\
\text { uni. capping. } \\
\text { News } \\
\text { Local }\end{array} \\
\text { 3. } & \begin{array}{l}\text { Student- } \\
\text { opinion about } \\
\text { the General } \\
\text { elections. } \\
\text { Pupil } \\
\text { contribution } \\
\text { Feature } \\
\text { Local }\end{array}\end{array}$ & \\
\hline
\end{tabular}

